\author{
UNIVERSIDADE DE SÃO PAULO \\ FACULDADE DE EDUCAÇÃO, INSTITUTO DE FÍSICA, INSTITUTO DE \\ QUÍMICA E INSTITUTO DE BIOCIÊNCIAS
}

Propósitos epistêmicos para a promoção da argumentação em aulas investigativas de física

Arthur Tadeu Ferraz

SÃO PAULO

2015 


\author{
Arthur Tadeu Ferraz
}

\title{
Propósitos epistêmicos para a promoção da argumentação em aulas investigativas de física
}

Dissertação apresentada ao Programa de Pós-Graduação Interunidades em Ensino de Ciências da Universidade de São Paulo para a obtenção do título de mestre em ensino de ciências, modalidade Física.

\section{Área de Concentração}

Ensino de Ciências e Matemática

Orientadora

Prof $^{\underline{a}}$ Drª Lúcia Helena Sasseron

SÃO PAULO 
Autorizo a reprodução e divulgação total ou parcial deste trabalho, por qualquer meio convencional ou eletrônico, para fins de estudo e pesquisa, desde que citada a fonte.

\section{FICHA CATALOGRÁFICA \\ Preparada pelo Serviço de Biblioteca e Informação do Instituto de Física da Universidade de São Paulo}

Ferraz, Arthur Tadeu

Propósitos epistêmicos para a promoção da argumentação em aulas investigativas de física. São Paulo, 2015.

Dissertação (Mestrado) - Universidade de São Paulo.

Faculdade de Educação, Instituto de Física, Instituto de Química e Instituto de Biociências.

Orientador: Profa. Dra. Lúcia Helena Sasseron

Área de Concentração: Ensino de Ciências e Matemática.

Unitermos: 1. Física - Estudo e ensino; 2. Argumentação; 3. Ensino médio; 4. Práticas científicas; 5 . Ensino por investigação. 


\section{AGRADECIMENTOS}

Finalizar esta dissertação representa o fechamento de um ciclo. É um momento de encerramento e também de reflexão. Por isso, tecer algumas frases pode não representar a gratidão que sinto as pessoas quem irei mencionar, mas é uma forma de agradecer por terem feito parte desse período que mudou minha vida das mais distintas formas.

Agradeço, primeiramente, à Lúcia que foi e é muito mais do que uma orientadora. A cada nova leitura e discussão que se dispôs fazer comigo, a cada conselho e a cada bronca, aumentava ainda mais a admiração que sentia por ela. Apesar de ter sido difícil parar de chamá-la de "senhora", com o tempo tornou-se uma ótima companheira de cafés, uma parceira de fugas para almoços no shopping e uma amiga que sempre acreditou em meu trabalho, mesmo quando eu julgava que a situação estava deveras periclitante, e esteve ao meu lado, apoiando-me, em situações que nunca pensei vivenciar.

Agradeço às professoras Silvia Trivelato e Adjane Tourinho que deram dicas valiosas em meu exame de qualificação e contribuíram imensamente para a conclusão de minha pesquisa.

Agradeço à Anna Maria Pessoa de Carvalho, sempre muito enfática em seus apontamentos durantes as reuniões de grupo, mas sempre muito atenciosa e solícita a ajudar no que fosse preciso.

Agradeço ao pessoal do LaPEF por tornar a vida em laboratório mais divertida, por aguentarem meu azedume cotidiano e, também, por contribuírem com o desenvolvimento do meu trabalho. Ana Paula baiana-carioca, obrigado por estar presente com sua amizade e pegar no meu pé, Bia, obrigado pela doçura e carinho, Tiago, obrigado pelas conversas e por me ensinar que vídeo-game não é coisa de preguiçoso, Yadrán, obrigado pelas dicas de congressos e pelo 'rotterone' em espanhol, Leandro, obrigado por compartilhar suas dúvidas e me deixar na dúvida, Nicolli, obrigado por me ajudar a encontrar aquelas referências do século passado e por me ensinar a fazer café, Helena, obrigado por me apoiar nas vezes que quis que a Lúcia não fizesse reuniões em véspera de feriado e por passar por 
tudo isso comigo desde quando éramos do 'grupo das pedagogas' (saudades, Ligia), Nelson, obrigado por sua experiência e pelos dados, sem eles não teria conseguido.

Agradeço ao meu querido Ricardo, meu companheiro de vida que sempre se preocupou em estar ao meu lado, apoiando-me e não deixando que eu desistisse só porque as coisas começaram a ficar dificeis, aguentando pacientemente minha ansiedade e insegurança e tornando minha trajetória mais leve e mais feliz.

Agradeço à minha família, principalmente, a Dona Regina e o Seu Gentil, pais que me incentivaram sem nunca terem conseguido entender o que eu realmente faço, e a Déia, minha irmã que sempre foi minha referência e a pessoa que sempre me espelhei.

Agradeço à minha dupla, Dricia, parceira desde os tempos da graduação e que sempre me incentivou a continuar.

Agradeço à Monaliza, pela companhia nas inúmeras tardes gastas resolvendo listas de exercícios, por compartilhar de angústias e sempre estar por perto.

Agradeço à Babylon, Filipe, Cris, Fran, Rubinha, Felipão e Bárbara, por estarem, mesmo longe, sempre presentes, divertindo-me com conversas descontraídas e inapropriadas e fazendo com que eu não esquecesse que 'eu mereço ser feliz’!

Agradeço, por fim, aos meus amigos da ZN, Rê, minha ídala, Rafinha, Tuka e Gui, que entendiam, às vezes, quando eu deixava de vê-los só pra poder dormir um pouco mais ou finalizar um trabalho qualquer.

Enfim... Obrigado a todos! 


\section{RESUMO}

FERRAZ, A. T. Propósitos epistêmicos para promoção da argumentação em aulas investigativas de Física. 2015. 175p. Dissertação (mestrado) - Instituto de Física e Faculdade de Educação da Universidade de São Paulo, 2015.

O presente trabalho foi elaborado com o intuito de mapear quais ações tomadas por um professor promovem a argumentação dos estudantes. Para isso levamos em conta o contexto do ensino por investigação e a importância dessa abordagem didática para a promoção da Alfabetização Científica. Caracterizamos o que é o ensino por investigação e explicitamos qual é o espaço da argumentação em um ambiente de ensino pautado em seus pressupostos. Com base na revisão da literatura, discutimos especificidades em torno do que vem a ser argumentação em sala de aula e qual a sua importância para a construção de entendimento pelos estudantes sobre conteúdos científicos, bem como seu espaço na implementação de abordagens investigativas. À luz dessas conjecturas, estruturamos um grupo de categorias denominadas propósitos epistêmicos para promoção da argumentação que, em conjunto com os indicadores de alfabetização científica propostos por Sasseron (2008) e com os tipos de perguntas realizadas pelo um professor propostas por Machado (2012), nos permitiu construir um instrumento analítico para estudo de uma situação empírica de sala de aula. Nossa fonte de dados consistiu nos registros oriundos da implementação de uma Sequência de Ensino Investigativa que abordou o tema dualidade onda-partícula da luz. Por meio da análise das transcrições das falas de alunos e professor referentes às duas aulas finais desta sequência de ensino foi possivel encontrar diferentes tipos de argumentos construídos pelos alunos e estabelecer como estes foram favorecidos. Concluímos, entre outras coisas, que o professor exerce papel importante para a promoção e o desenvolvimento de situações argumentativas, uma vez que nossa interpretação dos dados evidenciou aspectos, como, por exemplo, a necessidade da retomada de informações, da problematização de situações de investigação e exploração de distintos pontos de vistas para a construção de argumentos e entendimento pelos alunos sobre o objeto que estava sendo investigado coletivamente.

Palavras-chave: Argumentação; Ensino por Investigação; Alfabetização Científica. 
FERRAZ, A. T. Epistemic purposes to promote argumentation in inquirybased classes. 2015. 175 f. Master's tesis - Instituto de Física e Faculdade de Educação da Universidade de São Paulo, 2015.

This research was performed aiming to map out which teacher's actions can promote argumentation by students. Therefore, we considered the context of inquiry-based teaching and the importance of this didactic approach to promote Scientific Literacy. We characterized the inquiry-based teaching and explained what is the place occupied of argumentation in an educational environment based on their assumptions. Based on the literature review, we discussed what is argumentation and its relevance to building up understandings by students about scientific contents. In light of these conjectures, we have structured a category group called epistemic purposes to promote argumentation that, together with the scientific literacy indicators proposed by Sasseron (2008) and the types of questions asked by a teacher proposed by Machado (2012), allowed us to design an analytical tool to study classroom empirical situation. Our data source consisted of records arising from the implementation of an Inquiry-based Teaching Sequence that addressed the subject wave-particle duality of light. Analyzing the transcripts of the speeches of students and teachers concerning to the final two classes of this teaching sequence was possible to find different types of arguments built by students. We concluded, among other things, the importance of the role of the teacher to promote the development of argumentation situations, since our interpretation of the data indicated aspects, as, for example, the need for resumption information, the questioning of situations and exploration of different points of views to construct arguments and understanding by students about the object that was being investigated collectively.

Key-words: Argumentation, inquiry-based teaching, scientific literacy. 


\section{SUMÁRIO}

1. DELIMITAÇÃO DO CONTEXTO DA PESQUISA .......................... 10

1.1. SOBRE OS OBJETIVOS DO ENSINO DE CIÊNCIAS..............................10

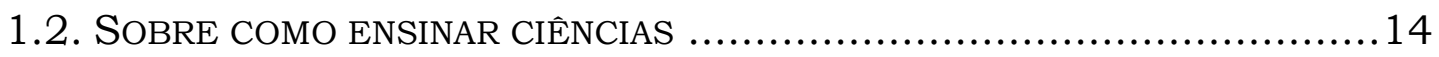

1.3. SobRE AS PERSPECTIVAS E OBJETIVOS DESTA PESQUISA ..................... 17

2. ENSINO POR INVESTIGAÇÃO E ARGUMENTAÇÃO..................... 19

2.1. ENSINAR CIÊNCIAS POR INVESTIGAÇÃO ......................................... 19

2.1.1. Ensino por investigação: Uma abordagem didática ................ 23

2.1.2. Atividades e Sequências de Ensino Investigativas................... 26

2.2. O PAPEL DA ARGUMENTAÇÃO NO ENSINO POR INVESTIGAÇÃO ..................33

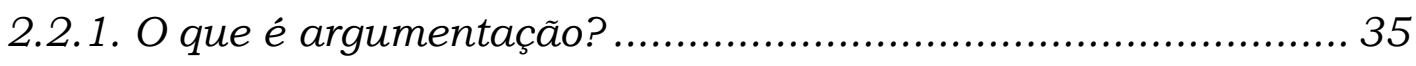

2.2.2. A argumentação no ensino de ciências ................................... 40

2.3. ESPAÇO INTERATIVO DE ARGUMENTAÇÃO COLABORATIVA......................41

2.4. O PAPEL DO PROFESSOR NA PROMOÇÃO DA ARGUMENTAÇÃO ................47

3. INVESTIGANDO O PROCESSO ARGUMENTATIVO .................... 51

3.1. INVESTIGANDO ARGUMENTAÇÃO E ARGUMENTO ..............................51

3.2. DifERENTES USOS DO PADRÃO DE TOULMIN ..................................56

3.3. SuRGiMENTO E DESENVOLVIMENTO DA ARGUMENTAÇÃO ......................61

3.4. FORMAS DE PROMOVER A ARGUMENTAÇÃO …................................66

3.5. PROPÓSITOS EPISTÊMICOS PARA PROMOÇÃO DA ARGUMENTAÇÃO ...........70

\section{METODOLOGIA DE PESQUISA, DADOS E ALGUNS RESULTADOS}

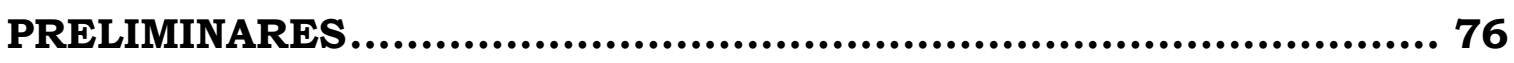

4.1. Metodologia de PESQUisa: PREssupostos teÓRICOs.....................76

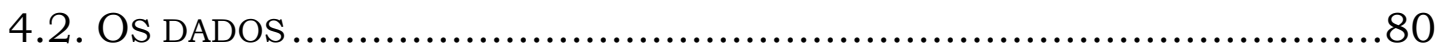

4.2.1. A Sequência de Ensino Investigativa ..................................... 80

4.2.2. Coleta de dados e os participantes da pesquisa .................... 82

4.2.3. Os dados de análise ........................................................... 83 
4.3.ALGUNS RESULTADOS PRELIMINARES.................................. 84

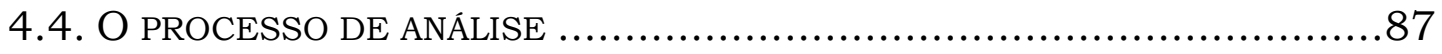

5. ANÁLISE DOS DADOS E DISCUSSÃO DOS RESULTADOS ........... 91

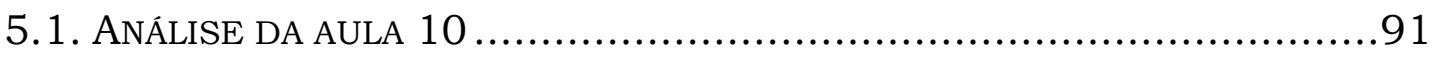

5.1.1. Episódio 1 - Retomando informações ............................. 93

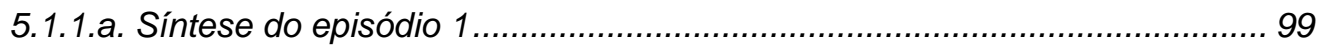

5.1.2. Episódio 2 - Explorando situações .................................. 101

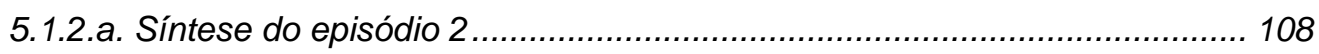

5.1.3. Episódio 3 - Evidenciando incoerências........................... 110

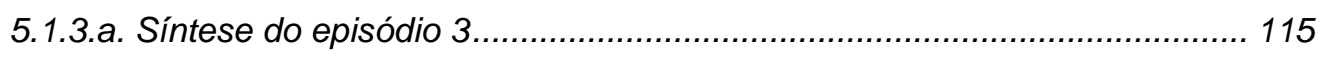

5.1.4. Episódio 4 - As quatro interpretações da quântica .............. 117

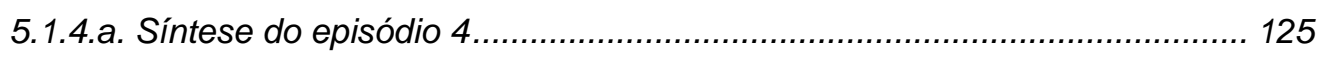

5.1.5. Episódio 5 - Interferência para um único fóton .................. 129

5.1.5.a. Síntese do episódio 5........................................................................ 133

5.1.6. Episódio 6 - Sistematização e encerramento....................... 135

6. ALGUMAS CONCLUSÕES................................................139

7. REFERÊNCIAS BIBLIOGRÁFICAS..................................143

ANEXOS..................................................................149

AnEXo A - SEQUÊnCIA DE Ensino InVESTIGATIVA ADAPTADA ................ 150

ANEXo B - ATIVIDADE DE SISTEMATIZAÇÃO DA AULA $10 \ldots \ldots \ldots \ldots \ldots \ldots \ldots . . . . . . . . .158$

ANEXO C - TRANSCRIÇÃO E CLASSIFICAÇÃO DA AULA ANALISADA ............... 159

(a) Figuras utilizadas pelo professor durante a investigação ......... 159

(b) Transcrição integral das falas ocorridas na aula 10 ............... 160 


\section{DELIMITAÇÃO DO CONTEXTO DA PESQUISA}

Com o intuito de situar este trabalho no contexto das pesquisas na área de educação em ciências, nossa discussão será iniciada com a apresentação de um breve panorama sobre o ensino de ciências na educação básica, destacando aspectos relacionados aos objetivos pretendidos no que diz respeito a formação dos estudantes. Em seguida serão expostos os três pontos centrais a serem explorados nesta pesquisa que serão desenvolvidos nos capitulos subsequentes: ensino por investigação, Alfabetização Científica e argumentação. Finalmente, ao final deste capítulo serão apresentados nossa questão de pesquisa e os objetivos gerais e específicos que almejamos contemplar.

\subsection{SOBRE OS OBJETIVOS DO ENSINO DE CIÊNCIAS}

Ao longo do século XX, a instituição escolar passou por diversas mudanças, moduladas, de maneira geral, com o intuito de promover o avanço político, econômico, cultural e social do país. Dado o foco ao ensino de ciências, adotamos como ponto de partida para a nossa breve reflexão o ano de $1961 \mathrm{em}$ que a Lei 4.024 de Diretrizes e Bases da Educação Nacional (LDB) foi promulgada. Foi a partir desse momento que as ciências começaram a ganhar espaço, ainda que pequeno, na educação básica, apesar de apenas em 1971 com a LDB 5.692, ter se instituído a obrigatoriedade de se ensinar ciências aos oito primeiros anos escolares.

O estabelecimento de novas leis, bem como a proposição de reformas e metas a serem atingidas pela escola, afetam os membros que compõem essa instituição de diferentes maneiras, pois, em essência, são esses documentos que norteiam o trabalho em sala de aula e influenciam diretamente a finalidade que almeja com o ensino. Para citar alguns exemplos na área de ciências, tivemos, entre a década de 50 e 70, momentos históricos bastante marcantes. Durante a 
guerra fria e a corrida espacial entre Estados Unidos e União Soviética, criou-se medidas políticas e um grande investimento financeiro para produzir projetos de ensino que, ao serem implementados na escola básica, permitiriam identificar e incentivar os estudantes a seguirem carreiras científicas ou correlatas. Nessa perspectiva, os objetivos do ensino de ciências estavam totalmente voltados à formação de pessoas que pudessem auxiliar no desenvolvimento científico e tecnológico das nações e se expandiram de tal forma que atingiram, inclusive, as escolas em âmbito nacional. Assim sendo, a função das disciplinas científicas era desenvolver nos estudantes o domínio de saberes da ciência por meio da apropriação de algoritmos de um suposto método científico. A finalidade da escola nesse momento era bastante clara e tinha um cunho essencialmente propedêutico uma vez que se enfatizava a formação técnica dos estudantes em detrimento da formação para exercício crítico da cidadania (KRASILCHIK, 2000).

Com o passar dos anos, várias outras mudanças foram sugeridas e colocadas em execução. No Brasil, foi a partir da promulgação da LDB 9.394, no ano de 1996, que se estabeleceu a obrigatoriedade de a escola dedicar esforços para preparar os estudantes para exercerem tanto práticas sociais como profissionais. Nesse contexto, esperava-se que, ao passar pela escola básica, um individuo fosse capaz de dominar a leitura, escrita e o cálculo, que compreendesse os valores que fundamentam a sociedade, bem como aspectos ligados à questões políticas, econômicas, tecnológicas e ambientais (KRASILCHIK, 2000).

Nos últimos anos, outros documentos foram elaborados de forma a atender as novas demandas da sociedade e promover o avanço da nação. $O$ objetivo de formar trabalhadores não se manteve em primeiro plano como década de 1990. A formação escolar, então, passou a incluir a formação de princípios éticos, políticos e estéticos pelos estudantes (BRASIL, 2013). Em outras palavras, a escola volta-se à formação geral do cidadão. Nesse processo deveriam ser trabalhadas ações que permitissem não só o desenvolvimento cognitivo, mas que enfocassem também aspectos culturais e sociais que fazem parte da realidade dos estudantes.

Em qualquer momento histórico, a mudança do quadro de objetivos da escola tende a afetar não só a forma como os estudantes serão formados, mas também altera as práticas didáticas e pedagógicas que se engendram pela sala de aula. Ou seja, se os objetivos educacionais mudam, a forma de ensinar também é modificada. 
Nesse sentido, muitos esforços têm sido feitos para que o ensino de ciências aborde e explicite aos estudantes mais do que somente conceitos científicos. Grande ênfase tem sido dada para colocar em evidência aspectos ligados ao próprio fazer científico (LEMKE, 1997; JIMÉNEZ-ALEIXANDRE et al., 2000). Em consonância com esta perspectiva, emerge a necessidade de atentar para que sejam abordadas em sala de aula questões relacionadas à construção de entendimento sobre distintos conteúdos, bem como proposição e uso destes conhecimentos em diferentes contextos, sejam, por exemplo, sociais ou históricos, de forma a criar condições para que os estudantes encerrem seu período escolar capazes de atuar criticamente no espaço onde vivem, mesmo se optarem por não seguirem seus estudos em instituições formais de ensino.

Frente aos inúmeros conhecimentos já consolidados e a impossibilidade de abordá-los em sua completude durante curto período escolar, os tópicos e conteúdos que compõem os currículos de ciências inevitavelmente passam por um processo de seleção para cumprir com as metas e objetivos almejados pela educação básica. A escolha de temas e conteúdos a serem abordados não é aleatória e é feita de maneira que, ainda que sejam estruturados e apresentados recortes, possibilite aos estudantes concluírem suas formações sendo capazes de compreender e utilizar saberes, procedimentos e atitudes próprias do corpo de conhecimento da ciência.

Configura-se então um quadro em que o ensino de ciências deve ser planejado e implementado de forma a não reforçar visões equivocadas sobre sua natureza e epistemologia, em outras palavras, busca-se que os estudantes não associem ao conhecimento e trabalho científico a construções puramente indutivas, algoritmicas e aproblemáticas. A ciência, além de ser uma produção coletiva é diretamente influenciada pelo contexto histórico do momento de sua produção, que inclui, entre outros, a tecnologia que se tem disponivel, bem como interesses políticos e econômicos que viabilizam a sua produção e desenvolvimento. Assim, devido a suas particularidades e à grande complexidade dos processos que originaram os conhecimentos científicos, o ensino das ciências $^{1}$ também se torna uma atividade complexa e problemática, principalmente por não haver uma mudança continua das tradições e práticas escolares (BORGES, 2002).

\footnotetext{
1 Apesar de frequentemente utilizarmos termos "ensino de ciências" e "aulas de ciências", é relevante destacar que mesmo com essa referência genérica, também estamos nos referindo às áreas de Biologia, Física e Química.
} 
Desse amplo panorama emergem questões como: Quais conteúdos ensinar nas aulas de ciências?; Como ensinar ciências evidenciando elementos que a compõem, como, por exemplo, suas formas de raciocínio e compreensões sobre a natureza?; e, Como trabalhar em sala de aula, junto aos elementos da epistemologia da ciência e do trabalho científico, aspectos sociais, históricos e culturais que se engendram por esse campo tão vasto?

Em âmbito nacional, para responder a essas questões, além das LDB, contamos com o apoio de outros documentos oficiais como, por exemplo, as Diretrizes Curriculares Nacionais para o Ensino Médio (DCNEM) (BRASIL, 2013) e os Parâmetros Curriculares Nacionais (PCNs e PCNs+) (BRASIL, 1999; 2002) que norteiam o trabalho nas escolas. Esses materiais organizam temas, tópicos e conteúdos a serem abordados em aulas de ciências, bem como habilidades que devem ser priorizadas durante o processo de formação dos estudantes.

É fato que os estudantes da escola básica não precisam aprender em profundidade a infinidade de fenômenos, conceitos, termos e vocabulário que compõe o conhecimento científico. Essa visão é compartilhada por inúmeros trabalhos de pesquisas e também nos documentos acima mencionados que, por sua vez, concentram parte de seus esforços em sugerir que seja dada ênfase ao ensino de temas e conceitos científicos unificadores ao invés da abordagem de grandes listas com tópicos e conteúdos teóricos relacionados a cada campo disciplinar.

Com base nos elementos contidos nos documentos oficiais e nos resultados obtidos pela área de educação em ciências, emerge a necessidade de tornar o ensino de ciências uma prática que permita aos estudantes compreenderem, entre outras coisas, o que é ciência, como ela funciona, quais são seus constructos, como estes são gerados e quais as implicações que podem ocasionar ao meio ambiente e ao contexto econômico, político e social que vivenciam.

Nessa perspectiva, fala-se em Alfabetização Científica (AC), uma vez que, além dos aspectos já mencionados também é almejado que nossos alunos sejam possibilitados a desenvolverem capacidades de organizar seus pensamentos de maneira lógica, além serem aptos a construírem uma consciência mais crítica em relação ao mundo que os cercam (SASSERON, 2008).

O conceito de Alfabetização Científica não é recente e é discutido por diferentes autores, em diferentes contextos, sob a perspectiva de diferentes referenciais e enfoques (por exemplo, LORENZETTI; DELIZOICOV, 2001; 
ROBERTS, 2007; SASSERON, 2008). Devido à grande quantidade de trabalhos e pesquisas sobre o tema, este pode ser considerado um dos objetivos centrais do ensino de ciências, pois ao participarem do processo de alfabetização científica os estudantes serão capazes de compreender as ideias centrais da ciência e aplicarem seus conhecimentos tanto na tomada de decisões sobre problemas pessoais e sociais que possam vivenciar (SASSERON, 2008).

À luz dos objetivos do ensino de ciência e se ancorando na ideia de que o entendimento da natureza da ciência pelos estudantes é um componente crítico e essencial para que se atinjam os objetivos da Alfabetização Científica (LEDERMAN, 2006), emerge uma nova questão: como favorecer a compreensão pelos estudantes de aspectos centrais que originaram o conhecimento científico e sua vasta gama de produtos e subprodutos que permeiam o nosso cotidiano?

\subsection{SOBRE COMO ENSINAR CIÊNCIAS}

Buscar melhorias para o ensino de ciências implica, entre outras coisas, compreender como se dá os processos de ensino e aprendizagem em sala de aula. Ao nos debruçarmos sobre questões ligadas a estes processos deparamos com inúmeras variáveis que se engendram pelo contexto escolar e que, mesmo estando intrinsecamente sobrepostas, necessitam ser selecionadas. É com base na análise desses componentes que se torna possível a obtenção de conclusões mais pertinentes à área e, na medida do possivel, sejam feitas sugestões de mudanças coerentes com os objetivos de ensino almejados por diferentes demandas.

É bem aceito pelas áreas de educação e ensino de ciências que os estudantes terão maiores oportunidades de compreender as nuances que circundam a natureza da ciência e os processos de uma investigação científica que possibilitaram o seu desenvolvimento se passarem por situações em que possam "fazer ciência" (JIMÉNEZ-ALEIXANDRE et al., 2000).

$\mathrm{Na}$ literatura há visões que complementam a ideia do fazer ciência em sala de aula, como, por exemplo, a elaborada por Lederman (2006) após uma análise crítica dos objetivos apresentados em reformas curriculares norte-americanas:

Fazer ciência é certamente um começo, mas os alunos precisam refletir sobre o que é que eles estão fazendo. Eles precisam estar envolvidos em discussões de porque as investigações científicas 
são planejadas de certas maneiras. Os estudantes precisam discutir os pressupostos inerentes a qualquer investigação científica e as implicações que esses pressupostos têm para os resultados obtidos. Além disso, os estudantes precisam discutir o fato de que a ciência é feita por humanos e as implicações que isso tem para o conhecimento que é produzido. (LEDERMAN, 2006, p. 315, tradução nossa)

De fato, assim como destacado por Lederman (2006), acreditamos que os estudantes precisam ir além do fazer ciência em sala de aula. Eles também precisam construir entendimento como o conhecimento científico foi gerado, bem como quais as limitações de seus produtos a depender do contexto em que se inserem.

A ciência é construída, invariavelmente, por meio de processos de investigação e este é o elemento central da epistemologia do conhecimento científico. A investigação refere-se essencialmente à combinação de habilidades específicas, tais como observação, inferência, previsão, dedução, abdução, indução, classificação, questionamento, interpretação e análise de dados, com outros elementos processuais ditos tradicionais, como, por exemplo, levantamento e organização de conhecimentos pré-existentes, raciocínios lógicos e posicionamento crítico.

Diferentes estratégias, metodologias, abordagens e práticas didáticas e pedagógicas podem ser frutíferas do ponto de vista do interesse em promover a Alfabetização Científica dos estudantes, todavia, nos últimos anos ensino por investigação tem ganhado destaque e se tornado uma tendência em pesquisas da área de educação em ciências (ZÔMPERO; LABURÚ, 2011).

Ensinar ciências por meio de investigação tem se mostrado uma forma bastante eficaz de possibilitar os estudantes fazerem ciência e aprimorarem suas compreensões sobre os diferentes aspectos que compõem a natureza do conhecimento científico. É num contexto de investigação que é favorecido que os estudantes observem fenômenos, emitam e testem hipóteses, confrontem inferências e pontos de vistas, avaliem e construam explicações e conclusões, etc. Entretanto, ainda é pertinente nos questionarmos como a implementação de práticas que levam para sala de aula características de uma investigação científica pode proporcionar a Alfabetização Científica dos estudantes.

Introduzir um estudante em um processo de investigação não implica em solicitar que ele reinvente o conhecimento científico, mas sim que ele seja favorecido a construir entendimento sobre como as explicações científicas 
vigentes foram elaboradas e de forma a se posicionem criticamente sobre elas, utilizando-se dessas informações em outros contextos de suas vidas.

Ao propor uma explicação a um determinado fenômeno, um pesquisador precisa, invariavelmente, passar por um processo de investigação, no qual deve justificar suas conclusões, selecionar variáveis relevantes à situação em estudo, relacionar dados com evidências, testar hipóteses de forma a garantir que estas sejam legitimadas, definir em qual contexto suas ideias são válidas confrontando explicações alternativas ou explicitando condições de contorno. Nesse sentido, a criação dos entornos que tornam a explicação de um pesquisador válida, nada mais é que um processo de argumentação, pois é nesse momento que são relacionados dados, justificativas e conclusões, ou seja, estrutura-se um argumento que possibilita a compreensão e entendimento de um determinado fenômeno ou objeto.

Neste ponto, não queremos dizer que a criação de senso crítico necessita apenas de emissões de opiniões com base em levantamento e teste de hipóteses, mas sim que as alegações proferidas sejam sempre justificadas de forma coerente, considerando diferentes fontes de evidências, raciocínios e garantias de maneira semelhante a argumentação científica. Estas ações são favorecidas pelo ensino por investigação que promove a ocorrência de um espaço interativo de situações argumentativas e aprendizagem sobre diferentes objetos, fenômenos e situações, assim como em episódios da própria ciência.

Diversas são as ações que são desempenhas, fomentadas e desenvolvidas pelos estudantes durante o intercurso de uma abordagem investigativa em sala de aula, mas dedicaremos nesta pesquisa maior atenção aos aspectos ligados ao raciocinio científico e posicionamento crítico frente a objetos e situações de investigação.

Posicionar-se criticamente e fazer uso de raciocinios e lógicas semelhantes aos que podemos encontrar em episódios da epistemologia da ciência são características que estão em consonância com os propósitos da AC.

É relevante destacar que uma das razões pela qual o ensino por investigação ganha papel privilegiado no processo de AC dos estudantes é o fato de esta abordagem possibilitar que o trabalhado em sala de aula contemple, além dos conteúdos conceituais da ciência, os conteúdos atitudinais e procedimentais, os quais estão presentes explicitamente em nossos PCNs (BRASIL, 1999; 2002); ou, ainda, permite que se estabeleçam as bases fundamentais da educação, tal qual expresso em documentos oficiais mais recentes, como, por exemplo, as 
DCNs (BRASIL, 2013) que destacam a necessidade de se trabalhar e desenvolver em nossos estudantes princípios éticos, políticos e estéticos relacionados a diferentes corpos de conhecimento.

Sendo assim, o ensino por investigação se mostra um caminho frutífero para se promover a $\mathrm{AC}$, pois possibilita o engajamento dos estudantes em situações nas quais lhes são dadas oportunidades de fazerem ciência, utilizandose de atitudes próprias da cultura científica. É nesse sentido que se torna fundamental compreender as práticas e os processos que circundam essa abordagem didática.

Dado esse panorama o propósito central desta pesquisa é delineado ancorado no fato de que, quando são confrontados com situações que exigem a compreensão e reflexão sobre as alegações que emitiram, os estudantes precisam ser possibilitados a desenvolverem a capacidade de articular evidências e incorporar justificativas às suas conclusões. Nesse sentido explicitamos o anseio de contribuir para construção de melhor entendimento sobre como a argumentação no contexto do ensino por investigação pode ser promovida e fomentada em sala de aula.

\subsection{SOBRE AS PERSPECTIVAS E OBJETIVOS DESTA PESQUISA}

Para o desenvolvimento de nossa pesquisa, nos apoiaremos em pressupostos sociointeracionistas que afirmam que aprender é uma atividade essencialmente coletiva e vislumbramos o ensino por investigação como uma abordagem didática que permite atingir os propósitos já apresentados, pois torna o espaço de sala de aula um ambiente repleto de interações, sejam estas entre alunos, aluno e professor, alunos e materiais didáticos e intelectuais, ou até mesmo dos alunos com o ambiente físico onde estão situados.

Ainda no contexto da sala de aula e explicitando a importância das interações entre os membros que a compõem, ressaltamos ser imprescindível o professor atuar como agente criador de um ambiente propício ao surgimento e desenvolvimento de habilidades próprias do conhecimento científico nos estudantes. É o professor que instrumentaliza os estudantes com ferramentas apropriadas para avanço do raciocínio e compreensão de conteúdos científicos e a construção de argumentos. 
Sendo assim, dada a importância de se pensar em um ensino de ciências que vise à construção de entendimento pelos estudantes de aspectos centrais da ciência, o contexto do ensino por investigação e o papel essencial do professor nesse ambiente para o aprendizagem dos estudantes, colocamos como objetivo dessa pesquisa responder a seguinte questão: Quais ações tomadas pelo professor promovem o surgimento e desenvolvimento da argumentação pelos estudantes no contexto do ensino por investigação?

Finalmente, acreditamos que ao buscarmos responder a questão mencionada, será possível também compreender melhor a relação entre ensino por investigação e argumentação, como o professor favorece e estimula o engajamento dos alunos na prática de investigação, de que forma os alunos relacionam os conhecimentos que possuem com outros que estão em construção em como ocorre o processo de construção de argumentos. 


\section{ENSINO POR INVESTIGAÇÃO E ARGUMENTAÇÃO}

Neste capitulo apresentaremos os referenciais teóricos que nos permitiram estruturar os alicerces para atender nossos objetivos. Iniciaremos detalhando concepções encontradas na literatura da área sobre o que é o ensino por investigação. Com base nesse levantamento, discutiremos as razões que nos levam a compreender o ensino por investigação como uma abordagem didática e explicitaremos os elementos norteadores para seu planejamento e implementação em sala de aula. Em seguida, apresentaremos uma discussão sobre o que vem a ser argumentação na concepção de diferentes pesquisadores para, então, definila conforme nossos objetivos. Finalmente, associando ensino por investigação e argumentação, evidenciaremos como ambos se relacionam e qual é o papel do professor nesse contexto.

\subsection{ENSINAR CIÊNCIAS POR INVESTIGAÇÃo}

Discutimos no capítulo anterior que tanto pesquisas na área de educação em ciências como documentos oficiais que regem o trabalho nas escolas, enfatizam que o ensino de ciências deve possibilitar que os estudantes construam entendimentos sobre distintos fenômenos, conceitos e outros elementos que compõem a epistemologia da ciência e do trabalho científico. Emerge desses objetivos que os estudantes sejam capacitados a articularem relações entre diferentes conteúdos e conhecimentos, o que ocasiona a necessidade de, em sala de aula, promover e trabalhar compreensões sobre a forma como a ciência é construída, bem como questões sobre sua própria natureza (LEDERMAN, 2006; ROBERTS, 2007).

Essas características e objetivos de ensino estão de acordo com o que alguns trabalhos da área chamam de Alfabetização Científica (AC). A definição do que vem a ser AC possui uma vasta gama de valores teóricos e influências 
curriculares, sociais, politicas e econômicas. Sendo assim, com o intuito de minimizar a polissemia acerca do termo, usaremos a definição de Sasseron (2008) que se ancora nas concepções sobre alfabetização proposta por Paulo Freire:

(...) usaremos a 'alfabetização científica' para designar as ideias que temos em mente e que objetivamos ao planejar um ensino que permita aos alunos interagir com uma nova cultura, com uma nova forma de ver o mundo e seus acontecimentos, podendo modifica-los e a si próprios através da prática consciente propiciada por sua interação cercada de saberes de noções e conhecimentos científicos, bem como das habilidades associadas ao fazer científico. (SASSERON, 2008, p. 12)

Colocada a AC como um objetivo do ensino de ciências, para atingi-lo é necessário que haja o planejamento e implementação de abordagens de ensino apropriadas e condizentes com o que se almeja alcançar. Compreendemos que uma das maneiras possiveis para alfabetizar cientificamente os nossos estudantes seja por meio do que a literatura da área de educação em ciências conceitua como ensino por investigação.

A proposta de ensinar ciências por investigação não é recente (ANDRADE, 2001; ZÔMPERO; LABURÚ, 2011). A prática investigativa tem ligação direta com abordagens internacionais publicadas em língua inglesa que utilizam o termo "inquiry" para se referir a, pelo menos, três categorias distintas de atividades: a primeira faz referência a um suposto método científico, ou seja, faz referência a "o que os cientistas fazem", como são os processos de desenvolvimento da ciência; a segunda está relacionada a "como os alunos aprendem" se refere a situações de ensino que usam de metodologias baseadas em investigação que, por sua vez, deve ser realizada pelos estudantes de maneira ativa por meio de ações e reflexões sobre um fenômeno ou problema; e, por fim, pode se referir a uma "abordagem pedagógica" utilizada pelos professores, que planejam ou utilizam de sequências de ensino elaboradas para permitir investigações mais amplas junto aos seus estudantes (MINER et al., 2010).

Em trabalhos nacionais também há variações em torno do entendimento do que vem a ser o ensino por investigação, sendo conceituado de maneiras distintas, como, por exemplo, "aprendizagem por descoberta; aprendizagem por projetos; questionamentos; resolução de problemas, dentre outras" (ZÔMPERO; LABURÚ, 2011, p.68). 
Há, ainda, variações quanto aos seus objetivos. Alguns pesquisadores defendem o ensino por investigação como uma forma de se aprender ciências ao passo que outros defendem que é uma forma de aprender como a ciência foi gerada (GOUW et al., 2013).

As primeiras concepções e proposições de abordagens de ensino baseadas na investigação datam do final do século XIX e começo do século XX. Estas surgiram com o propósito de aproximar os estudantes de práticas próprias da ciência e, apesar das controvérsias que podem ser encontradas na literatura da área, as ideias de John Dewey são as precursoras dessa abordagem (ANDRADE, 2011; ZÔMPERO; LABURÚ, 2011). Para esse filósofo e educador, que também tem seu nome associado a outras metodologias de ensino, como, por exemplo, aprendizagem por projetos e resolução de problemas, a construção do conhecimento seria mais bem sucedida se fosse desempenhado um processo instrumentalista, baseado em um método científico composto por um conjunto de etapas a serem seguidas de forma algoritmica pelos estudantes. Todavia, nessa perspectiva, a educação científica possuía grande ênfase no ensino de fatos e pouco estímulo ao desenvolvimento de raciocínio e as habilidades cognitivas dos estudantes.

A partir da segunda metade do século XX, diversas reformas curriculares passaram a modificar as concepções do ensino por investigação com o intuito de favorecer a formação de novos cientistas, engenheiros e outros profissionais de áreas relacionadas à tecnologia. De maneira análoga, o avanço científico e tecnológico que ocorria de maneira exponencial e a sua influência cada vez maior na organização das sociedades também foi outro elemento que afetou a forma de pensar o ensino de ciências (KRASILCHIK, 2000). Nesse período, o ensino por investigação ganhou espaço expressivo devido ao contexto social, econômico e político da época (ANDRADE, 2011). Foi durante este momento histórico que materiais didáticos para as áreas de Biologia (BSCS - Biology Science Curriculum Study), Física (PSSC - Physics Science Study Committe) e Química (Chem Study Chemical Education Materials Study), foram estruturados e disseminados pelo mundo, incluindo em âmbito nacional, na forma de projetos que tinham como objetivo central que os estudantes desenvolvessem aptidão pelas ciências e outras áreas ligadas à engenharia e tecnologias por meio da imersão em atividades que seguiam um método experimental semelhante a um método científico rígido e algorítmico. 
A principal crítica tecida sobre essas reformas e projetos fica, essencialmente, por conta da possibilidade da construção de uma visão neutra de ciência, desprovida de valores éticos, sociais e históricos que tendia a ser propagada, além de não favorecer a construção de entendimento pelos estudantes de outras características do fazer científico como, por exemplo, os ligados à sua epistemologia.

Em virtude de resultados obtidos por pesquisas feitas por psicólogos, epistemólogos e educadores que se debruçaram sobre questões relacionadas ao desenvolvimento cognitivo das pessoas, e, também, devido às novas demandas da escola básica, houve a necessidade em se almejar novos propósitos ao ensino de ciência. Assim, gradativamente diversas alterações foram incorporadas às práticas de ensinar ciências.

Foi a partir da década de 1990 que as propostas que se baseavam no ensino por investigação começaram a ganhar destaque novamente. Reformas curriculares, principalmente internacionais, passaram a destacar a importância de o ensino de ciências ser coerente com a natureza da investigação científica e da construção da ciência enquanto corpo de conhecimento socialmente legitimado. Neste momento o ensino por investigação deixou de lado o caráter propedêutico que almejava a formação de novos cientistas e passou a ser pensado sob a perspectiva de possibilitar aos estudantes o desenvolvimento de habilidades da cultura científica, bem como a construção de entendimento sobre suas linguagens e tecnologias e a influência que estas exercem na natureza e na sociedade.

Com o aumento expressivo de pesquisas relacionadas à temática do ensino por investigação é possivel inferir a emergência de uma tendência na área de educação em ciências. Essa visão é corroborada por diversos documentos oficiais e estão, inclusive, de acordo com diretrizes de outros países, como, por exemplo, as que estão contidas nos Parâmetros Curriculares Nacionais dos Estados Unidos (NSES - National Science Education Standards) que apresenta de forma explícita uma grande centralidade no ensino por investigação (MUNFORD; LIMA, 2007).

Apesar destes relatos, conforme apresentado por Andrade (2011), apesar da tendência ao ensino por investigação há poucos trabalhos na área que discutem princípios teóricos adotados na hora de conceber o ensino de ciências por investigação. Nessa perspectiva, buscando salientar semelhanças e diferenças entre trabalhos que discutem suas filiações teóricas com relação ao 
ensino por investigação, Zômpero e Laburú (2011) destacam que há algumas convergências no que tange às características dessa abordagem. Com base na análise das diferentes concepções de ensino por investigação analisados por esses autores, o engajamento, a emissão de hipóteses durante a resolução de um problema, a busca por informações e a comunicação dos estudos realizados são essenciais para que os estudantes possam compreender tanto conteúdos teóricos conceituais como aspectos da natureza e da epistemologia do conhecimento científico.

É valido ressaltar que, ainda que a realidade nacional esteja imersa em um contexto diferenciado, as características apresentadas por esses autores estão de acordo com as ideias contidas no documento estadunidense "Investigação e os Parâmetros Curriculares Nacionais de Ciências: Um guia para ensino e aprendizagem" (Inquiry and the Nacional Science Education Standards: A guide for teaching and learning), elaborado para facilitar o acesso dos professores das escolas de nível básico norte-americanas às estratégias promotoras do ensino por investigação. A saber, neste documento é destacado como essencial que os estudantes: engajem-se com perguntas de orientação científica; deem prioridade às evidências ao responder questões; formulem explicações a partir de evidências; avaliem suas explicações à luz de explicações alternativas, em particular as que refletem o conhecimento científico; comuniquem e justifiquem explicações propostas. (NRC, 2000, p.25)

Diante desses apontamentos depreende-se que não há uma única forma possivel para se planejar e implementar abordagens pautadas nos pressupostos do ensino por investigação em aulas de ciências, mas, em contrapartida, há características comuns a todas as concepções apresentadas como o engajamento dos estudantes, emissão e teste de hipóteses e comunicação dos resultados. Torna-se, então, relevante definir algumas das etapas do que é compreendido como ensino por investigação nessa pesquisa.

\subsubsection{ENSINO POR INVESTIGAÇÃO: UMA ABORDAGEM DIDÁTICA}

A investigação é uma prática típica das ciências. Em geral, este processo é desencadeado por uma situação-problema e exige que o pesquisador tenha o domínio e execute diferentes habilidades, intelectuais e manipulativas, necessárias à resolução da questão ou fenômeno sobre o qual almeja construir 
entendimento. Nesse contexto, as ações a serem desempenhadas pelo pesquisador não seguem um roteiro de estratégias pré-definidas, uma vez que a resolução do problema investigado não é conhecida e o caminho para obtê-la é, também, uma incógnita.

A investigação é, então, um processo aberto que, apesar de seguir algumas etapas de controle, possui características determinadas pelo próprio problema de análise e pelo contexto em que este está inserido.

Os métodos de investigação e recursos que são empregados ao intercurso de uma investigação são elementos que fazem parte de uma cultura específica, no caso, a cultura científica. Essa cultura, assim como qualquer outra, possui um conjunto de normas, práticas, crenças, valores e até mesmo dogmas que regem o trabalho científico, a proposição e o desenvolvimento de novos conhecimentos. A ciência possui diversas ramificações que se debruçam sobre fenômenos e objetos de naturezas distintas, isso incorre na existência de várias formas de "fazer ciência", logo a cultura científica não deve ser contemplada como algo rígido e imutável, mas dependente de aspectos de sua natureza e epistemologia.

Apesar de uma investigação científica ser diferente de uma investigação científica escolar em seus propósitos, implementação e desenvolvimento, esse tipo de abordagem em sala de aula tende a possibilitar que os estudantes desenvolvam habilidades próprias da cultura científica sem, entretanto, desconsiderar elementos do ambiente onde estão inseridos, no caso, a sala de aula e o contexto cotidiano do qual fazem parte.

Restringindo-nos ao ambiente escolar, devemos ter claro que este espaço também é regido por uma série de normas, práticas, regras e valores que definem sua própria cultura: a cultura escolar. Assim, ensinar ciências por investigação deve estar em consonância com as expectativas presentes nos documentos e diretrizes oficiais que guiam o trabalho do professor em sala de aula e, também, com as expectativas e anseios individuais de nossos alunos, que devem ser capacitados a opinarem critica e ativamente sobre temas que envolvem ciência e outros assuntos relacionados às demais áreas de conhecimento que permeiam seus cotidianos.

O ensino por investigação, então, deve cuidar para que a abordagem de conteúdos científicos em sala de aula permita que os estudantes construam uma visão apropriada sobre ciência e seus produtos. Ou seja, deve-se atentar para não tornar os conceitos colocados em discussão como construções não passíveis 
de questionamento, aproblemáticos e formulados de modo algorítmico por pessoas privilegiadas de uma pequena elite intelectual.

Emerge desses apontamentos que a construção de sentidos e significados pelos estudantes sobre conceitos científicos é algo essencial tanto para a alfabetização científica como a formação geral enquanto cidadãos críticos e atuantes no espaço onde estão imersos. Além disso, é também imprescindivel que se dê o mesmo valor aos procedimentos e atitudes vinculados à epistemologia da ciência e ao trabalho científico.

Ensinar ciências não se resume apenas a ensinar conteúdos conceituais, do mesmo modo, não se deve enfatizar somente o ensino de procedimentos ou de atitudes da cultura científica. Sob essa perspectiva, o ensino por investigação permite um trabalho integrado com diferentes práticas metodológicas e didáticas, estas que variam de acordo com o perfil do professor e recursos disponíveis para o desenvolvimento de uma aula, por isso o compreendemos como uma abordagem didática (SOLINO et al., 2015). Nossa visão de ensino por investigação se justifica pelo fato de ser uma abordagem que não se restringe a uma única estratégia metodológica de ensino, por não se pautar em um único tipo de atividade e, por ser diretamente dependente do surgimento e da promoção de interações, incorpora especificidades dos professores, dos alunos e do contexto social e cultural que estes fazem parte.

Dessa forma, sua implementação em sala de aula deve ocorrer por meio de ações, atividades, estratégias e metodologias diferenciadas de forma a configurar um ambiente em que professor e alunos possam interagir e colaborar entre si para que o entendimento sobre diferentes temas pelos estudantes seja estruturado, ampliado e aprofundado. Ou seja, o ensino por investigação será de fato investigativo se o professor prover condições para que ele ocorra.

Como mencionado na seção anterior, seja pela diversidade de definições ou pela necessidade de se incorporar diferentes estratégias, é esperado que haja variações no planejamento e implementação de uma abordagem didática pautada nos pressupostos do ensino por investigação. Todavia, alguns pontos são recorrentes e despontam como centrais nesse trabalho, como, por exemplo, a necessidade de que os alunos sejam possibilitados a interagir entre si e a se engajarem e participarem ativamente do processo investigativo, compartilhando ideias e colaborando coletivamente para a construção de entendimento sobre fenômenos e outros conteúdos curriculares explorados. 
O professor, por sua vez, como autoridade epistêmica e social (BERLAND; HAMMER, 2012) deve cuidar para que a participação ativa de seus alunos seja instaurada. É o professor que propõe um problema para investigação e o complexifica com base nos entendimentos apresentados pelos seus alunos, orientando-os de forma que sejam possibilitados a aproximarem suas compreensões e explicações aos conceitos científicos socialmente aceitos naquele momento e que constituem os objetivos da aula. É também o professor que promove a discussão e o debate de hipóteses, solicitando que as conclusões proferidas sejam ancoradas em outros conhecimentos previamente estabelecidos.

Além dos aspectos já mencionados, o professor também deve ter atenção para que o trabalho a ser desempenhado pelos alunos em sala de aula garanta a utilização de práticas, regras, procedimentos, normas e outros elementos tanto da cultura científica como da cultura escolar. A esta abordagem híbrida que valoriza tanto aspectos da ciência como do ambiente escolar, denominamos cultura científica escolar (FERRAZ et al., 2014); e a mesma precisa ser pensada desde o momento do planejamento de uma abordagem investigativa para não incorrer em um ensino pautado na transmissão de conhecimento ou em situações semelhantes a um suposto método científico.

Diante dessas conjecturas, caracterizar o ensino por investigação como uma abordagem didática está em consonância com os propósitos almejados à formação e à alfabetização científica, pois é nesse contexto que os elementos da cultura científica mesclam-se com elementos da cultura escolar de forma que os tópicos tratados em sala de aula favoreçam não só a aprendizagem de conteúdos científicos pelos alunos, mas também o desenvolvimento de uma visão integrada de aspectos sociais e históricos da ciência ou do contexto cotidiano que vivenciam.

\subsubsection{ATIVIDADES E SEQUÊnCIAS DE Ensino InVESTIGATIVAS}

Frequentemente deparamos com o termo atividades investigativas, mas isso não nos permite construir uma visão apropriada sobre o que é ensino por investigação. Reduzir o ensino por investigação às atividades investigativas que podem ser utilizadas ao longo da implementação de um planejamento pode até ser um começo, mas tende a não ser significativo quando se almeja atender às expectativas do ensino de ciências. Além disso, a abreviação dos pressupostos do 
ensino por investigação às atividades investigativas reforça visões equivocadas sobre essa abordagem didática, como, por exemplo, que todos os conteúdos da ciência podem ser trabalhados por meio de atividades práticas que são iniciadas por um problema aberto (MUNFORD; LIMA, 2007).

Com essa discussão queremos ressaltar que não há uma estratégia privilegiada para que o ensino por investigação ocorra em sala de aula. Investigar um objeto, fenômeno ou um conceito pode ser feita de inúmeras maneiras, seja por meio de manipulação experimental ou por leituras de textos e análise de distintas fontes de informações, mas é imprescindivel que o professor permita que seus alunos atuem ativamente deste processo e confronte as ideias que são trazidas à discussão.

Diferentes definições sobre o que é o ensino por investigação podem ser encontradas em documentos oficiais e na literatura da área de educação em ciências, sendo apresentas e analisadas à luz de diferentes enfoques (por exemplo, FLICK; LERDERMAN, 2006; MUNFORD; LIMA, 2007; ZÔMPERO; LABURÚ, 2011). Conceber uma abordagem didática com base no ensino por investigação pode incorrer em erros, como, por exemplo, de que as variáveis e características destas não sejam articuláveis entre si. Portanto, antes de apresentarmos nossa concepção sobre o que como pode ser o ensino por investigação, ressaltamos que essa abordagem didática possui elementos que podem ser mais ou menos evidentes a depender do grau de ensino e da complexidade do conteúdo científico que se almeja abordar junto aos estudantes. Nesse sentido, adaptações podem ser necessárias conforme ocorre o planejamento de atividades de natureza investigativa.

A concepção de ensino por investigação adotada nesse trabalho tem como referencial central os trabalhos de Carvalho (2011a; 2013) que, usando dos resultados obtidos pelas pesquisas de Piaget, Vigotski e Bachelard, deixa evidente alguns aspectos que devem ser considerados ao se planejar atividades investigativas e sequências de ensino investigativas. Em outras palavras, para estruturar o que concebe como ensino por investigação, a autora adota pressupostos construtivistas e sociointeracionistas que estão bastantes presentes em nossas salas de aula, além de destacar aspectos da epistemologia da ciência que também precisam ser considerados.

Os trabalhos de Piaget são utilizados como ferramenta para compreender como um indivíduo constrói entendimento sobre o conhecimento científico. É com base nas ideias desse autor que emergem características de nivel individual, 
como, por exemplo, a importância do problema, a necessidade da passagem da ação manipulativa para a ação intelectual e a importância do erro na construção de entendimentos pelos estudantes. Ainda que não discutidos pela autora, é importante destacar que compreendemos a questão da manipulação algo mais amplo que o manuseio direto de um objeto físico, ou seja, manipular está ligado tanto ao manejo tanto de elementos concretos e empíricos como o de elementos abstratos e teóricos.

De maneira análoga, os trabalhos de Vigostki são utilizados para compreender como o estudante constrói o conhecimento da escola, ou seja, em nivel social. Evidencia-se com isso a importância da interação social entre os estudantes na sala de aula, da mediação, que se refere especificamente ao papel do professor, e da compreensão dos conceitos espontâneos dos estudantes e a construção de conceitos científicos durante o processo de construção de conhecimento ${ }^{2}$.

Por fim, com relação aos trabalhos de Bachelard, a autora ressalta elementos de nivel epistemológico, ou seja, relacionados à epistemologia do conhecimento científico. Dentre os aspectos destacados pela autora a serem considerados em uma abordagem investigativa estão presentes a importância da emissão e teste de hipóteses pelos alunos, a necessidade de se atentar às etapas e raciocínios de uma experimentação científica e, principalmente, questões ligadas à apropriação da linguagem da ciência.

Em Carvalho (2011a), a autora mostra que ensinar ciências por investigação implica, necessariamente, que haja o planejamento de atividades investigativas, justificando que:

ao ensinarmos ciências por investigação estamos proporcionando aos alunos oportunidades para olharem os problemas do mundo elaborando estratégias e planos de ação. Desta forma o ensino de ciências se propõe a preparar o aluno desenvolvendo, na sala de aula, habilidades que lhes permitem atuar consciente e racionalmente fora do contexto escolar. (p. 253)

\footnotetext{
2 É importante ressaltar que as ideias de Piaget e Vigostki não se esgotam nas questões ligadas, respectivamente, ao desenvolvimento cognitivo por meio de práticas manipulativas ou interações sociais. Conforme já mencionado, a estrutura de uma abordagem didática investigativa é dependente de diversos fatores, tais como o perfil do professor que a planeja e a implementa, o nível de ensino com o qual se trabalhará e o conteúdo a ser abordado. Todavia, a discussão sobre esse tópico não será aprofundada neste trabalho devido nossas intenções de pesquisa.
} 
Nesse mesmo trabalho, mas principalmente em sua publicação mais recente, Carvalho (2013), com o intuito de favorecer a compreensão e implementação dessa abordagem em sala de aula, estrutura a ideia de Sequência de Ensino Investigativa (SEI), que, nas palavras da própria autora, são:

(...) sequências de atividades (aulas) abrangendo um tópico do programa escolar em que cada atividade é planejada do ponto de vista do material e das interações didáticas, visando proporcionar aos alunos: condições de trazer seus conhecimentos prévios para iniciar novos, terem ideias próprias e poder discuti-las com seus colegas e com o professor passando do conhecimento espontâneo ao científico e adquirindo condições de entenderem conhecimentos já estruturados por gerações anteriores. (p. 9)

Em outras palavras, é proposto que, por meio da elaboração e implementação de SEIs se configura um ambiente investigativo de forma que é possivel ensinar, conduzir e mediar os estudantes o processo do trabalho científico que, ainda que possam ser apresentados de maneira simplificada, possibilitam que ocorram gradativamente a ampliação da cultura e linguagem científicas, ou seja, possibilita que os estudantes sejam alfabetizados cientificamente.

Uma SEI, do mesmo modo que as atividades investigativas, é estruturada por Carvalho (2013) como uma sequência composta de cinco etapas básicas: proposição do problema; resolução do problema; sistematização de conteúdos, contextualização de conceitos e informações e, por sim, avaliação (ver figura 2.1). Destacamos nesse ponto que estas etapas não podem ser tratadas como estanques e, conforme mencionamos anteriormente, cada uma delas podem ser mais ou menos enfatizadas a depender do contexto ou do conteúdo científico abordado. 


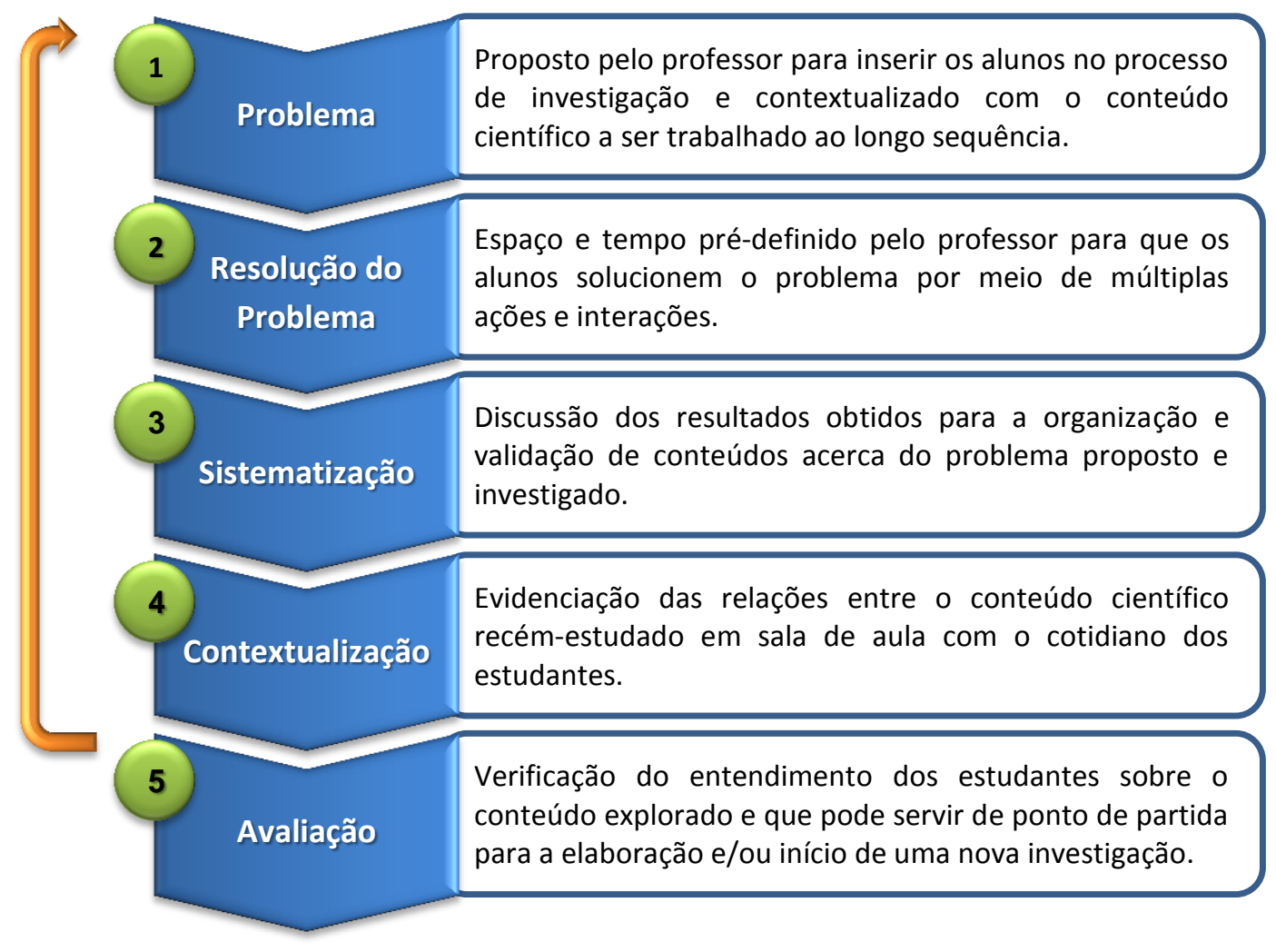

Figura 2.1 - Etapas de uma Sequência de Ensino Investigativa (SEI), conforme proposto por Carvalho (2013).

De acordo com a proposta de Carvalho (2013) que adotamos em nossa pesquisa, uma SEI se inicia sempre com a proposição de um problema. $\mathrm{O}$ problema corresponde ao cerne da investigação e poderá ser solucionado pelos estudantes por meio de atividades de diferentes naturezas, por exemplo, não experimentais, como leituras de textos, experimentais, as quais os estudantes podem manipular equipamentos e instrumentos em busca de dados e resultados, ou demonstrativas, nas quais o aparato experimental é manuseado pelo professor.

A proposição do problema é uma das etapas mais importantes em um SEI. É nesse momento que é possibilitado aos estudantes compreenderem o que deve ser investigado. Além disso, é o entendimento adequado do problema que vai direcionar o trabalho a ser desenvolvido e fazer com que os alunos sintam a necessidade de se apropriar de saberes que ainda não possuem. Sendo assim, é importante ter em mente que é também necessário garantir que os alunos tenham condições para solucioná-lo por meio da emissão e teste de hipóteses, 
com base no trabalho com os materiais e recursos disponíveis, sejam estes concretos ou abstratos.

Compreendido o problema, sua resolução é a etapa seguinte. A resolução do problema é uma etapa que pode ser realizada em pequenos grupos ou coletivamente a depender do planejamento e das diretrizes da atividade. $\mathrm{O}$ professor, nesta etapa, deve estar atento para mediar o fluxo de interações, promovendo-as para que seus alunos explicitem seus entendimentos sobre o que estão investigando e discutam a relação entre as variáveis ligadas ao problema, condições de contorno e a validade das explicações que estão construindo.

Após a resolução do problema, é importante que seja feita uma atividade de sistematização dos entendimentos que foi recém-construído pelos alunos. Sistematizar o conhecimento é uma estratégia fundamental para que, ao final do processo de investigação, todos os alunos tenham mais uma oportunidade de formalizar os entendimentos que construíram acerca do objeto que foi investigado. É valido ressaltar nesse ponto que, apesar da indução de que a sistematização consiste em uma etapa de finalização, ela pode acontecer simultaneamente durante as interações que emergem durante resolução do problema, mas de forma parcial uma vez que o entendimento sobre o objeto de investigação ainda está em construção pelos alunos.

Posteriormente, é relevante que sejam tecidas relações entre os conteúdos que foram abordados com situações contextualizadas com o cotidiano dos alunos. Em outras palavras, a contextualização é a etapa na qual devem ser evidenciadas situações diversas as quais o conteúdo estudado se aplica. A aproximação com o cotidiano favorece não só que os estudantes visualizem a importância do que aprenderam, mas também a compreensão de aspectos sociais relacionados ao conhecimento científico.

Apesar de Carvalho (2013), evidenciar que a contextualização do conteúdo abordado deve fazer relação com o cotidiano dos estudantes, na maioria das vezes é imprescindivel que sejam feitas outras contextualizações. Ricardo (2010) destaca a existência de três formas de contextualização distintas: contextualização sócio-histórica, contextualização epistemológica e contextualização didática. Uma vez que essa etapa da SEI depende significativamente do conteúdo científico que está sendo investigado, nos casos em que se está trabalhando com conceitos de grande complexidade e que exigem um alto grau de abstração, é fundamental que o professor busque fazer contextualizações de naturezas distintas da contextualização com o cotidiano dos 
alunos, ou seja, deve ter o cuidado em relacionar conteúdo explorado não só com situações do dia-a-dia dos alunos, mas também, por exemplo, com os processos históricos, sociais e éticos que se relacionam com os produtos da ciência.

Por fim, assim como em qualquer outra abordagem didática, é necessário que ocorra uma atividade de avaliação. Por se tratar de uma estratégia de ensino inovadora, Carvalho (2013) deixa claro alguns aspectos dessa última etapa quando enfatiza o fato de que "as inovações didáticas devem estar ligadas a inovações na avaliação, pois uma nova postura metodológica em sala de aula torna-se inconsistente aliada a uma postura tradicional de avaliação" (p.10).

No sentido atribuído pela autora a esta etapa, não se deve avaliar o entendimento dos estudantes construído por meio de intervenções investigativas utilizando-se de avaliações tradicionais. É necessário que sejam implementadas avaliações que possibilitem aos estudantes aplicarem suas ideias a diferentes contextos, bem como articularem dados e evidências de forma a justificarem suas alegações. Sendo assim, mesmo que a autora não tenha deixado evidente em seu trabalho, destacamos que a avaliação não deve ser pontual, mas sim continua, pois é essa etapa que se entrecruza com as demais e que possibilita ao professor validar os saberes que foram construídos por seus alunos ao longo do processo investigativo.

As etapas estruturadas por Carvalho (2013) podem se repetir várias vezes a depender do conteúdo curricular que se almeja abordar. Temas mais complexos tendem a exigir que dentro desse ciclo simplificado que caracteriza uma SEI, apresentado detalhadamente acima e na figura 2.1, ciclos semelhantes sejam programados e implementados para que assim seja possivel a proposição de problemas cada vez mais complexos que exigem a elaboração de soluções mais sofisticadas pelos alunos e, por consequência, uma melhor compreensão dos conceitos pelos estudantes ao final do processo.

Com o intuito de reforçar a justificativa da escolha dos trabalhos de Carvalho, resgatamos os apontamentos de Munford e Lima (2007) que destacam serem recorrentes três concepções equivocadas acerca do que é ensinar ciências por investigação. A primeira se refere ao fato de que a investigação deve sempre partir de uma atividade prática. Outro equívoco destacado por essas autoras está relacionado ao fato de que o problema a ser investigado deva ser sempre um problema aberto e, por fim, é frequente encontrar compreensões que defendem que todos os conteúdos científicos podem ser abordados por meio de intervenções investigativas. 
À luz dessas indicações ressaltamos que a proposta das SEIs de Carvalho (2013) evidencia claramente que para se ensinar ciência por investigação não é necessário que exista um problema aberto. Do mesmo modo, as soluções dos problemas de investigação não requerem sempre a realização de atividades práticas pelos alunos, pois tanto a manipulação de um experimento como a leitura de um texto pode incorrer em uma investigação a depender da forma como o professor propõe o problema e conduz e direciona o fluxo de interações ocorrentes em sala de aula.

Finalmente, devido às diversas etapas que a compõem uma SEI, a mesma não é formada somente por atividades investigativas, pois nela estão contidas, por exemplo, atividades de contextualização e de sistematização que apesar de requererem a participação dos estudantes, o professor é o agente central no processo de exposição e sintetização dos conteúdos sobre os quais construíram entendimento.

\subsection{O PAPEL DA ARGUMENTAÇÃO NO ENSINO POR INVESTIGAÇÃO}

Dentre as inúmeras práticas da ciência, a argumentação se destaca por ser um elemento central e, por isso, também precisa ser valorizada e fomentada quando se almeja à AC durante a implementação de atividades e sequências de ensino investigativas.

A relação entre argumentação e ensino por investigação pode ser vislumbrada em diferentes pesquisas na área de educação em ciências. Por exemplo, Sá et al. (2011), no contexto de um curso de formação continuada de professores de educação básica, buscaram construir sentido para o termo ensino por investigação com base nas ideias de Bakhtin e na análise de entrevistas com professores cursistas e tutores. A leitura dos dados que tinham disponiveis revelou a esses autores que "construir um problema; aplicar e avaliar teorias científicas; propiciar a obtenção e a avaliação de evidências; valorizar o debate e argumentação; permitir múltiplas interpretações" (p. 97, grifo nosso) são características que devem estar presentes em atividades de natureza investigativa.

De forma mais direta, Zômpero e Laburú (2011) destacam que:

O ensino por investigação, que leva os alunos a desenvolverem atividades investigativas, não tem mais, como na década de 1960, 
o objetivo de formar cientistas. Atualmente, a investigação é utilizada no ensino com outras finalidades, como o desenvolvimento de habilidades cognitivas nos alunos, a realização de procedimentos como elaboração de hipóteses, anotação e análise de dados e o desenvolvimento da capacidade de argumentação. (p.73, grifo nosso)

Há ainda autores que relacionam explicitamente a argumentação com o ensino por investigação devido à emergência de múltiplas interações que surgem durante o processo investigativo, por exemplo, Carvalho (2013) ressalta que durante a realização de uma investigação, quando o professor solicita aos seus alunos que respondam as questões como? e por quê? o problema proposto e investigado foi solucionado, é favorecido que justificativas às explicações sejam construídas com maior embasamento e a articulação entre evidências e conclusões decorram por meio de um processo que se assemelha à argumentação científica.

As perspectivas apresentadas corroboram com a nossa visão de que os estudantes, quando inseridos em um ambiente que contemple características do ensino por investigação, são estimulados a aprenderem e a desenvolverem determinados procedimentos próprios da cultura científica, como, por exemplo, observar, anotar, manipular, questionar, buscar respostas a seus questionamentos e argumentar. Nesse sentido, o ensino de ciências por meio da investigação, além do compromisso com a alfabetização científica dos estudantes, também favorece a criação de um ambiente privilegiado para a apropriação de saberes e habilidades que ainda não possuem. Do mesmo modo, também é favorecida a construção de entendimento de diferentes conteúdos da ciência, bem como o aprendizado de práticas epistêmicas deste corpo de conhecimento, como, por exemplo, a argumentação, pois é durante o processo de investigação de um fenômeno que os estudantes são requisitados a articularem evidências e conclusões, emitirem e testarem hipóteses, construírem explicações e, consequentemente, seus próprios entendimentos de maneira ativa.

Essa postura indagadora e participativa dos estudantes no aprendizado é o cerne dos pressupostos da Alfabetização Científica e o ensino por investigação deve cuidar para promover um ambiente que permita aos estudantes atuarem dessa maneira, ocasionando situações em que haja a necessidade de os alunos utilizarem de práticas da ciência. A argumentação, por sua vez, desponta-se como essencial nesse processo e, diante de nossos objetivos de pesquisa, deve ser explorado com atenção à luz de referenciais teóricos apropriados. 


\subsubsection{O QUE É ARGUMENTAÇÃO?}

O interesse crescente de pesquisadores sobre temáticas que envolvem a argumentação vem se tornando evidente há tempos e, dentre as pesquisas publicadas, destacam-se trabalhos de diferentes áreas de conhecimento, como, por exemplo, do campo da Filosofia, Psicologia e Educação.

Conceber e definir um conceito são sempre atividades complexas, pois é imprescindivel ter atenção aos valores subjetivos que podem estar incorporados a ele, além de ser necessário ter consciência de condições de exceção que podem invalidar seu entendimento. Tratando-se de algo tão amplo como a argumentação, é fundamental que sejam feitas mais do que meras descrições. É preciso definir características que compõem sua essência e, principalmente, estabelecer os contextos e situações aos quais estas são válidas.

Assim como no caso do ensino por investigação, seja por ser interesse comum de diferentes áreas ou por ser aplicável a diferentes contextos, responder o que é argumentação não implica na obtenção de uma única resposta, podendo haver divergências entre as concepções que são atribuídas a seu significado mesmo dentro de uma mesma linha de pesquisa (LEITÃO, 2007).

Conceitos incorporam, entre outras coisas, a filiação teórica dos pesquisadores que os propõem e por isso precisam ter suas definições explicitadas com cuidado para que não sejam interpretados de maneira equivocada ou incompleta. Além disso, relacionar construções e entendimentos divergentes sobre o significado de um conceito pode delinear fraqueza a estudos de uma determinada área, dado que um campo de pesquisa carece de clareza sobre os conceitos que procura explorar e utilizar como base de referência (OSBORNE; PATTERSON, 2011). Nessa perspectiva, dedicar esforços para estabelecer um melhor entendimento sobre o que vem a ser argumentação, bem como o seu papel em situações de aprendizagem, tende a beneficiar pesquisadores e estudiosos já que permite que estes adquiram maior compreensão acerca de suas acepções teóricas e, a partir disso, planejem e implementem novas abordagens de pesquisa e práticas pedagógicas.

Diante desse quadro, Bricker e Bell (2008) descreveram as concepções teóricas sobre argumentação de diferentes campos de conhecimento e suas implicações para o ensino de ciências. Nesse trabalho os autores relatam que, para o campo da Lógica Formal, argumentação é o meio pelo qual é gerado um produto - um argumento - concebido com base em considerações suscitadas para 
apoiar conclusões, que podem ser validadas dedutivamente. Em outras palavras, no contexto da lógica o argumento é gerado a partir de premissas maiores e menores que apoiam uma dada conclusão, o que incorpora um caráter silogístico agregado a ele.

Outro campo que tem destaque no trabalho desses autores está relacionado às pesquisas voltadas diretamente a teorias argumentativas, que se preocupam com a produção, análise e avaliação da argumentação. Nesse campo os autores se ancoram nas ideias de van Eemeren e Grootendorst (2004 apud BRICKER; BELL, 2008) e destacam que argumentação é uma atividade essencialmente verbal, pois exige o uso da linguagem oral e/ou escrita para ser produzida; social, pois envolve duas ou mais pessoas durante o seu desenvolvimento; e racional, pois almeja convencer criticamente um par à aceitabilidade de um determinado ponto de vista, apresentando um conjunto de proposições que justificam ou refutam a alegação expressa como ponto de vista.

Leitão (2007), em seu trabalho voltado ao campo da psicologia, destaca que o ponto de partida para estudos recentes relacionados à argumentação tem suas concepções formuladas com base em teorias do campo da filosofia contemporânea. No contexto dessas teorias, argumentação é definida como uma atividade essencialmente discursiva, que ocorre por meio da justificação de uma asserção que, por sua vez, pode ter maior ou menor aceitabilidade a depender da consideração proposição e/ou refutação de alegações alternativas.

No campo das pesquisas na área de educação em ciências, essa filiação filosófica a qual Leitão (2007) se refere pode ser observada em inúmeros trabalhos que adotam a obra de Toulmin (1958/2006³) como referência metodológica para avaliar e/ou validar os produtos que foram construídos ao longo de um processo de argumentativo em sala de aula (por exemplo, JIMÉNEZALEIXANDRE et al., 2000; ERDURAN et al., 2004; SIMON et al., 2006).

Ainda no âmbito das pesquisas em ensino de ciências, Jiménez-Aleixandre e Erduran (2008), com base em uma revisão de diferentes trabalhos que tratam sobre argumentação, defendem que o termo pode ser interpretado tanto como uma forma de justificar um conhecimento como uma forma de persuadir uma audiência. Em um trabalho mais recente, Jiménez-Aleixandre (2010) define argumentação como um processo de avaliação de enunciados de conhecimento que toma por base os dados e provas que estão disponiveis naquele momento.

3 A obra de Toulmin foi originalmente publicada em 1958, mas nesta pesquisa foi utilizada a edição traduzida publicada em 2006. 
Nesse contexto, enunciados de conhecimento são caracterizados como, por exemplo, hipóteses, conclusões ou teorias científicas.

Kerlin et al. (2010) defendem que para dar validade a uma afirmação é preciso que seja feita a comunicação das compreensões sobre o que está sendo discutido em sala de aula e que se incorporem justificativas que deem coerência às relações que estão sendo consideradas por meio da argumentação. Nesse sentido, a argumentação refere-se às maneiras utilizadas por um indivíduo para persuadir uma determinada audiência da validade de uma afirmação.

Ainda que a questão da persuasão seja latente na argumentação, ela não deve ser interpretada com um sentido opositivo e agressivo em que dois interlocutores argumentam buscando defender um ponto de vista em detrimento de outro. Para melhor compreensão desse aspecto vinculado ao processo argumentativo, basta pensarmos em uma situação na qual dois pesquisadores, ou grupos de pesquisa, estejam realizando uma investigação para solucionar uma mesma questão sobre qual buscam construir explicações que sejam satisfatórias. Nesse caso, é possivel que ocorram discordâncias em diversos aspectos que necessitam uma ação persuasiva entre eles, mas ao se disporem a aceitar determinadas contribuições uns dos outros de forma colaborativa, há a ocorrência de negociação de significados entre pares. Esta colaboração é propiciada por diferentes interações e é o que possibilita, ao final do processo de argumentação, a construção de um conhecimento mais robusto e coerente sobre o fenômeno ou objeto de investigado.

Algumas propostas em que se pede um posicionamento dos estudantes, sobretudo em questões sociocientíficas, o caráter de persuasão associado à argumentação torna-se muito mais evidente (por exemplo, ERDURAN et al., 2004). É nesse contexto que o estudante é convidado a se posicionar sobre um determinado tema ou questão defendendo seu ponto de vista e refutando posicionamentos concorrentes, mesmo que estes também sejam válidos e coerentes. Todavia, no âmbito das atividades investigativas, a persuasão em seu sentido estrito ocorre como a construção e justificação de uma conclusão, uma vez que os estudantes estão imersos em um ambiente de aprendizagem e trabalhando coletivamente sobre um mesmo objeto e com o intuito de construir uma mesma explicação. É nesse contexto, também, que eles estão construindo relações, estabelecendo garantias e desenvolvendo seu próprio entendimento com base nas observações e aportes teóricos que têm disponíveis ou estão acessando 
por meio das interações entre seus pares, fomentados, especialmente, pelas ações do professor.

Conforme destacam Jiménez-Aleixandre e Erduran (2008), há diferentes dimensões de argumentação. Seus constructos são gerados com diferentes propósitos, pois o ato de argumentar implica em uma prática mais sofisticada do que apenas coordenar alegações e evidências de maneira causal. Por ser um processo interativo e dependente da dialogicidade entre pares, o que implica no compartilhamento de conceitos complexos, na organização lógica de diferentes explicações, na defesa de um ponto de vista e, eventualmente, na persuasão de uma audiência. Em outras palavras, pode-se inferir que as diferentes dimensões relacionadas à argumentação ocasionam o fato de que argumentar é uma ação discursiva que possui propósitos distintos.

Sistematizar um conhecimento ou uma hipótese, defender um ponto de vista e persuadir uma audiência são elementos distintos que estão incorporados à argumentação, mas frequentemente aparecem emaranhados a depender do contexto e dos objetivos que são levados em conta.

No âmbito da ciência, por exemplo, a construção de um novo modelo ou teoria feito por um pesquisador perpassa por todos esses momentos. Para defender uma ideia é necessário que seja feita coerentemente a justificação das conclusões com base em dados, evidências e teorias vigentes, de forma a defender uma explicação e persuadir a comunidade científica e o público que sua hipótese e conclusões são coerentes.

Como destacado por Schwarz (2009):

Estabelecer uma alegação de conhecimento em ciência envolve, em um primeiro momento, o processo de estabelecimento de dados, por meio da realização e verificação de observações e experiências. Em seguida, deduções são feitas com base na teoria que permite fazer conjecturas através de raciocínio e cálculos. À medida que os dados concordam ou discordam com a previsão, então, precisam ser examinados. Ao invés de uma única teoria ou conjectura a ser marcada, muitas vezes há o caso de duas (ou mais) teorias concorrentes. Então, a atividade principal dos cientistas é avaliar qual das possibilidades se relaciona ou não com as evidências disponiveis e, portanto, qual apresenta a explicação mais convincente para fenômenos particulares do mundo. (SCHWARZ, 2009, p.112, tradução e grifos nossos)

No sentido construído por esse autor, um pesquisador, ao propor uma nova teoria, modelo ou explicação, ou seja, a solução de um problema que está 
sob investigação, precisa construir seu próprio entendimento sobre o objeto investigado, selecionando dados, variáveis e informações relevantes ao processo, formulando hipóteses, obtendo conclusões e incorporando justificativas à luz de teorias e outros saberes da ciência; avaliar as razões que permitem estabelecer as explicações que almeja propor; e expor suas ideias de forma formalizada e coerente a fim de persuadir um determinado público.

Podemos notar no trecho supracitado que a proposição de um novo conhecimento perpassa por práticas epistêmicas distintas, tais como, a problematização de um fenômeno ou objeto investigado, a retomada e análise de dados e informações, a exploração de hipóteses e concordância entre variáveis e teorias, a avaliação de condições de contorno e, finalmente, a construção de explicações em sua forma sistematizada e justificada.

Especificamente no âmbito do ensino de ciências, promover a argumentação é uma estratégia que aproxima os estudantes da prática científica e de sua natureza. É nesse espaço que os estudantes encontram espaço para propor hipóteses e testá-las por meio da concatenação de justificativas, aderindo a diferentes opiniões e compartilhando conceitos e pontos de vista eles estão se aproximando de ações do próprio fazer científico. Não se trata de um processo de recriação da ciência em sala de aula, mas sim uma forma para desenvolver habilidades cognitivas de maneira responsiva que, além de favorecerem compreensões sobre conteúdos científicos, podem ser extrapoladas e generalizadas para outras situações.

Diante dessas considerações fica evidente que, mesmo com definições distintas, o que se concebe como argumentação converge para o fato de que ela é um processo interativo. A questão da interação no processo argumentativo é decorrente da necessidade da emissão de justificativas para suportar um determinado ponto de vista. São as justificativas que conferem força e validade ao produto em construção podendo ser incorporadas ao argumento por meio de ações orais ou produções escritas, por pessoas situadas em diferentes contextos que articulam diferentes evidências, sejam de natureza teórica ou empírica. Por isso, cuidamos em definir argumentação como um ato discursivo plural que se caracteriza como um processo pelo qual um individuo, ou grupo de pessoas, buscam tornar claro um determinado fenômeno, situação ou objeto, por meio da emissão de alegações que, invariavelmente, são suportadas por justificativas $e$ outros elementos que the conferem validade perante uma determinada audiência. 


\subsubsection{A ARGUMENTAÇÃO NO ENSINO DE CIÊNCIAS}

Argumentação é uma prática epistêmica central em ciências (DUSCHL et al., 2007) e entendemos que seja fundamental para promover a Alfabetização Científica que haja o planejamento de atividades e sequências de ensino que promovam o desenvolvimento dessa habilidade nos estudantes.

Incluir a argumentação como uma prática comum ao ensino de ciências é algo que é bem aceito e está completamente difundido entre a comunidade de pesquisadores de educação em ciências, pois vários trabalhos estruturam metodologias e planejamentos de sequências de ensino que tem como um dos objetivos ensinar explicitamente argumentação aos estudantes (por exemplo, ERDURAN et al., 2004; JIMÉNEZ-ALEIXANDRE; ERDURAN, 2008; McNEILL, 2011).

Jiménez-Aleixandre e Erduran (2008), com base na sintese de resultados oriundos de diferentes pesquisas que versam sobre argumentação, organizam benefícios obtidos pela introdução dessa prática no ensino de ciências. As autoras destacam cinco itens, que são denominados de "potenciais contribuições da argumentação" (Tabela 2.1).

Tabela 2.1. - Potenciais contribuições da argumentação quando introduzidas no ensino de ciências. (adaptado de JIMÉNEZ-ALEIXANDRE; ERDURAN, 2008, p.6)

\begin{tabular}{l} 
POTENCIAL CONTRIBUIÇÃO DA ARGUMENTAÇÃO \\
\hline Evidenciar e caracterizar processos cognitivos \\
Desenvolver competências comunicativas e pensamento crítico \\
Alcançar alfabetização científica; falar e escrever ciência \\
Enculturação científica; desenvolvimento de critérios epistêmicos \\
Desenvolvimento de raciocínio e critérios lógicos \\
\hline
\end{tabular}

De acordo com o que é apresentado por estas autoras, promover a argumentação no ensino de ciências, entre outras coisas, explicita os processos cognitivos dos estudantes, favorecendo o desenvolvimento de habilidades comunicativas e o pensamento crítico.

Ainda nessa proposição, emerge o fato de que a argumentação colabora para o avanço da Alfabetização Científica dos estudantes, uma vez que estes são inseridos em um ambiente em que precisam "falar" e "escrever" ciência, o que ocasiona o desenvolvimento de raciocínios e critérios lógicos essenciais para se atingir os objetivos almejados. 
McNeill (2011), assim como Duschl et al. (2007), defende que a argumentação deve ser trabalhada no ensino de ciências desde os anos iniciais, pois quando os estudantes estão engajados em situações argumentativas, são favorecidos a construírem de maneira crítica múltiplas explicações, a fazerem uso de evidências que apoiem suas alegações e que, consequentemente, facilitam a construção de entendimentos sobre ciência.

Para Simon et al. (2006), ser capaz de compreender e utilizar de técnicas e habilidades da argumentação em situações de natureza científica é o cerne para o avanço da Alfabetização Científica.

Essa preocupação em trabalhar a argumentação em sala de aula deixa evidente o caráter positivo que pesquisas da área de ensino de ciências depositam nessa prática, pois, como dito, a argumentação tem todo um caráter dialógico, interativo e colaborativo incorporado a ela. No entanto, conforme destacado por Berland e Reiser (2009), se queremos que os alunos se engajem em práticas de construção do conhecimento por meio de práticas argumentativas, “(...) então temos que entender como as explicações são construídas e o contexto social que faz com que esta prática seja significativa" (p.27, tradução nossa). Desse modo, configura-se uma nova questão fundamental ao entendimento sobre o contexto em que esta pesquisa se insere: Como as características do ensino por investigação podem possibilitar o surgimento da argumentação e o aprendizado dos alunos?

\subsection{ESPAÇO INTERATIVO DE ARGUMENTAÇÃO COLABORATIVA}

A ciência é uma prática social e os conhecimentos científicos são produzidos coletivamente por meio de proposições de novas ideias e construção de novos modelos e teorias que possuem incorporadas em si aspectos históricos, sociais e econômicos do período em que foram desenvolvidos, uma vez que cientistas e pesquisadores carregam consigo valores culturais que variam de acordo com o meio do qual fazem parte. Nessa perspectiva, é coerente defender que a ciência é construída também por meio da argumentação. É a partir do momento em que se é exposto um argumento à comunidade e ao público em geral, que é possível avaliar as conjecturas e a validade das explicações propostas. 
Schwarz (2009) destaca que a argumentação pode ser dialética ou dialógica. Para o primeiro caso, argumentar consiste em uma ação na qual o indivíduo que a está desenvolvendo faz relações entre diferentes fontes de conhecimento por meio de movimentos que fortalecem ou enfraquecem o status epistêmico do argumento que está sendo produzido. Em outras palavras, a argumentação dialética pode ser concebida como uma ferramenta discursiva, cuja forma particular fornece uma estrutura de apoio e organização para examinar, avaliar e elaborar diferentes ideias para se construir uma explicação. Para o caso dialógico, argumentação induz funções, de proponente ou oponente, que proporcionam o avanço das alegações por meio de interações sociais. Leitão (2007) descreve que no âmbito das relações dialógicas, estabelecer ligações entre conclusões e justificativas pode ser caracterizado como um processo de múltiplas perspectivas avaliativas, no qual distintas formas utilizadas para significar uma alegação se opõem e se entrecruzam durante os processos comunicativos de maneira responsiva e interativa entre pares.

No caso do ensino de ciências, o caráter dialógico da argumentação ganha destaque devido às interações entre os membros e elementos que constituem a sala de aula durante a resolução de um determinado problema e/ou construção de entendimento sobre algum fenômeno, principalmente em aulas que se baseiam em estratégias investigativas nas quais o ato de argumentar possui um papel privilegiado para o aprendizado de conteúdos científicos pelos estudantes.

Um dos princípios fundamentais de uma abordagem dialógica é a negociação de significados que ocorre durante o compartilhamento de ideias e, consequentemente, gera a construção de conhecimento de maneira colaborativa.

No contexto da sala de aula, permitir aos estudantes que se apropriem da prática de argumentação, além de aproximá-los dos diversos aspectos da epistemologia da ciência e do trabalho científico, favorece que eles construam seus entendimentos individualmente por um processo de interação no qual há, em primeira instância, o compartilhamento de compreensões. São os processos de interação entre os membros e componentes que constituem a sala de aula (professor, estudantes e materiais didáticos) que colocam em evidência o papel formativo proporcionado pelo desenvolvimento da argumentação durante o aprendizado dos estudantes.

O caráter formativo das interações no processo argumentativo é o que proporciona a construção de entendimento pelos estudantes e está estreitamente associado à negociação de significados dos conteúdos científicos que estão sendo 
investigados. No contexto de uma abordagem investigativa, a construção de sentidos e significados é promovida, então, devido à configuração de um espaço interativo de argumentação colaborativa, ou seja, um ambiente onde a argumentação progride conforme o professor medeia interações de diferentes niveis entre seus alunos e dados teóricos e empíricos que se têm disponíveis, tornando a construção de argumentos algo colaborativo, conforme são apresentadas explicações ao objeto investigado.

Em aulas investigativas o aprendizado é favorecido por meio de interações de diferentes naturezas podendo ser compreendido como um processo que visa à apropriação de conteúdos e construção de entendimento sobre ciência pelos estudantes. É nessas interações eles têm acesso a diferentes alegações e suas concepções e explicações são exploradas e avaliadas à luz de eventuais refutações ou pontos de vistas discordantes.

Na dinâmica interativa da argumentação dialógica, as tomadas de posição que surgem ao longo do diálogo são respostas aos atos de significação que as antecederam e, ao mesmo tempo, demandam e convocam respostas subsequentes (LEITÃO, 2007). Nessa perspectiva, a construção de conhecimento é mais interessante e instigante para um aluno quando ele está imerso num processo argumentativo, uma vez que é na relação com os pares que o entendimento sobre diferentes conteúdos são ressignificados.

No ensino por investigação é papel do professor propor um problema de investigação e criar condições para que seus alunos se engajem em seu processo de resolução. É a partir da proposição de um problema que os alunos iniciam a busca por construção de explicações e, também, é nesse momento que se iniciam as primeiras interações. Nesse sentido, o professor deve estar atento para possibilitar o envolvimento de seus alunos a proposta por meio de diferentes tipos de ações. Essas ações tenderão a culminar em diversos tipos de interações, sejam entre os indivíduos que compõe a sala de aula, professor-aluno ou alunoaluno, ou entre os elementos e recursos didáticos utilizados naquele momento, como, por exemplo, os materiais didáticos e intelectuais disponíveis.

Os significados são criados na interação social e internalizados individualmente. A aprendizagem ocorre por meio da negociação de significados em um ambiente que confronta diferentes perspectivas sobre um mesmo objeto. Este processo é constituído por diversos tipos de interações, por exemplo, as discursivas que são promovidas, estabelecidas e conduzidas em sala de aula pelo professor, que por sua vez utiliza de uma grande variedade de discursos com o 
objetivo de possibilitar a construção de significados pelos seus alunos (MORTIMER; SCOTT, 2002).

Uma ampla gama de conteúdos está relacionada às interações promovidas no contexto do ensino por investigação. Essas interações permitem que sejam evidenciadas no processo dialógico desde as questões procedimentais, no que tange ao trabalho com dados e informações, até questões ligadas à epistemologia do trabalho científico, como a argumentação.

São as interações que, portanto, permitem que os alunos escutem uns aos outros, discutam ideias, reflitam sobre o que observam à luz das informações que possuem disponíveis. Ou seja, o processo argumentativo depende dessas interações para ocorrer e faz parte do trabalho do professor mediar, conduzir e intervir durante a ocorrência de uma investigação em sala de aula.

A discussão que se iniciou nesta seção, defende claramente o papel da interação. Intuitivamente, pode-se pensar que a interação pressupõe a colaboração, mas é necessário ter atenção quanto a essa inferência.

De acordo com Andriessen (2006), quando os estudantes se engajam em práticas argumentativas na sala de aula, eles estão construindo conhecimento colaborativamente por meio da troca de informações favorecidas durante a interação com seus colegas, com seu professor e com os materiais intelectuais aos quais têm acesso, tais como livros didáticos, exposições orais, resultados de experimentos e até mesmo observações de fenômenos cotidianos. Andriessen (op. cit.) defende que a argumentação pode ajudar os estudantes a atingirem uma grande variedade de objetivos educacionais almejados por propostas e documentos oficiais, pois argumentar com o intuito de aprender envolve os estudantes na elaboração e compreensão de conceitos e estimula tanto o raciocínio lógico como a reflexão crítica.

Compreendemos que colaboração é resultante de qualquer interação em que há troca de pensamentos, ideias, pontos de vistas, informações, etc., entre diferentes indivíduos que tenha um propósito comum. Ou seja, colaborar está diretamente relacionado ao compartilhamento de compreensões entre diferentes sujeitos com o intuito de construir entendimento sobre determinada situação, fenômenos, objeto ou conceito.

O trabalho colaborativo possui um potencial positivo à forma de os estudantes pensarem, agirem, interagirem e resolverem problemas. Nesse sentido, por terem como ponto de partida a proposição de um problema para investigação, as abordagens investigativas adquirem um papel privilegiado na 
ocorrência de colaboração entre os alunos, pois o professor não só propõem um problema, mas também promove distintos tipos de interações com e entre seus alunos, viabilizando o compartilhamento e a emergência de múltiplos pontos de vistas e explicações sobre um mesmo objeto.

É comum em sala de aula os alunos restringirem sua participação emitindo resposta às perguntas feitas pelo professor, que por sua vez, emite uma avaliação sobre o que foi dito. Esse padrão de interação, denominado por I-R-A (Indagação do professor - Resposta do aluno - Avaliação do professor), é amplamente discutido na literatura da área de educação e é frequentemente associado a um ensino tradicional no qual os alunos não são estimulados a participarem criticamente do processo de aprendizagem em que estão inseridos já que suas contribuições acabam sendo pontuais e necessárias apenas para preencher lacunas existentes no discurso no professor. Todavia, é necessário ter cautela ao se tecer críticas negativas sobre esse tipo de padrão de interação. Por maior que seja o grau de liberdade conferido aos alunos, é o professor que determina o conjunto de conteúdos que serão explorados ao longo de um período letivo, devido a isso e por ser autoridade epistêmica em sala de aula, é também o responsável por propor problemas que permitam que seus alunos construam entendimentos sobre esses diferentes conteúdos.

A presença de perguntas é algo inevitável em qualquer tipo de abordagem, mas no ensino por investigação estas possuem algumas especificidades. Machado (2012) agrupou os diferentes tipos de perguntas feitas pelo professor durante a resolução de um problema em aulas investigativas em quatro categorias, a saber: perguntas de problematização, perguntas sobre dados, perguntas exploratórias sobre o processo e perguntas de sistematização. Os diferentes tipos de perguntas feitas pelo professor, conforme estruturado por Machado (op. cit.), refletem suas intenções nas etapas de uma investigação e almejam possibilitar que os alunos desenvolvam olhares e posturas ativas no processo de construção de entendimento sobre conteúdos e conceitos científicos. Nesse sentido, o que difere uma abordagem investigativa de uma abordagem expositiva, por exemplo, é que os alunos são convidados não só a apresentarem em suas respostas valores numéricos ou definições de conceitos, mas, sim, dados, informações, evidências e explicações sobre o objeto de investigação.

É por meio do direcionamento ocasionado pelas perguntas do professor que os alunos dão respostas relacionadas a diferentes elementos que compõem a resolução do problema que está em investigação por meio de um processo de 
colaboração. É neste momento de colaboração mútua que os alunos trazem a discussão dados, evidências e outros suportes às ideias que buscam defender, avaliam e corrigem eventuais visões equivocadas ou que não possuem fundamento científico emitido pelos colegas e se apropriam de gêneros discursivos semelhantes ao do professor e da ciência enquanto corpo de conhecimento.

As avaliações feitas pelo professor, por fim, não se resumem àquelas de natureza binária, sim/não, certo/errado, mais/menos, etc. São essas avaliações que permitirem que a investigação e construção de entendimento pelos estudantes sobre o objeto investigado sejam aprofundadas e aproximadas das explicações aceitas pela ciência.

Diante de todo esse panorama, o processo dialógico desencadeado no curso de uma investigação em sala de aula ocasiona não só o surgimento de respostas às perguntas do professor, mas a emergência de elementos distintos que constituirão os argumentos dos alunos. É por meio de questionamentos que serão suscitados dados, garantias, justificativas que validam e qualificam conclusões. Do mesmo modo, não é esperado que todos esses componentes sejam emitidos por apenas um aluno. É dentro do contexto de múltiplas interações promovidas numa abordagem investigativa que se configurará o quadro de argumentação colaborativa.

A título de sintese, é válido ressaltar que quaisquer grupos de pessoas compartilham suas ideias e opiniões utilizando-se da argumentação, estejam estas no trabalho ou em distintos contextos sociais, pois frequentemente necessitam defender seus pontos de vista e isso requer que eles argumentem competentemente com seus pares. A argumentação tende a ocorrer no discurso natural de um indivíduo, sendo assim, promover um espaço interativo de argumentação colaborativa permite que os estudantes desenvolvam distintas habilidades argumentativas, bem como a articular as estruturas de um argumento. Dessa forma, ensinar ciências por meio da argumentação pode ajudar os estudantes a desenvolverem consciência social, principalmente em momentos em que acatam ou refutam ideias advindas dos colegas ou outras fontes distintas. Essa prática tende a possibilitar também que os estudantes façam uma melhor tomada de decisões em contextos fora do âmbito escolar, pois desenvolvem capacidades relacionadas a avaliação de múltiplas evidências e pontos de vista, o que está de acordo com os pressupostos da Alfabetização Científica. 
Argumentar para aprender requer um número expressivo de interações. Nesse sentido, limitando-nos ao contexto da sala de aula, o espaço de aprendizagem precisa ser propício para o surgimento de interações entre os estudantes para que então estes possam construir seus entendimentos sobre conceitos e fenômenos científicos por meio dessa prática. Esse ambiente deve permitir interações sociais e discursivas, ser interativo, pois como apontado por Vigotski (2004) para um avanço expressivo do desenvolvimento cognitivo de um indivíduo é necessário que ocorram interações sociais, compartilhamento de saberes e, ainda, que haja a presença de complementos de complexidade superior.

É nas interações com os pares que os estudantes acessam diferentes saberes, evidências e têm suas habilidades lógicas e meta-cognitivas estimuladas. Nesse sentido, argumentar se torna uma forma de aprendizado colaborativo, uma vez que a busca por compreensões sofisticadas sobre a ciência e a construção de seus próprios entendimentos ocorre pela ampliação de uma rede conceitual que ganha consistência conforme, durante a dinâmica proporcionada pelas interações, são incorporadas (ou refutadas) ideias, evidências e justificativas pela contribuição dos demais colegas e, principalmente, pelo professor que conduz e gerencia o processo de aprendizagem.

Podemos compreender então que o conhecimento que é construído por cada estudante durante a argumentação é, também, coletivo uma vez que o conceito científico que está sendo trabalhado, enquanto está em fase de elaboração, está aberto e permite que se incorporem diferentes saberes e pontos de vistas, assim como ocorre no desenvolvimento da própria ciência.

\subsection{O PAPEL DO PROFESSOR NA PROMOÇÃO DA ARGUMENTAÇÃO}

Apesar de estar presente em situações cotidianas, a argumentação, quando restrita ao ambiente da sala de aula, tende a não surgir espontaneamente. Torna-se então fundamental que sejam planejadas estratégias apropriadas que favoreçam o seu surgimento e desenvolvimento em situações de aprendizagem.

Conforme De Chiaro e Leitão (2005) destacam, os conteúdos sobre os quais se argumenta, ou seja, passiveis de argumentação, geralmente são 
questões abertas que necessitam de solução e que, por não estarem resolvidas, estão sujeitas à discussão. Sendo assim, a argumentação dificilmente não estará presente durante o processo de construção de conhecimentos, conceitos e significados, porque na maioria das situações investigativas trabalhadas em aulas de ciências o problema a ser resolvido por meio da investigação possibilita a emergência de múltiplas soluções a serem fornecidas e elaboradas pelos estudantes.

O ensino por investigação é uma abordagem que possui características que facilitam a ocorrência de interações argumentativas entre os estudantes e, nesse sentido, as Sequências de Ensino Investigativas adquirem uma posição privilegiada no processo de ensino e aprendizagem de conteúdos científicos, pois, além de facilitarem o surgimento de interações, aumentam a possibilidade de o professor atuar como mediador e não como agente puramente transmissor de conhecimento.

No entanto, mesmo com vários aspectos positivos associados ao ensino por investigação, apenas trabalhar a investigação de um fenômeno ou situação problema com os estudantes não é suficiente para que a argumentação ocorra. Em um espaço em que se almeja a construção do conhecimento por processos argumentativos, o professor é fundamental para gerar e gerenciar as interações argumentativas dos estudantes, pois se ele não desempenhar um papel ativo frente à investigação que está sendo realizada, pouco provavelmente ele conseguirá estabelecer um espaço interativo de argumentação colaborativa e, consequentemente, facilitar o aprendizado de seus alunos.

Não se trata de uma simples mudança de objetivos de ensino e da postura docente, no qual o professor deixa de lado a exposição de conteúdos e de solicitar respostas prontas de seus alunos, mas sim uma mudança em suas práticas no sentido de possibilitar interações e a emissão de distintos conceitos e concepções que são carregados pelos estudantes para que sejam confrontados e articulados de forma a se aproximarem de conhecimentos legitimados pela ciência.

Ainda de acordo com De Chiaro e Leitão (op. cit.), "a argumentação pressupõe a possibilidade de mudança nas perspectivas adotadas por quaisquer dos participantes a respeito do tema discutido" (p. 351). Essa afirmação evidencia um dos obstáculos recorrentes na mudança da prática docente, que reside no fato de que os professores, considerados socialmente como detentores e divulgadores de conceitos e conteúdos legitimados, durante situações argumentativas que visam à construção do conhecimento, dificilmente se 
colocam na posição de um interlocutor a ser convencido. Isso não quer dizer que o professor deva se colocar como um sujeito ingênuo que faz afirmações parcas sobre conteúdos científicos para que seus alunos tenham facilidade em contestá1o, mas sim que ele esteja disposto e disponivel para discutir a validade de um conhecimento aceito socialmente, possibilitando ao longo desse processo de interações que seus estudantes compreendam características específicas relacionadas à própria construção do conhecimento sobre o conceito que está em discussão.

Dúvidas e momentos de impasse entre os estudantes na resolução de uma situação problema são comuns no intercurso de uma investigação. Há ocasiões em que os estudantes simplesmente não conseguem desenvolver raciocínios, fundamentar justificativas ou estabelecer relações entre variáveis que lhe estão disponíveis, pois não conseguem acessar premissas e conhecimentos anteriores que possuem de maneira adequada ou até mesmo desconhecem as bases necessárias para a resolução do problema que estão investigando.

Nessa perspectiva, Lidar et al. (2006) afirmam que o desenvolvimento de uma aula, seja ela experimental ou não, é positivamente afetado quando o professor fornece intencionalmente pequenas informações relacionadas à prática investigativa e ao conteúdo científico explorado aos seus alunos. Essas informações podem ser de naturezas distintas, mas sucintamente ajudam os estudantes a estabilizarem suas ideias e a compreenderem melhor os instrumentos intelectuais com os quais estão trabalhando, seja em nivel técnico, com relação ao manuseio dos conteúdos e aparatos que lhes estão disponíveis, ou em nível epistêmico, relacionado à construção de significados e estabelecimento de relações entre observações, dados, evidências e conclusões.

Desse modo, recai ao professor a tarefa de promover a continuidade da investigação, impedir que os estudantes se dispersem e que o envolvimento e o compromisso possibilitado por esse espaço não seja perdido, por meio do fornecimento de pistas intencionais aos estudantes, como sugerido pelos autores acima, e/ou por meio de outras ações didáticas e pedagógicas.

Conforme destacam De Chiaro e Leitão (2005),

o processo de apropriação do conteúdo curricular depende significativamente da mediação do professor na medida em que suas ações discursivas conferem estatuto epistêmico ao discurso dos alunos. (...) É necessário que um processo social e comunicativo de apropriação de um conteúdo preexistente 
aconteça e para isso, o papel do professor (...) torna-se fundamental. (p.357)

Em situações de interação argumentativa, recorrentes em aulas investigativas, o professor assume a posição de autoridade central na dinâmica de uma investigação realizada na sala de aula de ciências, pois é ele quem propõe os problemas e conduz seus alunos na discussão e compreensão dos fenômenos ou conceitos que estão em estudo.

Dadas essas características, a postura ativa que deve ser assumida pelo professor evidencia que, no contexto das investigações e da argumentação, ele também se torna responsável por mediar o conhecimento aos seus alunos, promovendo o desenvolvimento de habilidades típicas da cultura científica nos mesmos, as quais os instrumentalizam com ferramentas e práticas fundamentais para que tracem caminhos para a solução de problemas, escolares ou até mesmo de outros contextos.

Finalmente, os estudantes, quando imersos em um ambiente interativo de argumentação colaborativa, fornecem hipóteses que são testadas e investigadas com o intuito de se construir entendimento sobre a situação problema que se almeja explicar. Para que o conhecimento seja construído, as hipóteses devem adquirir o status de conclusões, sendo assim, emerge a necessidade de o que o professor, mediador, tenha total conhecimento sobre o argumento que está em debate durante a investigação que está conduzindo. A clareza do conteúdo científico e, por consequência, do argumento e da explicação a serem estruturados durante o processo investigativo, é o que deve orientar o professor nas ações a serem desempenhadas e perguntas a serem proferidas em busca da evidenciação dos dados relevantes a resolução do problema pelos seus alunos, na elaboração de condições de contorno e das refutações que sustentarão o entendimento sobre o fenômeno investigado. 


\section{INVESTIGANDO O PROCESSO ARGUMENTATIVO}

Apresentaremos nesse capitulo uma revisão da literatura sobre diferentes formas de analisar as ações tomadas por um professor que têm potencial em instaurar situações argumentativas e desenvolver a argumentação de seus alunos. Iniciaremos apontando formas de identificação das situações argumentativas em sala de aula. Em seguida, buscaremos explicitar como que essas situações podem ser promovidas e, finalmente, apresentaremos nossa ferramenta analítica construída para atender nossos objetivos.

\subsection{INVESTIGANDO ARGUMENTAÇÃO E ARGUMENTO}

No âmbito desta pesquisa, almejamos compreender alguns aspectos que circundam a prática da argumentação em aulas investigativas. Para isso, a fim de nortear a nossa investigação e busca de resultados que possam contribuir para a área de educação em ciências, colocamos, ainda no capítulo 1, a seguinte questão: Quais ações tomadas pelo professor promovem o surgimento e desenvolvimento da argumentação pelos estudantes no contexto do ensino por investigação?

Responder a essa questão exige não só a organização das ideias ofertadas por diferentes pesquisadores, mas também a adoção e utilização de ferramentas metodológicas adequadas para investigação dos processos argumentativos que podem ocorrer em sala de aula, especificamente, em aulas pautadas nas características do ensino por investigação que é a preocupação premente deste trabalho.

É relevante destacar que, apesar de nosso objetivo compreender quais são e como se desenvolvem as ações tomadas por um professor que promover argumentação, devemos também dedicar esforços para construir entendimento sobre a capacidade de os estudantes elaborarem argumentos. Sendo assim, para alcançarmos resultados de maior proficuidade consideramos que são duas as 
principais variáveis que despontam em nosso estudo: (1) quais são os argumentos elaborados pelos estudantes e (2) como ocorreu o processo pelo qual estes argumentos foram construídos.

Pesquisas que dedicam esforços para mapear, compreender e fazer inferências sobre uso e a promoção da argumentação em sala de aula, bem como sua contribuição para o aprendizado dos estudantes, utilizam de diferentes ferramentas metodológicas para coletar e analisar seus dados, geralmente oriundos de situações empíricas de sala de aula.

Há uma vasta gama de metodologias utilizadas para se obter resultados provenientes desses tipos de dados. Todavia, mesmo diante dessa diversidade de estratégias metodológicas que podem ser encontrada na literatura, há tempos que o principal referencial utilizado pelos trabalhos relacionados à argumentação no ensino de ciências é a obra Os Usos do Argumento de Stephen E. Toulmin (1958/2006).

Toulmin foi um filósofo e sua obra, publicada pela primeira vez em 1958, foi elaborada com o intuito de discutir e compreender se há e quais são os modos apropriados de criticar e avaliar uma determinada asserção.

Com relação a essa asserção propriamente dita, o autor destaca que:

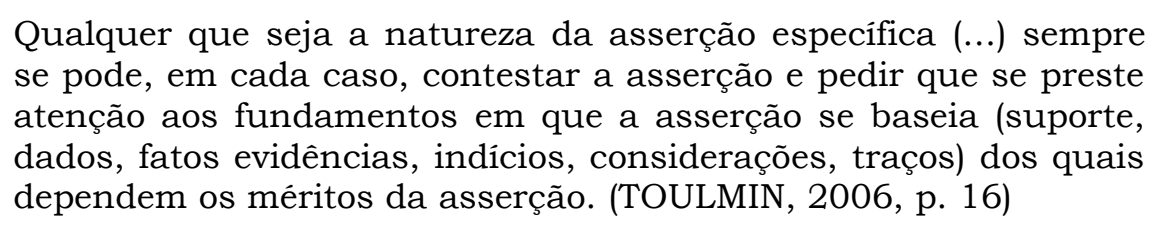

Diante do exposto podemos inferir que, devido ao fato de toda asserção ser contestável, faz-se necessária a elaboração de argumentos, denominados pelo autor como "justificatórios", que dão validade aos posicionamentos que são proferidos por um indivíduo. É sobre esses argumentos, ditos justificatórios, e suas características que toda a obra de Toulmin é centrada, pois, conforme menciona, "podemos produzir argumentos justificatórios de muitos tipos (...)" (p. 19).

A proposição de Toulmin é feita com base no pressuposto de que, fora do contexto da lógica formal, os argumentos não podem ser enquadrados em formas semelhantes as do silogismo aristotélico que indica que toda afirmação válida é gerada com base em uma conclusão que advém da ligação entre premissas 
menores e premissas maiores. Diante disso, o autor se dispõe a verificar e caracterizar elementos que podem ser comuns a todos os tipos de argumentos.

É partindo dessas conjecturas que Toulmin elabora o seu layout dos argumentos que consiste em um padrão estrutural no qual um argumento pode ser enquadrado. Esse seu modelo, conhecido na literatura como Padrão de Argumento de Toulmin (TAP, abreviação de Toulmin's Argument Pattern, termo oriundo do idioma inglês), entre beneficios e facilidades metodológicas de pesquisa, permite que seja feita conferência de maior ou menor validade às alegações que são proferidas ao longo de um processo de argumentação e ilustra a natureza dos argumentos à luz de seis elementos complexos interligados entre si: dado (D), conclusão $(\mathrm{C})$, garantia $(\mathrm{W})$, apoio $(\mathrm{B})$, qualificador $(\mathrm{Q})$ e refutador (R). ${ }^{4}$

Como dito, Toulmin inicia sua proposição destacando que no processo de argumentação toda asserção proferida defende uma alegação. Fatos que apoiam esta alegação são os dados que, por sua vez, são subsídios que suportam uma conclusão.

É valido mencionar que a conclusão, no sentido estabelecido pelo autor, não possui um caráter finalizado, como é comumente interpretado em nosso idioma. Este elemento carrega o papel de alegação ou afirmação que compõe a asserção que está sendo apresentada. Nesse momento, com intuito de minimizar eventuais polissemias, ressaltamos que a trataremos como uma afirmação ou alegação apresentada publicamente para a aceitação ou contestação de uma determinada audiência.

Com relação ao argumento como um todo, quando estruturado de acordo com seu modelo, Toulmin expõe que:

Para haver um argumento é preciso apresentar dados de algum tipo; uma conclusão pura, sem quaisquer dados apresentados em seu apoio, não é um argumento. Mas o apoio das garantias que invocamos não tem de ser explicitado, pelo menos para começar; as garantias podem ser aceitas sem desafio, e seu apoio pode ser deixado subentendido. (2006, p.152)

Frente a essa declaração, torna-se evidente que, para ele, a garantia possui um papel fundamental em um argumento. $\mathrm{O}$ valor da garantia reside no

\footnotetext{
4 Os valores apresentados entre os sinais gráficos “( )" representam abreviações dos termos precedentes e correspondem a primeira letra de palavras correlatas no idioma inglês.
} 
fato de que este é um elemento que permite compreender de que modo o dado e a conclusão se relacionam. As garantias são caracterizadas como “(...) regras, princípios, licenças de inferência ou o que quisermos, desde que não sejam novos itens de informação" (p. 141). São elas que autorizam a passagem dos dados à conclusão e, devido as suas várias formas possiveis, “(...) podem conferir diferentes graus de força às conclusões que justificam” (p. 144).

Devido ao seu caráter justificatório, muitas vezes apenas a presença de uma garantia possibilita que se obtenha um argumento, dito, satisfatório, como destaca o próprio autor: Uma vez que se empregue a garantia correta, qualquer argumento
pode ser apresentado na forma 'dados; garantia; logo, conclusão',
e, portanto, com a garantia correta qualquer argumento torna-se
formalmente válido. Ou seja, se se escolhem as palavras
adequadas, qualquer argumento pode ser expressado de tal modo
que sua validade seja evidente simplesmente por sua forma; (...)
(p. 171)

No entanto, como nem sempre as garantias proferidas são suficientes para tornar um argumento válido ou aceito, Toulmin considera e incorpora outros três componentes em seu modelo estrutural.

O apoio (ou conhecimento básico, conforme descrito em alguns trabalhos nacionais) que representa generalizações de explicações. É usado em casos particulares da elaboração de um argumento e está associado diretamente às garantias a quem conferem maior força e autoridade.

O refutador, ou condição de exceção, é um elemento que, em oposição ao apoio, “(...) indica circunstâncias nas quais se tem de deixar de lado a autoridade geral da garantia” (p.145), ou seja, faz com que a garantia perca força. São eles, os refutadores, que geralmente contestam diferentes suposições criadas pelas garantias e expressam situações e contextos em que o argumento não pode ser tomado como válido.

Preocupado em descrever casos em que dado, conclusão, garantia e apoio não são suficientes para tornar um argumento válido a depender da forma que o refutador se relaciona a esses elementos, Toulmin ainda propõe a existência de um último componente, denominado qualificador. São os qualificadores que indicam e explicitam a força conferida pela garantia à conclusão e, grosso modo, podem ser compreendidos como um advérbio que dá aval à alegação obtida ou, 
nas palavras do próprio autor, representa a "força que a garantia empresta a conclusão" (p. 153).

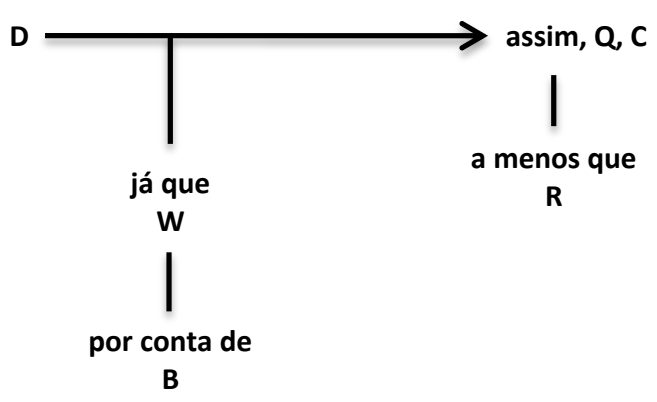

Figura 3.1 - Estrutura de um argumento conforme proposto por Toulmin (2006, p. 150).

A interconexão entre D, C, W, B, R e Q pode configurar um argumento, na sua forma mais completa, representado na forma de um diagrama como o da Figura 3.1, que é frequentemente encontrado na literatura.

Dado as SEIs como o contexto de nossa pesquisa e as discussões realizadas nas seções anteriores, acreditamos que usar o Padrão de Argumento de Toulmin como uma ferramenta metodológica para análise de possíveis argumentos proferidos pelos estudantes incorreria em resultados bastante proficuos.

Julgamos importante destacar nesse ponto que utilizaremos o modelo de Toulmin de duas formas distintas: 1) Para procurar argumentos construídos pelos alunos em uma determinada situação de investigação; e 2) para qualificar o argumento que se almeja atingir como objetivo de uma aula, considerando suas particularidades.

A escolha por essas formas de utilização do TAP é decorrente da frequente forma como um argumento é encontrado nas falas dos alunos. Em uma investigação realizada em sala de aula, notamos ser frequente o aparecimento de argumentos que são menores (mais sucintos, mas não necessariamente com menor qualidade) e restritos a uma determinada situação de investigação. No entanto, no que diz respeito ao objetivo da aula e das conclusões que se almeja que os alunos construam sobre o objeto de investigação, também há argumentos maiores, que se refere aos objetivos que o professor quer atingir ao longo da aula. 


\subsection{DIFERENTES USOS DO PADRÃO DE TOULMIN}

Apesar de ter sido originado para estudos do campo jurídico, o modelo de Toulmin é bastante difundido em outros domínios, como, por exemplo, na comunicação, filosofia e, assim como no âmbito dessa pesquisa, no contexto da educação em ciências. Suas contribuições e uso em diferentes áreas revelam que há certa facilidade ocasionada pelo TAP ao processo de análise de situações argumentativas, principalmente pelo seu caráter prescritivo que permite identificar o que é e o que não é um argumento (ERDURAN, 2008).

No entanto, apesar das diversas contribuições positivas, algumas pesquisas apontam limitações do modelo, principalmente quando este é utilizado como uma ferramenta metodológica de pesquisa. Com base em um levantamento bibliográfico feito com o intuito de discutir fundamentos metodológicos utilizados por estudos de argumentação em aulas de ciências, Erduran (2008) destaca que, em primeira instância, adotar o TAP facilita não só a identificação, mas também a compreensão do que seja um argumento e quais são os componentes que fazem parte de sua estrutura.

Apesar da facilidade ocasionada pelo modelo enquanto ferramenta metodológica de pesquisa, Erduran também revela que sua simplicidade é uma via de mão dupla, pois no processo de análises de situações empíricas o TAP também ocasiona uma grande dificuldade para os pesquisadores distinguirem seus componentes e associá-los às asserções dos estudantes.

Complementar aos apontamentos de Erduran (2008), Nascimento e Vieira (2008), assim como Sasseron e Carvalho (2011b), evidenciam outras limitações do TAP, como, por exemplo, o fato de que ele não leva em consideração o contexto em que a construção do argumento foi realizada, o que ocasiona um problema metodológico quando se almeja identificar garantias válidas nas falas e contribuições dos membros que compõe o processo argumentativo.

Outros implicadores mencionados por esses pesquisadores estão relacionados ao fato de que é dificil usá-lo para identificar argumentos construídos coletivamente e que, além disso, no contexto da sala de aula, nem sempre as asserções proferidas pelos estudantes seguem a sequência "dado, garantia, logo conclusão" conforme apresentada por Toulmin, dificultando a caracterização da argumentação, principalmente em tempo real durante o processo de ensino e aprendizagem. 
Diversas explicações podem ser fornecidas para justificar a "incompletude" do padrão de argumento de Toulmin, mas, acreditamos, assim como ressaltado por Nascimento e Vieira (2008), que

(...) as limitações apontadas do padrão são mais fruto da sua utilização fora do campo que Toulmin inicialmente lhe deu ao concebê-lo do que propriamente devido a lacunas que o filósofo tenha deixado dentro do seu campo de concepção. (p. 17)

Mesmo com suas limitações, o TAP é bastante popular em pesquisas da área de educação em ciências, sendo utilizado para a investigação de argumentos escritos e orais produzidos pelos estudantes individualmente, em pequenos grupos ou coletivamente em um processo de colaboração com os colegas de sala de aula.

Ao longo do processo de investigação de situações argumentativas em sala de aula, há também uma variação no que se refere à forma como o TAP é utilizado como ferramenta de análise. Apesar de sua forma original permitir a compreensão de diferentes características e elementos de argumento, não é pequena a quantidade de trabalhos que o associam a outras ferramentas metodológicas (por exemplo, JIMÉNEZ-ALEIXANDRE et al., 2000) ou o modificam de forma a adequá-lo aos interesses de pesquisa e situação de ensino que se almeja investigar (por exemplo, ERDURAN et al., 2004).

A associação do padrão de Toulmin à outra ferramenta metodológica sugerida por Jiménez-Aleixandre et al. (2000), por exemplo, foi feita devido ao o objetivo da pesquisa em questão: estudar interações em sala de aula. Durante a análise de seus dados empíricos, esses pesquisadores observaram situações em que o TAP não era suficiente para caracterizá-los, diante disso, obtiveram suas conclusões acerca de seus dados com o auxílio de outros dois conjuntos de categorias: um relacionado especificamente à argumentação, denominado Práticas Argumentativas, e o outro, estruturado com base em fontes teóricas dos campos da epistemologia e filosofia da ciência, história e ecologia, denominado Operações Epistêmicas.

Com relação às modificações sugeridas ao TAP que podem ser encontradas na literatura, Erduran et al. (2004), assim como Zohar e Nemet (2002 apud ERDURAN, 2008), devido à dificuldade de se caracterizar D, W e B nas falas dos estudantes, agruparam esses componentes em uma única categoria para 
contornar problemas de confiabilidade e validade que estariam associados ao TAP durante o processo de análise de situações empíricas.

O trabalho de Erduran et al. (2004), que tinha como um dos objetivos fazer um estudo qualitativo da argumentação dos estudantes, também articulou o TAP de uma maneira que possibilitou estabelecer niveis de qualidade aos argumentos proferidos pelos estudantes em uma aula que abordava uma temática sociocientifica. $\mathrm{Na}$ proposta desses autores, os argumentos poderiam ser enquadrados entre os níveis 1 e 5 , sendo que o argumento mais sofisticado, ou seja, o de nível 5, compreenderia os casos em que os argumentos são compostos por mais que um refutador e os argumentos menos sofisticados, de nível 1, compreenderiam aqueles que são compostos por apenas uma alegação dada em resposta a outra alegação (Tabela 3.1).

A justificativa dada por esses autores a esta proposta está calcada no pressuposto de que se os estudantes utilizam e explicitam diferentes refutadores em suas falas significa que eles compreenderam e dominam tanto o conteúdo sobre o qual estão trabalhando, bem como práticas argumentativas, como, por exemplo, o uso de evidências para sustentar suas alegações e confrontar contraargumentos.

Tabela 3.1 - Quadro analítico utilizado para avaliar a qualidade da argumentação dos estudantes em uma atividade sociocientífica proposto por Erduran et al. (2004)

\begin{tabular}{cc}
\hline $\begin{array}{c}\text { NÍVEL DO } \\
\text { ARGUMENTO }\end{array}$ & DESCRIçÃo \\
\hline $\mathbf{1}$ & $\begin{array}{c}\text { Consiste em argumentos que são simplesmente uma alegação versus uma } \\
\text { contra-alegação ou uma alegação versus outra. }\end{array}$ \\
$\mathbf{2}$ & $\begin{array}{c}\text { Argumentos consistindo em uma alegação versus outra, ambas com dados, } \\
\text { garantias ou apoios, mas nenhuma com refutação. }\end{array}$ \\
$\mathbf{3}$ & $\begin{array}{c}\text { Apresenta argumentos com séries de alegações ou contra-alegações, ambas } \\
\text { com dados, garantias ou apoios, ocasionalmente com refutação fraca }\end{array}$ \\
$\mathbf{4}$ & $\begin{array}{c}\text { Argumentos com um refutador claramente identificável. Tal argumento pode } \\
\text { ter várias alegações e contra-alegações. }\end{array}$ \\
$\mathbf{5}$ & Argumentos extensos com mais de um refutador. \\
\hline
\end{tabular}

As modificações e influências do modelo de Toulmin nos trabalhos da comunidade vão além de alterações metodológicas para análises qualitativas ou quantitativas de recortes empíricos decorrentes de situações de ensino em sala de aula. McNeill et al. (2006), por exemplo, utilizaram as ideias de Toulmin na 
organização de materiais didáticos elaborados para auxiliar professores a apoiarem seus alunos na construção de explicações científicas 5 .

No discurso desses autores é colocado em primeiro plano o objetivo de "ajudar os estudantes a construírem explicações sobre fenômenos nos quais eles justifiquem suas conclusões usando evidencias apropriadas e princípios científicos" (McNEILL et al., 2006, p.155, tradução nossa), pois, de acordo com o levantamento bibliográfico que realizaram, os estudantes têm dificuldades de articular e defender suas alegações e conclusões à luz de dados e evidências adequados.

Diante desse propósito, é dedicado esforços em favorecer e aprimorar as explicações científicas dos estudantes na forma escrita. Para isso, eles também adotaram o Padrão de Argumento de Toulmin, alegando que esse modelo está bastante próximo das recomendações feitas pelas propostas oficiais, utilizadas como referência nas escolas do país onde desenvolvem suas pesquisas.

Ao criarem uma estratégia didática que se ancorava nas ideias de Toulmin, fizeram simplificações do modelo original. O modelo da estratégia que desenvolveram desmembrava uma explicação científica, tal qual haviam definido previamente, em três componentes: conclusão, evidência e raciocínio.

A conclusão é caracterizada pelos autores, assim como na proposta de Toulmin, como uma alegação feita em resposta a uma determinada questão ou problema. A depender da questão que se almeja resposta, a conclusão pode servir para elucidar e identificar fatores causais entre as variáveis da situação em estudo ou ser descritiva, no sentido de que descreve o porquê ocorreu o fenômeno.

\footnotetext{
5 McNeill et al. (2006) compreendem que argumento e explicação são produtos distintos, mas que as práticas epistemológicas da ciência utilizam de ambas para gerar seus produtos. Com o intuito de se alinharem com as propostas curriculares estadunidenses que dão grande ênfase ao ensino por investigação e facilitar o acesso de professores e estudantes à prática de argumentação, ou seja, construir conclusões à luz de evidências, esses pesquisadores optam por utilizar o termo "explicações científicas". Grosso modo, esses autores consideram que um argumento em ciência é equivalente a uma explicação científica. Em oposição a essa concepção. Osborne e Patterson (2011) afirmam que um dos objetivos da produção de explicação é engajar os estudantes na construção do conhecimento e que, devido ao caráter pragmático do argumento, no qual se parte de premissas para se estabelecer conclusões, este tem um senso de direcionamento. Mesmo sendo uma questão pertinente, a discussão sobre o que é argumento e explicação, bem como algumas das implicações que a diferenciação desses atos discursivos tem para o ensino de ciências e pesquisas em educação não será abordada neste trabalho. Todavia nossa concepção sobre essa temática pode ser consultada em Ferraz e Sasseron (2013).
} 
Por sua vez, as evidências são representadas por dados ou conceitos que apoiam a conclusão proferida e podem ser de diferentes naturezas, como, por exemplo, dados numéricos ou estatísticos, observações, fatos e conceitos científicos.

O raciocínio, por fim, explicita porque determinados dados podem ser compreendidos como evidências e como estas apoiam a conclusão a ser defendida. O termo raciocínio, da forma como é definido, possui características da garantia do modelo de Toulmin, quando este é empregado com a função de autorizar a passagem das evidências à conclusão, e do apoio, quando se refere a conceitos científicos utilizados para justificar uma determinada conclusão. Em outras palavras, podemos dizer que, na proposta de McNeill et al. (2006), garantia e apoio são fundidos em um único elemento, sendo esta ação justificada pelo fato de que o objetivo desses pesquisadores é diminuir o número de componentes de um argumento para tornar situações argumentativas e os elementos teóricos que podem constitui-las mais familiar aos professores e estudantes.

Com os avanços dos estudos que realizavam e preocupados com a questão da qualidade das explicações científicas dos estudantes, assim como Erduran et al. (2004), em um trabalho posterior Krajcik e McNeill (2009) dedicaram atenção ao componente refutador e o incorporaram ao modelo inicial. Nesta proposta complementar, o refutador, diferentemente da descrição de Toulmin, descreve explicações alternativas e fornece evidências, contra evidências e raciocínios sobre o porquê uma alegação pode não ser apropriada ou pode não ser aceita.

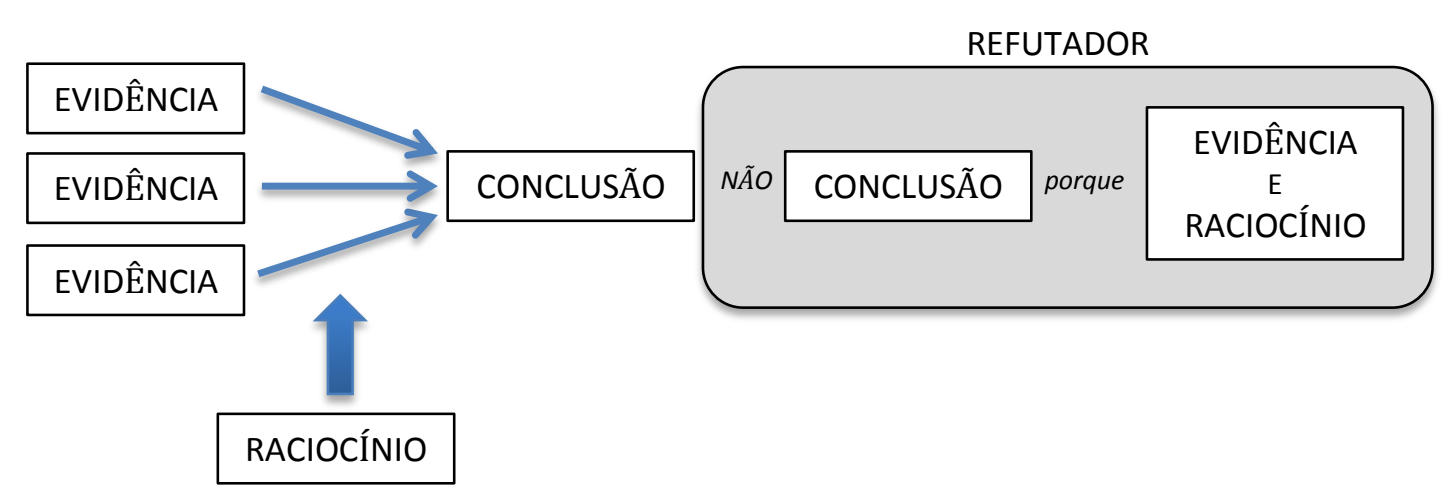

Figura 3.2 - Simplificação do Padrão de Argumento Toulmin para facilitar o acesso de professores e estudantes a prática de construir explicações científicas proposto por Krajcik e McNeill (2009). 
A figura 3.2. ilustra como esses quatro componentes se interconectam, destacando como as evidências apoiam a conclusão, o raciocínio fornece justificação para que se haja ligação entre a conclusão e as evidências e, finalmente, como a refutação considera e exclui explicações alternativas para um determinado fenômenos científico sob investigação.

A ênfase que é dada a um ou outro componente do modelo de Toulmin nos trabalhos de McNeill e colaboradores é dependente dos objetivos da pesquisa em questão. No entanto, privilegiar a análise de um ou outro elemento do argumento pode não explicitar características essenciais ao processo de argumentação que se almeja em sala de aula. Sendo assim, destacamos novamente nesse ponto que é necessário sempre levar em conta o contexto e o meio pelo qual ocorreu a argumentação bem como os produtos que são gerados nesse processo.

\subsection{SURGIMENTO E DESENVOLVIMENTO DA ARGUMENTAÇÃO}

Discutimos ao longo do capítulo 2 que o professor desempenha um papel fundamental durante a implementação de aulas que têm seus alicerces ancorados no ensino por investigação, pois é ele quem favorece o surgimento de interações e situações argumentativas entre os alunos. Nesse sentido, é razoável inferir que o sucesso de uma atividade investigativa, ou de uma SEI, é dependente das ações do professor. Ou seja, apenas adotar uma abordagem investigativa não é suficiente para garantir a participação dos estudantes no processo de argumentação, bem como a construção ativa de entendimento acerca dos temas e tópicos que estão sendo abordados.

Como mencionado, as Atividades Investigativas, bem como as SEIs tal qual proposto por Carvalho (2011a; 2013), ocasionam um status privilegiado ao surgimento da argumentação, mas, por serem dependentes de múltiplos aspectos da cultura escolar e das interações entre os membros da sala de aula, é preciso dedicar esforços para compreender como o professor, responsável pelo surgimento e manutenção dessas interações, desempenha seu papel.

Há uma breve lacuna na literatura no que diz respeito aos referenciais teóricos que se dedicam a compreender quais ações tomadas por um professor em sala de aula geram interações argumentativas entre estudantes. Outra relação pouco discutida é como a argumentação se relaciona com o ensino por investigação. Diante disso julgamos necessário salientar distintos pontos de vista 
para fundamentar uma ferramenta metodológica de pesquisa adequada para investigar o que estamos nos propondo com esse trabalho.

Promover a argumentação em aulas de ciências não é tarefa fácil, principalmente por não estarmos habituados a um modelo de ensino em que os estudantes, juntamente com a mediação do professor, avaliam distintos enunciados e explicações sobre um determinado fenômeno ou conceito científico, validam hipóteses e estabelecem conclusões dotadas de apoios e garantias.

Nesse sentido, diferentes abordagens e metodologias de ensino são propostas com o intuito de facilitar o surgimento de argumentação dos estudantes, mas também é necessário compreender como o professor pode atuar nesse processo.

Considerando que o padrão de argumento proposto por Toulmin como um dos principais mecanismos para estudos sobre argumentação, alguns trabalhos dedicam grandes esforços em aproximar os professores de estratégias e metodologias de ensino que se baseiam nesse modelo, como, por exemplo, McNeill e Krajcik (2009) que, como já mencionado, elaboraram uma ferramenta que adaptava de forma simplificada os termos do TAP para torná-lo acessivel a professores do ciclo básico com quem trabalhavam.

É relevante destacar que, estamos preocupados com o processo de construção de argumentos em aulas investigativas, e como propuseram Sasseron e Carvalho (2011a), acreditamos que com o auxílio do TAP e outras ferramentas metodológicas de pesquisa, é possivel compreender alguns padrões comuns de argumentação dos estudantes. Outro ponto é que, no contexto do ensino por investigação é reforçada a perspectiva de que o processo de aprendizagem apesar de ser favorecido por práticas argumentativas, argumentar não é e não deve ser uma prática a ser ensinada explicitamente.

Sasseron e Carvalho (2011b), por meio da análise de diferentes episódios oriundos de aulas investigativas, planejadas e implementadas conforme descrito por Carvalho (2011a; 2013), propuseram a existência de um ciclo argumentativo nas falas dos alunos e professor, a partir da relação entre o modelo de Toulmin e os indicadores de Alfabetização Científica. Estes indicadores representam ações e habilidades próprias da comunidade científica que são utilizados pelos alunos durante uma investigação e resolução de um problema e, nas palavras das próprias autoras, “(...) tem a função de nos mostrar algumas destrezas que devem ser trabalhadas quando se deseja colocar a AC em processo de construção entre os alunos" (Sasseron e Carvalho, 2011a, p. 338). A Tabela 3.2 explicita 
quais são os indicadores de AC e como eles se relacionam com o processo de investigação que ocorrem ao longo da implementação da aula de uma SEI.

Tabela 3.2 - Indicadores de Alfabetização Científica proposto por Sasseron e Carvalho (2011a).

\begin{tabular}{lc}
\hline \multicolumn{1}{c}{ INDICADORES DE AC } & BREVE SíNTESE \\
\hline Seriação de informação & Relacionados ao trabalho com dados empíricos, possibilita que \\
Organização de Informação & $\begin{array}{l}\text { se compreenda a situação ou assunto que está sendo } \\
\text { Classificação de informação }\end{array}$ \\
investigado. & $\begin{array}{l}\text { Relacionados com a obtenção de dados e delimitação de } \\
\text { Teste de hipótese }\end{array}$ \\
$\begin{array}{l}\text { variáveis, possibilita a explicitação aspectos relevantes à } \\
\text { solução do problema investigado. }\end{array}$ \\
Justificativa & $\begin{array}{l}\text { Relacionados ao entrecruzamento de variáveis e informações; } \\
\text { Previsão }\end{array}$ \\
pxplicação & acerca do tópico. \\
Raciocínio lógico & Relacionados a apropriação das ideias em caráter científico; \\
Raciocínio proporcional & possibilita compreensão das relações entre dados e \\
& conclusões em nível epistemológico. \\
\hline
\end{tabular}

$\mathrm{Na}$ explanação das autoras buscou-se relacionar quais são os elementos discursivos presente na construção de argumentos orais proferidos por alunos de uma turma de Ensino Fundamental 1 durante a resolução de problemas investigativos. Após análise de distintos episódios empíricos, foi possível caracterizar a forma como a argumentação dos estudantes se desencadeou e a maneira como as relações entre diferentes dados e variáveis foram estabelecidas durante o processo de interação entre professor e aluno.

A ideia de ciclo argumentativo envolve a forma como ocorreu a divulgação da construção do entendimento de um conceito ou tema pelos alunos e é descrito como "(...) a forma por meio do qual as argumentações se desencadeiam e a maneira como as relações entre diferentes dados e variáveis são estabelecidas." (Sasseron e Carvalho, 2011a, p. 111).

Sucintamente, na proposta das autoras esse ciclo é formado por de três etapas. A primeira etapa está relacionada a posse das informações oriundas do processo de investigação. É nesse momento inicial em que os dados são suscitados e organizados convenientemente de forma a tornar explícita a sua importância durante o processo de investigação.

Num segundo momento, há o trabalho com dados e informações. Uma vez coletados os dados, começam a se definir as variáveis relevantes para obtenção do entendimento do conceito ou assunto abordado. No decorrer dessa etapa, são proferidas as primeiras hipóteses pelos estudantes e, a mediação do professor e 
interação dos colegas, possibilita não só conexões entre diferentes dados, mas a construção do espaço relevante para a investigação.

Em sua etapa final, o ciclo argumentativo chega às explicações propriamente ditas. Nesse momento todos os entrecruzamentos de dados e as construções feitas anteriormente são suscitados, permitindo a elaboração de construções lógicas, objetivas e racionais entre causa e efeitos.

A ideia da presença de um ciclo que marca a argumentação dos estudantes durante a resolução de uma situação-problema por um processo de investigação advém, como dito, da relação entre os indicadores de AC e os componentes do padrão de argumento de Toulmin feita pelas autoras para tornar explícita sua proposição.

É relevante destacar nesse ponto que, ainda que o ciclo argumentativo tenha sido apresentado em etapas, essas não são estanques. As autoras deixam claro que durante o processo de investigação estas etapas comumente aparecem sobrepostas, pois a construção de entendimento sobre o fenômeno ou conceito investigado tende variar de aluno para aluno.

Tabela 3.3 - Relação entre os indicadores de AC e os componentes do Padrão de Argumento de Toulmin proposto por Sasseron e Carvalho (2011a).

\begin{tabular}{ll}
\hline \multicolumn{1}{c}{ INDICADORES DE AC } & \multicolumn{1}{c}{ COMPONENTE DO TAP } \\
\hline $\begin{array}{l}\text { Seriação de informação } \\
\text { Organização de informação } \\
\text { Classificação de Informação } \\
\text { Levantamento de hipótese }\end{array}$ & Conhecimento Básico (B) \\
$\begin{array}{l}\text { Teste de hipótese } \\
\text { Explicação }\end{array}$ & $\begin{array}{l}\text { Dado (D) } \\
\text { Justificativa }\end{array}$ \\
$\begin{array}{ll}\text { Conclusão (C) } \\
\text { Previsão }\end{array}$ & $\begin{array}{l}\text { Garantia (W) } \\
\text { Refutador (R) }\end{array}$ \\
\hline
\end{tabular}

A tabela 3.3 destaca como os indicadores de alfabetização científica se relacionam com os componentes do TAP e nos permite lançar um olhar mais criterioso sobre como se dá o processo argumentativo no intercurso de uma atividade de investigação.

A ideia expressa pelas autoras desvelam comportamentos médios, ou seja, apesar da relação estabelecida entre indicadores e os componentes do TAP, interconexões distintas das apresentadas podem ser encontradas na dinâmica 
argumentativa em sala de aula. Com base na leitura destas relações, podemos observar que o trabalho com as informações que os alunos dispõem, possibilita que sejam evidenciadas características do conhecimento básico, pois são sobre esses dados e informações que será ancorada as argumentações posteriores. É nesse momento que os estudantes tem a possibilidade de perceberem $\mathrm{e}$ compreenderem quais são as variáveis relevantes à construção de solução ao problema investigado e como elas se relacionam entre si.

Feito esse trabalho inicial com os dados e informações, abre-se precedentes para que as primeiras alegações comecem a ser proferidas pelos estudantes. O processo de relacionar dados com alegações é oriundo de ações relacionadas aos indicadores explicação, levantamento e teste de hipóteses, pois é nesse momento em que se começa a revelar relações construídas pelos estudantes, o que permite inferir que eles estão desenvolvendo suas compreensões acerca do assunto discutido.

Obviamente que relacionar dado e conclusão não descreve o processo argumentativo em sua completude. É apenas após a análise macro que se pode legitimar o argumento. Sendo assim, o trabalho com as garantias, refutadores e qualificador também é essencial nesse processo.

O uso pelos estudantes do indicador justificativa marca o estabelecimento de garantias ou condições de exceção, segundo o padrão de Toulmin. É nesse momento, quando se autoriza a passagem dos dados a conclusão que se pode validar o processo argumentativo como um todo.

Por fim, os qualificadores estão diretamente relacionados ao indicador previsão, pois é essa ação que além de se estabelecer com referência as hipóteses permite dar aval a conclusão obtida e, consequentemente, estabelecer o peso do argumento construído.

Com relação aos indicadores raciocínio lógico e raciocínio proporcional, apesar das autoras não terem feito nenhuma referência direta a eles, compreendemos que ambos se engendram por todo o processo argumentativo, uma vez que estão diretamente associados às práticas epistêmicas e apropriação do conhecimento em caráter científico. 


\subsection{FORMAS DE PROMOVER A ARGUMENTAÇÃO}

Compreender como se dá o processo argumentativo no contexto do ensino por investigação é, de fato, um passo fundamental a esta pesquisa, mas se almejamos que a argumentação seja uma ação frequente no ensino de ciências é preciso ter clareza sobre quais aspectos são relevantes para o desencadeamento dessas situações. O professor então assume o papel central nesse processo e, por isso, nessa seção buscaremos descrever algumas contribuições da área no que diz respeito a promoção da argumentação e do posicionamento ativo dos estudantes frente ao aprendizado e construção de entendimentos.

Em um trabalho recente, Pimentel e McNeill (2013), com o intuito de compreender como engajar os estudantes na prática da fala científica, propõem que há determinados movimentos nas falas do professor que viabilizam e promovem uma postura ativa dos estudantes no processo interativo de aprendizado (Tabela 3.4). Compreendemos que esses movimentos são fundamentais para que os estudantes se sintam acolhidos e estimulados a expressarem seus pontos de vistas, compreensões e avaliarem diferentes enunciados proferidos sobre um determinado tema ou conceito científico.

Tabela 3.4 - Movimentos de um professor para a promoção de interação e engajamento dos alunos na fala científica (PIMENTEL; McNEILL, 2013).

\begin{tabular}{ll}
\hline \multicolumn{1}{c}{ MOVIMENTO } & \multicolumn{1}{c}{ DESCRIÇÃO } \\
\hline Elaborar & $\begin{array}{l}\text { Professor elabora e fornece uma explicação extensa ou aplicação da breve } \\
\text { contribuição dada na forma de resposta pelo aluno. }\end{array}$ \\
Interromper & $\begin{array}{l}\text { Professor interrompe o aluno antes de ele terminar sua resposta. } \\
\text { Provar }\end{array}$ \\
$\begin{array}{l}\text { Professor solicita ao aluno expandir sua resposta, pedindo mais explicações e } \\
\text { esclarecimentos. }\end{array}$ \\
$\begin{array}{l}\text { No lugar de avaliar, o professor pede aos demais alunos da turma que } \\
\text { comentem a resposta dada por alguém. }\end{array}$ \\
\hline
\end{tabular}

O pressuposto dessas autoras é que, uma vez que a interação entre estudante-estudante é estimulada, estes serão favorecidos a desenvolverem uma postura mais crítica e ativa frente aos conteúdos que lhes são apresentados, permitindo que estruturem seus conhecimentos seguindo padrões semelhantes aos da própria ciência.

Apesar da argumentação dos estudantes não ser o foco da pesquisa de Pimentel e McNeill (2013), vemos dois movimentos epistêmicos que nos 
forneceram pistas importantes sobre as ações do professor e que possuem características que se relacionam aos nossos propósitos: Provar e Lançar de volta.

O processo de argumentação dos estudantes exige que eles sejam capazes de elaborar hipóteses, relacionando-as com dados de diferentes naturezas e estabelecendo garantias que corroborem as alegações que forneceram. Sendo assim, compreendemos que quando o professor solicita que os estudantes provem seu ponto de vista, ou seja, reformulem suas respostas de forma a dar mais clareza e sentido ao que estão alegando, está vinculado ao processo de justificação de conclusão. Do mesmo modo, para que os estudantes possam se posicionar, sentindo-se acolhidos a julgarem distintos enunciados, o professor necessita dar espaço para que isso ocorra. Nesse caso, ao lançar de volta um questionamento dos estudantes ajuda no favorecimento de interações e participação ativa no processo de construção de ideias.

Nossos apontamentos estão em consonância com as conclusões das próprias autoras que atentam para o fato de que é essencial que se encoraje os estudantes à participação no processo de investigação e construção de significados que é possibilitado e favorecido nesse contexto.

Em uma pesquisa que teve a argumentação como protagonista, Simon et al. (2006) preocupados em caracterizar como os argumentos produzidos por estudantes e quais as ações do professor promoviam a argumentação dos mesmos, utilizaram de dados empíricos oriundos da implementação de uma atividade de cunho sociocientífico e elaboraram códigos e categorias para identificar o que eles denominaram "processos argumentativos".

$\mathrm{Na}$ ocasião em que coletavam seus dados de pesquisa, os professores com quem esses autores trabalharam receberam formação sobre os conteúdos científicos e teóricos que circundavam a atividade a qual lhes serviram de corpus de estudo. Os objetivos nesse trabalho eram fazer um mapeamento dos argumentos proferidos pelos estudantes adotando o TAP como modelo e posteriormente, a depender da quantidade e da qualidade dos argumentos que haviam sido construídos, caracterizar como os professores engajavam seus alunos em práticas relacionadas à argumentação e quais foram às ações realizadas durante esse processo.

A análise das falas e atuação dos professores permitiu aos pesquisadores a sistematização da tabela 3.5, dotada de códigos específicos que estão inseridos em categorias mais amplas. 
Tabela 3.5 - Códigos e categorias para identificação de processos argumentativos, dispostos em uma tentativa hierárquica. (SIMON et al., 2006).

\begin{tabular}{|c|c|}
\hline $\begin{array}{l}\text { CÓDIGOS PARA AS INTERAÇÕES DOS } \\
\text { PROFESSORES QUE REFLETEM OS } \\
\text { OBJETIVOS DA ARGUMENTAÇÃO }\end{array}$ & $\begin{array}{l}\text { CATEGORIAS DE PROCESSOS } \\
\text { ARGUMENTATIVOS REFLETIDOS } \\
\text { NAS INTERAÇÕES DO PROFESSOR }\end{array}$ \\
\hline $\begin{array}{l}\text { Encoraja a discussão } \\
\text { Encoraja ouvir }\end{array}$ & Falar e escutar \\
\hline $\begin{array}{l}\text { Define argumento } \\
\text { Exemplifica argumento }\end{array}$ & Saber o que significa argumento \\
\hline $\begin{array}{l}\text { Encoraja ideias } \\
\text { Encoraja posicionamento } \\
\text { Valoriza posições distintas }\end{array}$ & Posicionar-se \\
\hline $\begin{array}{l}\text { Confere evidências } \\
\text { Fornece evidências } \\
\text { Incita o uso de justificativa } \\
\text { Enfatiza a justificativa } \\
\text { Encoraja aprimoramento de justificativa } \\
\text { Faz-se de advogado do diabo }\end{array}$ & Justificar com evidências \\
\hline $\begin{array}{l}\text { Utiliza ou disponibiliza exemplos escritos } \\
\text { Oferece/apresenta posturas a serem seguidas }\end{array}$ & Construir argumentos \\
\hline $\begin{array}{l}\text { Encoraja avaliação } \\
\text { Avalia argumentos } \\
\text { Processo - usa de evidências } \\
\text { Conteúdo - natureza da evidência }\end{array}$ & Avaliar argumentos \\
\hline $\begin{array}{l}\text { Encoraja a antecipação a contra-argumentos } \\
\text { Encoraja o debate }\end{array}$ & Contra argumentar/debater \\
\hline $\begin{array}{l}\text { Encoraja reflexão } \\
\text { Pergunta sobre mudança de opiniões }\end{array}$ & Refletir sobre o processo argumentativo \\
\hline
\end{tabular}

As categorias são bastante claras em suas definições principalmente devido aos códigos que estão contidos nela. Além disso, estão organizadas de maneira hierárquica, de modo que, de acordo com a proposta de Simon et al. (2006), a prática argumentativa em uma atividade sociocientífica é inserida de forma gradativa e, em sua maioria, linearmente.

Caracterizar a argumentação dos estudantes como uma atividade que ocorre por meio de ações que se desenvolvem de forma hierárquica, pode até ter algum sentido no contexto das atividades sociocientíficas sobre as quais estes autores se preocuparam. Todavia, considerando que temos trabalhado em um ambiente de ensino por investigação, a busca pelas categorias propostas nas falas de um professor tende a ser incoerente com os nossos objetivos. Devemos lembrar que, em nosso contexto, os tópicos colocados em discussão possuem conclusões já estabelecidas e legitimadas enquanto componente de um corpo de 
conhecimento, diferentemente das questões sociocientificas que são controversas e, na maioria das vezes, não possuem respostas únicas e/ou corretas.

Leitão (2011), fora do contexto das questões sociocientíficas e preocupada principalmente em compreender como a argumentação favorece a reflexão e construção de conhecimento por um individuo, destaca diversas relações entre ações argumentativas e desenvolvimento cognitivo e propõe categorias gerais que, se instauradas, permite a construção de argumentação em sala de aula.

Antes de descrever suas categorias, a autora evidencia que para ocorrer argumentação é necessário ter atenção à forma como os tópicos curriculares serão apresentados pelo professor aos seus alunos, pois nenhum tema é polêmico ou discutivel por si só. Nesse sentido, gerar uma discussão em torno de um determinado tópico depende do modo como o discurso será realizado. Frente a essa premissa são listadas distintas ações discursivas que favorecem o surgimento da argumentação, tornando-os tópicos a serem abordados, ditos canônicos, em temas de argumentação.

As ações apresentadas por Leitão (2011) são organizadas em três grupos distintos: o primeiro, denominado ações no plano pragmático, engloba ações que criam condições para que haja o surgimento da argumentação, pois são elas que criam possibilidade de discordância sobre os tópicos a serem abordados e abre precedentes ao debate de pontos de vistas dos estudantes, característica essencial à interações argumentativas; o segundo grupo incorpora ações discursivas em no dito plano argumentativo, pois são essas que sustentam e expandem a argumentação iniciada pelo professor no plano anterior, abrindo precedentes à formulação de argumentos e contra-argumentos; por fim, no terceiro grupo se enquadram as ações no plano epistêmico, pois são essas as ações que legitimam o conhecimento construído durante o processo argumentativo, trazendo conteúdos, procedimentos e formas de raciocínio típicas do corpo de conhecimento em questão.

A tabela 3.6 sintetiza os três grupos propostos pela autora e apresenta alguns exemplos de quais são os tipos de ações típicas que se enquadram neles. Vale ressaltar que apesar de serem apresentadas individualmente, as ações dos planos pragmático, argumentativo e epistêmico, diferentemente das categorias de Simon e colaboradores (2006), frequentemente surgem entrelaçadas devido ao fluxo contínuo do discurso em sala de aula, sendo possivel, em diversos momentos, encontrar em uma única fala do professor mais de uma das ações descritas. 
Tabela 3.6 - Ações discursivas que favorecem o surgimento da argumentação em distintos níveis. (LEITÃO, 2011)

\begin{tabular}{|c|c|}
\hline $\begin{array}{c}\text { PLANOS } \\
\text { DISCURSIVOS }\end{array}$ & AÇÕES TÍPICAS TOMADAS PELO PROFESSOR \\
\hline Pragmático & $\begin{array}{l}\text { Desafiar os alunos para que formulem pontos de vista } \\
\text { Pedir justificação para pontos de vista apresentados } \\
\text { Colocar o aluno na posição de oponente } \\
\text { Estimular o aluno para que (re)examine seus pontos de vistas à luz de } \\
\text { contra-argumentos } \\
\text { Estimular que o aluno responda a contra-argumentos }\end{array}$ \\
\hline Argumentativo & $\begin{array}{l}\text { Formular e/ou avaliar argumentos } \\
\text { Formular e/ou avaliar dúvidas, objeções e contra-argumentos } \\
\text { Responder às objeções }\end{array}$ \\
\hline Epistêmico & $\begin{array}{l}\text { Apresentar conteúdos relacionados ao tema } \\
\text { Demonstrar de procedimentos específicos da área do conhecimento } \\
\text { Ensinar habilidades } \\
\text { Oferecer formas de raciocínio da área de conhecimento } \\
\text { Legitimar pontos de vista dos alunos }\end{array}$ \\
\hline
\end{tabular}

Uma análise atenta das ações discursivas propostas tanto por Leitão (2011) como por Simon e colaboradores (2006), nos permite inferir que em um ambiente que se almeja o aprendizado por meio da argumentação o professor deve ter como objetivo central encorajar seus alunos a formularem pontos de vistas, bem como a escutarem e considerar opiniões distintas, o que está em consonância com as conclusões de Pimentel e McNeill (2013) acerca dos dois movimentos epistêmicos que discutimos anteriormente.

\subsection{PROPÓSITOS EPISTÊMICOS PARA PROMOÇÃO DA ARGUMENTAÇÃO}

Sintetizando algumas ideias, destacamos que ao longo de uma atividade de investigação é o professor que, ao permitir e promover situações em que ocorram interações discursivas entre os integrantes da sala de aula, oferece condições para que argumentação surja e se desenvolva. Para isso, tendo em vista os diferentes referenciais apresentados neste capitulo, compreendemos que é necessário que o professor tenha atenção não só ao trabalho com informações relacionadas ao objeto de investigação sobre o qual se almeja a construção de entendimento, mas também que se atente a práticas pedagógicas relacionadas à gestão e ao gerenciamento da turma, estimulando a participação dos alunos e interações entre os mesmos. 
Assim, acreditamos que ao longo da realização de uma investigação em sala de aula, as ações tomadas por um professor podem ser caracterizadas de forma a permitir que compreendamos como foi possivel promover e desenvolver a argumentação dos estudantes.

Destacamos nesse ponto que durante uma investigação o professor toma diferentes ações e perpassa por diferentes caminhos para garantir que os estudantes construam entendimento acerca do fenômeno ou conceito científico em discussão. Esses caminhos são guiados por propósitos distintos que instauram e conduzem a investigação, assim como a argumentação. A cada um desses propósitos, que não necessariamente ocorrem de forma isolada ou individualizada, estão associadas ações típicas tomadas pelo professor e que favorecem a participação dos estudantes no processo argumentativo.

Estas ações estão ligadas tanto a aspectos didático-pedagógicos como à epistemologia do trabalho científico e à explicitação dos pontos de vista dos estudantes ligados aos conteúdos científicos em foco durante a aula. Além disso, tais ações dificilmente ocorrem em aulas em que não há oportunidades para discussão tanto entre professor-aluno como entre aluno-aluno, pois o processo de investigação e a concatenação das ideias que podem surgir ocorrem essencialmente por meio de interações.

Em um ensaio preliminar (FERRAZ; SASSERON, 2012), foi possível caracterizar e discriminar alguns das ações utilizadas por um professor ao longo de uma atividade investigativa. As conclusões obtidas nesse trabalho possibilitaram que tivéssemos uma melhor compreensão de alguns aspectos do processo argumentativo nesse contexto. Cada uma das ações, que foram encontradas em nosso ensaio, tomadas pelo professor durante uma investigação possuem propósitos específicos associados a elas e evidenciam atitudes tanto do professor quanto dos alunos, como, por exemplo, trabalho com dados, informações e conceitos científicos, levantamento e teste de hipóteses, trabalho com variáveis relevantes ao problema de investigação, elaboração de explicações, proposição de justificativas, etc.

Destacamos que não é nosso objetivo detalhar todos os propósitos e ações de um professor durante a implementação de uma atividade de investigação, por isso nos atentaremos apenas aos que se relacionam estritamente a aspectos da argumentação dos estudantes. Dessa maneira, organizamos as ações identificadas em cinco grupos distintos denominados de Propósitos Epistêmicos para Promoção da Argumentação. A escolha do nome das categorias que estamos 
propondo se deve ao fato de, como mencionado, estão ligadas tanto à argumentação como à epistemologia do trabalho científico. A tabela 3.7 detalha quais são os propósitos que julgamos serem recorrentes em aulas investigativas e algumas das respectivas ações associadas a eles.

Tabela 3.7 - Propósitos e ações do professor para a promoção da argumentação dos estudantes em uma aula investigativa.

\begin{tabular}{ll}
\hline PROPÓSITOS EPISTÊMICOS & AÇõES TíPICAS \\
\hline Retomar & $\begin{array}{l}\text { Retoma informações } \\
\text { Retoma dados } \\
\text { Retoma conceitos }\end{array}$ \\
\hline Problematizar & $\begin{array}{l}\text { Propõe um problema } \\
\text { Problematiza uma situação }\end{array}$ \\
\hline Explorar & $\begin{array}{l}\text { Explora ponto de vista } \\
\text { Explora condições de investigação }\end{array}$ \\
& $\begin{array}{l}\text { Qualifica variáveis, objetos ou fenômenos } \\
\text { Qualifica explicações ou pontos de vista } \\
\text { Qualifica contexto de investigação }\end{array}$ \\
Sintetizar & Sintetiza informações \\
& Sintetiza explicações \\
\hline
\end{tabular}

Antes de detalhar cada um dos propósitos e suas respectivas ações é importante mencionar que não temos a expectativa de encontrar uma ordem hierárquica e cronológica, diferentemente da proposta de Simon e colaboradores (2006), pois, como já constatamos em nosso ensaio, a depender do desenvolvimento das interações e do envolvimento dos alunos com a temática, uma ação que parece marcar o início do processo argumentativo pode ser reapresentada ao final de uma investigação ou pode ser complexificada devido a novos elementos trabalhados e incorporados à discussão ao longo da construção do argumento. Outro ponto que é importante ser destacado é o fato de que não é objetivo deste trabalho explicitar todos os tipos de ações que podem ser tomadas por um professor durante um processo de investigação em sala de aula. Além de acreditarmos que isso não é possivel, almejamos traçar um panorama de como a argumentação foi promovida em sala de aula com foco nas ações docentes e não detalhar minúcias desse processo.

Retomar: Esse propósito epistêmico surge da necessidade de o professor trazer para a discussão com os alunos diferentes informações já conhecidas e necessárias para a compreensão e construção de explicações sobre a situação, o fenômeno ou objeto que está sendo investigado. Trata-se de um levantamento de 
situações, dados e conceitos que já foram trabalhados em outros momentos, sejam em outras aulas ou anos escolares. É por meio da retomada que o professor garante a tomada de consciência pelos alunos dos arcabouços necessários a construção de entendimento, que podem se tornar dados, apoios ou garantias que subsidiarão seus eventuais argumentos. Entre as ações típicas relacionadas a esse propósito estão a retomada de informações, retomada de dados e retomada de conceitos científicos, sendo que elas podem ocorrer de maneiras distintas, como, por exemplo, explicitamente exposta pelo professor (ex., "Professor: A gente viu na aula passada que duas ondas podem sofrer interferência construtiva e destrutiva.") ou por meio de questionamentos direcionados aos alunos (ex., "Professor: Lucas, o que aconteceu quando a gente aumentou a frequência das ondas no experimento?").

Problematizar: Se não for problematizado adequadamente, nem todo fenômeno pode ser considerado como algo passivel de investigação. Nesse sentido, o propósito problematizar surge em decorrência do objetivo do professor em dar a forma de problema a uma determinada situação. Consiste em proposições que tornam o objeto de estudo passivel de investigação pelos alunos. É por meio da problematização que o professor explicita situações sobre as quais eles não possuem pleno entendimento, possibilitando assim que eles ampliem seus conhecimentos, construindo novos entendimentos que necessitam da compreensão de, por exemplo, novos conceitos e explicações. Conforme descrito por Carvalho (2011a; 2013) Uma investigação só é possivel se há um problema a ser investigado. No entanto, é bastante comum que esse problema seja demasiado abstrato e complexo para que os alunos o compreendam como tal. Dessa forma, o professor pode usar de diferentes ações para atingir o propósito da problematização. É possivel que ele proponha um problema explicitamente aos alunos (ex., "Professor: Como a gente pode explicar a existência de gêmeos?”), mas a depender da complexidade da situação, é necessário que essa proposição seja feita gradativamente ao longo da aula conforme os alunos vão estruturando bases mais sólidas para a compreensão da situação. Assim, outra ação típica da problematização ocorre quando, em meio à discussão, uma dúvida ou situação é colocada pelo professor na forma de problema aos alunos (ex., "Aluna: $O$ espermatozoide atinge o óvulo, ai começa a formar o bebê; Professor: O que acontece quando dois espermatozoides fecundam o mesmo óvulo?’), ou seja, ele 
usa de um caso específico para gerar um ponto de investigação aumentando a complexidade do problema central da aula.

Explorar: Há dois vieses distintos nesse propósito: um relacionado às asserções proferidas pelos alunos ao longo da investigação sobre a situação que está sendo investigada e outro relacionado ao próprio objeto de estudo. Nesse sentido, esse propósito almeja que ocorra um melhor entendimento pelos alunos das diferentes hipóteses e explicações que foram emitidas no processo investigativo, bem como de diferentes variáveis e alterações ocasionadas devido à modificação das mesmas. No que diz respeito ao primeiro caso, a ação mais comum realizadas pelo professor é a exploração de ponto de vista e ideias dos alunos (ex., "Professor: O que você quer dizer com 'no inverno é mais escuro'?; Aluno: Que o dia é menor que a noite."). Essa ação anseia que aluno desenvolva suas asserções, explicitando raciocínios e conclusões, e, além disso, garante que os demais alunos que estão participando da discussão também compreendam com maior clareza o que está sendo exposto. Com relação ao trabalho com variáveis, a ação mais comum é quando professor testa hipóteses e explicações (ex., "Aluno: Tem passarinhos que mudam de lugar quando é inverno pra poder sobreviver...; Professor: E se ele não migrasse, eles poderiam sobreviver?"), dessa maneira se explora casos particulares que possibilita um entendimento mais aprofundado da situação investigada.

Qualificar: Muitas podem ser as hipóteses e explicações dadas pelos alunos ao longo de uma investigação. É necessário, então, que o professor as caracterize de forma que elas sejam incorporadas ao processo investigado ou descartadas por serem incoerentes ou estarem fora dos limites da investigação. Portanto, esse propósito ocorre quando o professor classifica informações trazidas à discussão, tais como dados, variáveis, objetos e fenômenos, por vezes juntamente com breve avaliações. Dessa forma, é possivel também delimitar o contexto da investigação, diminuindo o número de elementos que devem ser levados em conta durante o processo de construção de explicações e entendimento pelos alunos. A qualificação de um objeto é, geralmente, feita com base na contribuição de algum aluno ao processo de investigação, dessa forma é possível aumentar a fluidez da discussão e a utilização de termos científicos adequados (ex., "Aluno: Há duas pilhas, então agora teremos o dobro de energia passando no fio; Professor: Isso! Como temos duas fontes de tensão, a intensidade final da corrente elétrica será 
duplicada"). Outra ação típica está relacionada à delimitação do contexto de investigação e auxilia o professor a definir situações de contorno para os casos em discussão (ex., "Aluno: Só as lâmpadas têm resistência? E os fios?; Professor: O fio também oferece resistência, mas vamos considerar que estamos trabalhando com fios ideais... que não tem resistência, para não complicar muito a situação, tá?”).

Sintetizar: É comum que as respostas dadas pelos alunos sejam expostas de forma confusa e, algumas vezes, inteligiveis apenas ao professor que domina o conteúdo e tem noção das possíveis respostas que podem surgir. Isso não significa que são contribuições erradas ou ingênuas, pois podem ser importantes para a construção de entendimento da investigação em curso. Outro caso recorrente é quando uma ideia é proferida de forma fragmentada, por diferentes alunos. Assim, faz-se necessária a organização dessas informações pelo professor. Portanto, o propósito epistêmico sintetizar consiste na organização de informações e explicações importantes que foram trazidas á discussão. As ações típicas tomadas pelo professor são a sintetização de informações, quando se trata de elementos mais descritivos (ex., "Aluno: O pote que ficou aberto estragou. O que ficou fechado deixou a bolacha novinha; Professor: Quando deixamos o pedaço de bolacha no pote fechado, tinha pouco ar para os microrganismos se multiplicarem, então a bolacha não estragou como aconteceu com a do outro pote.") e a sintetização de explicações, que organiza uma explicação dada por um aluno e a torna elemento da discussão (ex., "Aluno: A comida demora mais pra estragar na geladeira porque os micróbios demoram mais pra se reproduzirem...; Professor: Em baixas temperaturas a multiplicação de microrganismos é bastante lenta então os alimentos se conservam por mais tempo na geladeira."). Um aspecto importante relacionado ao propósito sintetizar é que ele está bastante relacionado ao propósito qualificar, pois, uma vez que o professor organiza as contribuições dos alunos, ele acaba atribuindo uma avaliação a ela. 


\section{METODOLOGIA DE PESQUISA, DADOS E ALGUNS RESULTADOS PRELIMINARES}

Nesse capítulo serão apresentados os pressupostos teóricos metodológicos que nortearão a análise de nossos dados. Descreveremos os arcabouços que nos permitiram enquadrar nossa pesquisa no contexto das pesquisas qualitativas para, em seguida, detalhar o processo de coleta de dados e seleção de registros a serem analisados à luz das categorias que apresentamos anteriormente. Também serão descritos alguns resultados já obtidos, oriundos de outras pesquisas que se debruçaram sobre os mesmo dados, mas com intencionalidades e objetivos distintos dos nossos e que, de alguma forma, permitirão a obtenção de conclusões mais proficuas.

\subsection{Metodologia de Pesquisa: PRessupostos teóRICOS}

Em nossa proposta almejamos compreender nuances que circundam processos de ensino em sala de aula. Assim, colocamos frente a nossa pesquisa a seguinte questão: Quais ações tomadas pelo professor promovem o surgimento e desenvolvimento da argumentação pelos estudantes no contexto do ensino por investigação?

Para responder a tal questão, além de um esforço para e organização e compreender teorias relacionadas ao problema, é necessário adotar uma metodologia de pesquisa adequada que nos permita obter conclusões pertinentes sobre as ações tomadas pelo professor que possibilitaram o surgimento e desenvolvimento da argumentação dos estudantes, como descrito pela própria questão de pesquisa.

Dado esse delineamento inicial, nosso trabalho se enquadra no contexto das pesquisas qualitativas, uma vez que almejamos interpretar principalmente o discurso verbal do professor e, consequentemente, dos alunos, bem como suas ações realizadas em sala de aula (CARVALHO, 2011b). 
A pesquisa qualitativa, amplamente utilizada em pesquisas na área de ciências humanas, é implementada para permitir o entendimento de fenômenos sociais complexos que dificilmente podem ser acessados por meio da quantificação de dados e procedimentos estatísticos sofisticados. Seguindo essa metodologia, o pesquisador procura minimizar a lacuna entre elementos teóricos e os dados empíricos utilizando de análises que se baseiam, principalmente, na percepção e compreensão de fenômenos por meio de descrições e interpretações ancoradas em distintas teorias. De acordo com Stake (2011), qualquer tipo de pesquisas exige que se façam interpretações, mas a pesquisa qualitativa “(...) depende muito da definição e da redefinição dos observadores sobre os significados daquilo que veem e ouvem" (p. 46).

A justificação da escolha pela pesquisa qualitativa pode ser distinta, mas, conforme colocado por Strauss e Corbin (2008), a principal razão para se optar por esse método é a natureza do problema de investigação. Em nosso trabalho, os dados a serem analisados foram selecionados para nos mostrar comportamentos dos membros que compõem a sala de aula, em especial as ações tomadas pelo professor. Considerando a essência desse problema e as particularidades que circundam o contexto dos dados, a quantificação das interações discursivas não nos permitirá a obtenção de conclusões significativas no que tange a nosso intuito de responder nossa questão de pesquisa, pois pelo fato de nos atentarmos a apenas um caso dentre inúmeros possíveis, não esperamos generalizar comportamentos, mas construir um panorama que possibilite elucidar ações que possam desencadear atitudes e comportamentos específicos, no caso, a argumentação dos estudantes.

Outro ponto que justifica a nossa escolha pela pesquisa qualitativa está apoiado nas ideias de Erickson (1998) que afirma que a pesquisa qualitativa é apropriada para estudos em educação, principalmente quando se almeja "identificar as nuances do entendimento subjetivo que motiva os vários participantes; e identificar e compreender mudanças ao longo do tempo" (p. 1155, tradução nossa).

A natureza do problema é um dos primeiros motivos pela escolha da pesquisa qualitativa, mas é necessário deixar claro nossa visão do que vem a ser essa metodologia, pois, apesar de ser bastante recorrente em pesquisas da área de ciências humanas e sociais, principalmente nos estudos em educação, há divergências entre suas concepções. 
Lüdke e André (1986 apud CARVALHO, 2011b) apresentam dentro da visão etnográfica seis características da pesquisa qualitativa:

- A pesquisa qualitativa tem o ambiente natural como sua fonte direta de dados e o pesquisador como seu principal instrumento. - Os dados coletados são predominantemente descritivos. - A preocupação com o processo é muito maior do que com o produto. - A análise dos dados tende a seguir um processo indutivo. - os pesquisadores não se preocupam em buscar evidências que comprovem hipóteses definidas antes do início dos estudos. - As abstrações forma-se ou se consolidam basicamente a partir de inspeção dos dados num processo de baixo para cima. (LÜDKE e ANDRÉ, 1986, p.11-13 apud CARVALHO, 2011b, p. 24)

Conforme a discussão feita por Carvalho (2011b), referência principal adotada neste trabalho, sobre cada um dos pontos mencionados acima, nosso processo de pesquisa seguirá algumas particularidades. Primeiramente, assim como discriminado por Lüdke e André, teremos um ambiente natural como fonte de dados, em nosso caso, a sala de aula, mas o pesquisador não é o nosso principal instrumento de coleta e sim uma câmera de vídeo e gravadores de áudio, que nos permitirão fazer a coleta de imagens e falas que, posteriormente, serão transformados em dados para serem analisados de forma a nos permitir construir conclusões e respostas a nossa questão de pesquisa.

No que tange a relação entre processo e produto, em nossa análise ambos são importantes, pois direcionar a atenção apenas ao processo não nos permitiria inferir nenhum tipo de garantia às conclusões obtidas, ou seja, retomando o nosso problema de pesquisa, apesar de termos interesse central nas ações desencadeadoras de argumentação realizadas por um professor, é imprescindivel que saibamos quais são constructos elaborados pelos alunos.

O processo de análise dos dados, de fato, tende a carregar um caráter indutivo, mas não é possível afirmar que para todos os casos não há preocupação com a busca de evidências para comprovação de hipóteses. Antes mesmo do início do processo de investigação desta pesquisa, acreditamos que há ações típicas realizadas por um professor que desencadeiam a argumentação de seus alunos. Sendo assim, essas hipóteses são essenciais em nosso trabalho, pois elas orientam expressivamente o nosso olhar sobre o objeto investigado, definindo, eventualmente, o que queremos ou poderemos observar. Com isso não queremos dizer que as análises realizadas buscam apenas corroborar ou refutar hipóteses elaboradas previamente, mas que estas auxiliam no direcionamento de 
esforços a aspectos cruciais ao processo de investigação e obtenção de conclusões.

Finalmente, com relação à construção de abstrações ocorrer "de baixo para cima”, essa característica possui particularidades e não pode ser aplicada em todos os casos, como, por exemplo, no desta pesquisa. Concordamos que a análise de dados é o que permite a formação e consolidação de abstrações, mas os resultados desse processo são gerados por meio da interação entre referenciais teóricos e os diferentes dados a serem analisados.

Diferentemente da explanação de Lüdke e André e da interveniência feita por Carvalho (2011b) nas características da pesquisa qualitativa apresentadas, Strauss e Corbin (2008), sugerem que a pesquisa qualitativa é composta por três componentes principais, conforme explicitado na citação a seguir:

\begin{abstract}
Primeiro, há os dados, que podem vir de várias fontes, tais como entrevistas, observações, documentos, registros e filmes. Segundo, há os procedimentos, que os pesquisadores podem usar para interpretar e organizar os dados. Eles geralmente consistem de conceitualizar e reduzir os dados, elaborar categorias em termos de suas propriedades e dimensões, e relacioná-los por meio de uma série de declarações preposicionais. Conceitualizar, reduzir, elaborar e racionar sempre são referidos como codificação. (...) Relatórios escritos e verbais são o terceiro componente. Eles podem ser apresentados como artigos em jornais científicos, em palestras (ex.: conferências) ou livros. (p. 24, ênfase no original)
\end{abstract}

Nos passos propostos por esses autores, vemos que a pesquisa qualitativa perpassa pela tríade dados, interpretação dos dados e divulgação. Retomando o que já foi apresentado até esse ponto e apresentando parte o que será exposto nos capítulos seguintes, os dados dessa pesquisa serão oriundos de uma situação empírica de sala de aula, gravados na forma de vídeo; os procedimentos para interpretação desse material perpassou pela revisão teórica da literatura, no momento em que apresentamos diferentes trabalhos que versam sobre as variáveis relacionadas à questão de pesquisa, pela elaboração de categorias baseada na organização desse referencial teórico e que posteriormente serão utilizados na análise dos dados, já codificados, para a obtenção de conclusões. E, sendo redundante, a divulgação desse material é expressa pela própria dissertação, trabalhos de congressos e eventuais artigos científicos e que puderam ser elaborados com base nos resultados alcançados.

Finalmente, é relevante destacar que mesmo que a pesquisa de caráter qualitativo, em essência, não dê grandes enfoques na quantificação e análise 
estatística de dados, alguns dados quantitativos podem ser encarados e tratados como qualitativos, desde que estes permitam uma melhor compreensão de aspectos relacionados ao objeto de investigação.

\subsection{Os DADOS}

Tendo em consideração a natureza da nossa questão de pesquisa, é imprescindivel que os dados a serem analisados permitam a que se compreenda o contexto do objeto de investigação e, principalmente, as ações realizadas pelo professor nesse espaço. Para isso, foi implementada uma Sequência de Ensino Investigativo, conforme descrito por Carvalho (2011a; 2013) em uma escola da rede pública do estado de São Paulo, a qual nos permitiu coletar diferentes tipos de dados obtidos por meio da utilização de diversos recursos, tais como, gravações de áudio e vídeo das aulas e registros e atividades elaboradas pelos alunos durante as aulas. Posteriormente, foram realizadas transcrições das falas do professor e dos alunos de forma a facilitar a leitura desse material, bem como a explicitação de interpretações e evidências à luz de nosso problema de pesquisa e, consequentemente, a obtenção de conclusões.

\subsubsection{A SEQUÊNCIA DE ENSINO INVESTIGATIVA}

A sequência de ensino utilizada para a nossa coleta de dados foi inicialmente desenvolvida por Brockington (2005) e teve suas bases teóricas publicada na forma de dissertação de mestrado. Na proposta inicial do autor ${ }^{6}$, a sequência é composta por 52 aulas de aproximadamente 50 minutos e planejadas para serem ministradas a alunos do último ano do Ensino Médio ao longo de todo um ano letivo. Esse conjunto de aulas estava organizado em 11 blocos temáticos, a serem abordados partindo de discussões acerca do uso de modelos na Física e se encerrando com discussões sobre a dualidade ondapartícula da luz.

6 Todo o material foi elaborado com o apoio do grupo de pesquisa denominado NUPIC Núcleo de Pesquisas em Inovações curriculares, formado por professores da rede pública do estado de São Paulo e pesquisadores da Faculdade de Educação da Universidade da São Paulo.

O material completo está disponível on-line e pode ser obtido pelo site: http://www.lapef.fe.usp.br/mauricio/projetos/fmcem.htm\#, acessado em 23/02/2015. 
As propriedades e características da luz é um assunto que compõe o quadro mais amplo de Física Moderna e Contemporânea, inserido recentemente na grade curricular do Ensino Médio; os primeiros trabalhos científicos que abordavam temas relacionados a Física Moderna datam do final do século XIX e início do século XX e até o momento ainda há bastante discussão acerca da validade de suas afirmações e conclusões. Devido à contemporaneidade associada aos tópicos a serem explorados na SEI, o processo de humanização da ciência tende a ser evidenciado com maior facilidade ao longo das aulas planejadas pela SEI.

Modificações foram realizadas na proposta inicial de forma a adaptar a proposição de Brockington (2005) para que sequência pudesse ser enquadrada com maior facilidade no planejamento de aulas de um professor, para que fosse dado um maior aprofundamento nas discussões sobre o comportamento dual da luz e, principalmente, para que se adequasse a definição de Sequência de Ensino Investigativa conforme proposto por Carvalho (2011a; 2013) e aos nossos interesses de pesquisa.

Após as alterações, realizadas essencialmente por Barrelo Jr (2010) que fazia parte do mesmo grupo de pesquisa que o autor da sequência em sua forma original, o tema dualidade onda-partícula da luz foi mantido, mas a SEI passou a ser composta por 11 aulas, cada uma com um propósito e objetivo específico a ser contemplado conforme discriminado na tabela 4.1 .

Tabela 4.1 - Síntese das aulas da SEI utilizada como fonte de dados.

\begin{tabular}{|c|c|c|}
\hline & AULA & OBJETIVOS E CONTEÚDOS \\
\hline & O Universo Físico & $\begin{array}{l}\text { Apresentar a proposta aos alunos; Levantar concepções } \\
\text { prévias sobre Física e o conhecimento científico; } \\
\text { Caracterizar o conceito de trajetória para partículas e } \\
\text { ondas; Discutir o papel dos modelos na Física. }\end{array}$ \\
\hline 02 & O nascimento da Física Quântica & $\begin{array}{l}\text { Contextualizar, historicamente o nascimento da Física } \\
\text { Quântica; Apresentar aspectos históricos da Física antes } \\
\text { e depois de } 1900 \text {. }\end{array}$ \\
\hline 03 & Características da Luz & $\begin{array}{l}\text { Retomar conceitos científicos sobre a luz; Trabalhar } \\
\text { propriedades de reflexão, refração e propagação da luz e } \\
\text { a ideia de raio como modelo. }\end{array}$ \\
\hline 04 & $\begin{array}{l}\text { Modelo corpuscular de Newton } \\
\mathrm{x} \text { modelo ondulatório }\end{array}$ & $\begin{array}{l}\text { Apresentar diferentes modelos para a luz: corpuscular e } \\
\text { ondulatório; Discutir a diferença entre modelos e seus } \\
\text { domínios de aplicação. }\end{array}$ \\
\hline 05 & $\begin{array}{l}\text { Interferômetro de Mach- } \\
\text { Zehnder clássico e real } \\
\text { Interferômetro de Mach- } \\
\text { Zehnder clássico e real (virtual) }\end{array}$ & $\begin{array}{l}\text { Montar, apresentar e contextualizar historicamente o } \\
\text { Interferômetro de Mach-Zehnder (IMZ); Observar } \\
\text { padrões de interferência; Trabalho dos alunos com } \\
\text { aparatos físicos e simulação computacional do IMZ; }\end{array}$ \\
\hline
\end{tabular}


07 Modelando o IMZ

08 A matemática do IMZ

09 Construindo um interferômetro quântico
Modelagem do IMZ e organização de variáveis necessárias a esse processo.

Discutir o funcionamento do IMZ e do modelo ondulatório da luz com base na modelagem matemática do fenômeno; Modelagem matemática do IMZ.

Trabalhar a ideia de modelo quântico; Transformar o interferômetro ideal clássico em um interferômetro ideal quântico; Introdução da ideia de dualidade ondapartícula.

10 Interpretações da Mecânica Discutir as quatro interpretações da Mecânica Quântica Quântica para o comportamento dual da luz com base nos resultados e discussões anteriores relacionadas ao IMZ.

11 O sentido das coisas Discutir a natureza da Ciência e da realidade física.

O planejamento completo da SEI, disponivel no anexo A, explicita detalhadamente os objetivos de cada aula, os conteúdos a serem abordados, bem como discrimina recursos instrucionais necessários a cada momento da sequência e algumas ações pensadas para que fossem realizadas pelo professor e compreensões sobre os tópicos esperado que os alunos construam.

Ressaltamos, finalmente, que a SEI é composta por diferentes tipos de atividades investigativas, como atividades experimentais manipulativas, virtuais, de demonstração, bem como atividades de leitura de texto e discussão.

\subsubsection{COlETA DE DADOS E OS PARTICIPANTES DA PESQUISA}

A fonte de dados é oriunda da implementação da SEI apresentada anteriormente. Todas as 11 aulas foram aplicadas sempre pelo mesmo professor a duas turmas distintas de $3^{\circ}$ ano do Ensino Médio devido ao grau dos conteúdos conceituais e formalismo matemático a serem trabalhados. Cada turma era constituída por, aproximadamente, 30 alunos com idade entre 15 e 17 anos, fazia parte de uma escola da rede pública do estado de São Paulo.

$\mathrm{Na}$ ocasião da coleta de dados, o professor que aplicou a sequência, tinha 23 anos de experiência em docência e participava de um grupo de pesquisa vinculado a Universidade de São Paulo que tinha, entre outros, o interesse de pesquisa em processos de aprendizagem por meio do ensino por investigação. Com isso, salientamos que o professor tinha conhecimento sobre práticas investigativas e participou do processo de adaptação da SEI, o que favoreceu a implementação das aulas conforme o planejamento. 
As aulas foram gravadas na forma de áudio e vídeo, e todos os registros e atividades realizadas pelos alunos foram coletados de forma a compor um arsenal robusto de pesquisa. As aulas foram transcritas e organizadas em turnos de fala com o intuito de facilitar a análise, leitura e apresentação dos dados. Gestos e outras ações relevantes ao entendimento da situação também foram sinalizados nos registros.

Finalmente, destacamos que todos os participantes ou seus responsáveis autorizaram o usos registros coletados como material de pesquisa, mas, por razões éticas, os nomes e possíveis identificações dos indivíduos participantes serão substituídos por pseudônimos.

\subsubsection{OS DADOS DE ANÁLISE}

Com mencionado, ao final da coleta dos dados, tinha-se uma grande quantidade de diferentes tipos de registros. No entanto, devido à natureza de nossa questão de pesquisa, utilizamos essencialmente as transcrições das falas dos alunos e professor e, para casos de eventuais dúvidas, os vídeos.

Como o nosso objetivo é compreender as ações do professor promotoras de argumentação, optamos por analisar os dados gerados da implementação de uma das turmas. Para isso selecionamos as aulas 10 e 11 que foram aplicadas conjuntamente (para fins de facilitar a leitura de nossa análise, vamos nos referir as aulas selecionadas sempre como aula 10), que ocasionou uma quantidade de dados rico em diálogos entre professor e aluno uma vez que houve bastante clareza na captação do vídeo e áudio.

$\mathrm{Na}$ aula analisada a investigação realizada almejava dos alunos o entendimento de uma visão quântica sobre o fenômeno dual da luz com base nos resultados experimentais por meio do interferômetro de Mach-Zehnder (IMZ), trabalhado desde a aula 5 da SEI. Em outras palavras, os resultados obtidos pelos alunos por meio do manuseio do aparato experimental, real e virtual, era o ponto de partida para se discutir diferentes interpretações dada pela ciência a fenômenos relacionado a luz. Com isso, seriam apresentadas e discutidas com os alunos as quatro interpretações mais reconhecidas, segundo Pessoa Jr (2003), pela comunidade científica: ondulatória, corpuscular, dualista-realista e da complementaridade (Tabela 4.2). 
Tabela 4.2 - Quatro principais interpretações da Mecânica Quântica sobre o comportamento da luz segundo Pessoa Jr (2003).

\begin{tabular}{cl}
\hline INTERPRETAÇÃO & BREVE EXPLICAÇÃO \\
\hline Ondulatória & A luz se comporta como onda \\
Corpuscular & A luz de comporta como partícula \\
Dualista-Realista & A luz é constituída de uma onda e uma partícula associada a ela \\
Complementaridade & A luz é onda ou partícula, mas nunca ambos ao mesmo tempo \\
\hline
\end{tabular}

Durante a investigação realizada seriam apresentados aspectos positivos e incoerências que cada uma dessas interpretações tem ao explicar os fenômenos observados experimentalmente por meio do IMZ. É valido mencionar que o planejamento discriminado busca, por si só, favorecer o surgimento de situações argumentativas, mas é imprescindivel o desempenho do professor para tornar a abordagem do conteúdo investigativa, permitindo que seus alunos encontrem espaço para exprimirem seus pontos de vista e confrontá-los e justifica-los com outras ideias colocadas em discussão.

\subsection{ALGUNS RESULTADOS PRELIMINARES}

É importante destacar que a aula que selecionamos para análise já foi fonte de dados de outros trabalhos que tinham outros propósitos e objetivos com relação a esse material. A escolha de dados previamente utilizados em outras pesquisas nos permite ter maior clareza sobre diversas nuances que circundam o processo de ensino e aprendizagem em sala de aula, além de proporcionar a construção de conclusões mais fidedignas tanto do ponto de vista teórico como do ponto de vista empírico.

Barrelo Jr (2010) foi o primeiro a fazer a análise desses material e, como mencionado anteriormente, foi com base nos seus propósitos de pesquisa que a SEI foi construída e possibilitou a coleta de diversos registros que compreendemos ser uma rica fonte de dados de pesquisa.

O trabalho de Barrelo Jr (2010), publicado na forma de dissertação de mestrado, possui dois grandes enfoques. O primeiro se refere à questão da inserção de conteúdos da Física Moderna e Contemporânea (FMC) no Ensino Médio por meio da abordagem investigativa. Ambos os pontos desse primeiro enfoque ainda são bastante discutidos por diferentes pesquisadores e educadores, principalmente por não haver uma mudança contínua da prática pedagógica em sala de aula e da estrutura curricular da escola básica. O outro 
enfoque dado no trabalho desse autor se refere à construção de argumentos orais e escritos pelos alunos no contexto mencionado.

Barrelo Jr (2010) inicia sua dissertação apresentando especificidades do ensino de FMC e formas de como torna-lo acessivel aos alunos da escola básica e coerentes com os objetivos da Alfabetização Científica. Unir conteúdos de FMC com as concepções do Ensino por Investigação é uma proposta bastante inovadora, dessa forma, o autor tem grande cuidado ao justificar seus objetivos. Assim, traçado esse panorama inicial, buscou-se compreender a forma como os alunos utilizam e desenvolvem habilidades científicas, como, por exemplo, argumentação e construção de explicações.

Para análise de situações empíricas, oriundas da implementação da Sequência de Ensino Investigativa que havia desenvolvido, o autor usou de distintos instrumentos metodológicos, como, por exemplo, o padrão de argumento de Toulmin (2006), o modelo de raciocínio hipotético-dedutivo de Lawson (2004) e os indicadores de Alfabetização Científica proposto por Sasseron (2008). Esses instrumentos estavam de acordo com o objetivo do autor de identificar eventuais argumentos construídos pelos alunos ao longo da implementação da SEI que havia proposto. Como material de análise, utilizou das transcrições das falas e gestos que ocorreram nas aulas finais da SEI e dos registros escritos dos alunos.

A forma que a análise do material empírico foi realizada permitiu que o autor concluísse que, além de ser possível transpor conceitos de FMC à escola básica por meio de estratégias investigativas, ao estarem inseridos nesse contexto de ensino os alunos são aptos a compreenderam aspectos da natureza da ciência e a construírem argumentos tanto orais quanto escritos.

Em sintese, tendo em vista o nosso objetivo de compreender quais as ações tomadas pelo professor que auxiliam a argumentação dos estudantes, o que gostaríamos destacar é que, ao utilizar os dados de Barrelo Jr (2010), temos a garantia de que argumentos foram construídos pelos alunos nessas aulas.

Machado (2012) foi outro pesquisador que também utilizou dos dados oriundos da pesquisa de Barrelo Jr (2010). A proposta de Machado (2012) era pautada nos objetivos de caracterizar quais são os tipos de perguntas feitas pelo professor em uma aula de Física enquanto os alunos resolvem um problema e quais contribuições que essas perguntas podem trazer a um ensino que vise à Alfabetização Científica. 
Devido ao fato de o material empírico, que também utilizaremos como fonte de dados, ser rico em interações dialógicas entre professor e alunos, Machado (2012) pode encontrar quatro tipos de perguntas feitas pelo professor recorrentes ao longo de uma atividade investigativa: pergunta de problematização; pergunta sobre dados; pergunta exploratória sobre o processo; e pergunta de sistematização (Tabela 4.3).

Tabela 4.3 - Tipos de perguntas feitas pelo professor em uma aula investigativa encontradas por Machado (2012).

\begin{tabular}{|c|c|}
\hline $\begin{array}{c}\text { TIPO DE } \\
\text { PERGUNTA }\end{array}$ & DESCRIÇÃO \\
\hline $\begin{array}{l}\text { Pergunta de } \\
\text { problematização }\end{array}$ & $\begin{array}{l}\text { Remetem-se ao problema estudado ou subjacente a ele dentro da } \\
\text { proposta investigativa. Refazem, reformulam de outra maneira, voltam à } \\
\text { proposta do problema. Ajudam os alunos a planejar e buscar soluções } \\
\text { para um problema e exploram os conhecimentos do aluno antes de eles o } \\
\text { resolverem. Levantam as demandas do problema para que os alunos } \\
\text { iniciem a organização das informações necessárias para resolvê-lo. }\end{array}$ \\
\hline $\begin{array}{l}\text { Pergunta sobre } \\
\text { dados }\end{array}$ & $\begin{array}{l}\text { Abordam os dados envolvidos no problema, seja evidenciando-os, } \\
\text { apresentando-os ou selecionando-os de forma a de descartar ou não } \\
\text { variáveis. Direcionam o olhar do aluno para as variáveis envolvidas } \\
\text { relacionando-as, procurando um grau maior de precisão, comparando } \\
\text { ideias, propondo inversões e mudanças. }\end{array}$ \\
\hline $\begin{array}{l}\text { Pergunta } \\
\text { exploratória sobre } \\
\text { o processo }\end{array}$ & $\begin{array}{l}\text { Buscam que os alunos emitam suas conclusões sobre os fenômenos. } \\
\text { Podem demandar hipóteses, justificativas, explicações, conclusões como } \\
\text { forma de sistematizar seu pensamento na emissão de uma enunciação } \\
\text { própria. Buscam concretizar o aprendizado na situação proposta. Fazem } \\
\text { com que o aluno reveja o processo pelo qual ele resolveu o problema, } \\
\text { elucide seus passos. }\end{array}$ \\
\hline $\begin{array}{l}\text { Pergunta de } \\
\text { sistematização }\end{array}$ & $\begin{array}{l}\text { Buscam que os alunos apliquem o conceito compreendido em outros } \\
\text { contextos, prevejam explicações em situações diferentes da apresentada } \\
\text { pelo problema. Levam o aluno a raciocinar sobre o assunto e a construir o } \\
\text { modelo para explicar o fenômeno estudado. }\end{array}$ \\
\hline
\end{tabular}

Cada pergunta descrita por esse autor apresenta uma especificidade e abrange etapas do processo investigativo que são essenciais ao desenvolvimento da resolução de um problema de investigação e, conforme o descrito pelo próprio autor, “(...) se constituem ontologicamente pela intenção contida na ação enunciativa de perguntar" (p. 46).

Um aspecto importante da proposta de Machado (2012) é que, apesar de os tipos de perguntas apresentadas inicialmente terem sido pensadas para caracterizar as perguntas feitas pelo professor, elas também foram encontradas 
nas falas dos alunos, o que nos permite inferir a importância da participação e colaboração deles no processo de investigação e construção de entendimentos.

Ao final de sua análise, Machado destaca que não há um padrão para o surgimento de cada tipo de pergunta feita pelo professor e que cada pergunta, ao ser proferida, provoca ou solicita dos alunos diferentes tipos de indicadores de Alfabetização Científica, pois contém em sua enunciação uma intenção diferente.

Finalmente, com base nas conclusões apresentadas por Machado (2012), antes de iniciarmos a nossa análise de dados também temos a confirmação de que contamos com um material rico em interações dialógicas entre professor e alunos e que, a depender da forma que essas interações foram desencadeadas, ocasionaram nos alunos o surgimento de destrezas típicas do conhecimento científico, identificadas também com o auxílio dos indicadores de Alfabetização Científica proposto por Sasseron (2008).

\subsection{O PROCESSO DE ANÁLISE}

Para análise dos dados selecionados serão utilizados três conjuntos de categorias visando a contemplar nossos objetivos e a responder nossa questão de pesquisa: (1) indicadores de alfabetização científica (SASSERON, 2008); (2) tipo de perguntas feitas pelo professor (MACHADO, 2012) e; (3) propósitos epistêmicos para promoção da argumentação.

Os indicadores de alfabetização científica, conforme propostos por Sasseron (2008) (tabela 4.4) foram selecionados devido ao fato de já terem sido utilizados nas pesquisas de Barrelo Jr (2010) e Machado (2012) sobre os mesmo dados a serem analisados. Como já mencionado, este conjunto de categorias desvelam destrezas típicas do trabalho e da natureza do conhecimento científico que são utilizadas pelos estudantes durante o intercurso de uma investigação realizada em sala de aula.

É valido retomar que os dez indicadores de alfabetização científica existentes podem ser organizados em subconjuntos que se relacionam com o trabalho com dados empíricos (seriação de informação, organização de informação e classificação de informação), com a obtenção de dados e delimitação de variáveis (levantamento de hipótese e teste de hipótese), com o entrecruzamento de variáveis e informações e construção de conclusões (justificativa, previsão e explicação) e, por fim, com a apropriação das ideias em 
caráter científico e relações entre dados e conclusões (raciocínio lógico e raciocinio proporcional).

Tabela 4.4 - Indicadores de alfabetização científica proposto por Sasseron (2008).

\begin{tabular}{|c|c|}
\hline $\begin{array}{l}\text { INDICADOR } \\
\text { DE AC }\end{array}$ & DESCRIÇÃO \\
\hline Seriação de informação & Pode ser um rol de dados, uma lista de dados trabalhados \\
\hline Organização de Informação & $\begin{array}{l}\text { Define-se pela busca em se mostrar um arranjo para } \\
\text { informações novas ou já elencadas anteriormente }\end{array}$ \\
\hline Classificação de informação & $\begin{array}{l}\text { Constitui-se em um momento de ordenação dos elementos } \\
\text { com os quais se está trabalhando procurando uma relação } \\
\text { entre eles }\end{array}$ \\
\hline Levantamento de hipótese & $\begin{array}{l}\text { Apontam instantes em que são alçadas suposições acerca de } \\
\text { certo tema }\end{array}$ \\
\hline Teste de hipótese & $\begin{array}{l}\text { Concerne em etapas em que são colocadas à prova suposições } \\
\text { anteriormente levantadas }\end{array}$ \\
\hline Justificativa & $\begin{array}{l}\text { Aparece quando em uma afirmação qualquer proferida lança } \\
\text { mão de uma garantia para o que é proposto }\end{array}$ \\
\hline Previsão & $\begin{array}{l}\text { É explicitado quando se afirma uma ação e/ou fenômeno que } \\
\text { sucede associado a certos acontecimentos }\end{array}$ \\
\hline Explicação & $\begin{array}{l}\text { Surge quando se busca relacionar informações e hipóteses já } \\
\text { levantadas }\end{array}$ \\
\hline Raciocínio lógico & $\begin{array}{l}\text { Compreende o modo como às ideias são desenvolvidas e } \\
\text { apresentadas e está relacionada à forma como o pensamento } \\
\text { é exposto }\end{array}$ \\
\hline Raciocínio proporcional & $\begin{array}{l}\text { Refere-se à maneira como variáveis têm relações entre si, } \\
\text { ilustrando a interdependência que pode existir entre elas }\end{array}$ \\
\hline
\end{tabular}

Os tipos de perguntas feitas pelo professor estruturados por Machado (2012) (tabela 4.5), também serão utilizados em nossa análise, pois compreendemos que a traçar um panorama sobre a forma como o professor interage e promove a interação com e entre seus alunos é essencial para que a resposta a nossa questão de pesquisa seja construída. Acreditamos que classificação das perguntas do professor pode nos fornecer um panorama bastante elucidativo sobre todo o processo investigativo que originou nossos dados de análise. Outro ponto que deve ser destacado é que nossos dados também foram analisados e classificados por Machado (2012) de acordo com o conjunto de categorias por ele proposto. Com isso, será possível fazer a comparação de conclusões e, novamente, construção de melhor entendimento sobre o corpus investigado. 
Tabela 4.5 - Tipos de perguntas feitas pelo professor em uma aula investigativa encontradas por Machado (2012).

\begin{tabular}{|c|c|c|}
\hline $\begin{array}{c}\text { TIPO DE } \\
\text { PERGUNTA }\end{array}$ & \multicolumn{2}{|c|}{ DESCRIÇÃO } \\
\hline $\begin{array}{l}\text { Pergunta de } \\
\text { problematização }\end{array}$ & $\begin{array}{l}\text { Remetem-se ao problema estudado } \\
\text { proposta investigativa. Refazem, refor } \\
\text { proposta do problema. }\end{array}$ & $\begin{array}{l}\text { ou subjacente a ele dentro da } \\
\text { rmulam de outra maneira, voltam à }\end{array}$ \\
\hline $\begin{array}{l}\text { Pergunta sobre } \\
\text { dados }\end{array}$ & $\begin{array}{l}\text { Abordam os dados envolvidos no } \\
\text { apresentando-os ou selecionando-os } \\
\text { variáveis. }\end{array}$ & $\begin{array}{l}\text { problema, seja evidenciando-os, } \\
\text { de forma a de descartar ou não }\end{array}$ \\
\hline $\begin{array}{l}\text { Pergunta } \\
\text { exploratória sobre } \\
\text { o processo }\end{array}$ & $\begin{array}{l}\text { Buscam que os alunos emitam suas } \\
\text { Podem demandar hipóteses, justificat } \\
\text { forma de sistematizar seu pensamen } \\
\text { própria. }\end{array}$ & $\begin{array}{l}\text { conclusões sobre os fenômenos. } \\
\text { tivas, explicações, conclusões como } \\
\text { to na emissão de uma enunciação }\end{array}$ \\
\hline $\begin{array}{l}\text { Pergunta de } \\
\text { sistematização }\end{array}$ & $\begin{array}{l}\text { Buscam que os alunos apliquem o c } \\
\text { contextos, prevejam explicações em s } \\
\text { pelo problema. }\end{array}$ & $\begin{array}{l}\text { conceito compreendido em outros } \\
\text { situações diferentes da apresentada }\end{array}$ \\
\hline \multicolumn{3}{|c|}{$\begin{array}{l}\text { O conjunto de categorias que propomos ainda na seção } 3.5 \text { e que } \\
\text { denominamos propósitos epistêmicos para promoção da argumentação (Tabela } \\
\text { 4.6), serão utilizados em decorrência da necessidade de se construir uma visão } \\
\text { sobre o papel do professor em instaurar e conduzir o processo argumentativo em } \\
\text { uma atividade de investigação promovendo a argumentação de seus alunos. }\end{array}$} \\
\hline \multicolumn{3}{|c|}{ Tabela 4.6 - Propósitos epistêmicos para promoção da argumentação. } \\
\hline $\begin{array}{l}\text { PROPÓSITOS } \\
\text { EPISTÊMICOS }\end{array}$ & DESCRIÇÃO & AÇÕES TÍPICAS \\
\hline Retomar & $\begin{array}{l}\text { Levantamento de dados, informações e } \\
\text { situações que já foram trabalhados em } \\
\text { outros momentos. }\end{array}$ & $\begin{array}{l}\text { Retoma informações } \\
\text { Retoma dados } \\
\text { Retoma conceitos }\end{array}$ \\
\hline Problematizar & $\begin{array}{l}\text { Proposições que tornam objeto em } \\
\text { estudo passível de se investigado pelos } \\
\text { alunos. }\end{array}$ & $\begin{array}{l}\text { Propõe um problema } \\
\text { Problematiza uma situação }\end{array}$ \\
\hline Explorar & $\begin{array}{l}\text { Busca a construção de melhor entendi- } \\
\text { mento sobre diferentes hipóteses e } \\
\text { explicações emitidas pelos alunos. }\end{array}$ & $\begin{array}{l}\text { Explora ponto de vista } \\
\text { Explora condições de investigação }\end{array}$ \\
\hline Qualificar & $\begin{array}{l}\text { Ocorre quando o professor classifica e/ou } \\
\text { avalia informações trazidas a discussão } \\
\text { pelos alunos, tais como dados, variáveis, } \\
\text { explicações, etc. }\end{array}$ & $\begin{array}{l}\text { Qualifica variáveis ou fenômenos } \\
\text { Qualifica explicações } \\
\text { Qualifica pontos de vista } \\
\text { Qualifica contexto de investigação }\end{array}$ \\
\hline Sintetizar & $\begin{array}{l}\text { Organização de informações e } \\
\text { explicações trazidas pelos alunos com o } \\
\text { intuito de sistematizar ideias e continuar } \\
\text { ou encerrar o curso da investigação. }\end{array}$ & $\begin{array}{l}\text { Sintetiza informações } \\
\text { Sintetiza explicações }\end{array}$ \\
\hline
\end{tabular}


Concomitante as categorias que serão utilizadas no processo de análise que fizemos, será também utilizado o padrão de argumento de Toulmin (2006) para classificar e organizar os argumentos construídos pelos alunos.

Após a primeira leitura e categorização dos dados, estes foram discutidos e reanalisados conjuntamente com o grupo de pesquisa do LaPEF - Laboratório de Pesquisa em Ensino de Física, o qual fazemos parte, de maneira que aumentássemos o grau de fidedignidade e validade da análise.

Uma vez categorizados todos os turnos de fala transcritos, estes foram separados em trechos e serão apresentados em quadros de forma a facilitar o entendimento do desenvolvimento da aula e de nossas interpretações sobre os dados.

Nas transcrições são demarcados com o sinal gráfico “[ ]” a inclusão de comentários pertinentes, eventuais complementação das falas e descrição de gestos e ambiente que podem comprometer a leitura dos dados caso não sejam discriminados.

Falas que forem citadas ao longo do texto de nossa análise, poderão estar fragmentadas e terem partes suprimidas para aumentar a fluidez da leitura. Os trechos mencionados estarão em itálico e serão demarcados por "aspas". Nestes trechos as sentenças que forem suprimidas serão substituídos pelo sinal gráfico "[...]". 


\section{ANÁLISE DOS DADOS E DISCUSSÃO DOS RESULTADOS}

Apresentaremos nesse capítulo a análise de cunho qualitativo da aula 10 da Sequência de Ensino Investigativa que possibilitou a coleta de nossos dados. Toda a análise feita utilizou como suporte as categorias que denominamos propósitos epistêmicos para promoção da argumentação, bem como os demais referenciais teóricos discriminados nos capítulos anteriores, principalmente os indicadores de alfabetização científica (SASSERON, 2008), os tipos de perguntas feitas pelo professor (MACHADO, 2012) e o Padrão de Argumento de Toulmin (TOULMIN, 2006). Assim, serão descritos trechos da aula selecionada com respectivos comentários de forma a facilitar a compreensão do que ocorreu nesse contexto.

\subsection{Análise da AUla 10}

Pelo objeto de estudo das aulas da SEI (a luz) ser de um elemento físico de características bastante abstratas à percepção dos estudantes, sendo possível apenas a visualização de sua interação com o meio, a dialética envolvida na aula selecionada é necessariamente mediada pelo professor e direcionada ao entendimento dos fenômenos pelos alunos. Desse modo, cria-se um espaço bastante fértil para o surgimento de interações entre professor e alunos na medida em que a investigação planejada se desenvolve.

As aulas precedentes a que selecionamos foram implementadas conforme o planejamento da $\mathrm{SEI}^{7}$, nos garantindo que os alunos tiveram contato com diferentes situações, teorias e conceitos científicos necessários para o entendimento do objeto que seria investigado. Nesses momentos preliminares, os alunos também visitaram o laboratório da escola onde manusearam o Interferômetro de Mach-Zehnder (IMZ) (figura 5.1.a), observaram e analisaram

7 O planejamento da SEI está disponivel na integra no Anexo A. 
diferentes tipos de resultados obtidos por meio desse aparato. Em seguida utilizaram a sala de informática onde, por meio de um software de computador que simulava o IMZ (figura 5.1.b), puderam analisar novas situações e resultados, os quais não foram possiveis de se obter por meio do aparato real, principalmente devido a sua grande sensibilidade e imprecisão.

Em seguida, com dados oriundos dos aparatos real e virtual, com o auxílio do professor, discutiram os procedimentos que foram realizados e alguns conceitos da física clássicos e quânticos relativos ao experimento.
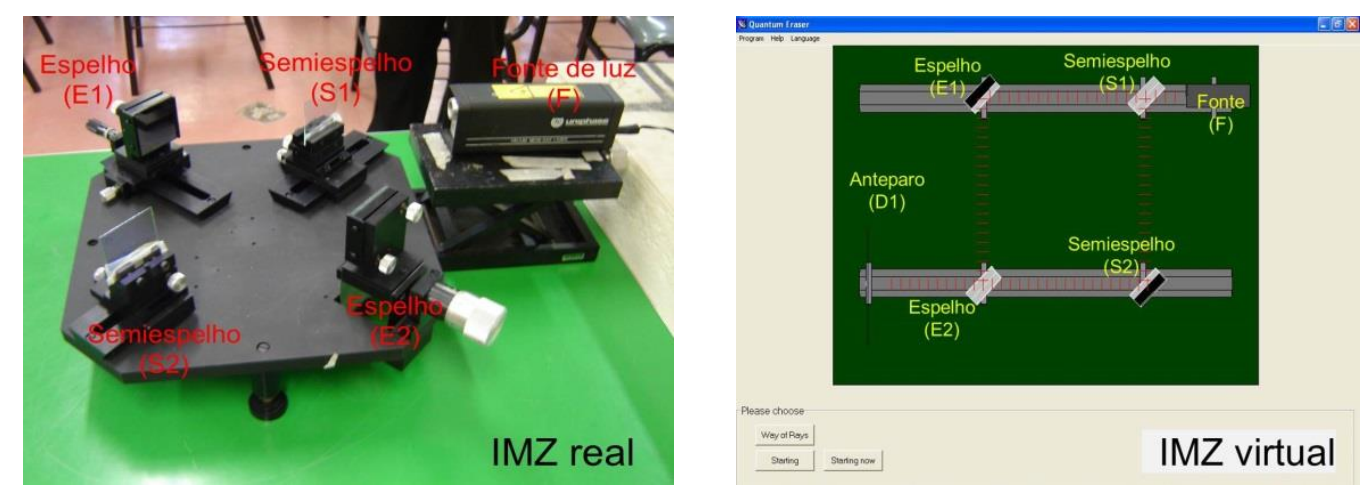

Figura 5.1 - a) Interferômetro de Mach-Zehnder real e b) Imagem do software de simulação do experimento (fonte: BARRELO JR, 2010).

Destacamos novamente que, conforme o planejamento, o objetivo da aula 10 era discutir quatro principais interpretações dadas pela mecânica quântica para o comportamento dual da luz conforme descrito por Pessoa Jr (2003). A discussão foi planejada para ocorrer por meio da análise de situações particulares que geraram diferentes resultados experimentais durante $o$ manuseio do IMZ, tanto real como o virtual.

É válido mencionar que todas as interpretações a serem discutidas ao longo da investigação apresentam algum tipo de incoerência, sendo assim, atribui-se aos dados e informações coletados nas aulas precedentes a que analisaremos um papel essencial no que tange o objetivo de evidenciar características da natureza do conhecimento científico e favorecer a compreensão pelos estudantes sobre o objeto investigado.

A análise apresentada a seguir será subdividida em seis episódios organizados conforme os objetivos de cada momento da aula. As falas do professor e dos alunos serão dispostas em trechos compostos por turnos de fala 
(termo que está abreviado ao longo do texto com a letra "T") e numeradas de acordo com a ordem que surgiram na transcrição integral da aula8.

Neste ponto é importante mencionar que a transcrição integral da aula é composta por 307 turnos de fala, pois, como destacamos no capitulo anterior, a atividade de investigação que permitiu a nossa coleta de dados foi implementada ao longo de duas aulas que ocorreram conjuntamente, tornando-a razoavelmente longa.

De forma a explicitar as interpretações sobre os dados à luz das categorias de análise selecionadas e previamente discutidas, organizamos quadros que dispõem colunas com as seguintes informações: numeração dos turnos de falas em ordem cronológica, falas dos sujeitos, propósitos epistêmicos, os tipos de perguntas que foram feitas pelo professor e os indicadores de alfabetização científica encontrados nas falas dos alunos. Outro ponto a ser ressaltado é que a categorização dos turnos segundo os tipos de perguntas e segundo os indicadores de alfabetização científica foram feitas, respectivamente, por Machado (2012) e Barrelo Jr (2010).

\subsubsection{EPISÓDIO 1 - RETOMANDO INFORMAÇÕES}

A aula tem início com o professor fazendo basicamente um trabalho de organização e gerenciamento da turma. Os alunos estão dispostos em círculo e após a divulgação de alguns comunicados a discussão é iniciada apresentandose algumas das diretrizes e expectativas da aula e retomando características do IMZ. O professor utiliza uma apresentação Power Point ${ }^{\circledR}$ como recurso instrucional e os alunos possuem em mãos uma lauda referente à atividade de sistematização $^{9}$ dos conteúdos a serem abordados que, por sua vez, será preenchida individualmente apenas ao final da investigação.

Já nesse primeiro momento são apresentadas aos alunos quais são as quatro interpretações sobre a natureza da luz a serem discutidas: ondulatória, corpuscular, complementaridade e dualista-realista. A partir disso, o professor promove interações e debates com o intuito de caracterizar cada uma delas, ou seja, inicia a investigação propriamente dita.

8 No anexo C está disponível a transcrição integral da aula com as respectivas categorias de análise associadas a cada turno de fala do professor e alunos.

${ }^{9}$ A atividade de sistematização está disponivel no Anexo B. 
A opção do professor em apresentar as interpretações nesse momento coloca em evidência que seu objetivo é tornar mais claro o entendimento sobre cada uma das interpretações e não reconstruí-las com os alunos. Nesse sentido, busca-se retomar e colocar destaque conceitos e elementos teóricos, bem como variáveis e características distintas relacionadas à natureza da luz. Sendo mais específico, busca-se colocar em discussão aspectos ligados às teorias ondulatória clássica e quântica e aos comportamentos ondulatórios e corpusculares que a luz presentou quando trabalharam com o IMZ.

Com base no planejamento da aula e nos conhecimentos e conteúdos já trabalhados com os alunos, foi possivel organizar, segundo o modelo de Toulmin, um argumento que explicita os elementos a serem retomados (figura 5.2). É valido destacar que este é um argumento de referência e não se espera que ele seja verbalizado da forma como foi construído. Outro aspecto importante a ser destacado é que, provavelmente, o argumento já foi construído, de forma completa ou parcial, pelos alunos em outras investigações que ocorreram nas aulas anteriores, e que por isso exprime informações a serem trabalhadas durante a retomada. Em outras palavras, o argumento que elaboramos discrimina os dados e conceitos que o professor almeja evidenciar para que, então, possa ter garantia que os alunos tenham consciência das informações necessárias para a construção de entendimento sobre o objeto investigado na aula em análise.

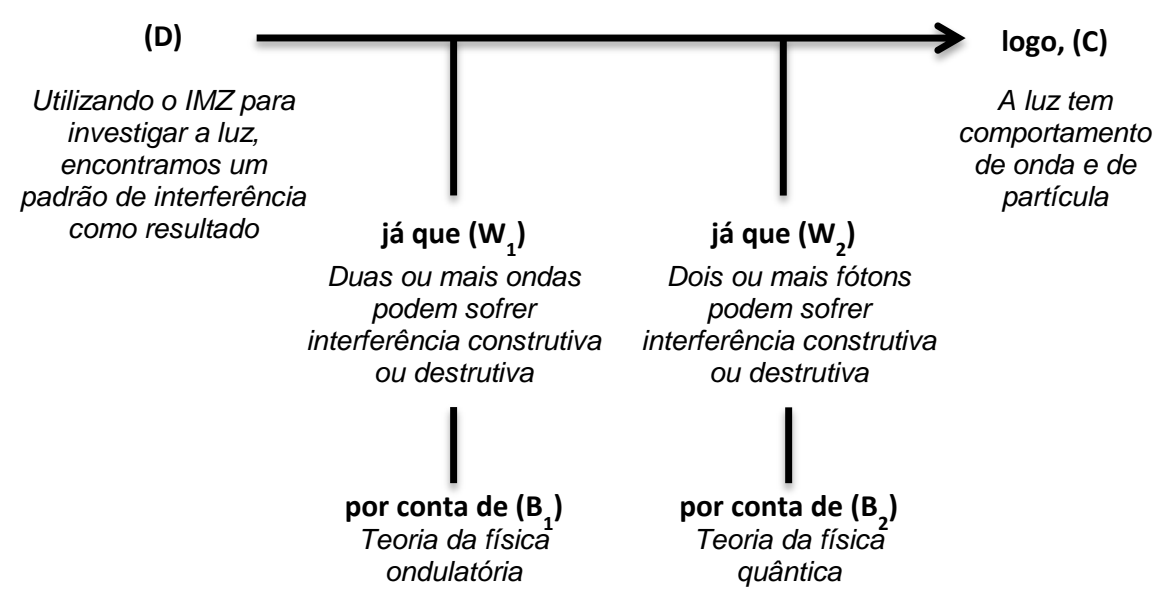

Figura 5.2 - Argumento feito com base na análise do planejamento da SEI que explicita informações a serem retomadas pelo professor. 
O processo de retomada é essencial para que seja possivel resgatar dados e conceitos trabalhados anteriormente, essenciais à investigação que está a se iniciar, por isso o professor tem grande cuidado em apresenta-los aos alunos e coloca-los em discussão. Com este objetivo, ele reapresenta aos alunos as imagens do IMZ (figura 5.1.a; figura 5.1.b) e dos padrões de interferência, os resultados típicos obtidos pelo experimento (figura 5.3).

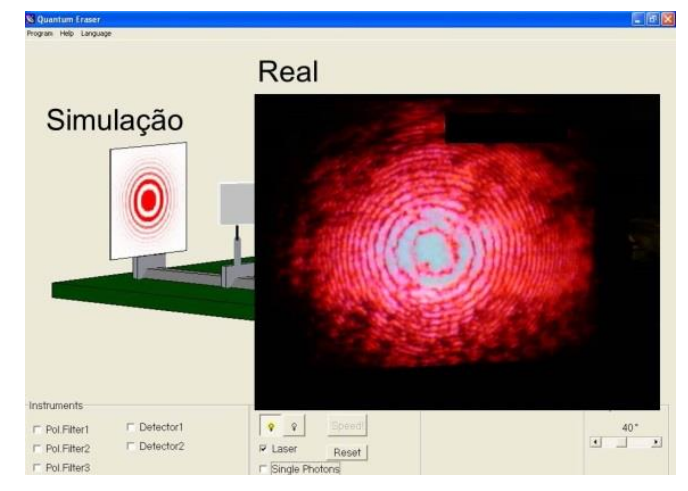

Figura 5.3 - Imagens de resultados típicos obtidos por meio do IMZ real e virtual.

Com o intuito de estimular a participação dos alunos na discussão, o professor busca retomar os dados por meio de questões direcionadas à turma. Desse modo a discussão é encaminhada e mediada.

\begin{tabular}{|c|c|c|c|c|}
\hline $\mathbf{T}$ & Falas Transcritas & $\begin{array}{l}\text { Propósitos } \\
\text { Epistêmicos }\end{array}$ & $\begin{array}{l}\text { Tipo de } \\
\text { Pergunta }\end{array}$ & $\begin{array}{l}\text { Indicadores } \\
\text { de AC }\end{array}$ \\
\hline 02 & $\begin{array}{l}\text { Professor: [...] Bom, aí eu separei então duas } \\
\text { imagens, uma do interferômetro real e a outra } \\
\text { do simulador [aponta para a imagem projetada, } \\
\text { ver fig. 5.3], certo? Foi isso que a gente } \\
\text { observou, certo? Foi isso que você viu, Bia? }\end{array}$ & Retomar & $\begin{array}{l}\text { Pergunta sobre } \\
\text { dados }\end{array}$ & \\
\hline 03 & Beatriz: Não. & & & \\
\hline 04 & $\begin{array}{l}\text { Professor: Alguém enxergou uma figura } \\
\text { parecida com essa do real? }\end{array}$ & Retomar & $\begin{array}{l}\text { Pergunta sobre } \\
\text { dados }\end{array}$ & \\
\hline 05 & Priscila: Não. & & & \\
\hline 06 & Professor: Ninguém? & Retomar & & \\
\hline 07 & Alunos: Não. & & & \\
\hline 08 & $\begin{array}{l}\text { Professor: Nem naquela outra experiência que } \\
\text { a gente usou só um laser e um tecido como } \\
\text { rede de difração? }\end{array}$ & Retomar & $\begin{array}{l}\text { Pergunta sobre } \\
\text { dados }\end{array}$ & \\
\hline 09 & Aline: Sim. Eu. & & & \\
\hline 10 & $\begin{array}{l}\text { Professor: Que a gente projetou lá na parede } \\
\text { ou no quadro? }\end{array}$ & Retomar & & \\
\hline 11 & $\begin{array}{l}\text { André: Era assim, desse jeito. [mostra a mão } \\
\text { indicando forma de círculos de diferentes } \\
\text { tamanhos com os dedos, indicador e polegar } \\
\text { direito] }\end{array}$ & & & $\begin{array}{l}\text { Seriação de } \\
\text { informações }\end{array}$ \\
\hline
\end{tabular}


Com relação às perguntas sobre dados proferidas nos turnos 02 e 04, mesmo com alguns alunos tendo respondido negativamente a elas (T03, T05 e T07) o professor insiste na busca pela participação da turma nesse momento inicial, recolocando a questão de maneiras distintas, como, por exemplo, perguntando: "Nem naquela outra experiência [...]?". Nesse ponto, vemos que a busca pela retomada ocorre por meio da explicitação de outra situação em que a experiência realizada não havia sido bem sucedida. Ou seja, recorre-se a uma ocasião específica, mas que, provavelmente, tivera bastante destaque para os alunos, pois começam a surgir as primeiras contribuições à investigação.

Outra possibilidade que poderia ter ocorrido no desenvolvimento de uma investigação em sala de aula, seria o professor acatar a resposta negativa dada pela aluna Beatriz (T03) ou pela aluna Priscila (T05) e expor as informações a serem retomadas. No entanto essa prática tenderia a inibir a participação dos demais alunos e, por consequência, a contribuição do aluno André (T11 e T13), que dá início a seriação e organização de informações, não seria exposta.

\begin{tabular}{|c|c|c|c|c|}
\hline \multicolumn{5}{|c|}{ Quadro 2 - Trecho de falas da aula } \\
\hline $\mathbf{T}$ & Falas Transcritas & $\begin{array}{l}\text { Propósitos } \\
\text { Epistêmicos }\end{array}$ & $\begin{array}{l}\text { Tipo de } \\
\text { Pergunta }\end{array}$ & $\begin{array}{l}\text { Indicadores } \\
\text { de AC }\end{array}$ \\
\hline 13 & $\begin{array}{l}\text { André: Era tipo... Um monte. Um monte não, } \\
\text { não sei... }\end{array}$ & & & $\begin{array}{l}\text { Organização de } \\
\text { informações }\end{array}$ \\
\hline 14 & Professor: Uma do lado da outra, não é isso? & Qualificar & & \\
\hline 15 & André: $\hat{E}$. & & & \\
\hline 16 & $\begin{array}{l}\text { Professor: É que eu tirei a foto daqui agora, ta } \\
\text { no outro computador. A outra possibilidade, } \\
\text { tinha uma outra foto, ao invés da gente } \\
\text { enxergar dessa forma, a gente enxergava mais } \\
\text { ou menos isso aqui [aponta para uma imagem } \\
\text { semelhante ao resultado obtido pela simulação, } \\
\text { fig. 5.3], como disse o André. Também a gente } \\
\text { tinha essa observação... Bom, aí lá na nossa } \\
\text { experiência, pedi pra que vocês identificassem. } \\
\text { Era essa identificação que a gente tinha. E foi } \\
\text { pedido pra vocês desenharem aí como é que } \\
\text { era o caminho que tava sendo percorrido pela } \\
\text { luz [dentro do IMZ]. E aí a simulação mostrava } \\
\text { pra vocês como duas frentes de onda, certo? } \\
\text { Aí a pergunta feita, não tá no textinho, não tá } \\
\text { no roteiro, a gente colocou um anteparo aqui } \\
\text { [aponta para um ponto entre o espelho E1 e o } \\
\text { semiespelho S2, fig. 5.1], certo? Se a gente } \\
\text { colocasse o anteparo aqui, deste outro lado } \\
\text { [aponta para um ponto entre o espelho E2 e o } \\
\text { semiespelho S2, fig. 5.1], o que a gente deveria } \\
\text { ver? Qual a relação com essas duas figuras? }\end{array}$ & $\begin{array}{l}\text { Sintetizar } \\
\text { Retomar }\end{array}$ & $\begin{array}{l}\text { Pergunta sobre } \\
\text { dados }\end{array}$ & \\
\hline 17 & Bruna: Complementar & & & $\begin{array}{l}\text { Classificação } \\
\text { de informações }\end{array}$ \\
\hline 18 & Professor: Como assim? & Explorar & & \\
\hline 19 & $\begin{array}{l}\text { Bruna: Por exemplo, seria assim, numa o } \\
\text { centro seria claro e teria as listras e na outra é } \\
\text { ao contrário, o centro preto e as listras ao } \\
\text { contrário. }\end{array}$ & & & $\begin{array}{l}\text { Levantamento } \\
\text { de hipóteses }\end{array}$ \\
\hline
\end{tabular}


Prosseguindo com a investigação, o professor continua o processo de retomada (T16), mas adiciona elementos que foram discutidos durante a investigação do IMZ que ocorreu nas aulas anteriores, sistematizando algumas das ideias e problematizando uma situação específica colocando em discussão um problema que foi solucionado nesse outro momento. Ao perguntar aos alunos: "se a gente colocasse um anteparo aqui [...] o que a gente deveria ver? Qual a relação com essas duas figuras?” (T16), abre-se precedente para se aprofundar nas informações sobre o experimento e os resultados que já tinham sido obtidos. Notemos que apesar de termos encontrados na fala do professor os propósitos epistêmicos problematizar, o tipo de pergunta que está sendo posta aos alunos é do tipo pergunta sobre dados e os indicadores de alfabetização científica encontrados são referentes ao trabalho com dados empíricos, deixando assim evidente o objetivo de se atingir o propósito de retomar informações.

Ainda lançando perguntas aos alunos, o professor prossegue a investigação, dando espaço para que outros alunos participem emitindo suas respostas.

\begin{tabular}{|c|c|c|c|c|}
\hline \multicolumn{5}{|c|}{ Quadro 3 - Trecho de falas da aula } \\
\hline $\mathbf{T}$ & Falas Transcritas & $\begin{array}{l}\text { Propósitos } \\
\text { Epistêmicos }\end{array}$ & $\begin{array}{l}\text { Tipo de } \\
\text { Pergunta }\end{array}$ & $\begin{array}{l}\text { Indicadores } \\
\text { de AC }\end{array}$ \\
\hline 20 & $\begin{array}{l}\text { Professor: Como que é, Vitor? Fala alto pra } \\
\text { classe ouvir. }\end{array}$ & & & \\
\hline 21 & $\begin{array}{l}\text { Vitor: Se a gente colocasse o anteparo aqui } \\
\text { [aponta para um ponto entre o espelho E2 e o } \\
\text { semiespelho S2, ver fig. 5.1] e não aqui [aponta } \\
\text { para um ponto entre o espelho E1 e o } \\
\text { semiespelho S2, ver fig. 5.1], seria o inverso do } \\
\text { que a gente viu. }\end{array}$ & & & $\begin{array}{l}\text { Levantamento } \\
\text { de hipóteses }\end{array}$ \\
\hline 22 & Alunos: [Inaudível] & & & \\
\hline 23 & Vitor: Seria o inverso do que a gente viu. & & & \\
\hline 24 & $\begin{array}{l}\text { Professor: Todo mundo acha que é isso? Todo } \\
\text { mundo acha que é a mesma coisa? E alguém } \\
\text { sabe explicar por quê? Então olha, vamos } \\
\text { imaginar... O que vocês tão me dizendo é isso, } \\
\text { num anteparo a gente observa alguma coisa } \\
\text { parecida com isso [mostra uma imagem } \\
\text { semelhante a interferência da fig. 5.3], certo? } \\
\text { No outro, a gente vai enxergar o contrário, não } \\
\text { é isso? Elas seriam complementares porque se } \\
\text { a gente juntasse as figuras, veria o quê? }\end{array}$ & $\begin{array}{l}\text { Explorar } \\
\text { Sintetizar } \\
\text { Explorar }\end{array}$ & $\begin{array}{l}\text { Pergunta sobre } \\
\text { dados }\end{array}$ & \\
\hline
\end{tabular}

Nos turnos 21 e 23, o aluno Vitor traz mais informações sobre o experimento o que começa a clarificar as informações que estão sendo resgatadas. É interessante observar que as falas de Vitor se sobrepõem as de Bruna (T19), sendo quase equivalentes, mesmo assim o professor permite que 
eles exponham suas ideias, motivando-os a participarem do processo investigativo.

Emitida as contribuições de Bruna e Vitor, no turno 24 vemos que o professor dá continuidade à discussão sintetizando e explorando as informações que foram trazidas por ambos: "[...] O que vocês tão me dizendo é isso, num anteparo a gente observa alguma coisa parecida com isso [mostra uma imagem semelhante a da fig. 5.3, certo? No outro, a gente vai enxergar ao contrário, não é isso? [...]". Dessa forma, explicitam-se algumas características do experimento e permite ao professor explorar ainda mais a situação por meio da solicitação da análise a resposta de fornecida por Bruna e colocando na forma de pergunta aos alunos: "[...] Elas seriam complementares porque se a gente juntasse as figuras, veria o quê?".

\begin{tabular}{|c|c|c|c|c|}
\hline$\frac{\mathrm{Qu}}{\mathrm{T}}$ & $\begin{array}{l}\text { de falas da aula } \\
\text { Falas Transcritas }\end{array}$ & $\begin{array}{l}\text { Propósitos } \\
\text { Epistêmicos }\end{array}$ & $\begin{array}{l}\text { Tipo de } \\
\text { Pergunta }\end{array}$ & $\begin{array}{l}\text { Indicadores } \\
\text { de AC }\end{array}$ \\
\hline 29 & $\begin{array}{l}\text { Lucas: [quase inaudível, tentando explicar o } \\
\text { que está acontecendo] É igual aquela } \\
\text { experiência que a gente batia o dedo na água e } \\
\text { fazia umas ondas, elas se aumentavam, } \\
\text { aumentava não, elas ficavam juntas [entrelaça } \\
\text { os dedos das mãos] só que eu esqueci o nome } \\
\text { do fenômeno. }\end{array}$ & & & Justificativa \\
\hline 30 & Professor: Interferência de ondas? & Explorar & & \\
\hline 31 & $\begin{array}{l}\text { Lucas: É, acho que é. Só que faz mile e anos, } \\
\text { tá ligado. }\end{array}$ & & & $\begin{array}{l}\text { Levantamento } \\
\text { de hipótese }\end{array}$ \\
\hline 32 & $\begin{array}{l}\text { Professor: Pessoal, a gente tá dizendo aqui } \\
\text { oh... A gente tá observando nesse ponto } \\
\text { [aponta para o a imagem obtida como } \\
\text { resultado pelo IMZ, fig. 5.3] a interferência das } \\
\text { ondas, certo? E a gente enxerga aqueles } \\
\text { pontos coloridos quando a interferência é } \\
\text { construtiva. O que significa isso? As duas } \\
\text { frentes de onda que estão se encontrando, } \\
\text { estão na mesma fase, então elas se somam e } \\
\text { você vê o ponto claro. Quando elas estão em } \\
\text { fases opostas, a gente vê o que? A } \\
\text { interferência é destrutiva, elas se anulam, não } \\
\text { é isso? O que acontece desse ponto pra esse é } \\
\text { uma inversão dessas fases, tá? }\end{array}$ & $\begin{array}{l}\text { Retomar } \\
\text { Sintetizar } \\
\text { Qualificar }\end{array}$ & & \\
\hline
\end{tabular}

No turno seguinte, o aluno Lucas (T29) abre precedentes para que se explorasse a ideia de interferências de ondas (T30), conceito apresentado em sua fala enquanto tentava explicar a questão colocada pelo professor ainda no turno 24. Complementando a contribuição de Lucas, o professor inicia sua fala sintetizando o que havia sido ressaltado, qualificando, consequentemente, a resposta de Lucas como adequada para aquela situação e, finalmente, retomando informações o IMZ e conceitos relacionados aos resultados por ele obtidos. 
Iniciada a aula e colocadas as primeiras questões, as informações que foram levantadas, fornecidas principalmente pelos alunos, começam configurar variáveis e aportes para o desenvolvimento da investigação. Esse processo foi possivel porque o professor retomou diferentes aspectos do IMZ enquanto solicitava a participação dos alunos por meio, principalmente, de perguntas sobre dados. Além disso, resgatando o argumento da figura 5.2, que discrimina os aportes necessários para compreensão do problema da aula, podemos inferir que as questões colocadas aos alunos nos turnos 16, 24 e 30, além de serem caracterizadas como ações ligadas aos propósitos epistêmicos problematizar e explorar, marcam o início da organização das garantias $\left(\mathrm{W}_{1}\right.$ - duas ou mais ondas podem sofrer interferência construtiva ou destrutiva) e de seu apoio ( $\mathrm{B}_{1}$ conceitos da teoria ondulatória), pois, como vemos, as repostas dos alunos Beatriz (T17 e T19) e Vitor (T21 e T23) às questões feitas pelo professor descrevem o objeto investigado com clareza, explicitando informações.

\subsection{1.a. Sintese do episódio 1}

Conforme descrito no mapa do episódio (Tabela 5.1), neste primeiro episódio, que compreende dos turnos de fala 1 ao 32, todos os propósitos epistêmicos estiveram presentes nas fala do professor. Os propósitos retomar e qualificar foram os mais frequentes, sete e cinco ocorrências, respectivamente.

O número absoluto de ocorrência de cada uma das categorias não é suficiente para se tecer conclusões sobre o processo argumentativo que estava sendo iniciado. Todavia, com base na leitura da análise detalhada na seção anterior, é possivel perceber que nesse momento o professor buscou resgatar essencialmente informações necessárias para que a investigação se iniciasse, tais como, características do aparato experimental e alguns dos seus resultados, o que tornou o propósito epistêmico retomar bastante frequente, com sete ocorrências, nos trechos discriminados na seção anterior.

A retomada ocorreu essencialmente por meio da descrição de características do IMZ feita pelo professor enquanto formulava perguntas sobre dados aos alunos que, ao emitirem suas respostas, explicitavam informações importantes para o processo investigativo. Tendo conhecimento das respostas 
Quadro 5 - Mapa do episódio 1: classificação dos turnos de fala de alunos e professor segundo as categorias metodológicas selecionadas.

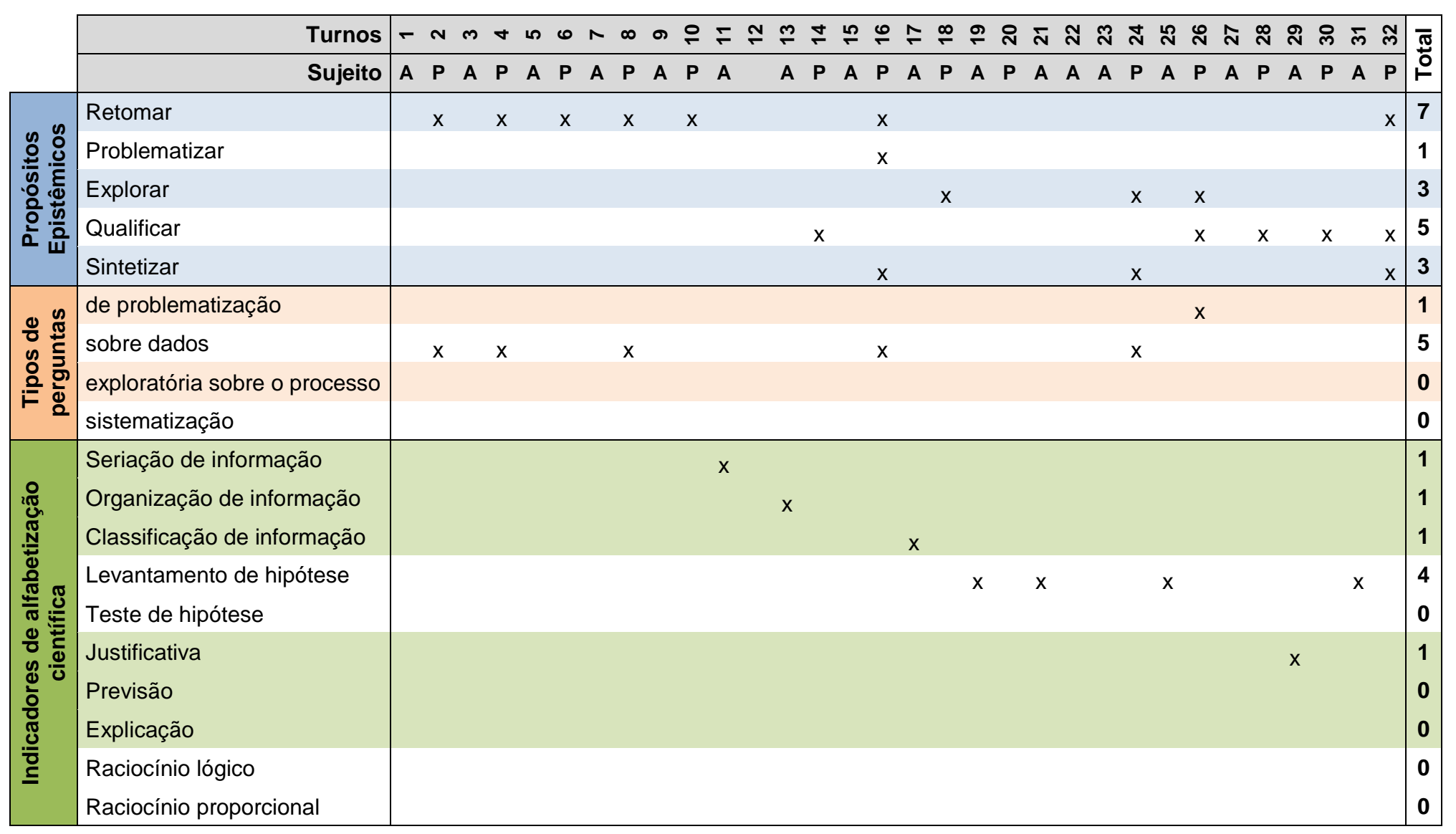


dos alunos, o professor qualificava essas contribuições de forma a construir os aportes necessários para o desenvolvimento da investigação.

Os indicadores de alfabetização científica mais recorrentes nesse episódio foram os que estão relacionados com o trabalho com dados empíricos (seriação, organização e classificação de informação), que totalizaram três ocorrências, e com a obtenção dos dados e delimitação de variáveis (levantamento de hipótese), com 4 ocorrências, o que corrobora com a ideia de que o professor almejava retomar dados e informações para engajamento dos alunos no processo argumentativo e investigativo.

\subsubsection{EPISÓDIO 2 - EXPLORANDO SITUAÇÕES}

Uma vez retomadas características do IMZ e alguns dos seus resultados, o professor dá início à exploração de outras situações relacionadas ao experimento.

\begin{tabular}{|c|c|c|c|c|}
\hline \multicolumn{5}{|c|}{ Quadro 6 - Trecho de falas da aula } \\
\hline $\mathbf{T}$ & Falas Transcritas & $\begin{array}{l}\text { Propósitos } \\
\text { Epistêmicos }\end{array}$ & $\begin{array}{l}\text { Tipo de } \\
\text { Pergunta }\end{array}$ & $\begin{array}{c}\text { Indicadores } \\
\text { de AC }\end{array}$ \\
\hline 38 & $\begin{array}{l}\text { Professor: Isso. E aí o que vai tá acontecendo? } \\
\text { Vamos supor que a fase } 1 \text { tá vindo pra cá e a } 2 \\
\text { pra cá, certo? Nesse caso aqui, eu vou pegar a } \\
1 \text { deste, né? E vai interferir com a outra que tá } \\
\text { aqui, não é isso? Então o que tá acontecendo é } \\
\text { que ela tá pegando os lados simétricos, tudo } \\
\text { bem? Bom, aí a gente mudou pra fóton. Como } \\
\text { vocês bem responderam na última aula, o que } \\
\text { acontece com o padrão da figura? O resultado. }\end{array}$ & $\begin{array}{l}\text { Sintetizar } \\
\text { Retomar }\end{array}$ & $\begin{array}{l}\text { Pergunta sobre } \\
\text { dados }\end{array}$ & \\
\hline 39 & Lucas: Igual, mas pontinhos. & & & $\begin{array}{l}\text { Classificação } \\
\text { de informações }\end{array}$ \\
\hline 40 & $\begin{array}{l}\text { Professor: É o mesmo, não é? O que ta } \\
\text { acontecendo só é que a gente aqui vai... } \\
\text { Quando a gente manda com o laser forma } \\
\text { imagem instantaneamente, não é isso? Todo o } \\
\text { fóton... Ele vai se distribuindo, né? E } \\
\text { dependendo da quantidade que a gente tem aí } \\
\text { a gente vai acabar observando a linha, certo? } \\
\text { Até aqui nenhuma novidade, né? Tudo bem aí, } \\
\text { Guilherme? Explica essas duas figuras aí pra } \\
\text { mim, por favor [aponta para as imagens da } \\
\text { fig.5.4]. Fala aí, Daniel. }\end{array}$ & Explorar & & \\
\hline
\end{tabular}

Como vimos no final do episódio anterior, após o turno 32, uma aluna refraseia a fala do professor com o intuito de verificar seu próprio entendimento sobre os conceitos de interferência construtiva e destrutiva. Em seguida, no turno 38, o professor sintetiza novamente a mesma informação e continua com o processo de retomada, modificando as variáveis da situação anterior e 
problematizando-a com a questão: "Bom, aí a gente mudou para fóton. Com vocês bem responderam na última aula, o que acontece com o padrão da figura?”.

A pergunta feita pelo professor, categorizada como uma pergunta sobre dados, continua a evidenciar seu objetivo de retomar informações sobre o IMZ. Ou seja, nesse momento almeja-se a explicitação de variáveis e conceitos relacionados à ideia de luz corpuscular, que correspondem à garantia $\mathrm{W}_{2}$ e ao apoio $\mathrm{B}_{2}$, conforme apresentado no argumento da figura 5.2. Essas informações haviam sido debatidas conjuntamente durante a discussão sobre o comportamento ondulatório da luz, por essa razão possuem explicações análogas. Diante disso, a breve resposta dada pelo aluno Lucas (T39) foi suficiente para que o professor retomasse e sintetizasse outras características relacionadas aos resultados do experimento. No entanto, retomado os resultados, ao final do turno 40, vemos que se inicia um processo de exploração da situação de investigação com o professor solicitando a explicação dos resultados aos alunos (T40).

Na continuidade da discussão o professor repõe as imagens com os dois resultados obtidos pelo IMZ (figura 5.4) e inicia novas perguntas aos alunos.
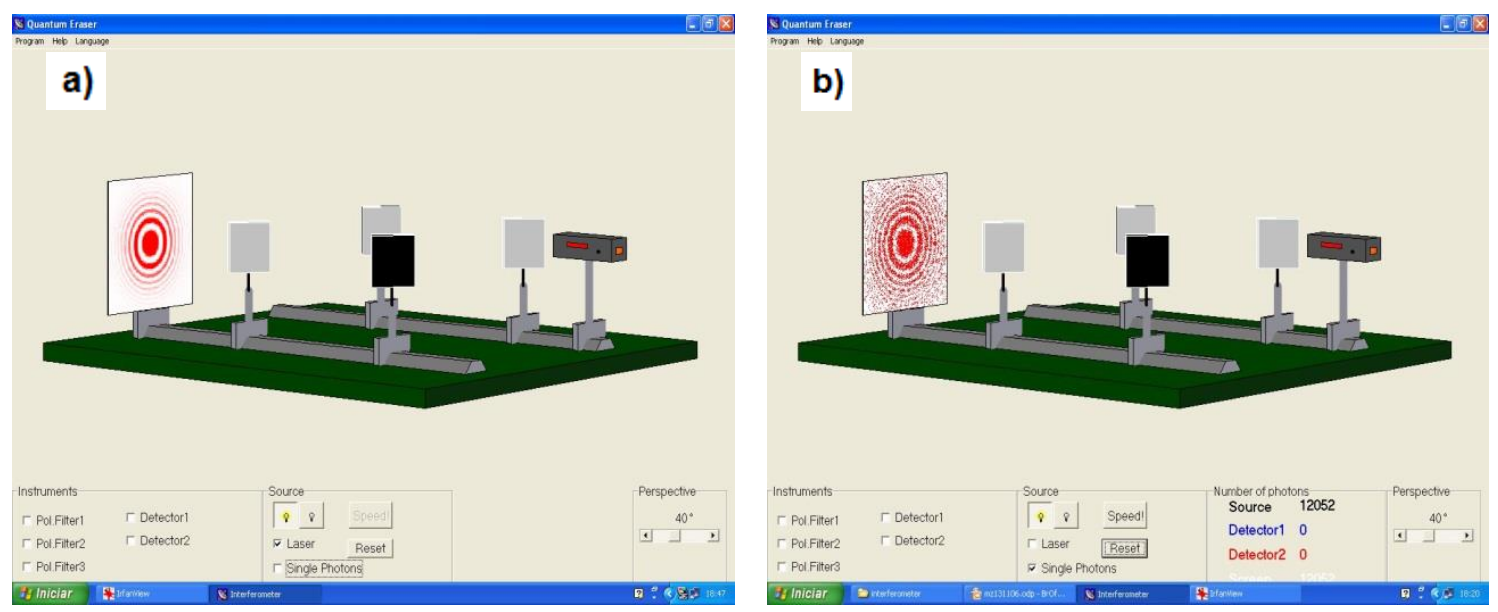

Figura 5.4 - Imagens utilizadas pelo professor para discutir resultados obtidos pelo IMZ considerando diferentes variáveis. Resultado obtido para a) luz enquanto ondas e b) como partícula.

Notemos que os resultados expressos nas figuras são bastante semelhantes, mas obtidos por meio de configurações experimentais diferentes. No primeiro caso (fig. 5.4.a) o padrão de interferência é formado por ondas, enquanto que no segundo (fig. 5.4.b) o padrão foi formado por partículas, ou 
conforme nomeado na discussão, fótons. Dessa maneira, o professor busca então explorar as ideias análogas relacionadas as duas situações colocadas em discussão.

\begin{tabular}{|c|c|c|c|c|}
\hline \multicolumn{5}{|c|}{ Quadro 7-Trecho de falas da aula } \\
\hline $\mathbf{T}$ & Falas Transcritas & $\begin{array}{l}\text { Propósitos } \\
\text { Epistêmicos }\end{array}$ & $\begin{array}{l}\text { Tipo de } \\
\text { Pergunta }\end{array}$ & $\begin{array}{l}\text { Indicadores } \\
\text { de AC }\end{array}$ \\
\hline 47 & Professor: O que eles têm de semelhante? & Explorar & $\begin{array}{l}\text { Pergunta sobre } \\
\text { dados }\end{array}$ & \\
\hline 48 & Daniel: O desenho... & & & $\begin{array}{l}\text { Organização de } \\
\text { informações }\end{array}$ \\
\hline 49 & $\begin{array}{l}\text { Professor: A imagem? Tá, e o que vai ter de } \\
\text { diferente? }\end{array}$ & Explorar & $\begin{array}{l}\text { Pergunta sobre } \\
\text { dados }\end{array}$ & \\
\hline 50 & Daniel: É como se forma. & & & $\begin{array}{l}\text { Classificação } \\
\text { de informações }\end{array}$ \\
\hline 51 & Professor: É o que? & Explorar & & \\
\hline 52 & $\begin{array}{l}\text { Lucas: Gradativamente, professor, conforme os } \\
\text { fótons vão chegando. }\end{array}$ & & & $\begin{array}{l}\text { Classificação } \\
\text { de informações }\end{array}$ \\
\hline 53 & $\begin{array}{l}\text { Professor: Dessa maneira [aponta para a } \\
\text { imagem da fig } 5.4 \text { - a], a formação, ela é } \\
\text { instantânea, né? E nessa aqui, [aponta apara } \\
\text { imagem da fig } 5.4-\text { b] ele vai se formando } \\
\text { conforme vai acontecendo a chegada das } \\
\text { partículas. }\end{array}$ & $\begin{array}{l}\text { Qualificar } \\
\text { Sintetizar }\end{array}$ & & \\
\hline
\end{tabular}

Proposto aos alunos que comparassem os resultados das imagens acima, o professor continua a explorar características do IMZ por meio de perguntas sobre dados direcionadas aos alunos as diferenças e semelhanças entre os resultados obtidos quando se trabalhava com ondas e quando se trabalhava com fótons (T47 e T49).

No turno 53, vemos que o professor qualifica a resposta do aluno Lucas (T50) e sintetiza as informações que foram trazidas a discussão naquele instante. Nas palavras do próprio professor, as diferenças entre as imagens é que em uma “(..) a formação, ela é instantânea, né? E nessa aqui, ele vai se formando conforme vai acontecendo a chegada das partículas” (T53). Essa fala representa um ponto importante ao processo de investigação, pois qualifica e correlaciona as variáveis que estão sendo analisadas, sintetiza a ideia que pode ser reescrita da seguinte maneira: "quando estamos trabalhando com ondas, o padrão de interferência se forma instantaneamente, enquanto que na outra imagem o padrão de interferência se forma conforme as partículas vão atingindo o anteparo que imprime a figura".

É importante destacar que os dados (D) e conclusões (C) do argumento da figura 5.2 já estão claro aos alunos, pois a discussão está ocorrendo em torno dessas informações, ou seja, o que se almeja é evidenciar as garantias ( $\mathrm{W}_{1}$ e $\mathrm{W}_{2}$ ) e apoios $\left(B_{1}\right.$ e $\left.B_{2}\right)$ que autorizam a ligação entre esses elementos. Além disso, até 
esse instante, foram retomados diversos dados e informações necessários ao desenvolvimento da investigação. Todas elas estão relacionadas a alguma das interpretações dada pela mecânica quântica ao comportamento dual da luz, mas as mesmas ainda não estão claras e deverão ser mais bem exploradas ao longo da aula. De qualquer forma, a partir desse momento podemos afirmar que os alunos tem conhecimento de que, por um lado, a luz é uma onda e o IMZ revela instantaneamente como resultado a imagem de um padrão de interferência construtiva e destrutiva; por outro lado, a luz também pode é partícula (fóton) e, apesar de também sofrerem interferência, esse resultado é obtido gradativamente, diferentemente da situação anterior.

Como já mencionado, a ideia de luz como onda ou como partícula é essencial para o prosseguimento da investigação em desenvolvimento. No entanto, compreender esses aspectos relacionados ao objeto de investigação não é trivial. Assim, essa dúvida pode ser encontrada em diferentes momentos e falas dos alunos que, frequentemente questionam variáveis e outros elementos que compõem a investigação.

\begin{tabular}{|c|c|c|c|c|}
\hline \multicolumn{5}{|c|}{ Quadro 8 - Trecho de falas da aula } \\
\hline $\mathbf{T}$ & Falas Transcritas & $\begin{array}{l}\text { Propósitos } \\
\text { Epistêmicos }\end{array}$ & $\begin{array}{l}\text { Tipo de } \\
\text { Pergunta }\end{array}$ & $\begin{array}{l}\text { Indicadores } \\
\text { de AC }\end{array}$ \\
\hline 54 & $\begin{array}{l}\text { Daniel: No laser os fótons estão todos } \\
\text { juntinhos? }\end{array}$ & & & $\begin{array}{l}\text { Levantamento } \\
\text { de hipótese }\end{array}$ \\
\hline 55 & $\begin{array}{l}\text { Professor: Não, laser a gente tem que pensar } \\
\text { na luz sendo onda. Na verdade, ora como } \\
\text { onda, ora como partícula. Bom, e aqui? Beatriz } \\
\text { S, compare essas duas figuras. [aponta para } \\
\text { as imagens da fig. 5.5] }\end{array}$ & Explorar & & \\
\hline 56 & $\begin{array}{l}\text { Beatriz: Na primeira, são circunferências } \\
\text { concêntricas e na segunda são conjuntos de } \\
\text { pontinhos... }\end{array}$ & & & $\begin{array}{l}\text { Organização de } \\
\text { informação }\end{array}$ \\
\hline 57 & Professor: E? Por quê? & Explorar & & \\
\hline 58 & Beatriz: Por que... & & & \\
\hline 59 & $\begin{array}{l}\text { Professor: Qual a relação? Por que forma essa } \\
\text { figura aqui e não aqui? [aponta para as } \\
\text { imagens da fig.5.5] }\end{array}$ & Explorar & $\begin{array}{l}\text { Pergunta } \\
\text { exploratória } \\
\text { sobre o } \\
\text { processo }\end{array}$ & \\
\hline 60 & Beatriz: Porque na primeira tem interferência. & & & Explicação \\
\hline
\end{tabular}

Do ponto de vista do conhecimento cientifico, enquanto produto socialmente aceito, fóton é uma partícula elementar de energia luminosa, ou seja, partícula de luz. Se a onda está sendo tratada como luz é bastante razoável que haja confusão em se igualar esses dois conceitos. Notemos então a pergunta do aluno Lucas feita ao professor: "No laser os fótons estão todos juntinhos?" (T54). 
O laser é uma fonte luminosa, mas a fim de diminuir polissemia em torno dos termos que estavam sendo utilizados naquela aula, adotou-se que laser era sinônimo de onda luminosa, ao passo que fóton equivaleria a uma partícula. A compreensão do aluno Lucas sobre esses elementos não é equivocada do ponto de vista canônico e poderia ser mais bem explorada, mas entrar nessa discussão provocaria um desvio da proposta da atividade. Dessa forma, o professor tenta ser sucinto em sua resposta e acaba não a respondendo a questão adequadamente (T55), pois qualquer que fosse a resposta dada forneceria uma das conclusões as quais se almeja que os alunos construíssem entendimento no fim da investigação que estava em curso. Assim, para dar fluidez à discussão e não desviar o foco da investigação em curso, o professor prossegue continuando a explorar os resultados do IMZ.
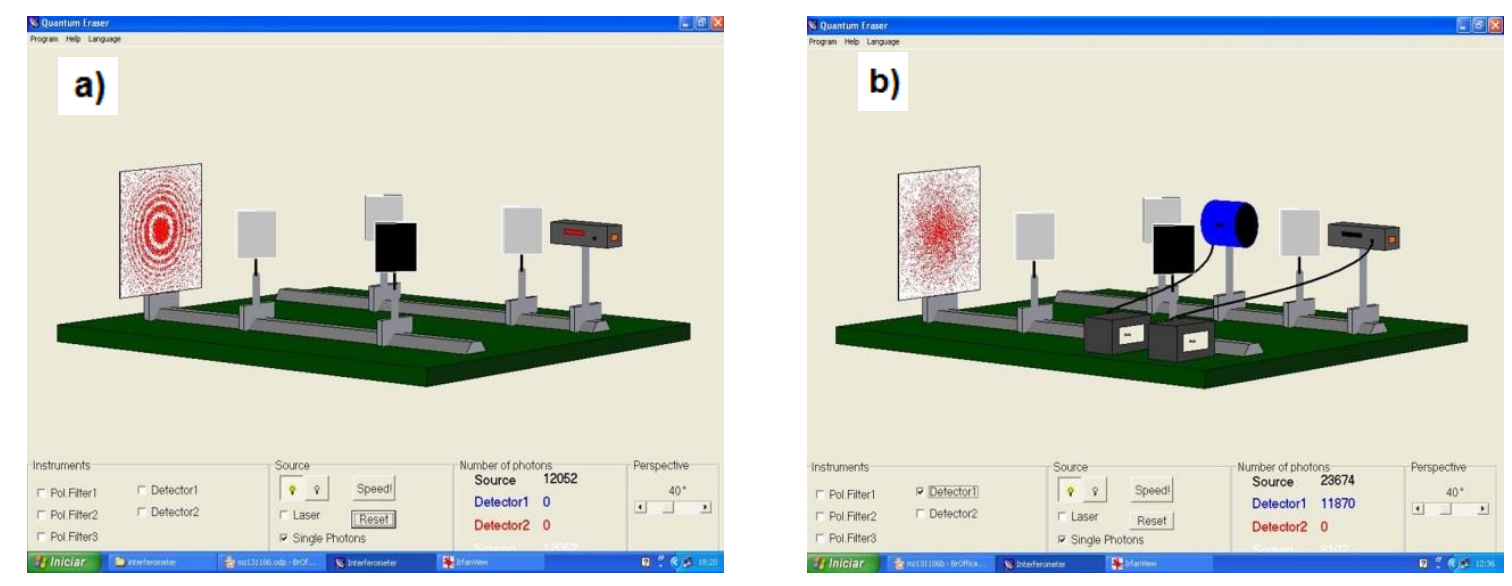

Figura 5.5 - Imagens utilizadas pelo professor para discutir resultados obtidos pelo IMZ considerando diferentes variáveis (turno $55 \mathrm{em}$ diante). A imagem a) representa do padrão de interferência formado com o aparato experimental em sua configuração inicial. Em b) um anteparo impede a passagem da luz por um dos caminhos o que resulta na ausência de um padrão de interferência.

O conceito de interferência é fundamental para a compreensão dos resultados do experimento e das quatro interpretações sobre a natureza da luz que está sendo investigada. Todavia, a questão de interferência entre partículas não é algo fácil de ser compreendido e representa uma incoerência para uma das interpretações que se almeja que os alunos construam entendimento. Com o intuito de destacar ainda mais alguns aspectos ligados a essa questão o professor continua a explorar os resultados obtidos pelo experimento buscando explicações para os resultados de duas outras situações (figura 5.5) (T55). 
A aluna Beatriz, conforme requerida pelo professor, fornece uma resposta a questão proposta: "Na primeira, são circunferências concêntricas e na segunda são conjuntos de pontinhos..." (T56).

É fácil inferir que a asserção proferida por Beatriz é apenas uma descrição da situação, pois conforme evidenciado pelo indicador de alfabetização científica, ela apenas organiza as informações contidas nas imagens e não as compara conforme solicitado. No entanto, o professor almeja mais que uma descrição e sim que seja evidenciada outras relações entre os objetos analisados. Dessa maneira, continua a explorar a situação por meio de uma pergunta exploratória sobre o processo direcionada aos alunos (T59): "Qual a relação? Por que forma essa figura aqui e não aqui?".

\begin{tabular}{|c|l|l|l|l|}
\hline \multicolumn{2}{|c|}{ Quadro 9-Trecho de falas da aula } & $\begin{array}{c}\text { Propósitos } \\
\text { Epistêmicos }\end{array}$ & $\begin{array}{c}\text { Tipo de } \\
\text { Pergunta }\end{array}$ & $\begin{array}{c}\text { Indicadores } \\
\text { de AC }\end{array}$ \\
\hline $\mathbf{T}$ & \multicolumn{1}{|c|}{ Falas Transcritas } & & & Explicação \\
\hline 63 & Professor: Fala, Lucas. & & \\
\hline 65 & $\begin{array}{l}\text { Lucas: Então, nos primeiros círculos as duas } \\
\text { se encontram, os dois raios estão juntos. }\end{array}$ & & & Explicação \\
\hline 66 & $\begin{array}{l}\text { Pucas: Enquanto que na outra figura [fig 5.5 - b] } \\
\text { como tem um detector ele impede a passagem } \\
\text { de um dos caminhos de chegar no anteparo, } \\
\text { então só tem um caminho que o fóton pode } \\
\text { passar. Por isso, ele não forma a figura. }\end{array}$ & & & \\
\hline 67 & $\begin{array}{l}\text { Professor: Tá. Então, nesse caso [aponta fig. } \\
\text { 5.5 b], não tem interferência, e aqui [aponta a } \\
\text { fig. 5.5 a] a gente tem interferência, não é isso? } \\
\text { Bom, agora o seguinte, o que a gente veio } \\
\text { conversando ao longo do ano inteirinho é que a } \\
\text { física pode explicar as coisas de duas } \\
\text { maneiras, ou como onda ou como partícula. }\end{array}$ & & & \\
Sintear & & & \\
\hline
\end{tabular}

A própria aluna Beatriz, conforme destacado no quadro anterior, apresentou uma resposta à pergunta do professor (T60), mas é nos turnos 64 e 66 que o aluno Lucas fornece uma explicação sobre a situação: "Então, nos primeiros círculos as duas se encontram, os dois raios estão juntos. (T64) (...) Enquanto que na outra figura (fig. 5.5.a) como tem um detector ele impede a passagem de um dos caminhos de chegar no anteparo, então só tem um caminho que o fóton pode passar. Por isso ele não forma a figura (T66)".

Notemos que a asserção proferida por Lucas é bastante confusa e dependente do contexto para ser compreendida, mas podem ser reescritas da seguinte maneira: No primeiro caso (fig. 5.5.a), os fótons podem seguir por dois caminhos e ao se encontrarem formam o padrão de interferência, enquanto que no outro caso (fig. 5.5.b), há um detector que impede a passagem de um dos 
fótons, fazendo com que chegue um fóton por vez no detector e não forme a imagem do padrão de interferência.

Organizando essa fala na forma de um argumento conforme o modelo de Toulmin, temos o seguinte esquema da figura 5.6.

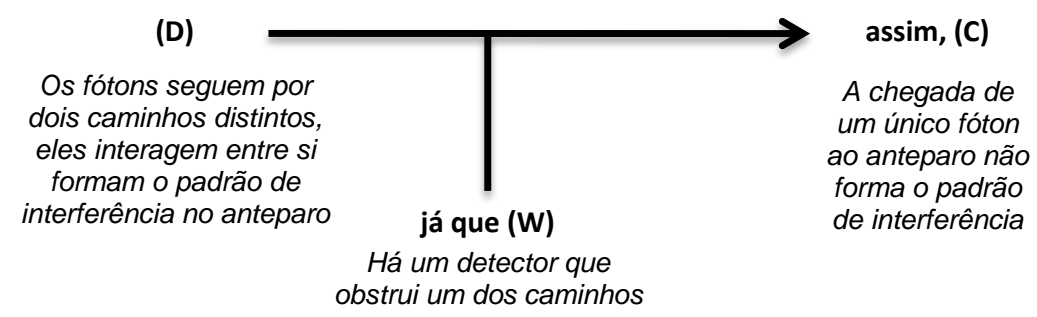

Figura 5.6 - Sistematização da asserção do aluno Lucas (T64 e T65)

Resgatando alguns pontos que foram tratados até esse momento da aula, tivemos que a discussão se iniciou apresentando características e resultados do IMZ. Ainda no início da investigação a luz havia sido tratada como sendo onda o que permitiu a retomada dos dados $\mathrm{D}$, referentes a características do IMZ e resultados gerados ao longo do processo de investigação da luz, a garantia $\mathrm{W}_{1}$ e o apoio $\mathrm{B}_{1}$, que expressam aspectos da interação entre ondas e conceitos da teoria ondulatória (ver fig. 5.2, p.93). A partir de um determinado instante, o professor passou a tratar a luz como partícula e buscou retomar mais informações ligadas ao experimento explorando as implicações que essa mudança ocasionaria no resultado. A explicação dada pelo aluno Lucas mencionada acima apesar de confusa é bastante coerente e completa, e é construída com base em um dado que se apoia em uma garantia para formar uma conclusão, ou seja, forma um argumento.

Como dito, a ideia central dessa asserção é dificil de ser compreendida, mas foi clara o bastante para o professor que, como vemos no turno 67, qualifica e sintetiza a fala de Lucas. Por meio da análise do argumento da figura 5.6 construído com base na fala de Lucas (T64 e T66), da fala do professor (T67) e também retomando o argumento da figura 5.2, vemos que nesse momento são colocados em evidência a garantia $\mathrm{W}_{2}$ e $\mathrm{o}$ apoio $\mathrm{B}_{2}$, que descrevem respectivamente o fato de que dois ou mais fótons podem sofrem interferência tomando conceitos da teoria quântica como apoio, complementando a conclusão $C$, na qual está expresso que a luz pode ter de onda e de partícula e que 
anteriormente só teve a questão do comportamento ondulatório discutido e apresentado pelos alunos. É importante destacar nesse ponto que, a fala do aluno Lucas só foi compreendida pelo professor, pois ele tinha pleno conhecimento sobre a situação o que nos mostra a necessidade de um professor estar bem preparado frente a diferentes nuances que se relacionam ao objeto de investigação que será estudado em sala de aula. Em outras palavras, a abordagem investigativa exige que o professor esteja atento as contribuições dos alunos, sejam elas certas ou erradas, e, principalmente, saiba quais são as situações limites que merecem ser evidenciadas durante o processo investigativo.

Outro ponto a ser mais bem observado nesse instante é que a fala do aluno Lucas é classificada como uma explicação, conforme expresso pelos indicadores de alfabetização científica. Apesar de Sasseron (2008) não ter dado foco à relação que essa destreza tem com o processo argumentativo, vemos que, foi o entrecruzamento de variáveis e informações que possibilitou a construção de um argumento, conforme o modelo de Toulmin.

\subsection{2.a. Sintese do episódio 2}

Após o encerramento da análise deste episódio que compreende do turno de fala 33 ao turno 68 e detalhada na Tabela 5.2 as categorizações realizadas, é possivel notar que o propósito epistêmico explorar foi o mais frequente, com sete ocorrências.

Com relação ao tipo de perguntas do professor, as perguntas sobre dados apareceram em maior número, mas também houve o primeiro aparecimento de uma pergunta exploratória sobre o processo. Por fim, os indicadores de alfabetização científica identificados nas falas dos alunos foram: organização e classificação de informações, ligados ao trabalho com dados empíricos, totalizando 5 ocorrências; levantamento de hipóteses, ligados a obtenção de dados, com 1 ocorrência; os indicadores explicação e justificativa, relacionados ao entrecruzamento de variáveis e informações, que foram os mais frequentes com 7 ocorrências; por fim, ainda que apenas uma vez, também houve a ocorrência do indicador raciocínio lógico, que marca o início da apropriação das ideias em discussão em caráter científico. 
Quadro 10 - Mapa do episódio 2: Classificação dos turnos de fala de alunos e professor segundo as categorias metodológicas selecionadas.

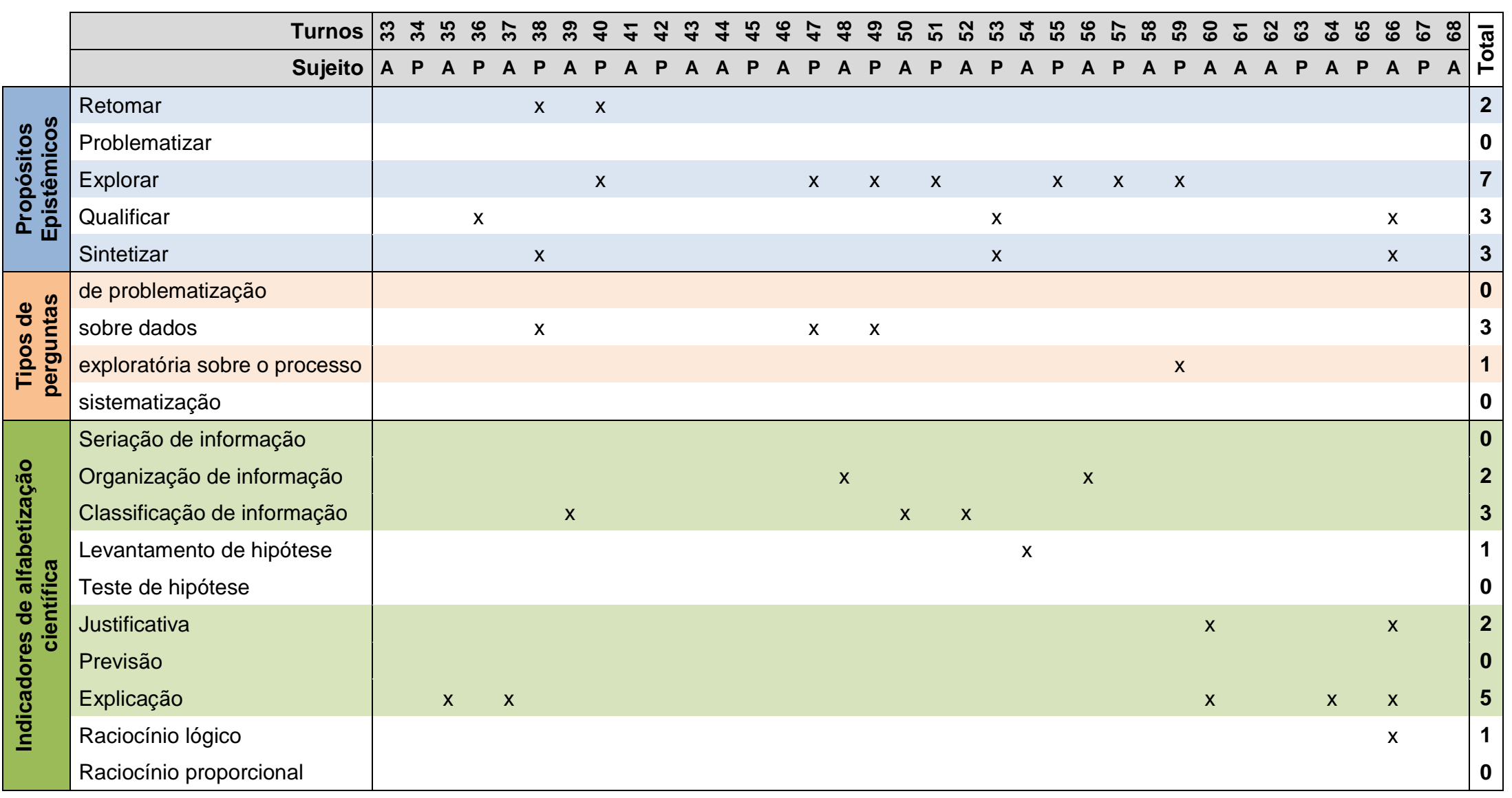


A forma como o professor interagia com seus alunos, possibilitou que estes emitissem contribuições de distintas naturezas e que puderam ser categorizadas com diferentes indicadores de alfabetização científica. À luz da análise feita com o apoio dos indicadores, vimos que os indicadores explicação e justificativa foram os mais recorrentes e que a presença do indicador raciocinio lógico nos permite inferir que a ocorrência concomitante dessas categorias indicam a presença de argumentos nas falas dos alunos. Foi, já neste episódio, nos turnos 64 e 65, que as falas do aluno Lucas puderam ser enquadradas na forma de um argumento conforme o modelo de Toulmin, pois era dotada de dado, garantia e conclusão.

Notemos, também, que apesar de as ações do professor indicarem que seu objetivo era a retomada de informações, grande parte desse processo já havia sido feito no início da aula, descrita no episódio anterior. Assim, considerando o argumento da figura 5.2 (p.93), nesse segundo momento temos que o dado (D) "utilizando o IMZ para investigar a luz encontramos um padrão de interferência como resultado" - já era de conhecimento de todos os alunos e a discussão que se desenvolveu foi toda ancorada nessa informação, o que possibilitou evidenciar as garantias e os apoios $\left(\mathrm{W}_{1}, \mathrm{~W}_{2}, \mathrm{~B}_{1}\right.$ e $\left.\mathrm{B}_{2}\right)$ necessários ao desenvolvimento da investigação e construção de entendimento pelos alunos.

Essa ocorrência em maior número do propósito explorar, com sete ocorrências, por fim, pode ser justificada pelo fato de que o professor já tinha retomado algumas das características principais do IMZ e, portanto, fez-se necessário trazer à investigação novos pontos de vista sobre o experimento em discussão. Ainda que talvez seja uma conclusão precipitada, vemos também que o propósito de explorar tem uma ligação com as perguntas sobre dados, mas pode ser o precursor para o surgimento de perguntas exploratórias sobre processo, pois ao trazer à discussão diferentes situações de investigação, o professor favorece o surgimento de explicações menos superficiais dadas pelos alunos.

\subsubsection{EPISÓdIO 3 - EvIDENCIANDO INCOERÊNCIAS}

Até esse momento da aula, a preocupação central do professor era com o processo de retomada de características do IMZ. Nesse sentido, foi possível explicitar diferentes dados durante a discussão e construir garantias que são 
essenciais ao entendimento pelos alunos do problema da aula: descrever as quatro interpretações dadas pela mecânica quântica ao comportamento dual da luz.

Estabelecido o panorama anterior, a investigação da aula tem continuidade com o professor propondo um novo problema aos alunos.

\begin{tabular}{|c|c|c|c|c|}
\hline \multicolumn{5}{|c|}{ Quadro 11 - Trecho de falas da aula } \\
\hline$T$ & Falas Transcritas & $\begin{array}{l}\text { Propósitos } \\
\text { Epistêmicos }\end{array}$ & $\begin{array}{l}\text { Tipo de } \\
\text { Pergunta }\end{array}$ & $\begin{array}{l}\text { Indicadores } \\
\text { de AC }\end{array}$ \\
\hline 69 & $\begin{array}{l}\text { Professor: Não, as coisas, no geral. Pra luz, } \\
\text { em particular, nós chegamos numa } \\
\text { encruzilhada. Nós chegamos numa } \\
\text { encruzilhada agora. A Bia, se eu não me } \\
\text { engano na aula passada, no finalzinho da aula, } \\
\text { colocou exatamente qual era o nosso } \\
\text { problema. Como é que eu explico, se eu } \\
\text { pensar que a luz é uma partícula e o fóton é } \\
\text { uma partícula, como é que eu explico a } \\
\text { interferência pra um único fóton? Então, é isso } \\
\text { que a mecânica quântica vai tentar conversar } \\
\text { com a gente. }\end{array}$ & $\begin{array}{l}\text { Qualificar } \\
\text { Problematizar }\end{array}$ & $\begin{array}{l}\text { Pergunta de } \\
\text { problematização }\end{array}$ & \\
\hline 70 & Vitor: Explicar como eles passam. & & & \\
\hline 71 & $\begin{array}{l}\text { Professor: Não, um único. Como é que um } \\
\text { fóton interfere com ele mesmo. [inaudível, } \\
\text { vários alunos falam ao mesmo tempo] Não, } \\
\text { não, peraí. Pessoal, diferente do que eles tão } \\
\text { dizendo aqui, não é quando a gente tem assim, } \\
\text { ah, eu tenho a luz interagindo com outra coisa, } \\
\text { aí você tá aumentando as variáveis. Nós } \\
\text { estamos pensando assim, olha... Foi isso que a } \\
\text { Bia discutiu aqui na ultima aula. Como é que } \\
\text { eu explico interferência para um único fóton? } \\
\text { Ele com ele mesmo. Na nossa figurinha lá, se } \\
\text { eu lançar apenas um único fóton, entendeu? } \\
\text { Diferente do que a gente tinha no real, que a } \\
\text { gente manda um feixe, a gente tá mandando } \\
\text { milhões ao mesmo tempo e aí eu posso } \\
\text { continuar pensando em bolinhas colidindo uma } \\
\text { com a outra, né? Agora não, eu tenho um } \\
\text { único e nesse único eu continuo tendo } \\
\text { interferência. }\end{array}$ & $\begin{array}{l}\text { Problematizar } \\
\text { Retomar } \\
\text { Qualificar }\end{array}$ & & \\
\hline
\end{tabular}

Resgatando a explicação do aluno Lucas (T64 e T66) em que, por meio da análise dos resultados obtidos pelo IMZ quando se trabalhava com fótons, concluiu-se que era necessário mais que um fóton para que se obtivesse a imagem do padrão de interferência, vemos que a problematização feita pelo professor é feita com base nessa informação e, apesar de bastante longa, nos permite observar alguns elementos importantes para que os alunos compreendam a questão proposta. Explicitemos a seguir esses elementos citando trechos das falas do próprio professor nos turnos 69 e 71 : 
[...] Pra luz, em particular, nós chegamos numa encruzilhada. [...] Como é que eu explico, se eu pensar que a luz é uma partícula e o fóton é uma particula, [...] interferência pra um único fóton? Então, é isso que a mecânica quântica vai tentar conversar com a gente. (T69) [...] Como é que um fóton interfere com ele mesmo. [...] Diferente do que a gente tinha no real, que a gente manda um feixe, a gente tá mandando milhões ao mesmo tempo e aí eu posso continuar pensando em bolinhas colidindo uma com a outra, né? Agora não, eu tenho um único e nesse único eu continuo tendo interferência. (T71)

Com base no trecho destacado, vemos que por meio de uma pergunta de problematização, o professor problematiza a situação a ser investigada: "Como é que eu explico a interferência de um único fóton?". Essa questão é essencial para que se evidenciem aspectos relacionados às incoerências presentes nas interpretações dadas pela mecânica quântica que está sendo investigado. Em outras palavras, esse problema permite que o professor coloque em discussão situações limites do experimento e das conclusões a serem construídas, pois evidencia aspectos que a física clássica que não prevê, sendo necessário que se recorra a conceitos da física quântica. Essa distinção entre física clássica e física quântica e a necessidade de se considerar apoios não clássicos é qualificada pelo professor quando ele delimita o contexto de investigação em sua fala: "Então é isso que a mecânica quântica vai tentar conversar com a gente” (T69).

Outro ponto bastante importante nesse instante, também relacionado a delimitação do contexto de investigação em curso, é o fato de que, ao propor o problema o professor retoma novamente as informações trazidas nos momentos anteriores da aula: "Diferente do que a gente tinha no real, que a gente manda um feixe, a gente tá mandando milhões ao mesmo tempo e aí eu posso continuar pensando em bolinhas colidindo uma com a outra, né?” (T71). Notemos que são destacadas informações referentes aos resultados obtidos por meio do IMZ e que já foram colocadas em discussão no início da aula, trazidas em sua maioria pelos próprios alunos e que explicitam situações de contorno, no qual as conclusões tidas anteriormente não são válidas.

É importante destacar nesse momento que o propósito problematizar é claramente ancorado nas contribuições trazidas pelos alunos. Esse fato nos mostra características essenciais para o desenvolvimento de uma atividade investigativa, pois as interações aluno-aluno e aluno professor que são as 
geradoras de questões e, consequentemente, fomentam e direcionam o curso da investigação.

Dada essas conjecturas, podemos refrasear a fala do professor da seguinte maneira: "Considerando o IMZ, ao utilizarmos um feixe de fótons obtemos o resultado do padrão de interferência porque os fótons interagem entre si. Mas, como é possível encontrarmos o mesmo resultado utilizando apenas um fóton?".

\begin{tabular}{|c|c|c|c|c|}
\hline \multicolumn{5}{|c|}{ Quadro 12 - Trecho de falas da aula } \\
\hline $\mathbf{T}$ & Falas Transcritas & $\begin{array}{l}\text { Propósitos } \\
\text { Epistêmicos }\end{array}$ & $\begin{array}{l}\text { Tipo de } \\
\text { Pergunta }\end{array}$ & $\begin{array}{l}\text { Indicadores } \\
\text { de AC }\end{array}$ \\
\hline 72 & Beatriz: Ele se dividiu ao meio. & & & $\begin{array}{l}\text { Levantamento } \\
\text { de hipótese }\end{array}$ \\
\hline 73 & $\begin{array}{l}\text { Professor: Quando ele passa lá } \\
\text { semiespelho ele se divide em duas partes? }\end{array}$ & Explorar & & \\
\hline 74 & Beatriz: $\hat{E}_{\ldots} .$. & & & $\begin{array}{l}\text { Levantamento } \\
\text { de hipótese }\end{array}$ \\
\hline 75 & $\begin{array}{l}\text { Professor: Mas duas partes do que? De } \\
\text { partícula? Duas partes de onda? Uma parte } \\
\text { partícula outra parte onda? }\end{array}$ & Explorar & $\begin{array}{l}\text { Pergunta de } \\
\text { problematização }\end{array}$ & \\
\hline 76 & Beatriz: Acho que as duas partes partícula. & & & $\begin{array}{l}\text { Levantamento } \\
\text { de hipótese }\end{array}$ \\
\hline 77 & $\begin{array}{l}\text { Professor: Mas aí se ele se dividir ao meio, eu } \\
\text { deixo de ter um fóton e tenho dois. Dois meio } \\
\text { fótons... }\end{array}$ & $\begin{array}{l}\text { Explorar } \\
\text { Sintetiza }\end{array}$ & & \\
\hline 78 & Beatriz: Aí depois eles se juntam. & & & $\begin{array}{l}\text { Levantamento } \\
\text { de hipótese }\end{array}$ \\
\hline 79 & Professor: Junta aqui embaixo de novo? & Explorar & & \\
\hline 80 & Beatriz: É, os dois lados. & & & Previsão \\
\hline 81 & $\begin{array}{l}\text { Professor: Mas como é que com eles juntos eu } \\
\text { posso ter no anteparo dos dois lados? Aqui... } \\
\text { Olha, a Bia ta dizendo o seguinte, aqui ele se } \\
\text { divide, certo? Aí vem pra cá e vem pra cá. } \\
\text { Quando chega aqui, se eles se juntam, como a } \\
\text { Bia ta falando, eu teria que ter observação em } \\
\text { um único anteparo, mas eu consigo medir nos } \\
\text { dois ao mesmo tempo. }\end{array}$ & $\begin{array}{l}\text { Sintetizar } \\
\text { Explorar }\end{array}$ & $\begin{array}{l}\text { Pergunta de } \\
\text { problematização }\end{array}$ & \\
\hline
\end{tabular}

O objetivo do professor nesse momento era tornar claro o objeto investigado. Dessa forma, suas ações partiram de perguntas de problematização e, principalmente, ações relacionadas ao propósito explorar. Assim, a aluna Beatriz foi motivada a emitir sua hipótese sobre a situação o que possibilitou a obtenção de uma previsão sobre a situação. Assim, em resposta a problematização feita pelo professor (T69 e T71), a aluna Beatriz, ainda que almejasse explicar o fenômeno de interferência entre um único fóton, fornece um dos primeiros argumentos da aula (T72, T74, T76, T78 e T80).

Mesmo não sendo possivel encontrar todos os elementos do padrão de argumento Toulmin na fala da aluna Beatriz é possivel inferir que as garantias e apoios, os quais sustentam a passagem dos dados á sua conclusão, são plenamente conhecidos pelos demais participantes da discussão. Assim, 
podemos organizar a sua fala conforme o padrão de argumento de Toulmin, expresso na figura 5.7 abaixo.

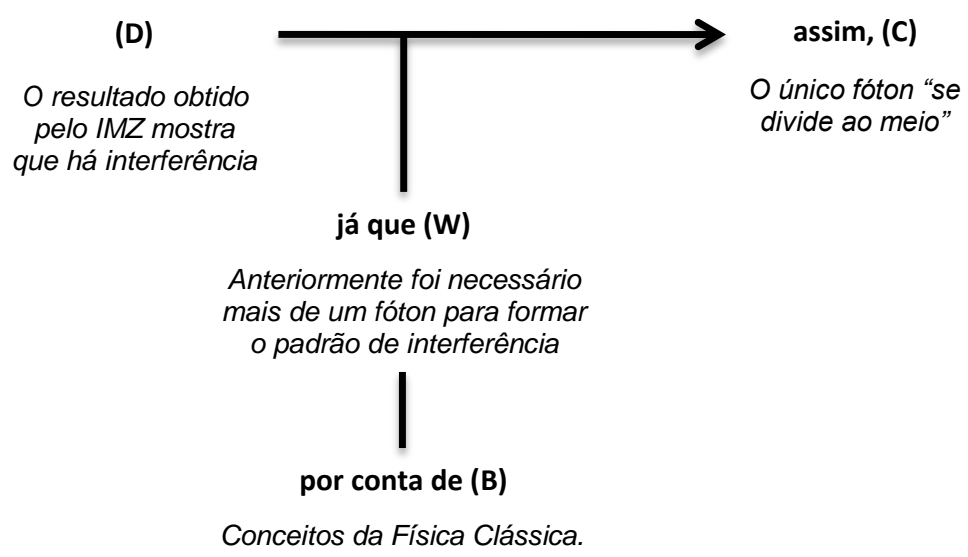

Figura 5.7 - Argumento construído em coletivamente e emitido pela aluna Beatriz (entre os turnos 72 e 80) em resposta ao problema da interação com um único fóton, proposto pelo professor.

Outro ponto que merece atenção em nossa análise é o fato de que, a asserção de Beatriz expressa uma conclusão sobre a qual ela mesma possui dúvidas, pois parte de hipóteses sobre a situação e prevê uma conclusão, ainda desconhecida. Dessa forma, poderia ser incluído um qualificador (Q) à sistematização do argumento conforme o modelo de Toulmin. Vejamos que incluir o qualificador "presumivelmente" está em consonância com o indicador de alfabetização científica previsão encontrado em sua fala. Obviamente que essa afirmação não pode ser feita apenas com base na análise da resposta da aluna, "Ele [o fóton] se dividiu ao meio", mas sim por meio da compreensão do contexto da discussão. Todavia, optamos por não incluir essa interpretação no esquema da figura 5.7, pois mesmo com todas as evidências que ressaltamos, poderiamos incorrer na construção de uma conclusão não coerente com o rigor que deve ser tomado no desenvolvimento de uma pesquisa.

Prosseguindo a análise com o foco nas ações do professor, nesse mesmo trecho também se pode observar que, com o intuito de explorar e sintetizar o ponto de vista da aluna Beatriz, o professor faz questionamentos para que ela evidencie as razões e justificativas de sua conclusão. É importante destacar que essa ação, além de, como dito, explicitar justificativas, garante a compreensão da contribuição de Beatriz pelos demais alunos da turma, favorecendo o surgimento de novas contribuições. É válido mencionar que nesse momento, o objetivo do 
professor é construir junto aos alunos o entendimento de incoerências das interpretações da mecânica quântica.

Nos turnos seguintes, alguns alunos continuam a emitir algumas hipóteses e previsões sobre o problema proposto nos turnos 69 e 70, e o professor, mediando a investigação e explorando os pontos de vista desses alunos, analisa cada situação colocada em discussão, não qualificando as contribuições como corretas ou erradas. No final desse episódio, mesmo sem sintetizar as contribuições emitidas, a investigação tem continuidade com o professor retomando novamente o problema central da aula.

\subsection{3.a. Sintese do episódio 3}

Finalizando a análise deste episódio, que corresponde aos turnos 69 a 98, vimos que, considerando como referência a categorização das falas do professor segundo os propósitos epistêmicos para promoção da argumentação, o propósito explorar, novamente, foi o mais frequente, apresentando dez ocorrências. Todavia, conforme expresso na tabela 5.3, ações típicas referentes a cada um dos cinco propósitos epistêmicos existentes foram encontrados ao longo dos turnos que correspondem a esse terceiro momento.

Com relação aos tipos de perguntas, ocorreram as primeiras perguntas sobre problematização, o que nos dá indícios de que a investigação estava em um momento avançado de desenvolvimento. Em outras palavras, elencados os dados e informações importantes ao processo, o problema a ser investigado começa a ganhar estrutura que possibilitaria que os alunos pudessem conduzir as etapas ulteriores de investigação e, consequentemente, engajamento no processo de construção de entendimento sobre os objetos em estudo.

Os indicadores de alfabetização científica mais frequentes foram os relacionados à obtenção de dados empíricos e delimitação de variáveis: levantamento e teste de hipóteses, com, respectivamente, 6 e 1 ocorrências. Houve também a presença de indicadores relacionados ao entrecruzamento de variáveis e informações: justificativa e previsão.

Foi possivel observar também a elaboração de um argumento, proferido pela aluna Beatriz (figura 5.7, p.113) no intercurso do processo investigativo mediado e conduzido pelo professor. Dos turnos de fala 72 a 80 , referentes à construção deste argumento, é possivel notar que o professor usou 
Quadro 13 - Mapa do episódio 3: classificação dos turnos de fala de alunos e professor segundo as categorias metodológicas selecionadas.

\begin{tabular}{|c|c|c|c|c|c|c|c|c|c|c|c|c|c|c|c|c|c|c|c|c|c|c|c|c|c|c|c|c|c|c|}
\hline & Turnos & 8 & $\bar{\kappa}$ & N & $\Re$ & $\mathbb{1}$ & $\stackrel{n}{\wedge}$ & $\stackrel{0}{R}$ & $\hat{N}$ & $\stackrel{\infty}{N}$ & 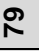 & ০ & $\bar{\infty}$ & $\approx$ & ஜ & 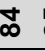 & & 0 & & $\infty$ & & ஃ & & ชั & ת & ठ & 뇽 & ஜ & ๙ీ ః & $\pi$ \\
\hline & Sujeito & P A & $\mathbf{P}$ & A & $\mathbf{P}$ & A & $\mathbf{P}$ & A & $\mathbf{P}$ & A & $\mathbf{P}$ & A & $\mathbf{P}$ & A & $\mathbf{P}$ & A & $\mathbf{P}$ & A & $\mathbf{P}$ & A & $\mathbf{P}$ & A & $\mathbf{P}$ & A & $\mathbf{P}$ & A & A & A & $\mathbf{P} \mathbf{A}$ & $\stackrel{0}{-}$ \\
\hline \multirow{5}{*}{ 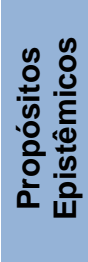 } & Retomar & & $x$ & & & & & & & & & & & & & & & & & & & & & & & & & & & 1 \\
\hline & Problematizar & $x$ & $x$ & & & & & & & & & & & & & & & & $x$ & & & & & & & & & & & 3 \\
\hline & Explorar & & & & $x$ & & $x$ & & $x$ & & $x$ & & $x$ & & & & $x$ & & $x$ & & $x$ & & & & $x$ & & & & $x$ & 10 \\
\hline & Qualificar & $x$ & $x$ & & & & & & & & & & & & & & & & & & & & & & & & & & & 2 \\
\hline & Sintetizar & & & & & & & & $x$ & & & & $x$ & & & & & & & & & & & & & & & & & 2 \\
\hline \multirow{4}{*}{ 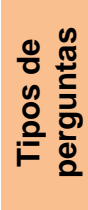 } & de problematização & $x$ & & & & & $x$ & & & & & & & & & & & & & & & & & & & & & & & 2 \\
\hline & sobre dados & & & & & & & & & & & & & & & & & & & & & & & & & & & & & 0 \\
\hline & exploratória sobre o processo & & & & & & & & & & & & & & & & & & $x$ & & & & & & & & & & & 1 \\
\hline & sistematização & & & & & & & & & & & & & & & & & & & & & & & & & & & & & 0 \\
\hline \multirow{10}{*}{ 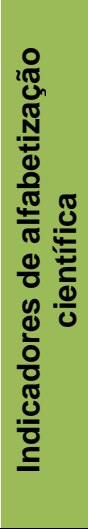 } & Seriação de informação & & & & & & & & & & & & & & & & & & & & & & & & & & & & & 0 \\
\hline & Organização de informação & & & & & & & & & & & & & & & & & & & & & & & & & & & & & 0 \\
\hline & Classificação de informação & & & & & & & & & & & & & & & & & & & & & & & & & & & & & 0 \\
\hline & Levantamento de hipótese & & & $x$ & & $x$ & & $x$ & & $x$ & & & & $x$ & & & & & & & & & & & & & $x$ & & & 6 \\
\hline & Teste de hipótese & & & & & & & & & & & & & & & $x$ & & & & & & & & & & & & & & 1 \\
\hline & Justificativa & & & & & & & & & $x$ & & & & & & & & & & & & & & & & & & & & 1 \\
\hline & Previsão & & & & & & & & & & & $x$ & & & & & & $x$ & & & & & & & & & & & & 2 \\
\hline & Explicação & & & & & & & & & & & & & & & & & & & & & & & & & & & & & 0 \\
\hline & Raciocínio lógico & & & & & & & & & & & & & & & & & & & & & & & & & & & & & 0 \\
\hline & Raciocínio proporcional & & & & & & & & & & & & & & & & & & & & & & & & & & & & & 0 \\
\hline
\end{tabular}


essencialmente do propósito explorar e por meio de perguntas de problematização favoreceu o desenvolvimento das hipóteses da aluna sobre uma dada situação até que ela fosse capaz de apresentar suas ideias em completude, com os devidos aportes necessários para dar força a sua conclusão.

Um ponto de destaque nesse episódio é o fato de que a exploração feita pelo professor usava sempre de informações trazidas pela própria aluna, o que nos mostra uma característica importante para que a argumentação dos estudantes seja bem sucedida durante uma atividade que se baseie no ensino por investigação.

\subsubsection{EPISÓDIO 4 - AS QUATRO INTERPRETAÇÕES DA QUÂNTICA}

O início desse episódio é marcado pela proposição do problema central da aula aos alunos. Esse momento é essencial por diversas razões, mas principalmente devido ao fato de que são as respostas a esse problema que deverão indicar a compreensão dos alunos sobre o objeto de investigação.

\begin{tabular}{|c|l|l|l|l|}
\hline \multicolumn{2}{|c|}{ Quadro 14-Trecho de falas da aula } & $\begin{array}{c}\text { Propósitos } \\
\text { Epistêmicos }\end{array}$ & $\begin{array}{c}\text { Tipo de } \\
\text { Pergunta }\end{array}$ & $\begin{array}{c}\text { Indicadores } \\
\text { de AC }\end{array}$ \\
\hline $\mathbf{T}$ & \multicolumn{1}{|c|}{ Falas Transcritas } & & \\
& $\begin{array}{l}\text { Professor: Tinha também. Vamos pensar o } \\
\text { seguinte, olhando aí pro quadrinho de vocês } \\
\text { [faz referência a folha da atividade de } \\
\text { sistematização que os alunos tem em mãos], } \\
\text { tá? Existem várias interpretações pra essa } \\
\text { situação, tá? A mecânica quântica apresenta } \\
\text { quatro em particular. Elas são as quatro mais } \\
\text { discutidas. Quatro possíveis pensamentos pra } \\
\text { gente tentar entender a natureza da luz. }\end{array}$ & $\begin{array}{l}\text { Qualificar } \\
\text { Problematizar }\end{array}$ & & \\
\hline 100 & Beatriz: Existem outras? & & & \\
\hline 101 & $\begin{array}{l}\text { Professor: Existem, mas assim, as quatro } \\
\text { principais são essas aqui. Não é pra copiar. }\end{array}$ & Qualificar & & \\
\hline
\end{tabular}

A proposição do problema tem início com o professor pontuando as quatro interpretações dadas pela mecânica quântica (ondulatória, corpuscular, complementaridade e dualista-realista) fazendo referência à atividade de sistematização que os alunos tinham em mãos (disponível no anexo B) e a apresentação Power Point ${ }^{\circledR}$ que vinha utilizando desde o começo da aula. Em seguida (T99 e T101) o professor utiliza do propósito epistêmico qualificar para delimitar o contexto de investigação, ou seja, destacar que as considerações a serem proferidas devem levar em conta arcabouços da física quântica e não da física clássica. 
Nesse trecho é importante frisar que, considerando o total de aproximadamente 300 turnos de fala que compõe o nosso material de análise, o problema central surge após ter-se passado cerca de um terço da aula. Esse aspecto nos permite interpretar, dentre outras coisas, a importância do processo de retomada para o desenvolvimento de uma atividade de investigação, sem o qual não seria possível que os alunos compreendessem a real natureza do problema de investigação.

Após o professor fazer a problematização inicial, a aluna Beatriz (T100) exibe uma dúvida bastante genuína: "Existem outras [interpretações para explicar a natureza da luz]?". No turno seguinte é possivel observar que o professor qualifica novamente o objeto de investigação, delimitando o contexto da investigação e destacando que, de fato, existem outras interpretações possiveis, mas que apenas as quatro que foram apresentadas serão discutidas.

Nos turnos 55 e 56 tivemos uma situação semelhante a essa do turno 100 e 101. A questão feita pelo aluno Lucas ao professor no turno 54, "no laser os fótons estão todos juntinhos?”, como discutido, mostra a dúvida do aluno com relação às variáveis utilizadas na investigação, ocasionada, provavelmente, pelos termos utilizados na aula (laser correspondente à luz como onda, enquanto fóton correspondente à luz como partícula). Essa colocação poderia abrir precedente a uma longa discussão que estava fora dos objetivos da aula, assim o professor emite uma breve resposta a questão de Lucas e dá continuidade à investigação para não interromper o curso do processo. Já nos turnos 100 e 101, ocorre algo parecido, pois novamente, discutir outras interpretações possiveis interpretações sobre a natureza dual da luz estava fora do planejamento da aula, assim, para não prejudicar a fluidez da discussão e o fluxo de interações o professor delimita o contexto de investigação utilizando do propósito epistêmico qualificar.

\begin{tabular}{|c|l|l|l|l|}
\hline \multicolumn{2}{|c|}{ Quadro 15 - Trecho de falas da aula } & $\begin{array}{c}\text { Propósitos } \\
\text { Epistêmicos }\end{array}$ & $\begin{array}{c}\text { Tipo de } \\
\text { Pergunta }\end{array}$ & $\begin{array}{c}\text { Indicadores } \\
\text { de AC }\end{array}$ \\
\hline 105 & $\begin{array}{l}\text { Professor: Já tava com a caneta pronta... } \\
\text { Vamos pensar antes da gente olhar lá o que tá } \\
\text { escrito. A gente tem uma interpretação que } \\
\text { recebe o nome de ondulatória. Segundo essa } \\
\text { interpretação a luz é? }\end{array}$ & $\begin{array}{l}\text { Pergunta } \\
\text { exploratória } \\
\text { sobre o } \\
\text { processo }\end{array}$ & \\
\hline 106 & Alunos: Onda. & & & $\begin{array}{l}\text { Classificação } \\
\text { de informação }\end{array}$ \\
\hline 107 & $\begin{array}{l}\text { Professor: A gente tem uma interpretação que } \\
\text { é a corpuscular. }\end{array}$ & Problematizar & & $\begin{array}{l}\text { Classificação } \\
\text { de informação }\end{array}$ \\
\hline 108 & Lucas: Partícula. São os fótons! & & \\
\hline 109 & Professor: São fótons. Fóton é uma partícula & Sintetizar & & \\
\hline
\end{tabular}




\begin{tabular}{|c|c|c|c|c|}
\hline & $\begin{array}{l}\text { de luz! Existe uma interpretação... Vou pular } \\
\text { pra ultima... Dualista. }\end{array}$ & Problematizar & & \\
\hline 110 & Bruna: Ora como onda e como partícula. & & & $\begin{array}{l}\text { Classificação } \\
\text { de informação }\end{array}$ \\
\hline 111 & Beatriz: Onda e Partícula. & & & $\begin{array}{l}\text { Classificação } \\
\text { de informação }\end{array}$ \\
\hline 112 & Lucas: É onda e partícula? & & & $\begin{array}{l}\text { Levantamento } \\
\text { de hipótese }\end{array}$ \\
\hline 113 & $\begin{array}{l}\text { Professor: Que ela pode ser as duas coisas ao } \\
\text { mesmo tempo. E uma partícula que é } \\
\text { associada com uma onda ou uma onda com } \\
\text { uma partícula... }\end{array}$ & Sintetizar & & \\
\hline 114 & Alunos: Inaudível. & & & \\
\hline 115 & $\begin{array}{l}\text { Pedro: Você falou que não tem como, que não } \\
\text { pode ser onda e partícula ao mesmo tempo. }\end{array}$ & & & \\
\hline 116 & $\begin{array}{l}\text { Professor: Então, aí cai nessa situação que o } \\
\text { Pedro ta falando, né? }\end{array}$ & Explorar & & \\
\hline 117 & Beatriz: Ela é uma coisa e outra. & & & \\
\hline 118 & $\begin{array}{l}\text { Professor: É... Pra mecânica clássica isso não } \\
\text { é possível. }\end{array}$ & Qualificar & & \\
\hline 119 & Beatriz: Mas e em Quântica... & & & \\
\hline 120 & Pedro: Acho que é. & & & $\begin{array}{l}\text { Levantamento } \\
\text { de hipótese }\end{array}$ \\
\hline 121 & $\begin{array}{l}\text { Professor: Mas em física moderna a gente vai } \\
\text { ter que arrumar uma nova explicação. E essa } \\
\text { nova explicação, então, pode ser que ela seja } \\
\text { as duas coisas ao mesmo tempo? }\end{array}$ & Problematizar & & \\
\hline 122 & Beatriz S: Acho que sim. & & & $\begin{array}{l}\text { Levantamento } \\
\text { de hipótese }\end{array}$ \\
\hline 123 & Professor: E complementaridade? & Problematizar & $\begin{array}{l}\text { Pergunta } \\
\text { exploratória } \\
\text { sobre o } \\
\text { processo }\end{array}$ & \\
\hline 124 & Pedro: As duas se complementam. & & & $\begin{array}{l}\text { Levantamento } \\
\text { de hipótese }\end{array}$ \\
\hline
\end{tabular}

Resgatando características das interpretações investigadas, ressaltamos que as interpretações ondulatória e corpuscular possuem descrições bastante objetivas, uma vez que suas características são análogas a características de fenômenos da física clássica. Assim, nos turnos 106 e 108, após o professor problematizar a situação por meio de uma pergunta exploratória sobre o processo (T105 e T107), os alunos facilmente emitem as respostas adequadas.

Um aspecto importante a ser mencionado nesse ponto diz respeito a categorização da fala do professor no turno 105. Em um primeiro momento é possivel pensa-la como uma ação de retomada, pois os alunos têm conhecimento sobre a questão que está sendo lançada na discussão. Todavia, do ponto de vista da física e do conhecimento científico, definir a natureza ondulatória da luz é um problema e é esta uma das questões que representam o problema central da aula e está sendo investigada naquele momento. Dado essas considerações, classificar o turno com o propósito epistêmico retomar tornaria a análise inconsistente.

Prosseguindo, vemos que após as respostas dadas pelas alunas Bruna e Beatriz (T110 e T111), o aluno Lucas (T112) coloca uma dúvida que surge em 
decorrência da não trivialidade da interpretação dualista-realista: "[a luz] É onda e partícula?".

A interpretação dualista-realista descreve a luz como sendo um ente físico de duas naturezas distintas. Em outras palavras a luz é uma onda com uma partícula associada a ela. A ideia de um objeto físico ser duas coisas ao mesmo não pode ser compreendida segundo os arcabouços da física clássica, por isso, retomando ideias da mecânica quântica e sintetizando as contribuições de Bruna e Beatriz (T110 e T111), o professor acaba por fornecer a explicação dessa interpretação: “[...] É uma partícula que é associada com uma onda ou uma onda com uma partícula" (T113).

Mesmo com a resposta dada pelo professor, a fala do aluno Pedro (T115) nos mostra que ainda há confusão sobre o que significa uma entidade fisica ter duas características tão paradoxais, desse modo, a dúvida ainda persiste entre os alunos. Em resposta à questão colocada por Pedro, o professor prossegue a discussão qualificando novamente a situação, uma vez que delimita novamente o contexto de investigação quando diz que "[...] Pra mecânica clássica isso [a luz ser onda e partícula] não é possivel. (T118) Mas em física moderna a gente vai ter que arrumar uma nova explicação. E essa nova explicação, então, pode ser que ela seja as duas coisas ao mesmo tempo?” (T121). Ao final desse turno, vemos que o professor reformula a dúvida colocada em discussão e a problematiza lançando de volta aos alunos. Essa ação de propor um problematizar uma determinada situação é típica da metodologia do ensino por investigação e auxilia o professor a motivar os alunos uma vez que não fornece respostas prontas aos mesmos.

A partir do turno 123, no qual vemos que o professor problematiza a interpretação da complementaridade, desencadeia-se uma extensa discussão entre os alunos que acabam por emitir diversas hipóteses para tentar explicar o significado.

\begin{tabular}{|c|c|c|c|c|}
\hline \multicolumn{5}{|c|}{ Quadro 16 - Trecho de falas da aula } \\
\hline $\mathbf{T}$ & Falas Transcritas & $\begin{array}{l}\text { Propósitos } \\
\text { Epistêmicos }\end{array}$ & $\begin{array}{l}\text { Tipo de } \\
\text { Pergunta }\end{array}$ & $\begin{array}{l}\text { Indicadores } \\
\text { de AC }\end{array}$ \\
\hline 140 & $\begin{array}{l}\text { Vitor: Tipo, microscopicamente é uma } \\
\text { partícula, macroscopicamente ela é uma onda. }\end{array}$ & & & $\begin{array}{l}\text { Levantamento } \\
\text { de hipótese }\end{array}$ \\
\hline 141 & $\begin{array}{l}\text { Professor: Ta. Segundo o Vitor, se a gente } \\
\text { olhar lá no microscópio... Microscópio não, se } \\
\text { olhar no mundo dos micro, né? Se for pensar } \\
\text { nela lá, enquanto natureza mesmo, na sua } \\
\text { formação ela é? }\end{array}$ & $\begin{array}{l}\text { Sintetizar } \\
\text { Explorar }\end{array}$ & & \\
\hline 142 & Vitor: Partícula. & & & \\
\hline 143 & $\begin{array}{l}\text { Professor: Partícula. Mas se a gente observar } \\
\text { de fora, no macroscópico, é isso? Aí ela é } \\
\text { onda. Pode ser isso? }\end{array}$ & $\begin{array}{l}\text { Sintetizar } \\
\text { Explorar }\end{array}$ & $\begin{array}{l}\text { Pergunta } \\
\text { exploratória } \\
\text { sobre o }\end{array}$ & \\
\hline
\end{tabular}




\begin{tabular}{|l|l|l|l|l|}
\hline & & & processo & \\
\hline 144 & Beatriz: Depende de como se olha & & & \\
\hline
\end{tabular}

A interpretação da complementaridade caracteriza a luz como sendo onda e partícula, mas nunca ambas ao mesmo tempo, diferentemente da interpretação dualista-realista que descreve a luz como onda e partícula simultaneamente. São nuances desse tipo que circundam o conhecimento científico e a natureza da ciência que o planejamento da SEI almejava que os alunos compreendessem. Dessa forma, vemos que no turno 140, ainda que tivesse tentando explicar o significado da interpretação da complementaridade, o aluno Vitor traz uma resposta que começa a colocar em evidência o fato de que a luz pode ser onda e partícula, mas é necessário definir um referencial para fazer tal inferência.

Tendo em vista a resposta de Vitor, o professor sintetiza e explora a ideia do aluno de forma a explicitar essas informações para os demais alunos da turma (T141 e T143). Assim, no turno 144, vemos que a aluna Beatriz compreende o ponto de vista apresentado e expressa seu posicionamento idêntico ao do colega frente a questão feita pelo professor que prossegue a discussão explorando sua contribuição.

\begin{tabular}{|c|c|c|c|c|}
\hline \multicolumn{5}{|c|}{ Quadro 17 - Trecho de falas da aula } \\
\hline$T$ & Falas Transcritas & $\begin{array}{l}\text { Propósitos } \\
\text { Epistêmicos }\end{array}$ & $\begin{array}{l}\text { Tipo de } \\
\text { Pergunta }\end{array}$ & $\begin{array}{l}\text { Indicadores } \\
\text { de AC }\end{array}$ \\
\hline 145 & $\begin{array}{l}\text { Professor: Pra } \\
\text { complementaridade? }\end{array}$ & Explorar & $\begin{array}{l}\text { Pergunta } \\
\text { exploratória } \\
\text { sobre o } \\
\text { processo }\end{array}$ & \\
\hline 146 & Beatriz: $\dot{E}$ & & & \\
\hline 147 & Vitor: Sim. & & & \\
\hline 148 & Bruna: Pra mim não é. & & & $\begin{array}{l}\text { Levantamento } \\
\text { de hipótese }\end{array}$ \\
\hline 149 & Professor: Pra você, é o que isso? & Explorar & $\begin{array}{l}\text { Pergunta } \\
\text { exploratória } \\
\text { sobre o } \\
\text { processo }\end{array}$ & \\
\hline 150 & $\begin{array}{l}\text { Bruna: Porque aí ela tá sendo duas coisas ao } \\
\text { mesmo tempo. Complementaridade é quando } \\
\text { ela tá sendo ora uma coisa ora outra. }\end{array}$ & & & $\begin{array}{l}\text { Justificativa } \\
\text { Explicação }\end{array}$ \\
\hline 151 & Vitor: Então... & & & \\
\hline 152 & $\begin{array}{l}\text { Bruna: Não. Porque o que eu to falando... No } \\
\text { micro... Olha, no mesmo momento quando } \\
\text { você analisa no micro ela é partícula e no } \\
\text { macro ela é onda. Você tá pensando no } \\
\text { mesmo momento, então na mesma coisa ela tá } \\
\text { sendo duas coisas ao mesmo tempo. Mas pra } \\
\text { ser complementar no momento " } x \text { " ela tá sendo } \\
\text { uma coisa e no momento " } y \text { " ela tá sendo } \\
\text { outra, entendeu? }\end{array}$ & & & $\begin{array}{l}\text { Justificativa } \\
\text { Raciocínio } \\
\text { lógico }\end{array}$ \\
\hline
\end{tabular}


No turno seguinte à fala de Beatriz o professor continua a explorar a visão da aluna por meio de perguntas exploratórias sobre o processo (T145) e obtém como resposta um argumento elaborado pela aluna Bruna que refuta as asserções de Vitor (T140) e Beatriz (T146) e explicita não somente seu ponto de vista, mas também um dado (D), uma garantia (W) e uma conclusão (C).

Agrupando as falas da aluna Bruna, descritas nos turnos 148, 150 e 152, é possivel organizar, de acordo com o modelo de Toulmin, um argumento conforme a o esquema da figura 5.8, no qual podemos visualizar claramente os componentes da asserção proferida em resposta as perguntas do professor.

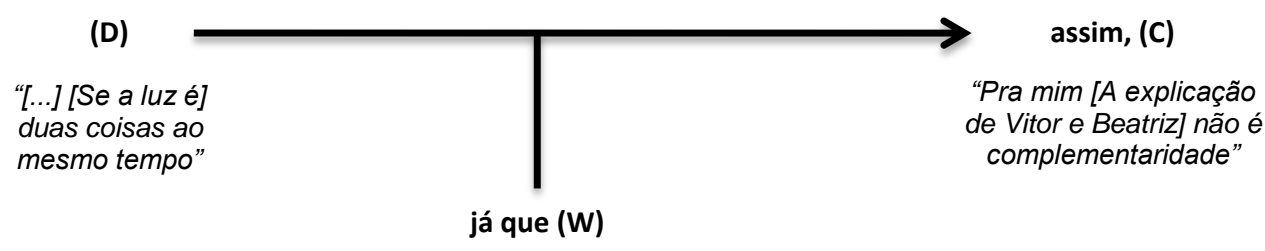

"[...] no mesmo momento quando você analisa no micro ela é partícula e no macro ela é onda. Você tá pensando no mesmo momento, então na mesma coisa ela tá sendo duas coisas ao mesmo tempo. Mas pra ser complementar no momento " $x$ " ela tá sendo uma coisa e no momento 'y' ela tá sendo outra [...]"

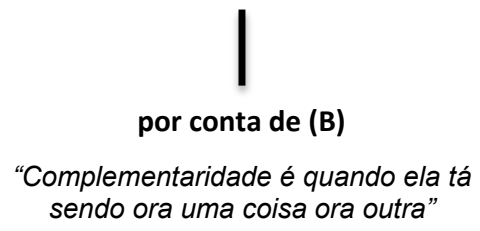

Figura 5.8 - Argumento da aluna Bruna, elaborado com base nas falas dos turnos 148, 150 e 152.

A asserção de Bruna evidencia que ela havia compreendido corretamente a interpretação da complementaridade que estava em discussão, pois além de fazer a passar dos dados à conclusão, elaborou uma garantia para justificar que se baseava nos arcabouços teóricos da teoria quântica. O professor, por sua vez, em seu papel de mediador do processo buscava essas informações nas falas dos alunos e, por isso, vemos que o propósito explorar foi o mais recorrente nos trechos acima.

Além disso, a análise da fala de Bruna feita com auxílio dos indicadores de alfabetização científica também nos mostra a forma como ela estruturou seu raciocínio: inicialmente, ela emite uma hipótese (T148), que tinha como objetivo expressar seu ponto de vista e refutar as informações que estavam sendo 
trazidas à discussão, prossegue com a elaboração de uma explicação (T150), que apresenta seu ponto de vista e traz o início de sua justificativa, esta que, por sua vez, é mais bem estruturada no turno 152, quando ela, por meio de raciocínio lógico, completa a elaboração da garantia que dá apoio à sua conclusão.

Como dito, a resposta de Bruna expressa corretamente a interpretação da complementaridade, mas, tendo em vista o objetivo do professor, típico em uma abordagem investigativa, de favorecer que os demais alunos da turma construíssem seus próprios entendimentos sobre o objeto investigado, não encontramos, nos turnos seguintes, falas do professor que pudessem ser categorizadas de acordo com o propósito epistêmico qualificar ou sintetizar como seria esperado em uma abordagem tradicional. A presença desses propósitos nas falas do professor poderia indicar que ele havia avaliado positivamente a contribuição dada, no entanto, a discussão teve continuidade com outros alunos apresentando seus pontos de vistas.

\begin{tabular}{|c|c|c|c|c|}
\hline \multicolumn{5}{|c|}{ Quadro 18 - Trecho de falas da aula } \\
\hline $\mathbf{T}$ & Falas Transcritas & $\begin{array}{l}\text { Propósitos } \\
\text { Epistêmicos }\end{array}$ & $\begin{array}{l}\text { Tipo de } \\
\text { Pergunta }\end{array}$ & $\begin{array}{c}\text { Indicadores } \\
\text { de AC }\end{array}$ \\
\hline 160 & $\begin{array}{l}\text { Aline: Eu não sei... Eu acho que é que nem ele } \\
\text { falou. Uma hora ela se comporta de uma } \\
\text { forma, como onda e outra hora como partícula. }\end{array}$ & & & $\begin{array}{l}\text { Levantamento } \\
\text { de hipótese }\end{array}$ \\
\hline 161 & $\begin{array}{l}\text { Professor: Mas aí se ela se comporta ora de } \\
\text { um jeito, ora de outro ela é o que? }\end{array}$ & Explorar & $\begin{array}{l}\text { Pergunta } \\
\text { exploratória } \\
\text { sobre o } \\
\text { processo }\end{array}$ & \\
\hline 162 & Aline: Complementaridade... & & & $\begin{array}{l}\text { Classificação } \\
\text { de informação }\end{array}$ \\
\hline 163 & $\begin{array}{l}\text { Professor: Não, ela é o que? Olha, pra primeira } \\
\text { vocês falaram assim é uma onda. Pra segunda } \\
\text { vocês falaram assim é uma partícula. Pra } \\
\text { ultima vocês tão falando que é as duas coisas } \\
\text { ao mesmo tempo. E na complementaridade ela } \\
\text { é o que? }\end{array}$ & $\begin{array}{l}\text { Sintetizar } \\
\text { Explorar }\end{array}$ & $\begin{array}{l}\text { Pergunta } \\
\text { exploratória } \\
\text { sobre o } \\
\text { processo }\end{array}$ & \\
\hline 164 & Aline: Não sei. & & & \\
\hline 165 & $\begin{array}{l}\text { Lucas: Ah... Depois de tantos experimentos pra } \\
\text { ver se é onda, onda mesmo ou se é partícula, } \\
\text { partícula mesmo... Mas o que aconteceu, } \\
\text { acabou ocorrendo fatores que defendiam } 100 \% \\
\text { que é onda enquanto que outro defendia } 100 \% \\
\text { que era partícula. Então, aí eu pensei, através } \\
\text { disso, a onda pensando num só ele recebe } \\
\text { complemento de ambas as partes. Ela não } \\
\text { pode ser definida só como onda, nem só como } \\
\text { partícula. }\end{array}$ & & & $\begin{array}{l}\text { Raciocínio } \\
\text { lógico } \\
\text { Justificativa } \\
\text { Explicação }\end{array}$ \\
\hline
\end{tabular}

A partir do turno 160, a aluna Aline apoia a conclusão de Bruna sobre a questão em discussão apresentando seu ponto de vista. O professor continua a explorar as contribuições emitidas pelos alunos por meio de perguntas exploratórias sobre o processo e, após sintetizar as informações que haviam sido 
levantadas naquele momento, o aluno Lucas (T165), apresenta seu ponto de vista baseado em informações que foram trabalhadas desde o início da aula, conforme expresso na figura 5.9, sistematizadas de acordo com o modelo de Toulmin.

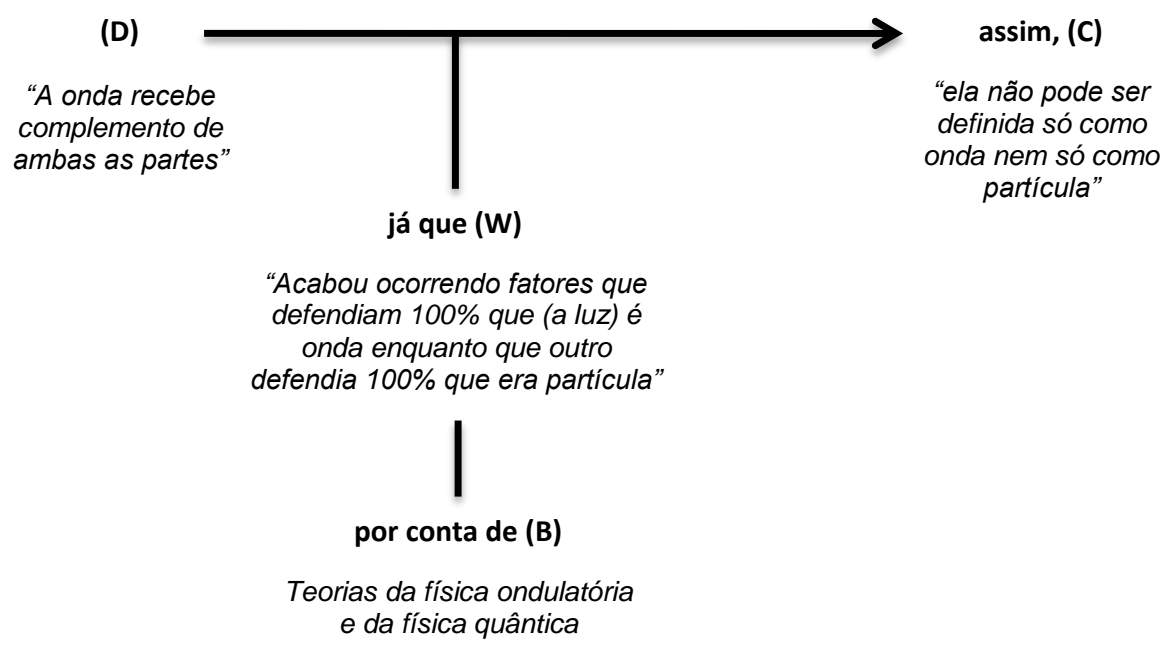

Figura 5.9 - Argumento de Lucas, elaborado com base em sua fala do turno 165.

Notemos que a asserção de Lucas possui os indicadores de alfabetização científica raciocínio lógico e previsão. O indicador raciocínio lógico mostra que o aluno se apropriou de diversas informações em caráter científico, pois evidencia relações entre dados e conclusões. Em outras palavras, em sua fala, podemos notar que ele resgatou diferentes elementos do argumento construído coletivamente no início da aula (figura 5.2 , p.93) para estrutura seu ponto de vista. Dentre os elementos desse argumento, estão em maior destaque as informações referentes à conclusão $(\mathrm{C}$ - a luz tem comportamento ondulatório e corpuscular) e aos apoios ( $\mathrm{B}_{1}$ - teoria da física ondulatória; $\mathrm{B}_{2}$ - teoria da física quântica). Assim, com base em nossa interpretação sobre esses trechos, é possivel destacar dois pontos essenciais ao desenvolvimento de uma atividade de investigação e de situações argumentativas: a construção e organização de dados, garantias e apoios; e a necessidade de o professor explorar diferentes pontos de vista sobre um mesmo objeto ou situação, pois foi por fomentar a participação dos alunos, não fornecendo respostas prontas, que possibilitou a construção de argumentos pelos alunos. 


\subsection{4.a. Síntese do episódio 4}

Como destacado na tabela 5.4, exceto pelo propósito epistêmico retomar, todos os demais puderam ser encontrados nas falas do professor proferidas ao longo deste episódio.

Do turno de fala 99 ao turno 165, que compõem esse episódio, foi possível observar que o objetivo do professor era suscitar as compreensões dos estudantes acerca das quatro principais interpretações dadas pela mecânica quântica para o comportamento dual da luz, conforme estabelecido no planejamento da atividade. Tal observação pode ser suportada pelo fato de o propósito epistêmico problematizar ter ocorrido nove vezes, ou seja, com uma frequência maior que os demais.

As interpretações ondulatória e corpuscular possuem explicações bastante objetivas o que ocasionou que os alunos não apresentassem dificuldades de compreensão sobre suas definições, principalmente por terem sido trabalhadas em aulas anteriores. Nos primeiros turnos referente a este episódio, ações vinculadas ao propósito epistêmico problematizar que foram desempenhadas pelo professor, incorreu na emissão de respostas dos alunos que se puderam ser categorizadas, segundo os indicadores de alfabetização científica, como classificação de informação (ver classificação dos turnos 105 a 110 expressos na Tabela 5.4).

Ainda que a proposição dos problemas referentes às interpretações ondulatória e corpuscular não tivesse apresentado grandes dificuldades aos alunos durante a investigação, o processo de problematização referente às demais interpretações continuou em curso.

Destacamos durante a análise detalhada do episódio que para a interpretação dualista-realista e da complementaridade, as considerações a serem feitas não eram triviais. Principalmente com relação à interpretação da complementaridade, a tentativa de se construir uma explicação a elas ocasionou uma extensa discussão.

Tendo consciência da dificuldade que os alunos teriam para construírem entendimento sobre tais interpretações e da importância de utilizarem das informações que já possuíam para emitir e elaborar conclusões acerca do objeto em investigação, era esperado encontrar nas falas do professor, principalmente, ações referentes ao propósito epistêmico explorar, que por sua vez teve setes ocorrências. 
Quadro 19 - Mapa do episódio 4: classificação dos turnos de fala de alunos e professor segundo as categorias metodológicas selecionadas.

\begin{tabular}{|c|c|c|c|c|c|c|c|c|c|c|c|c|c|c|c|c|c|c|c|c|c|c|c|c|c|c|c|c|}
\hline & Turnos & 8 웅 & $\underline{-}$ & ำ & 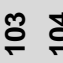 & $\stackrel{20}{\div}$ & $\stackrel{0}{\circ}$ & $\hat{o}$ & $\stackrel{\infty}{\circ}$ & & 울 & $\mp ?$ & $\stackrel{7}{7}$ & $\stackrel{\Xi}{\tau}$ & $\stackrel{\text { 농 }}{=}$ & $\stackrel{\circ}{\rightleftharpoons}$ & $\underline{F}$ & 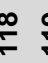 & & & $\underset{\mathfrak{N}}{\mathfrak{N}}$ & $\stackrel{\mathbb{N}}{\tau}$ & $\underset{\text { I }}{\mathbb{Z}}$ & & 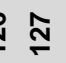 & 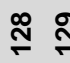 & స్ స్ \% & $\bar{m}$ \\
\hline & Sujeito & P A & $\mathbf{P}$ & A & $P A$ & $\mathbf{P}$ & A & $\mathbf{P}$ & A & $P$ & A & $A \quad$ & $A F$ & A & A & $\mathbf{P}$ & A & $\mathbf{P}$ & $A$ & $F$ & A & $\mathbf{P}$ & A & & A & A $\mathrm{P}$ & & A \\
\hline & Retomar & & & & & & & & & & & & & & & & & & & & & & & & & & & \\
\hline of & Problematizar & $x$ & & & & $\mathrm{x}$ & & $\mathrm{x}$ & & $x$ & & & & & & & & & & $x$ & & & & & & & & \\
\hline 悹 & Explorar & & & & & & & & & & & & & & & $x$ & & & & & & $\mathrm{x}$ & & & & & $x$ & \\
\hline 옴 응 & Qualificar & $x$ & $\mathrm{x}$ & & & & & & & & & & & & & & & $x$ & & & & & & & & & & \\
\hline & Sintetizar & & & & & & & & & $x$ & & & s & & & & & & & & & & & & & & & \\
\hline & de problematização & & & & & & & & & & & & & & & & & & & & & & & & & & & \\
\hline 它 & sobre dados & & & & & & & & & & & & & & & & & & & & & & & & & & & \\
\hline 은 훟 & exploratória sobre o processo & & & & & $\mathrm{x}$ & & & & & & & & & & & & & & & & $\mathrm{x}$ & & & & & & \\
\hline & sistematização & & & & & & & & & & & & & & & & & & & & & & & & & & & \\
\hline & Seriação de informação & & & & & & & & & & & & & & & & & & & & & & & & & & & \\
\hline & Organização de informação & & & & & & & & & & & & & & & & & & & & & & & & & & & \\
\hline$\stackrel{=}{n=}$ & Classificação de informação & & & & & & $\mathrm{x}$ & & $\mathrm{x}$ & & $\mathrm{x}$ & $\mathrm{x}$ & & & & & & & & & & & & & & & & \\
\hline 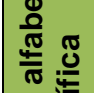 & $\begin{array}{l}\text { Levantamento de hipótese } \\
\text { Teste de hipótese }\end{array}$ & & & & & & & & & & & $x$ & $x$ & & & & & & $x$ & 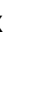 & $\mathrm{x}$ & & $\mathrm{x}$ & $x$ & & & & $\mathrm{x}$ \\
\hline 范 & Justificativa & & & & & & & & & & & & & & & & & ( & $x$ & & & & & & & & & \\
\hline 흠 & Previsão & & & & & & & & & & & & & & & & & & & & & & & & & & & \\
\hline .ֶ. & Explicação & & & & & & & & & & & & & & & & & & & & & & & & & & & \\
\hline 호 & $\begin{array}{l}\text { Raciocínio lógico } \\
\text { Raciocínio proporcional }\end{array}$ & & & & & & & & & & & & & & & & & & & & & & & & & & & \\
\hline
\end{tabular}


Quadro 19 - Mapa do episódio 3: classificação dos turnos de fala de alunos e professor segundo as categorias metodológicas selecionadas.

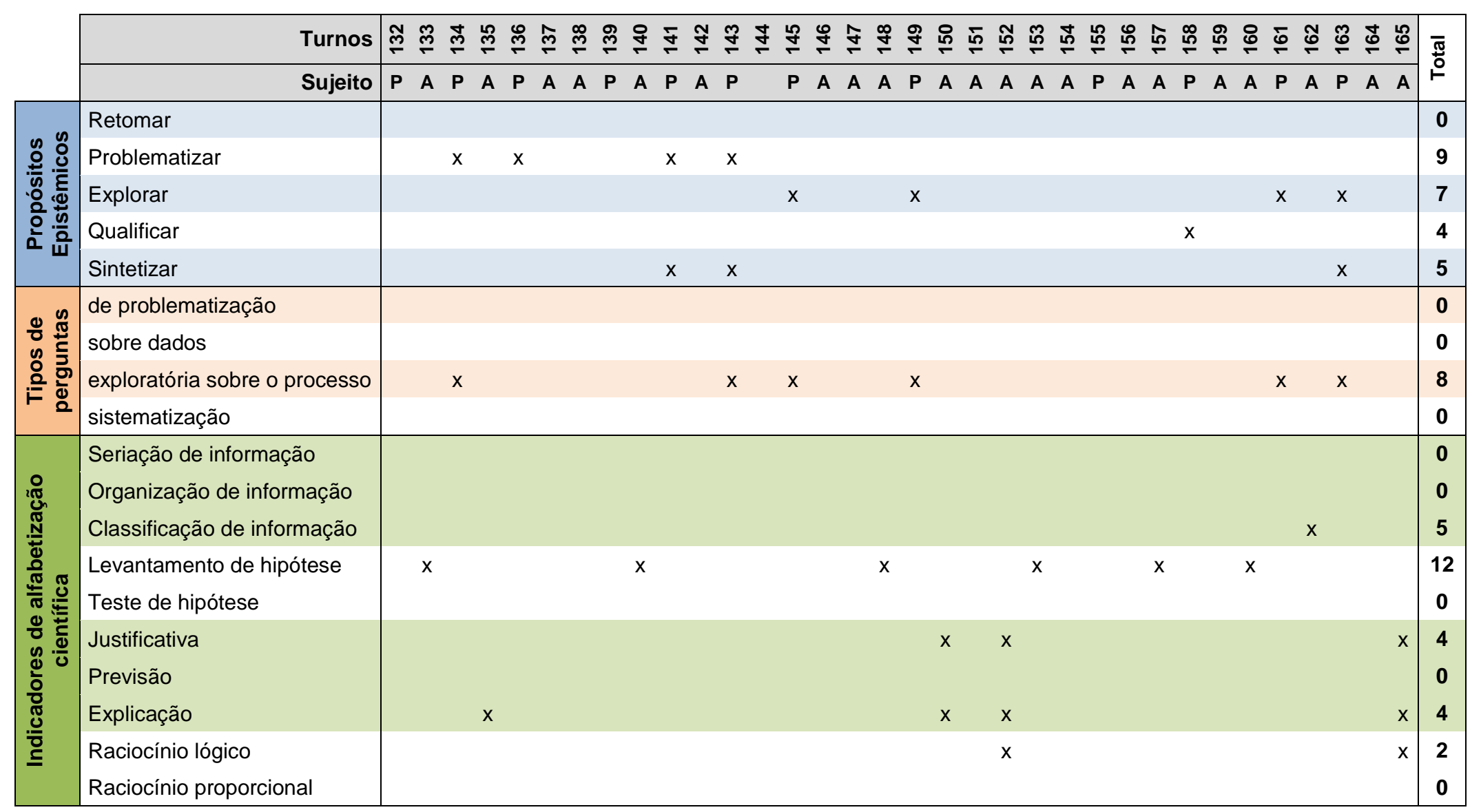


Em resposta às ações relacionadas ao propósito epistêmico explorar, é possivel notar que as falas dos alunos foram, essencialmente, levantamento de hipóteses. Ao explorar as situações em discussão e os pontos de vista apresentados, o professor favoreceu não só a participação dos alunos no processo de investigação, mas também a ocorrência de argumentos, construídos pelos alunos com base nas informações que haviam sido construídas e sistematizadas desde o processo de retomada, conforme descrito no episódio 1.

Assim como no episódio 2, a presença dos indicadores de alfabetização científica justificativa, explicação e raciocínio lógico revelaram a presença de argumentos proferidos pela aluna Bruna (turnos 148 ao 152) e pelo aluno Lucas (turno 165): foi nos turnos referentes às falas de Bruna e de Lucas que identificamos elementos do padrão de argumento de Toulmin, tais como dado, garantia e conclusão, o que corrobora com a inferência de que a ocorrência dos indicadores de alfabetização científica supracitados indicam a construção de argumentos pelos alunos. Entretanto, fazendo a leitura atenta da classificação das falas dos alunos e professor, conforme descrito na Tabela 5.4, vemos que os indicadores de alfabetização científica que marcam a construção de argumentos ocorreram após a ocorrência de classificação de informações e levantamento de hipóteses, relacionados, respectivamente, ao trabalho com dados empíricos e delimitação de variáveis.

Conforme a descrição desses indicadores de alfabetização científica feita por Sasseron (2008), estes evidenciam não só as respectivas destrezas que representam, mas também a capacidade de o aluno relacionar diferentes variáveis, a organização de informações para obtenção de conclusões e, finalmente, a apropriação de conceitos e ideias em nível epistemológico. Dessa forma, torna-se possivel perceber um panorama condizente com as expectativas teóricas do ensino por investigação que almejam do estudante, entre outros aspectos, um aprendizado ativo que valorize não só a compreensão de conceitos científicos, mas também aspectos ligados à própria natureza da ciência e do conhecimento científico.

Finalmente, a leitura da ocorrência dos propósitos epistêmicos para promoção da argumentação em comparação com a ocorrência dos tipos de perguntas feita pelo professor permitiu também inferir que as perguntas exploratórias sobre o processo possuem uma relação direta com o propósito epistêmico qualificar, uma vez todas as falas do professor que continham esse tipo de pergunta possuíam também ações relacionadas ao propósito em questão. 


\subsubsection{EPISÓDIO 5 - INTERFERÊNCIA PARA UM ÚNICO FÓTON}

Após a discussão sobre as quatro interpretações dadas pela mecânica quântica para a natureza dual da luz descrita no episódio anterior, o professor prossegue a investigação sem fazer nenhum tipo de sintese sobre o que foi apresentado pelos alunos com relação à interpretação da complementaridade.

Como dito, a explicação a essa interpretação causou uma extensa discussão e a exposição de diferentes pontos de vista. Dessa forma, diante das dúvidas e conclusões apresentadas, o professor optou, conforme disposto no planejamento da SEI, por não fornecer a resposta esperada. Essa ação pode ser compreendida como uma forma de favorecer que os estudantes emitam hipóteses e construam seus próprios entendimentos sobre a situação, além de que, estimula a participação dos mesmos no processo investigativo.

\begin{tabular}{|c|c|c|c|c|}
\hline \multicolumn{5}{|c|}{ Quadro 20 - Trecho de falas da aula } \\
\hline $\mathbf{T}$ & Falas Transcritas & $\begin{array}{l}\text { Propósitos } \\
\text { Epistêmicos }\end{array}$ & $\begin{array}{l}\text { Tipo de } \\
\text { Pergunta }\end{array}$ & $\begin{array}{l}\text { Indicadores } \\
\text { de AC }\end{array}$ \\
\hline 175 & $\begin{array}{l}\text { Professor: Vamos pra linha de baixo. Pra cada } \\
\text { uma dessas interpretações, como é que a } \\
\text { gente, como é que a gente explica a } \\
\text { experiência do interferômetro? Supondo que a } \\
\text { gente... Vamos explicar o interferômetro ideal, } \\
\text { já que nem todo mundo conseguiu ver no real. } \\
\text { Como é que a gente explica a figura? Essa } \\
\text { figura } 1 \text { que ta ali [aponta para o resultado } \\
\text { obtido por meio do IMZ virtual, conforme a fig. } \\
\text { 5.3]. Se é uma onda, como é que a gente pode } \\
\text { explicar a interferência? }\end{array}$ & $\begin{array}{l}\text { Problematizar } \\
\text { Qualificar }\end{array}$ & $\begin{array}{l}\text { Pergunta } \\
\text { exploratória } \\
\text { sobre o } \\
\text { processo }\end{array}$ & \\
\hline 176 & Bruna: Inaudível. & & & \\
\hline 177 & Professor: Fala alto. & & & \\
\hline 178 & Bruna: Inaudível. & & & \\
\hline 179 & Professor: Não entendi. & & & \\
\hline 180 & $\begin{array}{l}\text { Beatriz: Aquele negócio de ondas destrutivas e } \\
\text { construtivas. }\end{array}$ & & & Explicação \\
\hline 181 & $\begin{array}{l}\text { Professor: Ah, aquele negócio de ondas } \\
\text { construtivas e destrutivas, foi isso que você } \\
\text { falou? }\end{array}$ & Explorar & & \\
\hline 182 & Bruna: É. & & & \\
\hline 183 & $\begin{array}{l}\text { Professor: Ainda bem que tem um amplificador. } \\
\text { Tá, é assim que todo mundo acha? Eu consigo } \\
\text { explicar a interferência como sendo duas } \\
\text { ondas... Fase igual constrói, fases diferentes } \\
\text { elas se anulam, é isso? Alguém tem outra ideia } \\
\text { pra explicar isso? }\end{array}$ & $\begin{array}{l}\text { Explorar } \\
\text { Sintetizar }\end{array}$ & $\begin{array}{l}\text { Pergunta } \\
\text { exploratória } \\
\text { sobre o } \\
\text { processo }\end{array}$ & \\
\hline 184 & Alunos: Inaudível. & & & \\
\hline 185 & $\begin{array}{l}\text { Bruna: É... Pra ter interferência tem que ter } \\
\text { duas ondas. Quando elas tão na mesma fase, } \\
\text { você vai ter a interferência construtiva que vai } \\
\text { aumentar. Agora quando tá tendo... De um } \\
\text { lado você tá tendo a voltinha assim e do outro } \\
\text { ao contrário vai ser destrutiva, então vai } \\
\text { diminuir. Se forem iguais os valores vai acabar } \\
\text { com a onda. Isso se forem ondas, agora se for }\end{array}$ & & & $\begin{array}{l}\text { Explicação } \\
\text { Raciocínio } \\
\text { lógico }\end{array}$ \\
\hline
\end{tabular}




\begin{tabular}{|c|l|l|l|l|}
\hline & complementar aí eu não sei explicar. & & & \\
\hline 186 & $\begin{array}{l}\text { Professor: E como partícula? Como é que a } \\
\text { gente explica isso? Alguém que não falou } \\
\text { ainda... Felipe, Priscila, Talita, John... Como é } \\
\text { que eu explico essa interferência se for } \\
\text { partícula? }\end{array}$ & Problematizar & $\begin{array}{l}\text { Pergunta } \\
\text { exploratória } \\
\text { sobre o } \\
\text { processo }\end{array}$ & \\
\hline 187 & Felipe: Parte é onda e parte é partícula... & & $\begin{array}{l}\text { Levantamento } \\
\text { de hipótese }\end{array}$ \\
\hline 188 & $\begin{array}{l}\text { Alunos: Mas como se só tem fótons... } \\
\text { [Inaudível] }\end{array}$ & & & \\
\hline 189 & Professor: Calma, deixa o rapaz pensar. & & & \\
\hline 190 & Beatriz: A da complementaridade... & & & \\
\hline
\end{tabular}

A partir do turno 175, o professor dá início ao processo de investigação de uma questão que havia sido levantada ainda nos primeiros momentos da aula: “Como explicar a interferência para um único fóton?”.

É possivel notar que a estratégia adotada consiste em analisar o IMZ e seus resultados à luz das quatro interpretações previamente discutidas. Assim, como podemos ver no turno 175, o professor inicia sua fala utilizando dos próprios epistêmicos qualificar e problematizar, pois quando diz "pra cada uma dessas interpretações, como é que a gente [...] explica a experiência do interferômetro?", há tanto a delimitação do contexto da investigação como a proposição de um problema. Além disso, ainda qualificando a situação, o professor faz referência a um resultado obtido por meio da manipulação do IMZ virtual (figura 5.3, p.94) para solicitar explicações aos alunos.

O problema apresentado no início da fala desse turno é bastante denso e exige que se façam diversas considerações acerca das condições de investigação para se elaborar respostas adequadas. Em outras palavras, a resolução do problema exige que as asserções se baseiem em, pelo menos, uma das quatro interpretações discutidas. Sabendo disso, é possivel inferir com a leitura do final de sua fala, quando diz "se é onda, como que a gente pode explicar a interferência?”, que o professor fragmenta esse grande problema em um problema menor.

Particionar um problema ou fenômeno é uma das características que marcam o ensino por investigação, pois a depender da forma da questão inicial, a mesma pode não ser compreendida pelos alunos como algo passível de ser explicado, inviabilizando todo o processo investigativo. Dessa maneira, ao realizar essa ação, o professor favorece a participação dos alunos e permite que eles avancem em suas contribuições de forma que, conforme a discussão for se adensando, o problema se torne mais complexo para se se atingir os objetivos almejados pelo planejamento da investigação proposta. 
Em resposta a pergunta exploratória sobre o processo feita pelo professor no turno 175 com o intuito de investigar o IMZ com base na interpretação ondulatória, no turno 180 a aluna Beatriz emite uma explicação à situação. No turno 183, o professor sintetiza a contribuição de Beatriz e busca explorar outros pontos de vista sobre por meio de outra pergunta exploratória sobre o processo, até que, no turno 185, a aluna Bruna emite sua resposta categorizada com os indicadores de alfabetização científica explicação e raciocínio lógico.

Notemos que a fala de Bruna é bastante coerente com as informações que foram evidenciadas desde o início da investigação, podendo ser organizada na forma de um argumento, conforme o modelo de Toulmin representado no esquema da figura 5.10.

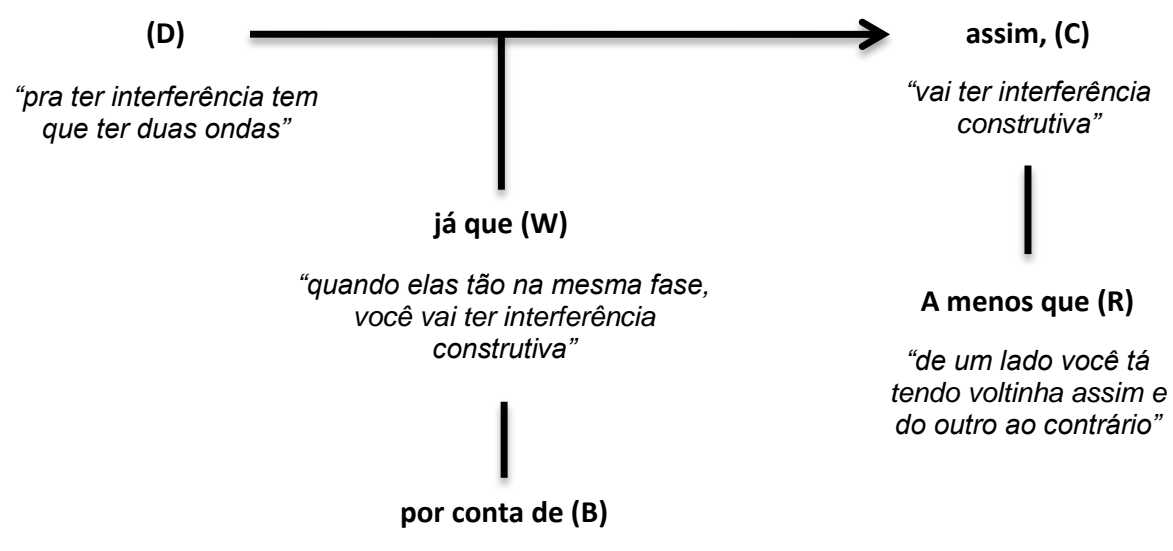

Teorias da física ondulatória

Figura 5.10 - Argumento de Bruna, referente a sua fala do turno 185.

A fala de Bruna merece ser analisada com cautela por diversas razões. Primeiramente, notemos que a garantia (W), o apoio (B) e o refutador (R) utilizados por ela são referentes às informações que foram colocadas em evidencia ainda no início da aula. Além disso, o raciocínio utilizado por ela, identificado inclusive na forma de um indicador de alfabetização científica, evidencia que ela parece ter dominado os conceitos envolvidos e necessários à compreensão do objeto de investigação, pois a sua construção explicitava seu entendimento sobre a situação de tal forma que foi apta a relacionar diferentes elementos em uma única fala.

Por fim, ainda que não seja objetivo de nossa análise, a presença de um refutador claramente identificável permite que seu argumento seja definido como 
sendo de nível 4, o segundo maior da escala proposta de Erduran et al. (2004). Como dito, ações que evidenciam e relacionam diferentes variáveis e informações deixam clara não só a destreza do aluno com relação à articulação de ideias, mas também à apropriação de conceitos, procedimentos e atitudes próprios do conhecimento científico almejados pelo ensino de ciências e que, no contexto de nossa análise, foram alcançados por meio do ensino por investigação.

Ao final da fala de Bruna, ela explicita que a dúvida sobre a questão da interpretação da complementaridade ainda era latente na discussão. O professor, conhecedor da dúvida e ciente que os alunos ainda não tinham formado bases sólidas o suficiente para construírem entendimento sobre a situação, não se prende a essa questão nesse momento e prossegue com a discussão de forma a não interromper a fluidez da investigação.

Com objetivo de estruturar os elementos necessários à construção de novas explicações, no turno 186 o professor problematiza uma nova situação experimental e pergunta aos alunos quais seriam as implicações se, ao invés de ondas, eles estivessem trabalhando com partículas. No turno 190, vemos que, assim como na fala de Bruna no turno 185, que apesar de o professor ter dado continuidade com a investigação lançando novos problemas, a dúvida sobre a interpretação da complementaridade ainda inquietava os alunos a ponto de eles expressarem isso em suas falas.

Até o fim do turno 185 são apresentados mais um problema, que compõem o problema central desse episódio: "[...] como é que eu explico essa interferência se forma partícula". Este problema almeja a explicação para o resultado do padrão de interferência encontrado por meio do IMZ, diferindo apenas por um estar associado a interpretação da complementaridade e o outro a interpretação dualista-realista.

\begin{tabular}{|c|l|l|l|l|}
\hline \multicolumn{1}{|c|}{ Quadro 21- Trecho de falas da aula } & \multicolumn{1}{c|}{$\begin{array}{c}\text { Propósitos } \\
\text { Epistêmicos }\end{array}$} & $\begin{array}{c}\text { Tipo de } \\
\text { Pergunta }\end{array}$ & $\begin{array}{c}\text { Indicadores } \\
\text { de AC }\end{array}$ \\
\hline 193 & $\begin{array}{l}\text { Professor: Fala aí Bia, o que você queria } \\
\text { explicar então da... Como é que você explica o } \\
\text { interferômetro? }\end{array}$ & Explorar & & \\
\hline 194 & Alunos: Inaudível. & & & \\
\hline 195 & Professor: Fala, Bia. & & & \\
\hline 196 & Beatriz: Ele tá falando aqui... [Inaudível] & & & \\
\hline 197 & $\begin{array}{l}\text { Professor: Não, mas como é que você explica } \\
\text { interferência? }\end{array}$ & Explorar & & \\
\hline 198 & Beatriz: Ah... & & & \\
\hline 199 & Professor: Pensando na complementaridade. & $\begin{array}{l}\text { Explorar } \\
\text { Qualificar }\end{array}$ & $\begin{array}{l}\text { Pergunta } \\
\text { exploratória } \\
\text { sobre o }\end{array}$ & \\
\hline
\end{tabular}




\begin{tabular}{|l|l|l|l|l|}
\hline & & & processo & \\
\hline 200 & Beatriz: Não sei... & & & \\
\hline 201 & Professor: Falem mais. & & & \\
\hline 202 & Alunos: Estamos tentando... & & & \\
\hline 203 & $\begin{array}{l}\text { Professor: E á? Tá bom, vamos pro último } \\
\text { então. Dualista-realista. Vocês disseram que... } \\
\text { Nossa! }\end{array}$ & & & \\
\hline
\end{tabular}

A construção de explicação sobre a interpretação da complementaridade e a sua diferenciação da interpretação dualista-realista foi um momento de grande impasse no curso da aula. Nos turnos 193, 197, 199 e 201 vemos que o professor buscou, por meio de ações relacionados ao propósito epistêmico explorar, aprofundar as ideias que os alunos estavam trazendo a discussão. Todavia, as contribuições não estavam mais avançando fazendo com que o professor prosseguisse com a investigação e dando início ao processo de sistematização da aula.

Ao longo desse episódio, a maior questão a ser solucionada tinha relação com as interpretações da complementaridade e dualista-realista. O professor, sabendo da dificuldade que os alunos poderiam encontrar para definir essas interpretações, buscou explorar de diversas maneiras as contribuições que foram trazidas a discussões de forma que argumentos fossem construídos e evidenciasse o entendimento do conteúdo que estava sendo investigado. Na fala dos alunos foi possivel encontrar os indicadores de alfabetização científica levantamento de hipótese, explicação e raciocínio lógico. Esses indicadores nos dão indícios que o processo argumentativo estava em curso, mas, mesmo assim, as contribuições que foram emitidas não possibilitou a sintese do que era esperado fazendo com que o professor prosseguisse com o planejamento da aula.

\subsection{5.a. Sintese do episódio 5}

Por meio da leitura da análise dos turnos de fala do professor referente a esse episódio (Tabela 5.5), iniciado no turno 166 e finalizado no turno 202, é possivel notar a configuração de um quadro bastante amplo no que tange aos propósitos epistêmicos encontrados. Ações desempenhadas pelo professor vinculadas ao propósito epistêmico explorar foram as mais frequentes, com total de seis ocorrências. Além disso, o propósito problematizar também esteve presente em quantidade relevante de vezes, com três ocorrências. 
Quadro 22 - Mapa do episódio 5: classificação dos turnos de fala de alunos e professor segundo as categorias metodológicas selecionadas.

\begin{tabular}{|c|c|c|c|c|c|c|c|c|c|c|c|c|c|c|c|c|c|c|c|c|c|c|c|c|c|}
\hline Turnos & $\stackrel{\div}{\circ} \div$ & ஜ & 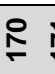 & $\frac{1}{2}$ & $\stackrel{5}{\stackrel{n}{n}}$ & 达 $\stackrel{10}{2}$ & $\stackrel{0}{\leftarrow} \hat{f}$ & $\stackrel{乛}{\leftarrow} \stackrel{\infty}{\leftarrow}$ & $\stackrel{R}{5}$ & థీ & $\bar{\Phi} \underset{\infty}{\infty} \stackrel{\infty}{\leftarrow}$ & $\stackrel{\infty}{\infty} \stackrel{\varpi}{\leftarrow}$ & $\stackrel{\leftrightarrow}{\longleftarrow}$ & $\stackrel{\mathscr{\infty}}{\leftarrow}$ & $\widehat{\infty} \stackrel{\infty}{\infty}$ & $\stackrel{\mathscr{\infty}}{\leftarrow}$ & 우 : & 호 ㅇำ & $\stackrel{\wp}{\circ}$ & Фั 용 & $\stackrel{9}{\circ}$ & 횽 ๑ & ㅇํํ & ธิ ลิ ลิ & 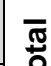 \\
\hline Sujeito & $\begin{array}{l}P \\
\end{array}$ & A & $\mathbf{P}$ & A A & A A & $A P$ & A $P$ & $P \quad A$ & $\mathbf{P}$ & A & $\mathbf{P A}$ & P A & A A & $\mathbf{P}$ & A A & $P$ & A $F$ & $\mathbf{P A}$ & $\mathbf{P}$ & A P & $A F$ & $\mathbf{P A}$ & $\mathbf{P A}$ & $A \quad P \quad A$ & $\stackrel{\circ}{\circ}$ \\
\hline Retomar & & & & & & & & & & & & & & & & & & & & & & & & & \\
\hline Problematizar & & & & & & $x$ & & & & & & & & $x$ & & & & $x$ & & & & & & & 3 \\
\hline Explorar & $x$ & & & & & & & & & & $x$ & $\mathrm{x}$ & & & & & & & $\mathrm{x}$ & & & $x$ & $\mathrm{x}$ & & 6 \\
\hline Qualificar & & & & & & $x$ & & & & & & & & & & & & & & & & & $\mathrm{x}$ & & 2 \\
\hline Sintetizar & & & & & & & & & & & & $\mathrm{x}$ & & & & & & $x$ & & & & & & & 2 \\
\hline de problematização & & & & & & & & & & & & & & & & & & & & & & & & & 0 \\
\hline sobre dados & & & & & & & & & & & & & & & & & & & & & & & & & ( \\
\hline exploratória sobre o processo & $x$ & & & & & $x$ & & & & & & $x$ & & $x$ & & & & $x$ & & & & & $x$ & & ( \\
\hline sistematização & & & & & & & & & & & & & & & & & & & & & & & & & 0 \\
\hline Seriação de informação & & & & & & & & & & & & & & & & & & & & & & & & & \\
\hline Organização de informação & & & & & & & & & & & & & & & & & & & & & & & & & \\
\hline Classificação de informação & & & & & & & & & & & & & & & & & & & & & & & & & \\
\hline Levantamento de hipótese & & & & & & & & & & & & & & & $x$ & & & & & & & & & & 1 \\
\hline Teste de hipótese & & & & & & & & & & & & & & & & & & & & & & & & & \\
\hline Justificativa & & & & & & & & & & & & & & & & & & & & & & & & & \\
\hline Previsão & & & & & & & & & & & & & & & & & & & & & & & & & \\
\hline Explicação & $x$ & & & & & & & & & $x$ & & & $x$ & & & & & & & & & & & & 3 \\
\hline $\begin{array}{l}\text { Raciocínio lógico } \\
\text { Raciocínio proporcional }\end{array}$ & & & & & & & & & & & & & $x$ & & & & & & & & & & & & \\
\hline
\end{tabular}


Mais do que contagem absoluta de ocorrências dos propósitos epistêmicos explorar e problematizar, é importante destacar que estes propósitos estavam correlacionados a perguntas distintas, mas, principalmente as perguntas exploratórias sobre o processo, uma vez que o professor sempre se baseava em situações que já haviam sido trabalhadas com os alunos, seja em outras aulas ou nos momentos iniciais da investigação.

Nessa perspectiva, é possível corroborar empiricamente com a concepção de que é imprescindivel que haja construção, organização e evidenciação prévia dos aportes necessários tanto para a elaboração de argumentos pelos alunos, como também para a proposição de problemas que sejam compreendidos como questões passiveis de investigação.

Com relação a construção de argumentos pelos alunos, um ponto que merece ser destacado deste episódio é o fato da ocorrência de um novo argumento, emitido pela aluna Bruna no turno 185. O mesmo só foi emitido após a realização de ações do professor relacionadas ao propósito epistêmico explorar e sintetizar (turnos 181 e 183). Os indicadores de alfabetização científicos que foram encontrados nas falas dos alunos em resposta a estas ações foram, essencialmente, explicação e raciocínio lógico. Disso podemos inferir que a busca pelo professor por respostas mais elaboradas dos alunos permitiu a construção de ligações lógicas entre dados e conclusões, possibilitando assim a emergência de um argumento completo segundo o padrão de Toulmin.

\subsubsection{EPISÓDIO 6 - SiSTEMATIZAÇÃO E ENCERRAMENTO}

O objetivo de nossa pesquisa era evidenciar as ações do professor promotoras de argumentação no contexto do ensino por investigação. Apesar de este episódio final conter falas que puderam ser classificadas segundo as categorias que elaboramos e utilizamos em nossa análise, o mesmo colabora pouco para a construção de conclusões sobre a nossa questão inicial que buscava caracterizar as ações promotoras de argumentação desempenhadas por um professor. Apoiado nessa justificativa, julgamos que não é relevante exibir trechos desse momento da aula, pois não nos permitiram aprofundar nossos entendimentos sobre como a argumentação dos estudantes pode ser promovida e desenvolvida. 
Quadro 23 - Mapa do episódio 6: classificação dos turnos de fala de alunos e professor segundo as categorias metodológicas selecionadas.

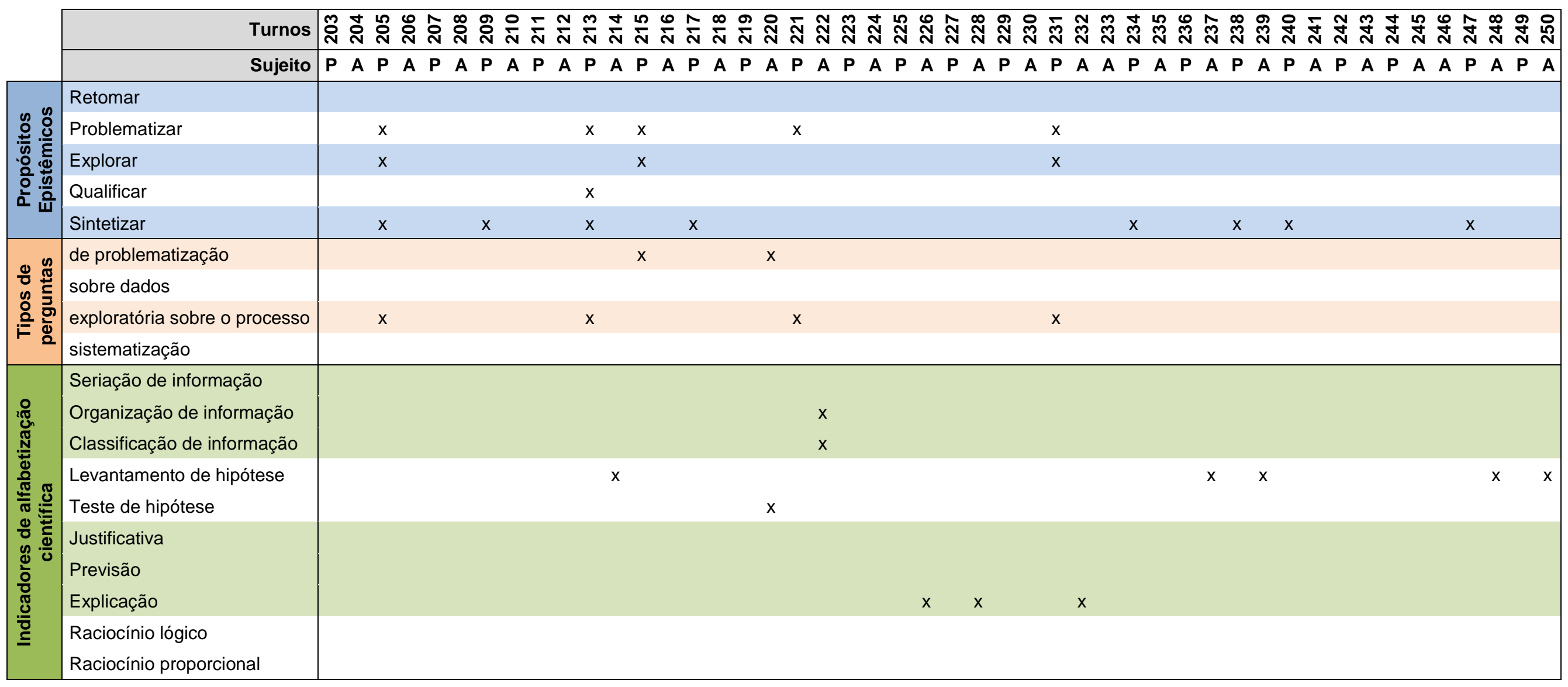


Quadro 23 - Mapa do episódio 6: classificação dos turnos de fala de alunos e professor segundo as categorias metodológicas selecionadas.

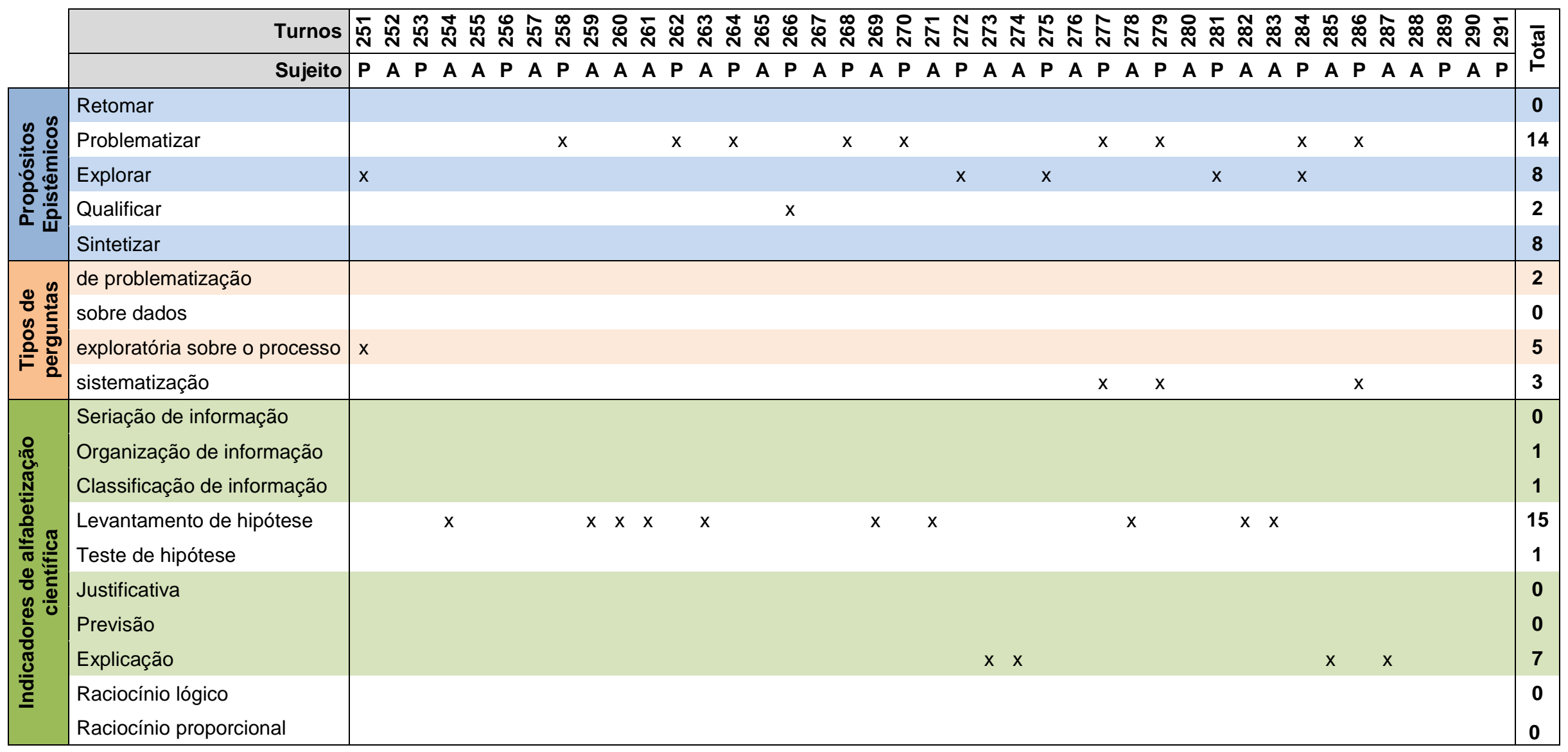


O último episódio da aula analisada consiste no momento de sistematização do conteúdo que havia sido discutido durante a investigação. Os turnos referentes a esse episódio, turno 203 ao turno 290, foram também categorizados e analisados à luz dos instrumentos metodológicos adotados (Tabela 5.6).

Neste último episódio, o professor dá início a esse processo de sistematização retomando as definições das quatro interpretações investigadas e apresentando novamente algumas das divergências entre os pontos de vista levantados pelos dos alunos ao longo da aula. Em seguida, usa da atividade de sistematização que eles tinham em mãos desde o início da aula para explicitar o objetivo da mesma e esclarecer dúvidas sobre sua elaboração.

As ações tomadas pelo professor neste episódio foram, essencialmente, relacionadas aos propósitos epistêmicos problematizar, com catorze ocorrências, sintetizar e explorar, ambos com oito ocorrências.

Resumidamente, as falas do professor consistiam em sintetizar informações e explicações que haviam sido construídas desde o início da aula, para em seguida problematizar essa situação e explorar algumas das hipóteses que eram proferidas pelos alunos. O tipo de pergunta mais recorrente foram as perguntas exploratórias sobre o processo e perguntas de sistematização e os indicadores de alfabetização científica mais encontrados nas falas dos alunos foram, essencialmente, explicação e levantamento de hipóteses.

Por meio da leitura desses resultados, acreditamos que por ser um momento de encerramento, no qual se faz necessária a organização de conclusões e, principalmente, de conceitos, apesar de o professor problematizar e explorar diferentes situações ele não deu oportunidades para os alunos desenvolverem suas respostas inviabilizando, por exemplo, que encontrássemos argumentos em suas falas. Todavia, explicações e hipóteses foram emitidas, mas não exploradas de forma extensa como feito ao longo do episódio 5. 


\section{ALGUMAS CONCLUSÕES}

No universo do ensino de ciências por meio de abordagens ancoradas nos pressupostos do ensino por investigação, muitas são as interações que podem resultar na construção de entendimento pelos estudantes sobre conteúdos científicos e características da natureza e epistemologia do trabalho científico. Portanto, é fundamental que a área de pesquisa em educação em ciências busque compreender como surgem e ocorrem essas interações e os processos de ensino e aprendizagem em um ambiente tão dinâmico que é a sala de aula.

Buscamos nesse trabalho traçar um panorama sobre como o professor, visto por nós como agente central para que a implementação de abordagens didáticas investigativas seja bem sucedida, promove o surgimento e o desenvolvimento da argumentação dos estudantes. É o professor o responsável por criar um ambiente de múltiplas interações entre os alunos, de forma que estes sejam capazes de justificar suas alegações e construírem suas explicações para as situações que investigam com base em conhecimentos que têm disponiveis.

À luz destes pressupostos, ainda no primeiro capítulo desta pesquisa, colocamos a seguinte questão: Quais ações tomadas pelo professor promovem o surgimento e desenvolvimento da argumentação pelos estudantes no contexto do ensino por investigação?

Responder a esta questão não é algo objetivo e é necessário ter cautela quanto às inúmeras variáveis que se engendram no contexto da cultura escolar e nos processos de ensino e aprendizagem. Iniciamos o desenvolvimento de nossa pesquisa buscando definir e delimitar o contexto em que a resposta à questão norteadora seria construída. Estabelecemos, então, em um primeiro momento a concepção sobre o ensino por investigação como abordagem didática. Defendemos nossa visão evidenciando a necessidade de uma proposta investigativa contemplar diferentes tipos de práticas pedagógicas e didáticas, não privilegiando um ou outro tipo de atividade. Do mesmo modo, ressaltamos o papel essencial a ser desempenhado pelo professor, tanto no processo de 
planejamento como de implementação das aulas que se baseiam nesses pressupostos.

A preocupação premente desta pesquisa era, também, a argumentação dos estudantes. Estruturamos os arcabouços teóricos que regeram o trabalho metodológico e permitiu a construção de entendimento sobre os nossos dados de origem empírica. Entretanto, ter definições precisas sobre os elementos a serem trabalhados em sala de aula não é suficiente para se construir conclusões completas sobre as diversas nuances que circundam o aprendizado dos estudantes, mas é essencial para se caracterizar especificidades do ensino e fornecer subsídios a pesquisadores e educadores para estruturarem novos planejamentos didáticos a serem considerados, principalmente, no que tange à formação, inicial e continuada, de nossos professores.

Ao compreender a necessidade de os alunos terem espaço para emitirem e elaborarem múltiplas explicações, o professor busca favorecer o surgimento de um espaço de compartilhamento de ideias e negociação de significados. Nesse sentido, vimos que durante a implementação de uma abordagem didática investigativa é um estimulada a criação de um ambiente privilegiado para o surgimento de interações de diferentes naturezas e compartilhamento de ideias, o qual foi denominado espaço interativo de argumentação colaborativa. Assim, a prática de promover interações e o compartilhamento de ideias visando a construção coletiva de entendimento pelos estudantes sobre um mesmo objeto, mais do que garantir autonomia frente aos seus avanços cognitivos, promove e valoriza também a postura coerente com os objetivos do ensino de ciências que vise à Alfabetização Científica.

O professor pode atuar de diferentes formas em uma situação de aprendizagem que vise à promoção da argumentação dos alunos e as categorias discutidas nesse trabalho buscaram caracterizar as principais dessas ações e compreender como elas ocorrem ao longo de uma atividade de investigação. Organizamos grupos de ações dentro de categorias mais amplas, denominadas propósitos epistêmicos para a promoção da argumentação e com base nos resultados obtidos com sua utilização como instrumento metodológico, traçamos um panorama de como, a partir de ações distintas desempenhadas pelo professor, os alunos foram favorecidos a desenvolverem seus pontos de vistas e apresentá-los de forma colaborativa durante o intercurso de uma atividade investigativa, culminando na construção de argumentos. 
Com base na leitura das análises de nossos dados, vimos que a contabilização da frequência absoluta de ocorrência de cada categoria não é representativa do ponto de vista de possibilitar a construção de conclusões sobre a questão inicial. Do mesmo modo, foi possível compreender que não é coerente a existência de uma ordem cronológica associada aos propósitos epistêmicos. O que podemos afirmar com base em nossas interpretações sobre os dados discutidos ao longo do capítulo 5 é que, primeiramente, os alunos não estão habituados a trabalharem em um contexto diferenciado como é o caso de um ambiente ocasionado pelo ensino por investigação. Nossos dados corroboram essa visão, pois, como vimos, frequentemente o professor teve que solicitar a participação dos alunos ao processo de investigação com a pena de, caso não agisse dessa maneira, os alunos não se "arriscarem" a apresentar seus pontos de vista sobre o objeto em estudo e, por consequência, não teriam desenvolvido suas hipóteses e explicações, estas que, por sua vez, permitiram a construção de argumentos bastante sofisticados.

Essa particularidade encontrada ao longo da análise dos nossos dados é interpretada como uma resistência oferecida pelos alunos à mudança de postura em sala de aula, pois, uma vez que passaram por vários anos escolares vivenciando um ensino tradicional, quando é proporcionado espaço para se expressarem e construírem conhecimento de maneira ativa eles não se sentem confortáveis a ponto de se posicionarem e emitirem suas contribuições. Em outras palavras, a abordagem baseada no ensino por investigação além de necessitar ultrapassar a barreira dos portões da escola e do planejamento do professor para chegar à sala de aula, deve levar em conta aspectos da cultura escolar construídos nos alunos ao longo de vários anos e que não são alterados com facilidade.

Especificamente com relação aos propósitos epistêmicos para promoção da argumentação, construído por meio da concatenação de elementos teóricos e empíricos e reestruturados diversas vezes de forma a facilitar o processo de análise e a utilização por outros pesquisadores que tenham interesses semelhantes aos nossos, concluímos que para promover a argumentação dos estudantes é necessário que o professor saiba com profundidade o conteúdo a ser investigado com os alunos. Tendo conhecimento informações, ideias e situações as quais delimitam o contexto e o objeto de investigação é que o professor pode desempenhar ações e emitir perguntas que façam com que seus alunos sintam a necessidade de adquirir um novo saber. 
Aprender ciências, assim como qualquer outra forma de conhecimento, não implica apenas no acúmulo de informações e é bem aceito que apenas uma abordagem tradicional não é eficaz do ponto de vista de proporcionar o anseio e necessidade pela descoberta de novos conteúdos. Nesse sentido, desponta-se necessário considerar que para que ocorra a construção de conhecimento pelos alunos de maneira ativa, como almejado em diversas pesquisas e documentos oficiais, só é possivel quando os conhecimentos pré-existentes não são suficientes para compreender e explicar uma determinada situação. Assim, acreditamos que o domínio do conteúdo e a construção de entendimento sobre o que seja ciências permitirá ao professor apresentar e explorar situações limites relacionadas ao problema de investigação criando nos alunos o anseio pela busca de novos conhecimentos necessários para o entendimento do que está sendo discutido. 


\section{REFERÊNCIAS BIBLIOGRÁFICAS}

ANDRADE, G. T. B. Percursos históricos de Ensinar Ciências através de atividades investigativas. Revista Ensaio, v. 13, n. 1, p. 121-138, 2011.

ANDRIESSEN, J. Arguing to learn. In: SAWYER, R. K. (Ed.) The Cambridge handbook of the learning sciences. UK: Cambridge University Press, 2006, cap. 26 , p. 443-459.

BARRELO JR., N. A argumentação no discurso oral e escrito de alunos do ensino médio em uma sequência didática de física moderna. 2010. Dissertação (mestrado) - Faculdade de Educação da Universidade de São Paulo (USP), 2010.

BERLAND, L. K.; HAMMER, D. Framing for scientific argumentation. Journal of Research in Science Teaching, v. 49, n. 1, p. 68-94, 2012.

BERLAND, L. K.; REISER, B. J. Making sense of argumentation and explanation. Science Education, v. 93, n. 26, p. 26-55, 2009.

BORGES, A. T. Novos rumos para o laboratório escolar de ciências. Caderno Brasileiro de Ensino de Física, v. 19, n. 3, p. 291-313, 2002.

BRASIL. Ministério da Educação. Parâmetros Curriculares Nacionais: Ensino Médio. Brasília: MEC, SEMTEC, 1999.

BRASIL. Ministério da Educação. PCN+ Ensino Médio: Orientações educacionais. Ciências da Natureza, Matemática e suas tecnologias. Brasília: MEC, SEMTEC, 2002.

BRASIL. Ministério da Educação. Diretrizes Curriculares Nacionais gerais da Educação Básica. Brasília: MEC, SEB, DICEI, 2013.

BRICKER, L. A.; BELL, P. Conceptualizations of argumentation from science studies and the learning sciences and their implications for the practices of science education. Science Education, v. 92, n. 3, p. 473-498, 2008.

BROCKINGTON, G. A realidade escondida: A dualidade onda-particula para estudantes do ensino médio. 2005. Dissertação (mestrado) - Instituto de Física e Faculdade de Educação da Universidade de São Paulo (USP), 2005. 
CARVALHO, A. M. P. Ensino e aprendizagem de ciências: Referenciais teóricos e dados empíricos das sequências de ensino investigativas (SEI). In: LONGHINI, M. D. (Org.) O Uno e o Diverso. Uberlândia: EDUFU, 2011a, cap. 18, p. 253-266

CARVALHO, A. M. P. Uma metodologia de pesquisa para estudar os processos de ensino e aprendizagem em salas de aula. In: SANTOS, F. M. T. e GRECA, I. M. (Orgs.) A pesquisa em ensino de ciências no Brasil e suas metodologias. 2. ed. Ijuí: Editora Unijuí, 2011b, p. 13-47.

CARVAlHO, A. M. P. O ensino de ciências e a proposição de sequências de ensino investigativas. In: CARVALHO, A. M. P. (Org.) Ensino de Ciências por investigação: Condições para implementação em sala de aula. São Paulo: Cengage Learning, 2013, cap. 1, p. 1-20.

De CHIARO, S.; LEITÃO, S. O papel do professor na construção discursiva da argumentação em sala de aula. Psicologia: Reflexão e Crítica, v. 18, n. 3, p. 350-357, 2005.

DUSCHL, R. A.; SCHWEINGRUBER, H. A.; SHOUSE, A. W. (Eds). Taking science to school: Learning and teaching science in grades $\mathrm{K}-8$. Washington, DC: National Academy Press, 2007.

ERDURAN, S. Methodological foundations in the study of argumentation in sceince classroom. In: ERDURAN, S.; JIMÉNEZ-ALEIXANDRE, M. P. (Eds.) Argumentation in science education: Perspectives from classroom-based research. Springer, 2008, cap 3, p. 47-69.

ERDURAN, S.; SIMON, S.; OSBORNE, J. TAPping into argumentation: Developments in the application of Toulmin's argument pattern for studying science discourse. Science Education, v. 88, n. 6, p. 915-933, 2004.

ERICKSON, F. Qualitative Research methods for science education. In: FRASER, B. J.; TOBIN, K. G. (Eds.) International Handbook of Science Education. Great Britain: Kluwer Academic Publishers, 1998, cap. 10, p. 1155-1173.

FERRAZ, A. T.; SASSERON, L. H. Ações do professor para promover argumentação em aulas investigativas. Encontro de Pesquisa em Ensino de Física, 14., 2012, Maresias, São Paulo. Resumos...

FERRAZ, A.T.; SASSERON, L. H. Dualidade Argumentativa: os produtos da argumentação em aulas investigativas. Encontro Nacional de Pesquisa em Educação em Ciências, 9., 2013, Águas de Lindóia, São Paulo. Resumos...

FERRAZ, A. T.; SOLINO, A. P.; SASSERON, L.H. Cultura científica escolar: o que significa fazer ciência na escola? In: Encontro de Pesquisa em Ensino de Física, 15., 2014, Maresias/São Paulo. Resumos...

FLICK, L. B.; LERDERMAN, N. G. (Eds.) Scientific inquiry and nature of science. Netherlands: Springer, 2006. 
GOUW, A. M. S.; FRANZOLIN, F.; FEJES, M. E. Desafios enfrentados por professores na implementação de atividades investigativas nas aulas de ciências. Ciência e Educação, v. 19, n. 2, p. 439-454, 2013.

JIMÉNEZ-ALEIXANDRE, M. P. 10 ideas clave: Competencias en argumentación y uso de pruebas. Espanha: Graó, 2010.

JIMÉNEZ-ALEIXANDRE, M. P.; RODRÍGUEZ, A. B.; DUSCHL, R. A. "Doing the Lesson" or "Doing Science": Argument in high school genetics. Science Education. v. 84, n. \#, p. 757-792, 2000.

JIMÉNEZ-ALEIXANDRE, M. P.; ERDURAN, S. Argumentation in science education: An overview. In: ERDURAN, S.; JIMÉNEZ-ALEIXANDRE, M. P. (Eds.) Argumentation in Science education: Perspectives from classroom-based research. Springer, 2008, cap 1, p. 03-27.

KERLIN, S. C.; McDONALD, S. P.; KELLY, G. J. Complexity of secondary scientific data sources and students' argumentative discourse. International Journal of Science Education, v. 32, n. 9, p. 1207-1225, 2010.

KRASILCHIK, M. Reformas e Realidade: O caso do ensino de ciências. São Paulo em Perspectiva, n. 14, v. 1, p. 85-93, 2000.

KRAJCIK, J.; McNEILL, K. L. Designing instructional materials to support students in writing scientific explanations: Using evidence and reasoning across the middle school years. Paper presented at the annual meeting of the National Association for Research in Science Teaching, Garden Grove, CA, 2009.

LEDERMAN, N. G. Syntax of nature of Science within inquiry and Science instruction. In: FLICK, L. B.; LERDEMAN, N. G. (Eds.) Scientific Inquiry and Nature of Science: Implications for teaching, learning, and teaching education. Netherlands: Springer, 2006, cap. 14, p. 301-317.

LEITÃO, S. Processos de construção do conhecimento: A argumentação em foco. Pro-Posições, v. 18, n. 54, p. 75-92, 2007.

LEITÃO, S. O lugar da argumentação na construção do conhecimento em sala de aula. In: LEITÃO, S.; DAMIANOVIC, M. C. (Orgs.) Argumentação na escola: O conhecimento em construção. São Paulo: Pontes Editores, 2011, cap. 1, p. 13-46.

LEMKE, J. L. Aprender a hablar ciencia: Lenguage, aprendizaje y valores. Barcelona: Paidós, 1997.

LIDAR, M.; LUNDQVIST, E.; ÖSTMAN, L. Teaching and learning in the Science classroom: The interplay between teachers' epistemological moves and students' practical epistemology. Science Education, v. 90, n. 1, p. 148-163, 2006. 
LORENZETTI, L.; DELIZOICOV, D. Alfabetização científica no contexto das séries iniciais. Ensaio - Pesquisa em Educação em Ciências, v. 3, n. 1, p. 37-50, 2001.

MACHADO, V. F. A importância da pergunta na promoção da alfabetização cientifica dos alunos em aulas investigativas de Física. 2012. \# f. Dissertação (mestrado) - Instituto de Física e Faculdade de Educação da Universidade de São Paulo (USP), 2012.

MINNER, D. D.; LEVY, A. J.; CENTURY, J. Inquiry-Based science instruction What is it and does it matter? Results from a research synthesis years 1984 to 2002. Journal of Research in Science Teaching, v. 47, n. 4, p. 474-496, 2010.

McNEILL, K. L. Elementary students' views of explanation, argumentation, and evidence, and their abilities to construct arguments over the school year. Journal of Research in Science Teaching, v. 48, n. 7, p. 793-823, 2011.

McNEILL, K. L.; LIZOTE, D. J.; KRAJCIK, J.; MARX, R. W. Supporting student's construction of scientific explanation by fading scaffolds in instructional material. The Journal of the Learning Sciences, v. 15, n. 2, p. 153-191, 2006.

MORTIMER, E. F.; SCOTT, P. Atividade dirscursiva nas salas de aula de ciências: Uma ferramenta sociocultural para analisar e planejar o ensino. Investigações em Ensino de Ciências, v. 7, n. 3, p. 283-306, 2002.

MUNFORD, D.; LIMA, M. E. C. C. Ensinar ciências por investigação: Em quê estamos de acordo? Revista Ensaio, v. 9, n. 1, p. 72-89, 2007.

NASCIMENTO, S. S.; VIEIRA, R. D. Contribuições e limites do padrão de argumento de Toulmin aplicado em situações argumentativas de sala de aula de ciências. Revista Brasileira de Pesquisa em Educação em Ciências, v. 8, n. 2, 2008.

NRC, NATIONAL RESEARCH COUNCIL. Inquiry and the National Science Standards: A guide for teaching and learning. New York, National Academy Press, 2000.

OSBORNE, J. F.; PATTERSON, A. Scientific Argument and Explanation: A Necessary Distinction? Science Education, v. 95, n. 4, p. 627-638, 2011.

PESSOA JR, O. Conceitos de física quântica. São Paulo: Livraria da Física, 2003.

PIMENTEL, D. S.; McNEILL, K. L. Conducting talk in secondary science classrooms: Investigating instructional moves and teachers' beliefs. Science Education, v. 97, n. 3, p. 367-394, 2013.

RICARDO, E. C. Problematização e contextualização no ensino de física. In: CARVAlho, A. M. P. (Coord.) Ensino de Física - Coleção Ideias em Ação. São Paulo: Cengage Learning, 2010, cap. 2, p. 29-51. 
ROBERTS, D. A. Scientific literacy/Science literacy. In: ABELL, S. K.; LEDERMAN, N. G. (Eds.) Handbook of research on science education, 2007, cap. 25, p.729-780.

RUIZ-PRIMO, M. A.; LI, M.; TSAI, S-P.; SCHNEIDER, J. Testing one premise of scientific inquiry in Science classrooms: Examining students' scientific explanations and student learning. Journal of Research in Science Teaching, v. 47 , n. 5, p. 583-608, 2010.

SÁ, E. F.; LIMA, M. E C. C.; AGUIAR JUNIOR, O. A construção de sentidos para o termo ensino por investigação no contexto de um curso de formação. Investigações em Ensino de Ciências, v. 16, n. 1, p. 79-102, 2011.

SASSERON, L. H., Alfabetização Cientifica no Ensino Fundamental: Estrutura e Indicadores deste processo em sala de aula. 2008, 265p. Tese (Doutorado) - Faculdade de Educação, Universidade de São Paulo, São Paulo, 2008.

SASSERON, L. H.; CARVALHO, A. M. P. Construindo argumentação na sala de aula: A presença do ciclo argumentativo, os indicadores de alfabetização científica e o padrão de Toulmin. Ciência \& Educação, v. 17, n. 1, p. 97-114, 2011a.

SASSERON, L. H.; CARVALHO, A. M. P. Uma análise de referenciais teóricos sobre a estrutura do argumento para estudos de argumentação no ensino de ciências. Ensaio Pesquisa em Educação, v. 13, n. 3, p. 243-262, 2011 b.

SCHWARZ, B. B. Argumentation and learning. In: MIRZA, N. M.; PERRETCLERMONT, A.-N. (Eds.) Argumentation and education: Theoretical foundations and practices. Springer, 2009, p. 91-126.

SIMON, S.; ERDURAN, S.; OSBORNE, J. Learning to teach argumentation: research and development in the science classroom. International Journal of Science Education, v. 28, n. 3, p. 235-260, 2006.

SOLINO, A. P.; FERRAZ, A. T.; SASSERON, L.H. Ensino por investigação como abordagem didática: Desenvolvimento de práticas científicas escolares. In: Simpósio Nacional de Ensino de Física, 21., 2015. Uberlândia/MG. Caderno de resumos...

STAKE, R. E. Pesquisa qualitativa: Estudando como as coisas funcionam. Porto Alegre: Penso, 2011.

STRAUSS, A.; CORBIN, J. Pesquisa qualitativa: Técnicas e procedimentos para o desenvolvimento da teoria fundamentada. $2^{\text {a }}$ Ed., Porto Alegre: Artmed, 2008.

TOULMin, S. E. Os usos do argumento. São Paulo: Martins Fontes, 2. Ed., 2006. 
VIGOTSKI, L. S. Pensamento e linguagem. São Paulo: Martins Fontes, 4. Ed, 2004

ZÔMPERO, A. F.; LABURÚ, C. E. Atividades investigativas no ensino de ciências: Aspectos históricos e diferentes abordagens. Ensaio - Pesquisa em Educação em Ciências, v. 13, n. 3, p. 67-80, 2011. 
ANEXOS 


\section{ANEXo A - SEQUENCIA DE ENSINO INVESTIGATIVA ADAPTADA}

Do real clássico ao ideal quântico: Uma sequência de aulas para introduzir o tema dualidade onda-partícula no ensino médio

*SEI elaborada por Barrelo Jr (2010), com base na proposta de Brockington (2005).

Tema: Dualidade onda-partícula da Luz

Público-alvo: $3^{\circ}$ ano do Ensino Médio

Número de aulas: 11 aulas

Objetivos gerais: A sequência se inicia com uma revisão das noções básicas de óptica clássica e de diferentes modelos para a luz (raio luminoso, modelo corpuscular e ondulatório).

Síntese da sequência: Após construir e ajustar o interferômetro de Mach-Zehnder (MZ); discutimos o comportamento da luz no interferômetro e seguimos explorando o interferômetro como experimento de pensamento com fótons únicos. Visamos assim estudar a dualidade onda-partícula, o princípio da complementaridade e a noção de superposição de estados quânticos contemplando a dimensão epistemológica do conhecimento físico.

\section{OBJETIVOS ESPECÍFICOS}

1. Incentivar o aluno a refletir sobre:

a. A natureza do fenômeno quântico considerando-o a partir de uma abordagem relacional, ou seja, partindo de diferentes pontos de vista: do objeto observado, do instrumento de medida e do papel observador.

b. As implicações filosóficas da física quântica para o desenvolvimento do conhecimento físico.

c. O conhecimento físico e tecnológico como construção humana e a noção de realidade.

2. Desenvolver no aluno competências que deverão manifestar-se em suas habilidades para racionar matematicamente (formal), empregar conceitos adequadamente (conceitual) e observar e descrever objetivamente fenômenos físicos (fenomenológica).

3. Estimular o aluno a pensar e a argumentar criticamente desenvolvendo sua capacidade de trabalhar em grupo, socializar seu conhecimento, contrapor opiniões diferentes e expressar-se de maneira clara e direta.

\section{CONTEÚDO FÍSICO}

- Conceitos de óptica geométrica: reflexão, refração, transmissão e propagação da luz

- Modelos para o comportamento da luz: raio, corpuscular e ondulatório

- Funcionamento do interferômetro

- Dualidade onda-partícula

- Interpretações de mecânica quântica

\section{METODOLOGIA}

- Abordagem baseada nas concepções de Ensino por Investigação 
- Aulas expositivas e demonstrações experimentais (realizadas pelo professor)

- Simulações computacionais de experimentos (realizadas pelos alunos)

- Atividades experimentais (realizadas em grupos de alunos)

- Discussões e investigações coletivas em sala de aula

- Uso de textos de apoio e de vídeos e DVDs educacionais.

\section{DESCRICÃO AULA A AULA}

\section{Aula 1 - 0 universo físico \\ Objetivos - Levantar concepções dos alunos sobre as seguintes questões (realizadas por meio de um questionário a ser respondido em classe). \\ $\checkmark$ Como você explicaria o que é "física" para alguém que nunca estudou física? \\ $\checkmark$ O que é física quântica para você? \\ $\checkmark$ Você gostaria de aprender algo sobre física quântica? O quê? Por quê? \\ - Discutir e refletir sobre o tema "a natureza do conhecimento físico". \\ Conteúdos - O universo físico (o que existe no universo? O que existe no universo físico? Qual a diferença entre esses dois universos?). \\ - Trabalhar conceito de trajetória e caracterizar os "objetos tipo partícula" contrapondo-os aos "objetos tipo onda". \\ - A natureza do conhecimento físico (como a física "funciona"? Qual o papel da observação, dos modelos, das leis gerais, da matemática, das representações gráficas, etc.?)}

Materiais e - Apresentação da sequência didática (apresentação data-show: conhecimento Recursos físico).

- Questionário.

- Material para atividade do tatuzinho (tatuzinhos, tubos de mangueira transparente, réguas, papel milimetrado, cronômetro, etc.).

Dinâmica - Apresentação da proposta de aulas para os alunos: professor apresenta em da aula linhas gerais os objetivos e o conteúdo das aulas da sequência de aulas.

- O professor apresenta o esquema do vetor epistemológico (apresentação datashow) discutindo brevemente o processo de construção do conhecimento científico e relacionando essa discussão com a construção do fenômeno quântico que será estudado ao longo dos quatro episódios epistemológicos.

- Os alunos respondem o questionário proposto pelo professor.

- O professor propõe a atividade do tatuzinho, fornecendo as instruções e o material necessário para a realização da mesma.

- Os alunos trabalham em grupos na atividade do tatuzinho.

- O professor propõe e estimula uma discussão sobre a natureza do conhecimento físico baseado na atividade do tatuzinho de modo a levantar as concepções dos alunos sobre o que é relevante/irrelevante para o estudo do comportamento do tatuzinho do ponto de vista da física (ex. relevante: perceber a relação entre a distância percorrida e o tempo; irrelevante: considerar o estado emocional do tatuzinho).

- O professor sistematiza as ideias dos alunos sobre o que pertence ao universo e ao universo físico sistematizando a discussão sobre o conhecimento físico a exemplo da atividade do tatuzinho (ex. discute com os alunos o que essa atividade poderia significar para um biólogo, um físico, um psicólogo, um 
trabalhador rural, uma pessoa que não frequentou a escola etc.).

\begin{tabular}{|c|c|}
\hline \multicolumn{2}{|r|}{ Aula 2 - O nascimento da Física Quântica } \\
\hline Objetivos & $\begin{array}{l}\text { - Contextualizar o nascimento da física quântica (problema prático ligado a } \\
\text { questão da radiação do corpo negro e da necessidade de adaptação da teoria } \\
\text { aos dados experimentais). }\end{array}$ \\
\hline Conteúdos & $\begin{array}{l}\text { - História da física antes de } 1900 \text { (modelo ondulatório bem estabelecido). } \\
\text { - História da física por volta de } 1900 \text { (problema: determinar a melhor fonte de luz } \\
\text { para iluminar as cidades europeias: iluminação a gás ou iluminação elétrica } \\
\text { recém-descoberta; necessidade de comprar fontes luminosas diferentes: corpo } \\
\text { negro como fonte de luz ideal, quantização da radiação por Planck: } \\
\text { nascimento da física quântica). }\end{array}$ \\
\hline
\end{tabular}
Materiais e - Apresentação data-show (o nascimento da física quântica).
Recursos - Textos de apoio para os alunos.
- Fontes luminosas diferentes (lampião de gás e luz elétrica comum).
Dinâmica - O professor apresenta em linhas gerais o modelo corpuscular de Newton e o da aula modelo ondulatório salientando que esses dois modelos são contraditórios.

- O professor chama a atenção para o fato de que no final do século XIX, período que antecede o nascimento da mecânica quântica, o modelo ondulatório era o modelo aceito pela comunidade científica.

- O professor mostra as duas fontes luminosas (gás e eletricidade) e pede para que os alunos as comparem e determinem qual é que mais ilumina, qual consome mais energia, etc. (o professor salienta a dificuldade de uma avaliação subjetiva e a necessidade de realizar medidas mais precisas para comparar diferentes fontes luminosas).

- O professor apresenta e contextualiza o momento histórico de nascimento da mecânica quântica (problema prático era comparar duas fontes de luz diferentes e daí a necessidade de se utilizar uma fonte padrão de comparação, a fundação do instituto de física do reino em Berlim, as medidas dos espectros etc.).

\section{Bloco Temático: Trabalhando com os componentes ópticos do interferômetro de Mach-Zehnder}

Informações gerais sobre o bloco: No primeiro episódio temático o tema central das aulas baseia-se na observação do comportamento de um feixe luminoso emitido por uma fonte laser ao interagir com espelhos planos, semiespelhos, lentes e anteparos opacos (componentes ópticos básicos para a construção de um interferômetro de Mach-Zehnder clássico).

Nesse bloco os alunos devem "experimentar" com objetos reais e concretos (espelhos, semiespelhos etc.) paralelamente com objetos de pensamento (modelos propostos para explicar o comportamento da luz como, por exemplo, o raio luminoso, o modelo corpuscular de Newton e o modelo ondulatório) e, assim, perceberem a diferença entre essas classes de objetos.

\section{Aula 3 - Características da Luz}

Objetivos - Os alunos devem observar o comportamento do feixe luminoso ao se propagar no espaço e serem capazes de perceber que: a luz se propaga em linha reta, o feixe de laser sofre uma dispersão pequena ao longo de seu percurso até atingir um anteparo opaco e que, ao atingir o anteparo, o raio luminoso produz 
uma mancha clara praticamente homogênea sobre o mesmo.

- Os alunos devem observar o comportamento da luz ao interagir com o espelho e serem capazes de perceber e expressar oralmente (de forma qualitativa) a lei da reflexão: o ângulo de incidência é igual o ângulo de reflexão.

- Os alunos devem observar o comportamento da luz ao interagir com o semiespelho e serem capazes de perceber e expressar oralmente o fato de que o feixe luminoso ao interagir com o semiespelho é dividido em dois feixes de intensidades aproximadamente iguais sendo que: o feixe que atravessa o semiespelho (feixe transmitido) sofre um desvio na sua direção de propagação e abandona o semiespelho numa direção de propagação paralela à da incidência inicial e o feixe refletido obedece a lei da reflexão.

- Os alunos devem utilizar o modelo de raio luminoso para esquematizar em um desenho o comportamento da luz ao interagir com o espelho e com 0 semiespelho.

- Os alunos devem ser capazes de diferenciar feixe e raio luminoso (feixe: algo real ligado a nossa percepção sensorial e raio: objeto construído mentalmente, sem dimensão).

Conteúdos - Reflexão, refração, transmissão e propagação do feixe de luz.

- Conceitos de feixe e raio luminoso.

- Materiais e recursos:

Materiais e Recursos

- Componentes ópticos necessários para a construção de um interferômetro de Mach-Zehnder (fonte de laser, dois espelhos planos, dois semiespelhos, dois anteparos opacos).

- Talco ou pó de giz para refletir o feixe de laser.

* Dica para o professor: As atividades propostas no presente episódio temático devem, se possível, ser realizadas em uma sala escura;

Dinâmica da aula

1. O professor propõe que os alunos realizem em grupos de aproximadamente 5 componentes:
- Projetar o feixe de laser sobre o espelho variando o ângulo de incidência.

OBS: para visualizar a trajetória do feixe pode-se espalhar um pouco de talco ou pó de giz na região.

- Observar o comportamento do feixe refletido buscando estabelecer uma relação entre o ângulo de incidência e o ângulo de reflexão.

- Desenhar numa folha de papel o que foi observado.

- Repetir o procedimento descrito anteriormente utilizando um semiespelho (iniciar com ângulo de incidência de aproximadamente 45) buscando estabelecer uma relação entre o feixe incidente e os feixes transmitidos e refletidos.

2. O professor faz as seguintes demonstrações em sala de aula (ou propõe que os alunos as realizem em grupos):

- Projetar o feixe de laser sobre um anteparo opaco colocado a aproximadamente $5 \mathrm{~m}$ da fonte.

- Comparar o diâmetro do feixe próximo a fonte com o diâmetro do feixe sobre o anteparo.

OBS: o laser não deve apresentar uma dispersão grande.

- Desenhar o que foi observado. 
OBS: A intenção é que os alunos percebam que a noção de feixe se diferencia da noção de raio. Numa experiência de pensamento podemos reduzir a espessura do feixe de modo a obter um feixe tão estreito, que somente pode existir como uma construção geométrica. Esse não seria mais um feixe, mas sim um raio! A ideia é chamar a atenção dos alunos para o processo de modelagem do feixe transformando-o em raio e então estender essa discussão para o espelho, o semiespelho, os anteparos etc. O que é um espelho ideal? (não tem dimensão, não há perda de energia etc.).

\footnotetext{
Aula 4 - Modelo corpuscular de Newton X Modelo Ondulatório

Objetivos - Os alunos devem conhecer diferentes modelos para a luz: raio, o modelo corpuscular e o modelo ondulatório.

- Os alunos devem reconhecer as diferenças entre os modelos e perceber as limitações e os domínios de aplicação de cada modelo.

Conteúdos - Modelo corpuscular de Newton.

- Modelo ondulatório.
}

Materiais e OBS: os alunos devem trazer como tarefa realizada extraclasse uma pequena Recursos pesquisa sobre o tema: modelo corpuscular e modelo ondulatório.

- Laser e um anteparo com duas fendas (experimento simples de dupla fenda).

- Uma lata de tinta spray e um anteparo com duas fendas (analogia ao experimento de dupla fenda)

Dinâmica - O professor retoma os resultados da aula anterior solicitando que os alunos da aula consultem as anotações que fizeram quando observaram o comportamento da luz no espelho, no semiespelho e no anteparo opaco e consultem também a pesquisa que realizaram em casa.

- O professor divide a classe em dois grupos: "grupo onda" e "grupo partícula" e promove um debate entre os dois grupos propondo que: o grupo ondas tente explicar os fenômenos observados na aula anterior com o modelo ondulatório e o grupo partícula com o modelo corpuscular.

OBS: é essencial que os alunos tenham feito anteriormente em casa uma pesquisa sobre o modelo ondulatório e o modelo corpuscular.

- O professor sistematiza as discussões na lousa e mostra que o modelo corpuscular (de Newton) apresenta limitações para explicar o fenômeno de refração e de interferência.

- O professor mostra o comportamento das partículas de tinta no experimento análogo de dupla fenda realizado com tinta spray e contrapõe esse ao experimento de dupla fenda com laser (aparecimento de um padrão de interferência) salientando que o fenômeno de interferência não pode ser explicado com o modelo corpuscular.

OBS: como alternativa ao experimento com o spray pode-se utilizar também um tabuleiro de Galton com duas fendas.

\section{Bloco temático: Montando e ajustando o interferômetro de Mach-Zehnder}

Informações gerais sobre o bloco: No segundo episódio temático o conteúdo central das aulas é a montagem, ajuste e observação do interferômetro de Mach-Zehnder. Neste bloco de aulas os alunos devem perceber que as observações em física são imediatas. Fazemos hipóteses a priori. 
Aula 5 e 6 - Observando o Interferômetro de Mach-Zehnder clássico e real

$\begin{array}{lll}\text { Objetivos } & - \text { Montar o interferômetro de Mach-Zehnder. } \\ & \text { - Observar os padrões de interferência (complementares). } \\ \text { Conteúdos } & - \text { Adquirir habilidade experimental (ajuste no interferômetro). } \\ & & \text { O interferômetro de Mach-Zehnder (trabalhar dois grupos: MZ real clássico e } \\ \text { simulação do MZ) }\end{array}$
Materiais e - Apresentação (nascimento do interferômetro de MZ).
Recursos - KIT interferômetro de Mach-Zehnder real clássico.
- Simulação do interferômetro de MZ (software da universidade de Munique).
Dinâmica - O professor apresenta brevemente o interferômetro de MZ e conta um pouco da aula de sua história e de origem (a partir de um arranjo experimental do interferômetro de Jamin).

- O professor divide a classe em dois grupos: um grupo vai trabalhar com o interferômetro real clássico e o outro com o interferômetro virtual (no laboratório de informática).

- Para o grupo que vai trabalhar com o interferômetro real clássico:

- O professor apresenta o interferômetro de MZ real clássico e salienta a formação de padrões de interferência complementares chamando a atenção para a validade do modelo ondulatório como modelo adequado para explicar o comportamento da luz.

- O professor desmonta o interferômetro e propõe que os alunos em grupo montem e ajustem o aparelho de modo a obterem padrões de interferência semelhantes aos observados anteriormente.

- O professor pede que os alunos desenhem o esquema do interferômetro numa folha de papel e proponham uma explicação para o aparecimento de interferência baseada no modelo ondulatório.

- Para o grupo que vai trabalhar com o interferômetro virtual:

- Simulação do interferômetro (software livre).

\section{Bloco temático: Transformando o interferômetro de Mach-Zehnder real clássico em um interferômetro ideal}

\section{Aula 7 - Modelando o Interferômetro de Mach-Zehnder}

\begin{tabular}{|c|c|}
\hline Objetivos & $\begin{array}{l}\text { - Os alunos devem ser capazes de perceber e listar os fatores que devem ser } \\
\text { desconsiderados e os que precisam ser considerados no processo de } \\
\text { modelagem do interferômetro de MZ (transformação do interferômetro real } \\
\text { clássico em um interferômetro ideal). }\end{array}$ \\
\hline Conteúdos & $\begin{array}{l}\text { - } \text { Modelagem do interferômetro de MZ } \\
\text { - Laser }\end{array}$ \\
\hline $\begin{array}{l}\text { Materiais e } \\
\text { Recursos }\end{array}$ & $\begin{array}{l}\text { - } \quad \mathrm{KIT} \text { interferômetro de MZ real clássico. } \\
\text { - } \quad \text { Apresentação data-show (esquema do interferômetro de MZ ideal clássico). }\end{array}$ \\
\hline
\end{tabular}


- Guia para relatório.

Dinâmica - O professor apresenta novamente o interferômetro real e o interferômetro da aula esquematizado e propõe uma discussão entre os alunos visando levantar suas argumentações sobre o processo de modelagem do interferômetro (o que é espelho, semi-espelho ideal, o que significa que o interferômetro está ajustado, a necessidade de uma fonte laser, etc.).

- Os alunos trabalham em grupos completando o guia para o relatório.

\begin{tabular}{ll} 
Objetivos & $\begin{array}{l}\text { Aula } 8 \text { - A matemática do interferômetro de Mach-Zehnder } \\
\text { - Os alunos devem compreender o funcionamento do interferômetro de MZ e do } \\
\text { modelo ondulatório para a luz a partir de uma modelagem matemática do } \\
\text { fenômeno }\end{array}$ \\
\hline $\begin{array}{l}\text { Conteúdos } \\
\text { Materiais e }\end{array}$ & - Modelagem matemática do interferômetro de Mach-Zehnder \\
Recursos & - Apresentação data-show (como funciona o interferômetro de MZ). \\
Dinâmica & - O O professo de trabalho (como funciona o interferômetro de MZ). \\
da aula & - Os alunos trabalham em grupos completando a folha de trabalho.
\end{tabular}

\section{Bloco temático: Transformando o interferômetro de Mach-Zehnder clássico em um interferômetro quântico}

\begin{tabular}{|c|c|}
\hline \multicolumn{2}{|r|}{ Aula 9 - Construindo um interferômetro quântico } \\
\hline Objetivos & $\begin{array}{l}\text { - Os alunos devem ser capazes de perceber e listar os fatores que devem ser } \\
\text { desconsiderados e os que precisam ser considerados no processo de } \\
\text { transformação do interferômetro ideal clássico em um interferômetro ideal } \\
\text { quântico (exemplificando: o feixe luminoso deve ser tênue o suficiente para que } \\
\text { somente um único fóton de cada vez percorra o interferômetro, os anteparos } \\
\text { devem ser substituídos por detectores sensíveis o suficiente para registrar o } \\
\text { fóton, etc.). }\end{array}$ \\
\hline Conteúdos & $\begin{array}{l}\text { - Interferômetro de MZ quântico. } \\
\text { - } \quad \text { Dualidade onda-partícula. }\end{array}$ \\
\hline $\begin{array}{l}\text { Materiais e } \\
\text { Recursos }\end{array}$ & $\begin{array}{l}\text { - Apresentação data-show (como funciona o interferômetro de MZ quântico). } \\
\text { - Roteiro de trabalho (como funciona o interferômetro de } M Z \text { quântico). }\end{array}$ \\
\hline $\begin{array}{l}\text { Dinâmica } \\
\text { da aula }\end{array}$ & $\begin{array}{l}\text { - O professor retoma o esquema do interferômetro de MZ ideal clássico e discute } \\
\text { com os alunos a transformação do interferômetro clássico em interferômetro } \\
\text { quântico. } \\
\text { - O professor incentiva os alunos a perceberem o comportamento "estranho" do } \\
\text { fóton e a problemática da dualidade onda-partícula. } \\
\text { - Os alunos trabalham em grupos completando o roteiro de trabalho. }\end{array}$ \\
\hline & Aula 10 - Interpretações da Mecânica Quântica \\
\hline Objetivos & $\begin{array}{l}\text { - Os alunos devem conhecer quatro interpretações para o comportamento do } \\
\text { fóton no interferômetro de MZ. }\end{array}$ \\
\hline & - Os alunos devem perceber que nenhuma das quatro interpretações explica o \\
\hline
\end{tabular}


comportamento do fóton de forma completamente satisfatória.

- Os alunos devem reconhecer que, embora não exista uma interpretação completamente satisfatória para o comportamento dual dos objetos quânticos, a teoria quântica é a teoria física mais bem-sucedida desenvolvida até hoje pelos físicos e que essa teoria não só fornece previsões experimentais corretas como também possui aplicações práticas.

Conteúdos

Materiais e

Recursos

Dinâmica da aula
- Interpretações para o comportamento do fóton no interferômetro de $\mathrm{MZ}$ (interpretação corpuscular, ondulatória, dualista-realista, complementaridade).

- Apresentação data-show.

- O professor apresenta as diferentes interpretações.

- O professor promove um debate entre os alunos. Os alunos trabalham em grupos e cada grupo deve defender uma das quatro interpretações apresentadas.

- $\quad$ O professor sistematiza a aula, salientando que nenhuma das interpretações é totalmente satisfatória para explicar completamente o comportamento do fóton no interferômetro.

\footnotetext{
Aula 11 - O sentido das coisas

Objetivos - Discutir a natureza da ciência e da realidade física (nova visão de mundo da física quântica).

Conteúdos - Natureza da ciência e noção de realidade na física

Materiais e - Questionário da sequência proposta por Brockington (2005) (ver anexo B)

Recursos

Dinâmica - O professor promove o debate, iniciando a discussão a partir das hipóteses dos da aula alunos a respeito do que observaram na sala.

- O professor sistematiza a sequência de aulas, retomando a discussão da primeira aula (o universo físico).
} 


\section{ANEXo B - ATIVIdAde de SISTEMATIZAÇÃo dA AULA 10}

\section{QUESTÕES}

1) Preencha o quadro sistematizando as quatro interpretações para a natureza da luz.

\begin{tabular}{|c|c|c|c|c|}
\cline { 2 - 5 } \multicolumn{1}{c|}{} & Ondulatória & Corpuscular & Complementaridade & Dualista-Realista \\
\hline A luz é... & & & & \\
\hline $\begin{array}{c}\text { Explicação da } \\
\text { experiência do } \\
\text { Interferômetro }\end{array}$ & & & & \\
\hline $\begin{array}{c}\text { Explicação para um } \\
\text { fóton }\end{array}$ & & & & \\
\hline
\end{tabular}

2) Por que você acha que existem tantas interpretações diferentes para a natureza da luz?

3) Como você associa esse experimento com a atividade da pessoa escondida pelo lençol?

4) A partir do que viu aqui, como você acha que é a natureza da luz? Qual das quatro interpretações mais o agrada? Por quê?

5) De acordo com a interpretação da complementaridade, pode-se pensar o seguinte: Se um átomo existe somente quando olhamos para ele, o meu corpo é feito de átomo, será que meu pé existe quando não estou olhando para ele? 


\section{ANEXO C - TRANSCRIÇÃO E CLASSIFICAÇÃo DA AULA ANALISADA}

(a) Figuras utilizadas pelo professor durante a investigação
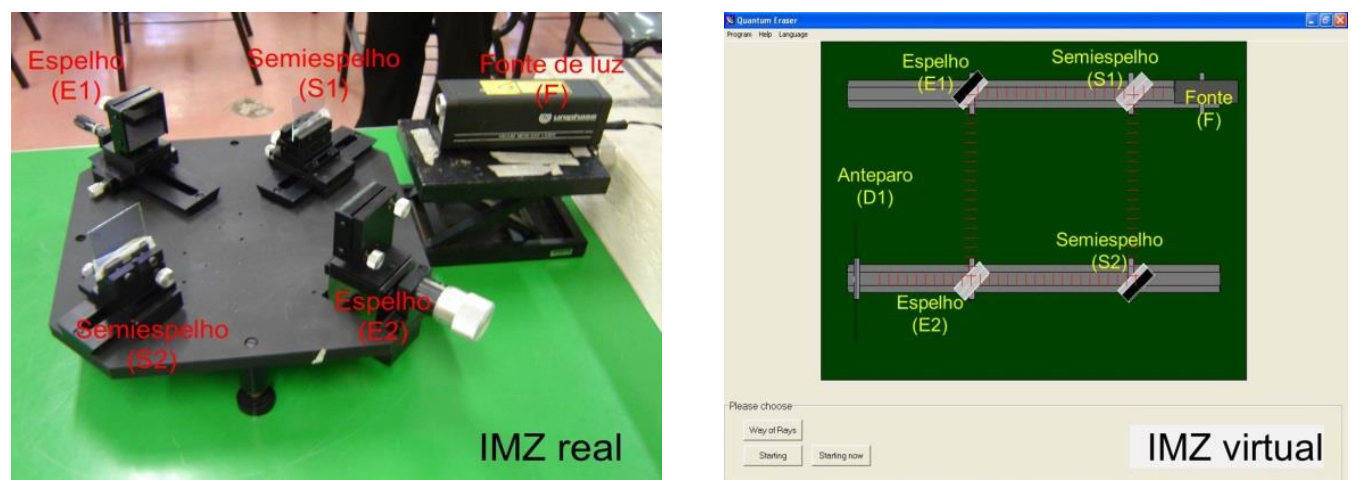

Figura 1 - a) Interferômetro de Mach-Zehnder real e b) Imagem do software de simulação.

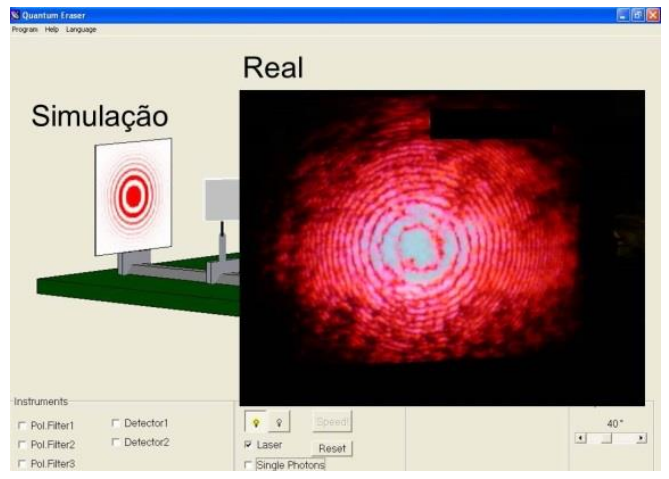

Figura 2 - Imagens de resultados típicos obtidos por meio do IMZ real e virtual. (Barrelo Jr, 2010)
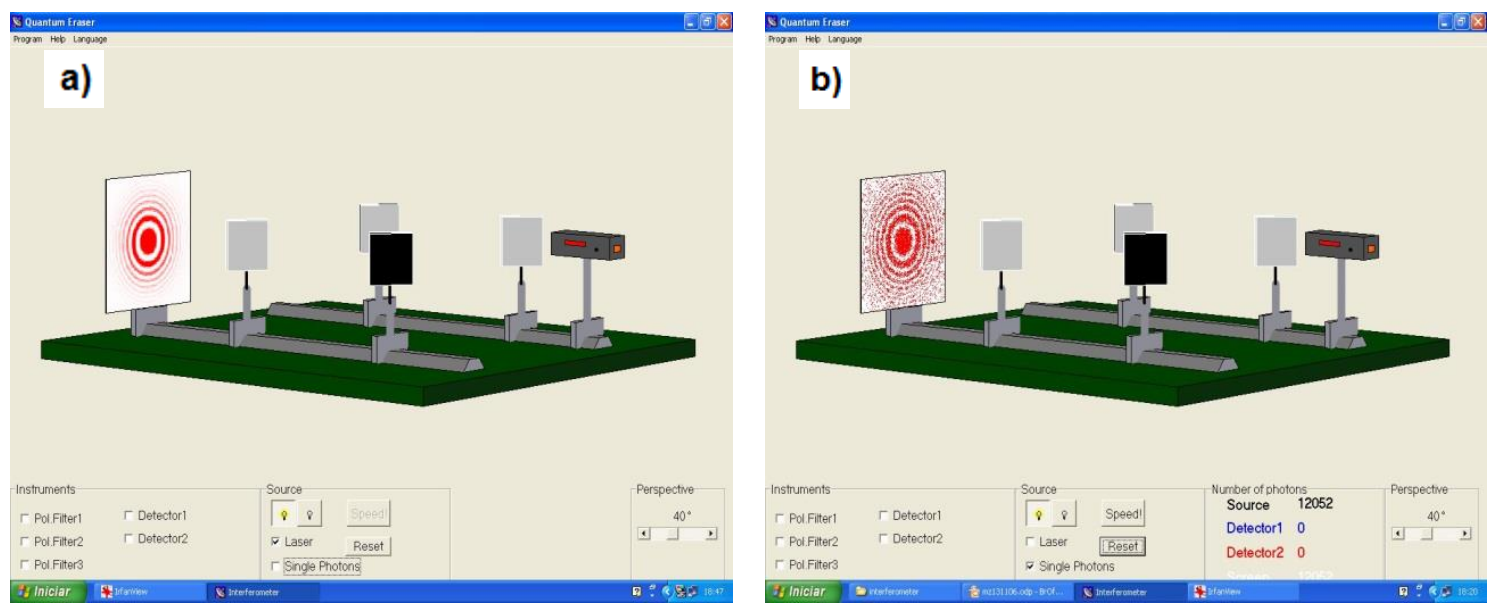
Figura 3 - Imagens utilizadas pelo professor para discutir resultados obtidos pelo IMZ considerando diferentes variáveis. Resultado obtido para a) luz enquanto ondas e b) como partícula.
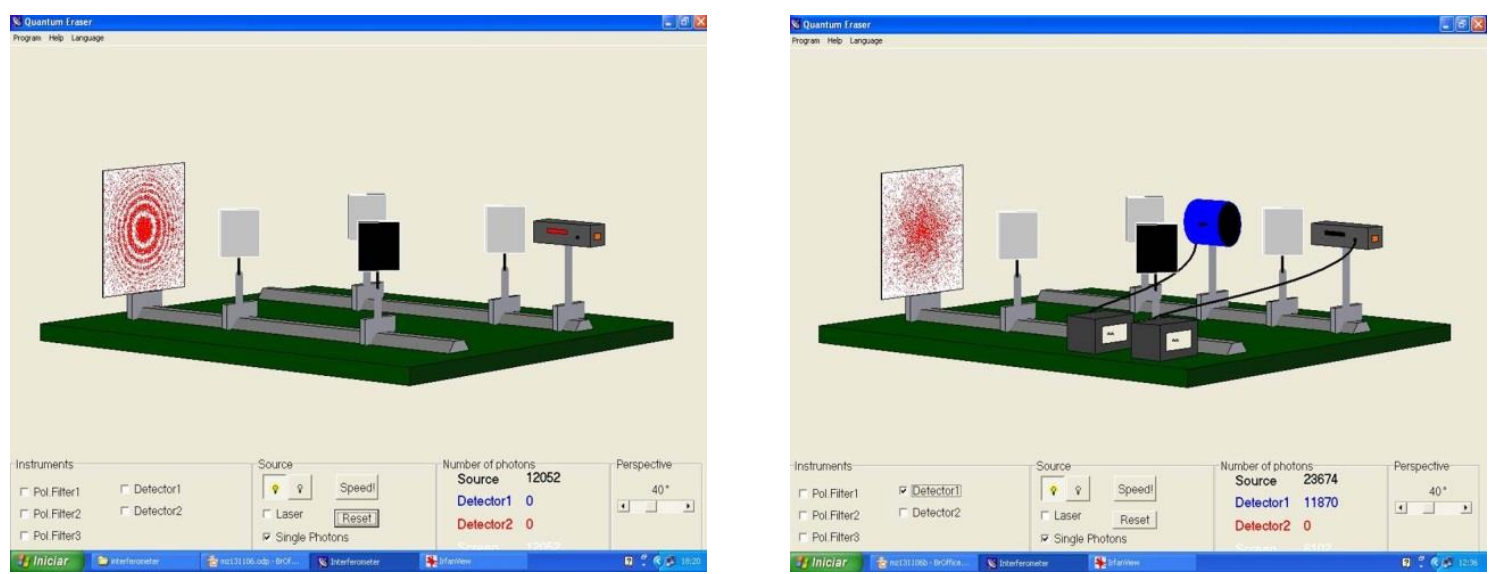

Figura 4 - Imagens utilizadas pelo professor para discutir resultados obtidos pelo IMZ considerando diferentes variáveis (\# turno 55 em diante).

\section{(b) Transcrição integral das falas ocorridas na aula 10}

\begin{tabular}{|c|c|c|c|c|}
\hline $\mathbf{T}$ & Falas Transcritas & $\begin{array}{c}\text { Propósitos } \\
\text { Epistêmicos }\end{array}$ & $\begin{array}{l}\text { Tipo de } \\
\text { Pergunta }\end{array}$ & $\begin{array}{c}\text { Indicadores } \\
\text { de AC }\end{array}$ \\
\hline 01 & Lucas: Professor. & & & \\
\hline 02 & $\begin{array}{l}\text { Professor: Mais alguém não me entregou } \\
\text { ainda a atividade da última aula? Bom } \\
\text { pessoal, presta atenção. Vocês tão recebendo } \\
\text { uma folhinha e a gente vai agora tentar } \\
\text { sintetizar as discussões que a fez ao longo do } \\
\text { ano e tentar interpretar um pouquinho o que ta } \\
\text { acontecendo de fato, ta? Pra isso a gente vai } \\
\text { continuar explorando o nosso interferômetro, } \\
\text { certo? Pra isso nós vamos combinar o } \\
\text { seguinte, nós vamos tentar fazer dessa forma, } \\
\text { vocês viram que eu tirei aí do campinho, não é } \\
\text { avaliação, ta certo? Não é prova, nem nada, é } \\
\text { apenas um questionário que a gente vai tentar } \\
\text { então sintetizar as ideias. A gente vai tentar } \\
\text { fazer da seguinte maneira, a gente vai } \\
\text { começar a discutir e a medida que a discussão } \\
\text { for avançando, eu vou dando um tempinho pra } \\
\text { que vocês respondam, preencham o quadro, } \\
\text { ta? E aí no finalzinho da aula as três últimas } \\
\text { questões, ta legal? Se não tiver dando certo } \\
\text { isso, a gente faz toda a discussão e depois a } \\
\text { gente completa a atividade. Não é pra copiar o } \\
\text { que ta... O que vai aparecer no quadro, porque } \\
\text { se não, não faz sentido. A gente vai conversar } \\
\text { sobre e depois eu tiro da tela e a gente } \\
\text { conversa, ta? Bom, na aula passada, nessa } \\
\text { aula de hoje a gente começou a discutir um } \\
\text { pouquinho o que a gente viu no interferômetro } \\
\text { real e o que a gente viu na simulação. A gente } \\
\text { vai explorar um pouquinho mais esse nosso } \\
\text { interferômetro. Á́ eu separei um pouquinho } \\
\text { algumas imagens do nosso interferômetro [faz }\end{array}$ & & & \\
\hline
\end{tabular}




\begin{tabular}{|c|c|c|c|c|}
\hline $\mathbf{T}$ & Falas Transcritas & $\begin{array}{l}\text { Propósitos } \\
\text { Epistêmicos }\end{array}$ & $\begin{array}{l}\text { Tipo de } \\
\text { Pergunta }\end{array}$ & $\begin{array}{l}\text { Indicadores } \\
\text { de AC }\end{array}$ \\
\hline & $\begin{array}{l}\text { referência a apresentação PowerPoint } ®] \text { ]. } \\
\text { Então, já ta identificado. Então, os } \\
\text { semiespelho [aponta para a imagem do IMZ, } \\
\text { fig. 1], que na verdade são vidros, né? A gente } \\
\text { pode imaginar o semiespelho como sendo } \\
\text { quando a gente olha pela janela ao entardecer } \\
\text { ou então quando a gente olha pela manhã a } \\
\text { gente, às vezes a gente enxerga nosso reflexo } \\
\text { no espelho, mas também a gente enxerga o } \\
\text { que ta lá do outro lado, ta? Tudo bem? Então, } \\
\text { os dois semiespelhos e os dois espelhos. Foi } \\
\text { esse o arranjo que a gente tem. Agora tem aí } \\
\text { a imagem do que a gente... Ta bom, se fechar } \\
\text { tudo fica muito escuro e a gente não consegue } \\
\text { ver. Bom, aí eu separei então duas imagens, } \\
\text { uma do interferômetro real e a outra do } \\
\text { simulador [aponta para a imagem projetada, } \\
\text { ver fig. 2], certo? Foi isso que a gente } \\
\text { observou, certo? Foi isso que você viu, Bia? }\end{array}$ & Retomar & $\begin{array}{l}\text { Pergunta sobre } \\
\text { dados }\end{array}$ & \\
\hline 03 & Beatriz: Não. & & & \\
\hline 04 & $\begin{array}{l}\text { Professor: Alguém enxergou uma figura } \\
\text { parecida com essa do real? }\end{array}$ & Retomar & $\begin{array}{l}\text { Pergunta sobre } \\
\text { dados }\end{array}$ & \\
\hline 05 & Priscila: Não. & & & \\
\hline 06 & Professor: Ninguém? & Retomar & & \\
\hline 07 & Alunos: Não. & & & \\
\hline 08 & $\begin{array}{l}\text { Professor: Nem naquela outra experiência que } \\
\text { a gente usou só um laser e um tecido como } \\
\text { rede de difração? }\end{array}$ & Retomar & $\begin{array}{l}\text { Pergunta sobre } \\
\text { dados }\end{array}$ & \\
\hline 09 & Aline: Sim. Eu. & & & \\
\hline 10 & $\begin{array}{l}\text { Professor: Que a gente projetou lá na parede } \\
\text { ou no quadro? }\end{array}$ & Retomar & & \\
\hline 11 & $\begin{array}{l}\text { André: Era assim, desse jeito. [mostra a mão } \\
\text { indicando forma de círculos de diferentes } \\
\text { tamanhos com os dedos, indicador e polegar } \\
\text { direito] }\end{array}$ & & & $\begin{array}{l}\text { Seriação de } \\
\text { informações }\end{array}$ \\
\hline 12 & $\begin{array}{l}\text { Professor: Era assim que tava? Ah, tirei. Não, } \\
\text { é que eu ia apresentar pra vocês tinha uma } \\
\text { outra imagem. Fala, André. }\end{array}$ & & & \\
\hline 13 & $\begin{array}{l}\text { André: Era tipo... Um monte. Um monte não, } \\
\text { não sei... }\end{array}$ & & & $\begin{array}{l}\text { Organização } \\
\text { de } \\
\text { informações }\end{array}$ \\
\hline 14 & Professor: Uma do lado da outra, não é isso? & Qualificar & & \\
\hline 15 & André: É. & & & \\
\hline 16 & $\begin{array}{l}\text { Professor: É que eu tirei a foto daqui agora, ta } \\
\text { no outro computador. A outra possibilidade, } \\
\text { tinha uma outra foto, ao invés da gente } \\
\text { enxergar dessa forma, a gente enxergava } \\
\text { mais ou menos isso aqui [aponta para uma } \\
\text { imagem semelhante ao resultado obtido pela } \\
\text { simulação, fig. 2], como disse o André. } \\
\text { Também a gente tinha essa observação... } \\
\text { Bom, aí lá na nossa experiência, pedi pra que } \\
\text { vocês identificassem. Era essa identificação } \\
\text { que a gente tinha. E foi pedido pra vocês } \\
\text { desenharem aí como é que era o caminho que } \\
\text { tava sendo percorrido pela luz [dentro do IMZ]. } \\
\text { E aí a simulação mostrava pra vocês como } \\
\text { duas frentes de onda, certo? Aí a pergunta } \\
\text { feita, não tá no textinho, não tá no roteiro, a } \\
\text { gente colocou um anteparo aqui [aponta para } \\
\text { um ponto entre o espelho E1 e o semiespelho } \\
\text { S2, ver fig. 1], certo? Se a gente colocasse o } \\
\text { anteparo aqui, deste outro lado [aponta para } \\
\text { um ponto entre o espelho E2 e o semiespelho }\end{array}$ & $\begin{array}{l}\text { Sintetizar } \\
\text { Retomar }\end{array}$ & Pergunta sobre & \\
\hline
\end{tabular}




\begin{tabular}{|c|c|c|c|c|}
\hline $\mathbf{T}$ & Falas Transcritas & $\begin{array}{l}\text { Propósitos } \\
\text { Epistêmicos }\end{array}$ & $\begin{array}{l}\text { Tipo de } \\
\text { Pergunta }\end{array}$ & $\begin{array}{l}\text { Indicadores } \\
\text { de AC }\end{array}$ \\
\hline & $\begin{array}{l}\text { S2, ver fig. 1], o que a gente deveria ver? Qual } \\
\text { a relação com essas duas figuras? }\end{array}$ & & dados & \\
\hline 17 & Bruna: Complementar & & & $\begin{array}{l}\text { Classificação } \\
\text { de } \\
\text { informações }\end{array}$ \\
\hline 18 & Professor: Como assim? & Explorar & & \\
\hline 19 & $\begin{array}{l}\text { Bruna: Por exemplo, seria assim, numa o } \\
\text { centro seria claro e teria as listras e na outra é } \\
\text { ao contrário, o centro preto e as listras ao } \\
\text { contrário. }\end{array}$ & & & $\begin{array}{l}\text { Levantamento } \\
\text { de hipóteses }\end{array}$ \\
\hline 20 & $\begin{array}{l}\text { Professor: Como que é, Vitor? Fala alto pra } \\
\text { classe ouvir. }\end{array}$ & & & \\
\hline 21 & $\begin{array}{l}\text { Vitor: Se a gente colocasse o anteparo aqui } \\
\text { [aponta para um ponto entre o espelho E2 e o } \\
\text { semiespelho S2, ver fig. 1] e não aqui [aponta } \\
\text { para um ponto entre o espelho E1 e o } \\
\text { semiespelho S2, ver fig. 1], seria o inverso do } \\
\text { que a gente viu. }\end{array}$ & & & $\begin{array}{l}\text { Levantamento } \\
\text { de hipóteses }\end{array}$ \\
\hline 22 & Alunos: Como assim? [inaudível] & & & \\
\hline 23 & Vitor: Seria o inverso do que a gente viu. & & & \\
\hline 24 & $\begin{array}{l}\text { Professor: Todo mundo acha que é isso? Todo } \\
\text { mundo acha que é a mesma coisa? E alguém } \\
\text { sabe explicar por quê? Então olha, vamos } \\
\text { imaginar... O que vocês tão me dizendo é isso, } \\
\text { num anteparo a gente observa alguma coisa } \\
\text { parecida com isso [mostra uma imagem } \\
\text { semelhante a interferência da fig. 2], certo? No } \\
\text { outro, a gente vai enxergar o contrário, não é } \\
\text { isso? Elas seriam complementares porque se } \\
\text { a gente juntasse as figuras, veria o quê? }\end{array}$ & $\begin{array}{l}\text { Explorar } \\
\text { Sintetizar } \\
\text { Explorar }\end{array}$ & $\begin{array}{l}\text { Pergunta sobre } \\
\text { dados }\end{array}$ & \\
\hline 25 & Pedro: Unm círculo & & & $\begin{array}{l}\text { Levantamento } \\
\text { de hipóteses }\end{array}$ \\
\hline 26 & $\begin{array}{l}\text { Professor: É isso. Ao invés de ver várias } \\
\text { figuras, veria um círculo. Aí, agora a } \\
\text { pergunta... Ronaldo! Alguém consegue me } \\
\text { explicar porque isso? [inaudível] Mas por quê? } \\
\text { Dá pra explicar por quê }\end{array}$ & $\begin{array}{l}\text { Qualificar } \\
\text { Sintetizar } \\
\text { Problematizar }\end{array}$ & $\begin{array}{l}\text { Pergunta de } \\
\text { problematização }\end{array}$ & \\
\hline 27 & $\begin{array}{l}\text { Pedro: [inaudível] Eu consigo explicar o que é, } \\
\text { mas porquê eu não sei. }\end{array}$ & & & \\
\hline 28 & $\begin{array}{l}\text { Professor: Não, nós não chegamos neste } \\
\text { ponto ainda. }\end{array}$ & Qualificar & & \\
\hline 29 & $\begin{array}{l}\text { Lucas: [quase inaudível, tentando explicar o } \\
\text { que está acontecendo] É igual aquela } \\
\text { experiência que a gente batia o dedo na água } \\
\text { e fazia umas ondas, elas se aumentavam, } \\
\text { aumentava não, elas ficavam juntas [entrelaça } \\
\text { os dedos das mãos] só que eu esqueci o } \\
\text { nome do fenômeno. }\end{array}$ & & & Justificativa \\
\hline 30 & Professor: Interferência de ondas? & Qualificar & & \\
\hline 31 & $\begin{array}{l}\text { Lucas: É, acho que é. Só que faz mile e anos, } \\
\text { tá ligado. }\end{array}$ & & & $\begin{array}{l}\text { Levantamento } \\
\text { de hipótese }\end{array}$ \\
\hline 32 & $\begin{array}{l}\text { Professor: Pessoal, a gente tá dizendo aqui } \\
\text { oh... A gente tá observando nesse ponto } \\
\text { [aponta para o a imagem obtida no resultado } \\
\text { experimento detector D1 de uma ilustração } \\
\text { semelhante a da fig. 2] a interferência das } \\
\text { ondas, certo? E a gente enxerga aqueles } \\
\text { pontos coloridos [refere-se aos setores } \\
\text { coloridos das imagens] quando a interferência } \\
\text { é construtiva. O que significa isso? As duas } \\
\text { frentes de onda que estão se encontrando, } \\
\text { estão na mesma fase, então elas se somam e } \\
\text { você vê o ponto claro. Quando elas estão em } \\
\text { fases opostas, a gente vê o que? A }\end{array}$ & $\begin{array}{l}\text { Retomar } \\
\text { Sintetizar } \\
\text { Qualificar }\end{array}$ & & \\
\hline
\end{tabular}




\begin{tabular}{|c|c|c|c|c|}
\hline $\mathbf{T}$ & Falas Transcritas & $\begin{array}{l}\text { Propósitos } \\
\text { Epistêmicos }\end{array}$ & $\begin{array}{l}\text { Tipo de } \\
\text { Pergunta }\end{array}$ & $\begin{array}{l}\text { Indicadores } \\
\text { de AC }\end{array}$ \\
\hline & $\begin{array}{l}\text { interferência é destrutiva, elas se anulam, não } \\
\text { é isso? O que acontece desse ponto pra esse } \\
\text { é uma inversão dessas fases, tá? }\end{array}$ & & & \\
\hline 33 & $\begin{array}{l}\text { Bruna: O que você tá falando é a explicação } \\
\text { do preto, é isso? }\end{array}$ & & & \\
\hline 34 & Professor: Ahn? & & & \\
\hline 35 & $\begin{array}{l}\text { Bruna: Tem inversão de fase, porque a parte } \\
\text { que reflete no semiespelho tá... }\end{array}$ & & & Explicação \\
\hline 36 & Professor: Tá numa fase... & Qualificar & & \\
\hline 37 & $\begin{array}{l}\text { Bruna: Numa fase diferente da que parte que } \\
\text { passou direto }\end{array}$ & & & Explicação \\
\hline 38 & $\begin{array}{l}\text { Professor: Isso. E aí o que vai tá } \\
\text { acontecendo? Vamos supor que a fase } 1 \text { tá } \\
\text { vindo pra cá e a } 2 \text { pra cá, certo? Nesse caso } \\
\text { aqui, eu vou pegar a } 1 \text { deste, né? E vai } \\
\text { interferir com a outra que tá aqui, não é isso? } \\
\text { Então o que tá acontecendo é que ela tá } \\
\text { pegando os lados simétricos, tudo bem? Bom, } \\
\text { aí a gente mudou pra fóton. Como vocês bem } \\
\text { responderam na última aula, o que acontece } \\
\text { com o padrão da figura? O resultado. }\end{array}$ & $\begin{array}{l}\text { Sintetizar } \\
\text { Retomar }\end{array}$ & $\begin{array}{l}\text { Pergunta sobre } \\
\text { dados }\end{array}$ & \\
\hline 39 & Lucas: Igual, mas pontinhos. & & & $\begin{array}{l}\text { Classificação } \\
\text { de } \\
\text { informações }\end{array}$ \\
\hline 40 & $\begin{array}{l}\text { Professor: É o mesmo, não é? O que ta } \\
\text { acontecendo só é que a gente aqui vai... } \\
\text { Quando a gente manda com o laser forma } \\
\text { imagem instantaneamente, não é isso? Todo o } \\
\text { fóton... Ele vai se distribuindo, né? E } \\
\text { dependendo da quantidade que a gente tem aí } \\
\text { a gente vai acabar observando a linha, certo? } \\
\text { Até aqui nenhuma novidade, né? Tudo bem aí, } \\
\text { Guilherme? Explica essas duas figuras aí pra } \\
\text { mim, por favor [aponta para as imagens da fig } \\
\text { 3]. Fala aí, Daniel. }\end{array}$ & $\begin{array}{l}\text { Retomar } \\
\text { Explorar }\end{array}$ & & \\
\hline 41 & Daniel: O canto de lá é... & & & \\
\hline 42 & $\begin{array}{l}\text { Professor: O canto de lá você diz a direita de } \\
\text { quem tá olhando? }\end{array}$ & & & \\
\hline 43 & $\begin{array}{l}\text { Daniel: Isso... Não, a esquerda de quem tá } \\
\text { olhando. }\end{array}$ & & & \\
\hline 44 & Alunos: Inaudível & & & \\
\hline 45 & $\begin{array}{l}\text { Professor: Vamos chamar esse de } 1 \text { e esse de } \\
2 .\end{array}$ & & & \\
\hline 46 & Daniel: Tá. O 2 é de fóton e o de cá onda. & & & \\
\hline 47 & Professor: O que eles têm de semelhante? & Explorar & $\begin{array}{l}\text { Pergunta sobre } \\
\text { dados }\end{array}$ & \\
\hline 48 & Daniel: O desenho... & & & $\begin{array}{l}\text { Organização } \\
\text { de } \\
\text { informações }\end{array}$ \\
\hline 49 & $\begin{array}{l}\text { Professor: A imagem? Tá, e o que vai ter de } \\
\text { diferente? }\end{array}$ & Explorar & $\begin{array}{l}\text { Pergunta sobre } \\
\text { dados }\end{array}$ & \\
\hline 50 & Daniel: É como se forma. & & & $\begin{array}{l}\text { Classificação } \\
\text { de } \\
\text { informações }\end{array}$ \\
\hline 51 & Professor: É o que? & Explorar & & \\
\hline 52 & $\begin{array}{l}\text { Lucas: Gradativamente, professor, conforme } \\
\text { os fótons vão chegando. }\end{array}$ & & & $\begin{array}{l}\text { Classificação } \\
\text { de } \\
\text { informações }\end{array}$ \\
\hline 53 & $\begin{array}{l}\text { Professor: Dessa maneira [aponta para a } \\
\text { imagem da fig } 3-\text { a], a formação, ela é } \\
\text { instantânea, né? E nessa aqui, [aponta apara } \\
\text { imagem da fig } 3-\text { b] ele vai se formando } \\
\text { conforme vai acontecendo a chegada das } \\
\text { partículas. }\end{array}$ & $\begin{array}{l}\text { Qualificar } \\
\text { Sintetizar }\end{array}$ & & \\
\hline
\end{tabular}




\begin{tabular}{|c|c|c|c|c|}
\hline $\mathbf{T}$ & Falas Transcritas & $\begin{array}{l}\text { Propósitos } \\
\text { Epistêmicos }\end{array}$ & $\begin{array}{l}\text { Tipo de } \\
\text { Pergunta }\end{array}$ & $\begin{array}{c}\text { Indicadores } \\
\text { de AC }\end{array}$ \\
\hline 54 & $\begin{array}{l}\text { Daniel: No laser os fótons estão todos } \\
\text { juntinhos? }\end{array}$ & & & $\begin{array}{l}\text { Levantamento } \\
\text { de hipótese }\end{array}$ \\
\hline 55 & $\begin{array}{l}\text { Professor: Não, laser a gente tem que pensar } \\
\text { na luz sendo onda. Na verdade, ora como } \\
\text { onda, ora como partícula. Bom, e aqui? Beatriz } \\
\text { S, compare essas duas figuras. [aponta para } \\
\text { as imagens da fig. 4] }\end{array}$ & Explorar & & \\
\hline 56 & $\begin{array}{l}\text { Beatriz: Na primeira, são circunferências } \\
\text { concêntricas e na segunda são conjuntos de } \\
\text { pontinhos... }\end{array}$ & & & $\begin{array}{l}\text { Organização } \\
\text { de informação }\end{array}$ \\
\hline 57 & Professor: E? Por quê? & Explorar & & \\
\hline 58 & Beatriz: Por que... & & & \\
\hline 59 & $\begin{array}{l}\text { Professor: Qual a relação? Por que forma essa } \\
\text { figura aqui e não aqui? [aponta para as } \\
\text { imagens da fig.4] }\end{array}$ & Explorar & $\begin{array}{l}\text { Pergunta } \\
\text { exploratória } \\
\text { sobre o } \\
\text { processo }\end{array}$ & \\
\hline 60 & Beatriz: Porque na primeira tem interferência. & & & $\begin{array}{l}\text { Justificativa } \\
\text { Explicação } \\
\end{array}$ \\
\hline 61 & Lucas: Professor. & & & \\
\hline 62 & Alunos: [inaudível] & & & \\
\hline 63 & Professor: Fala, Lucas. & & & \\
\hline 64 & $\begin{array}{l}\text { Lucas: Então, nos primeiros círculos as duas } \\
\text { se encontram, os dois raios estão juntos. }\end{array}$ & & & Explicação \\
\hline 65 & Professor: Pessoal. & & & \\
\hline 66 & $\begin{array}{l}\text { Lucas: Enquanto que na outra figura [fig } 5.5 \text { - } \\
\text { b] como tem um detector ele impede a } \\
\text { passagem de um dos caminhos de chegar no } \\
\text { anteparo, então só tem um caminho que o } \\
\text { fóton pode passar. Por isso, ele não forma a } \\
\text { figura. }\end{array}$ & & & $\begin{array}{l}\text { Explicação } \\
\text { Justificativa } \\
\text { Raciocínio } \\
\text { lógico }\end{array}$ \\
\hline 67 & $\begin{array}{l}\text { Professor: Tá. Então, nesse caso [aponta fig. } \\
\text { 4-b], não tem interferência, e aqui [aponta a } \\
\text { fig. 4-a] a gente tem interferência, não é isso? } \\
\text { Bom, agora o seguinte, o que a gente veio } \\
\text { conversando ao longo do ano inteirinho é que } \\
\text { a física pode explicar as coisas de duas } \\
\text { maneiras, ou como onda ou como partícula. }\end{array}$ & $\begin{array}{l}\text { Qualificar } \\
\text { Sintetizar }\end{array}$ & & \\
\hline 68 & Beatriz: A luz. & & & \\
\hline 69 & $\begin{array}{l}\text { Professor: Não, as coisas, no geral. Pra luz, } \\
\text { em particular, nós chegamos numa } \\
\text { encruzilhada. Nós chegamos numa } \\
\text { encruzilhada agora. A Bia, se eu não me } \\
\text { engano na aula passada, no finalzinho da } \\
\text { aula, colocou exatamente qual era o nosso } \\
\text { problema. Como é que eu explico, se eu } \\
\text { pensar que a luz é uma partícula e o fóton é } \\
\text { uma partícula, como é que eu explico a } \\
\text { interferência pra um único fóton? Então, é isso } \\
\text { que a mecânica quântica vai tentar conversar } \\
\text { com a gente. }\end{array}$ & $\begin{array}{l}\text { Qualificar } \\
\text { Problematizar }\end{array}$ & $\begin{array}{l}\text { Pergunta de } \\
\text { problematização }\end{array}$ & \\
\hline 70 & Vitor: Explicar como eles passam. & & & \\
\hline 71 & $\begin{array}{l}\text { Professor: Não, um único. Como é que um } \\
\text { fóton interfere com ele mesmo. [inaudível, } \\
\text { vários alunos falam ao mesmo tempo] Não, } \\
\text { não, peraí. Pessoal, diferente do que eles tão } \\
\text { dizendo aqui, não é quando a gente tem } \\
\text { assim, ah, eu tenho a luz interagindo com } \\
\text { outra coisa, aí você tá aumentando as } \\
\text { variáveis. Nós estamos pensando assim, } \\
\text { olha... Foi isso que a Bia discutiu aqui na } \\
\text { ultima aula. Como é que eu explico } \\
\text { interferência para um único fóton? Ele com ele } \\
\text { mesmo. Na nossa figurinha lá, se eu lançar } \\
\text { apenas um único fóton, entendeu? Diferente }\end{array}$ & Problematizar & & \\
\hline
\end{tabular}




\begin{tabular}{|c|c|c|c|c|}
\hline $\mathbf{T}$ & Falas Transcritas & $\begin{array}{l}\text { Propósitos } \\
\text { Epistêmicos }\end{array}$ & $\begin{array}{l}\text { Tipo de } \\
\text { Pergunta }\end{array}$ & $\begin{array}{l}\text { Indicadores } \\
\text { de AC }\end{array}$ \\
\hline & $\begin{array}{l}\text { do que a gente tinha no real, que a gente } \\
\text { manda um feixe, a gente tá mandando milhões } \\
\text { ao mesmo tempo e aí eu posso continuar } \\
\text { pensando em bolinhas colidindo uma com a } \\
\text { outra, né? Agora não, eu tenho um único e } \\
\text { nesse único eu continuo tendo interferência. }\end{array}$ & $\begin{array}{l}\text { Retomar } \\
\text { Qualificar }\end{array}$ & & \\
\hline 72 & Beatriz: Ele se dividiu ao meio. & & & $\begin{array}{l}\text { Levantamento } \\
\text { de hipótese }\end{array}$ \\
\hline 73 & $\begin{array}{l}\text { Professor: Quando ele passa lá no } \\
\text { semiespelho ele se divide em duas partes? }\end{array}$ & Explorar & & \\
\hline 74 & Beatriz: É... & & & $\begin{array}{l}\text { Levantamento } \\
\text { de hipótese }\end{array}$ \\
\hline 75 & $\begin{array}{l}\text { Professor: Mas duas partes do que? De } \\
\text { partícula? Duas partes de onda? Uma parte } \\
\text { partícula outra parte onda? }\end{array}$ & Explorar & $\begin{array}{l}\text { Pergunta de } \\
\text { problematização }\end{array}$ & \\
\hline 76 & Beatriz: Acho que as duas partes partícula. & & & $\begin{array}{l}\text { Levantamento } \\
\text { de hipótese }\end{array}$ \\
\hline 77 & $\begin{array}{l}\text { Professor: Mas aí se ele se dividir ao meio, eu } \\
\text { deixo de ter um fóton e tenho dois. Dois meio } \\
\text { fótons... }\end{array}$ & $\begin{array}{l}\text { Explorar } \\
\text { Sintetiza }\end{array}$ & & \\
\hline 78 & Beatriz: Aí depois eles se juntam. & & & $\begin{array}{l}\text { Levantamento } \\
\text { de hipótese } \\
\text { Justificativa }\end{array}$ \\
\hline 79 & Professor: Junta aqui embaixo de novo? & Explorar & & \\
\hline 80 & Beatriz: É, os dois lados. & & & Previsão \\
\hline 81 & $\begin{array}{l}\text { Professor: Mas como é que com eles juntos eu } \\
\text { posso ter no anteparo dos dois lados? Aqui... } \\
\text { Olha, a Bia ta dizendo o seguinte, aqui ele se } \\
\text { divide, certo? Aí vem pra cá e vem pra cá. } \\
\text { Quando chega aqui, se eles se juntam, como a } \\
\text { Bia ta falando, eu teria que ter observação em } \\
\text { um único anteparo, mas eu consigo medir nos } \\
\text { dois ao mesmo tempo. }\end{array}$ & $\begin{array}{l}\text { Sintetizar } \\
\text { Explorar }\end{array}$ & $\begin{array}{l}\text { Pergunta de } \\
\text { problematização }\end{array}$ & \\
\hline 82 & $\begin{array}{l}\text { Bruna: Eu estava pensando que ali no meio } \\
\text { eles se dividem de novo... }\end{array}$ & & & $\begin{array}{l}\text { Levantamento } \\
\text { de hipótese }\end{array}$ \\
\hline 83 & Professor: Meninos, por favor! & & & \\
\hline 84 & $\begin{array}{l}\text { Bruna: Vai passar uma parte ali e a outra vai } \\
\text { por ali, ó [aponta a figura]. }\end{array}$ & & & $\begin{array}{l}\text { Teste de } \\
\text { Hipótese }\end{array}$ \\
\hline 85 & $\begin{array}{l}\text { Professor: Dois que vem pra cá e dois que } \\
\text { vem pra cá? }\end{array}$ & Explorar & & \\
\hline 86 & Bruna: Não sei, mas foi o que pensei. & & & Previsão \\
\hline 87 & $\begin{array}{l}\text { Professor: Pode ser isso, gente? Bom, aqui ele } \\
\text { se divide em dois, metade vem pra cá e a } \\
\text { outra metade vem pra cá. Quando chega } \\
\text { aqui... Ou tenho quatro ou tenho dois de novo, } \\
\text { né? Porque eu posso pegar assim, metade } \\
\text { desse que vem pra cá com a metade desse } \\
\text { que forma um. Aí metade vem pra cá... Eu } \\
\text { posso ter quatro partes, mas elas são } \\
\text { agrupadas duas aqui, duas aqui? Pode ser } \\
\text { isso? }\end{array}$ & $\begin{array}{l}\text { Problematizar } \\
\text { Explorar }\end{array}$ & $\begin{array}{l}\text { Pergunta } \\
\text { exploratória } \\
\text { sobre } \\
\text { processo }\end{array}$ & \\
\hline 88 & Pedro: Inaudível. & & & \\
\hline 89 & $\begin{array}{l}\text { Professor: Continua tendo colisão. Então pode } \\
\text { ser o que, Pedro? }\end{array}$ & Explorar & & \\
\hline 90 & Pedro: Não sei. & & & \\
\hline 91 & $\begin{array}{l}\text { Professor: Eu não to dizendo que não pode, } \\
\text { eu só to perguntando. }\end{array}$ & & & \\
\hline 92 & Pedro: Vai um pra cada lado. & & & \\
\hline 93 & Professor: E aí? & Explorar & & \\
\hline 94 & Beatriz: [Inaudível] & & & \\
\hline 95 & Pedro: um espermatozoide & & & $\begin{array}{l}\text { Levantamento } \\
\text { de hipótese }\end{array}$ \\
\hline 96 & Beatriz: Não é uma célula. & & & \\
\hline
\end{tabular}




\begin{tabular}{|c|c|c|c|c|}
\hline $\mathbf{T}$ & Falas Transcritas & $\begin{array}{l}\text { Propósitos } \\
\text { Epistêmicos }\end{array}$ & $\begin{array}{l}\text { Tipo de } \\
\text { Pergunta }\end{array}$ & $\begin{array}{l}\text { Indicadores } \\
\text { de AC }\end{array}$ \\
\hline 97 & $\begin{array}{l}\text { Professor: E aí? Como é que fica a situação? } \\
\text { Bom, olhando pro nosso quadrinho... Oi. }\end{array}$ & Explorar & & \\
\hline 98 & Beatriz: Tinha... [inaudível] & & & \\
\hline 99 & $\begin{array}{l}\text { Professor: Tinha também. Vamos pensar o } \\
\text { seguinte, olhando aí pro quadrinho de vocês } \\
\text { [faz referência a folha da atividade de } \\
\text { sistematização que os alunos tem em mãos], } \\
\text { tá? Existem várias interpretações pra essa } \\
\text { situação, tá? A mecânica quântica apresenta } \\
\text { quatro em particular. Elas são as quatro mais } \\
\text { discutidas. Quatro possíveis pensamentos pra } \\
\text { gente tentar entender a natureza da luz. }\end{array}$ & $\begin{array}{l}\text { Qualificar } \\
\text { Problematizar }\end{array}$ & & \\
\hline 100 & Beatriz: Existem outras? & & & \\
\hline 101 & $\begin{array}{l}\text { Professor: Existem, mas assim, as quatro } \\
\text { principais são essas aqui. Não é pra copiar. }\end{array}$ & Qualificar & & \\
\hline 102 & Bruna: Ta. & & & \\
\hline 103 & Professor: Tá, né? Porque eu pedi. & & & \\
\hline 104 & Bruna: Eu já parei. & & & \\
\hline 105 & $\begin{array}{l}\text { Professor: Já tava com a caneta pronta... } \\
\text { Vamos pensar antes da gente olhar lá o que tá } \\
\text { escrito. A gente tem uma interpretação que } \\
\text { recebe o nome de ondulatória. Segundo essa } \\
\text { interpretação a luz é? }\end{array}$ & Problematizar & $\begin{array}{l}\text { Pergunta } \\
\text { exploratória } \\
\text { sobre o } \\
\text { processo }\end{array}$ & \\
\hline 106 & Alunos: Onda. & & & $\begin{array}{l}\text { Classificação } \\
\text { de informação }\end{array}$ \\
\hline 107 & $\begin{array}{l}\text { Professor: A gente tem uma interpretação que } \\
\text { é a corpuscular. }\end{array}$ & Problematizar & & \\
\hline 108 & Lucas: Partícula. São os fótons! & & & $\begin{array}{l}\text { Classificação } \\
\text { de informação }\end{array}$ \\
\hline 109 & $\begin{array}{l}\text { Professor: São fótons. Fóton é uma partícula } \\
\text { de luz! Existe uma interpretação... Vou pular } \\
\text { pra ultima... Dualista. }\end{array}$ & $\begin{array}{l}\text { Sintetizar } \\
\text { Problematizar }\end{array}$ & & \\
\hline 110 & Bruna: Ora como onda e como partícula. & & & $\begin{array}{l}\text { Classificação } \\
\text { de informação }\end{array}$ \\
\hline 111 & Beatriz: Onda e Partícula. & & & $\begin{array}{l}\text { Classificação } \\
\text { de informação }\end{array}$ \\
\hline 112 & Lucas: É onda e partícula? & & & $\begin{array}{l}\text { Levantamento } \\
\text { de hipótese }\end{array}$ \\
\hline 113 & $\begin{array}{l}\text { Professor: Que ela pode ser as duas coisas ao } \\
\text { mesmo tempo. E uma partícula que é } \\
\text { associada com uma onda ou uma onda com } \\
\text { uma partícula... }\end{array}$ & Sintetizar & & \\
\hline 114 & Alunos: Inaudível. & & & \\
\hline 115 & $\begin{array}{l}\text { Pedro: Você falou que não tem como, que não } \\
\text { pode ser onda e partícula ao mesmo tempo. }\end{array}$ & & & \\
\hline 116 & $\begin{array}{l}\text { Professor: Então, aí cai nessa situação que o } \\
\text { Pedro ta falando, né? }\end{array}$ & Explorar & & \\
\hline 117 & Beatriz: Ela é uma coisa e outra. & & & \\
\hline 118 & $\begin{array}{l}\text { Professor: É... Pra mecânica clássica isso não } \\
\text { é possível. }\end{array}$ & Qualificar & & \\
\hline 119 & Beatriz: Mas e em Quântica... & & & Justificativa \\
\hline 120 & Pedro: Acho que é. & & & $\begin{array}{l}\text { Levantamento } \\
\text { de hipótese }\end{array}$ \\
\hline 121 & $\begin{array}{l}\text { Professor: Mas em física moderna a gente vai } \\
\text { ter que arrumar uma nova explicação. E essa } \\
\text { nova explicação, então, pode ser que ela seja } \\
\text { as duas coisas ao mesmo tempo? }\end{array}$ & Problematizar & & \\
\hline 122 & Beatriz S: Acho que sim. & & & $\begin{array}{l}\text { Levantamento } \\
\text { de hipótese }\end{array}$ \\
\hline 123 & Professor: E complementaridade? & Explorar & $\begin{array}{l}\text { Pergunta } \\
\text { exploratória } \\
\text { sobre o } \\
\text { processo }\end{array}$ & \\
\hline
\end{tabular}




\begin{tabular}{|c|c|c|c|c|}
\hline $\mathbf{T}$ & Falas Transcritas & $\begin{array}{l}\text { Propósitos } \\
\text { Epistêmicos }\end{array}$ & $\begin{array}{l}\text { Tipo de } \\
\text { Pergunta }\end{array}$ & $\begin{array}{l}\text { Indicadores } \\
\text { de AC }\end{array}$ \\
\hline 124 & Pedro: As duas se complementam. & & & $\begin{array}{l}\text { Levantamento } \\
\text { de hipótese }\end{array}$ \\
\hline 125 & Bruna: Uma completa a outra. & & & $\begin{array}{l}\text { Levantamento } \\
\text { de hipótese }\end{array}$ \\
\hline 126 & Professor: Então, segundo a Beatriz. & & & \\
\hline 127 & Pedro: [Inaudível] & & & \\
\hline 128 & Bruna: Pedro, para! & & & \\
\hline 129 & $\begin{array}{l}\text { Professor: Não, mas essa ideia que o Pedro ta } \\
\text { falando tem mais a ver com a dualista, né? } \\
\text { Num é? }\end{array}$ & Explorar & & \\
\hline 130 & Pedro: É... & & & \\
\hline 131 & $\begin{array}{l}\text { Lucas: Professor, e se eu disser que a luz é } \\
\text { partícula... }\end{array}$ & & & $\begin{array}{l}\text { Levantamento } \\
\text { de hipótese }\end{array}$ \\
\hline 132 & $\begin{array}{l}\text { Professor: Silêncio, eu não estou ouvindo o } \\
\text { Lucas que tá quase do meu lado. Fala, Lucas. }\end{array}$ & & & \\
\hline 133 & $\begin{array}{l}\text { Lucas: E se eu falar que a luz é partícula com } \\
\text { fatores ondulatórios ou é onda com fator de } \\
\text { partícula? }\end{array}$ & & & $\begin{array}{l}\text { Levantamento } \\
\text { de hipótese }\end{array}$ \\
\hline 134 & $\begin{array}{l}\text { Professor: Aí nesse caso, você acha que vai ta } \\
\text { dentro de qual dessas interpretações? }\end{array}$ & Problematizar & $\begin{array}{l}\text { Pergunta } \\
\text { exploratória } \\
\text { sobre } \\
\text { processo }\end{array}$ & \\
\hline 135 & $\begin{array}{l}\text { Lucas: Então, mas assim, no meu raciocínio } \\
\text { ela segue um caminho, mas só que o que } \\
\text { complementa ela é o outro. }\end{array}$ & & & Explicação \\
\hline 136 & $\begin{array}{l}\text { Professor: Dá pra encaixar, não dá? Dentro de } \\
\text { uma dessas interpretações. Fala aí, Karina. }\end{array}$ & Problematizar & & \\
\hline 137 & Karina: Não sei. & & & \\
\hline 138 & Vitor: Posso tentar? & & & \\
\hline 139 & Professor: Pode. & & & \\
\hline 140 & $\begin{array}{l}\text { Vitor: Tipo, microscopicamente é uma } \\
\text { partícula, macroscopicamente ela é uma onda. }\end{array}$ & & & $\begin{array}{l}\text { Levantamento } \\
\text { de hipótese }\end{array}$ \\
\hline 141 & $\begin{array}{l}\text { Professor: Ta. Segundo o Vitor, se a gente } \\
\text { olhar lá no microscópio... Microscópio não, se } \\
\text { olhar no mundo dos micro, né? Se for pensar } \\
\text { nela lá, enquanto natureza mesmo, na sua } \\
\text { formação ela é? }\end{array}$ & $\begin{array}{l}\text { Sintetizar } \\
\text { Problematizar }\end{array}$ & & \\
\hline 142 & Vitor: Partícula. & & & \\
\hline 143 & $\begin{array}{l}\text { Professor: Partícula. Mas se a gente observar } \\
\text { de fora, no macroscópico, é isso? Aí ela é } \\
\text { onda. Pode ser isso? }\end{array}$ & & $\begin{array}{l}\text { Pergunta } \\
\text { exploratória } \\
\text { sobre } 0 \\
\text { processo }\end{array}$ & \\
\hline 144 & & & & \\
\hline 145 & $\begin{array}{l}\text { Professor: Pra } \\
\text { complementaridade? }\end{array}$ & Explorar & $\begin{array}{l}\text { Pergunta } \\
\text { exploratória } \\
\text { sobre o } \\
\text { processo }\end{array}$ & \\
\hline 146 & Beatriz: $\dot{E}$ & & & \\
\hline 147 & Vitor: Sim. & & & \\
\hline 148 & Bruna: Pra mim não é. & & & $\begin{array}{l}\text { Levantamento } \\
\text { de hipótese }\end{array}$ \\
\hline 149 & Professor: Pra você é o que isso? & Explorar & $\begin{array}{l}\text { Pergunta } \\
\text { exploratória } \\
\text { sobre o } \\
\text { processo }\end{array}$ & \\
\hline 150 & $\begin{array}{l}\text { Bruna: Porque aí ela tá sendo duas coisas ao } \\
\text { mesmo tempo. Complementaridade é quando } \\
\text { ela tá sendo ora uma coisa ora outra. }\end{array}$ & & & $\begin{array}{l}\text { Justificativa } \\
\text { Explicação }\end{array}$ \\
\hline 151 & Vitor: Então... & & & \\
\hline 152 & $\begin{array}{l}\text { Bruna: Não. Porque o que eu to falando... No } \\
\text { micro... Olha, no mesmo momento quando } \\
\text { você analisa no micro ela é partícula e no } \\
\text { macro ela é onda. Você tá pensando no }\end{array}$ & & & $\begin{array}{l}\text { Justificativa } \\
\text { Raciocínio } \\
\text { lógico }\end{array}$ \\
\hline
\end{tabular}




\begin{tabular}{|c|c|c|c|c|}
\hline $\mathbf{T}$ & Falas Transcritas & $\begin{array}{l}\text { Propósitos } \\
\text { Epistêmicos }\end{array}$ & $\begin{array}{l}\text { Tipo de } \\
\text { Pergunta }\end{array}$ & $\begin{array}{l}\text { Indicadores } \\
\text { de AC }\end{array}$ \\
\hline & $\begin{array}{l}\text { mesmo momento, então na mesma coisa ela } \\
\text { tá sendo duas coisas ao mesmo tempo. Mas } \\
\text { pra ser complementar no momento " } x \text { " ela tá } \\
\text { sendo uma coisa e no momento " } y \text { " ela tá } \\
\text { sendo outra, entendeu? }\end{array}$ & & & \\
\hline 153 & Vitor: Depende da perspectiva... & & & $\begin{array}{l}\text { Levantamento } \\
\text { de hipótese }\end{array}$ \\
\hline 154 & Alunos: Inaudível. & & & \\
\hline 155 & $\begin{array}{l}\text { Professor: Vamos falar um por vez, gente. Ta } \\
\text { boa a discussão, mas vamos falar um por vez. }\end{array}$ & & & \\
\hline 156 & Alunos: [Inaudível] & & & \\
\hline 157 & $\begin{array}{l}\text { Lucas: Então, mas não pode ser só a energia } \\
\text { que tá passando de uma partícula pra outra? }\end{array}$ & & & $\begin{array}{l}\text { Levantamento } \\
\text { de hipótese }\end{array}$ \\
\hline 158 & $\begin{array}{l}\text { Professor: Não, a onda... Mas não é energia, é } \\
\text { perturbação. A onda carrega energia. }\end{array}$ & Qualificar & & \\
\hline 159 & Lucas: A onda carrega energia? & & & \\
\hline 160 & $\begin{array}{l}\text { Aline: Eu não sei... Eu acho que é que nem ele } \\
\text { falou. Uma hora ela se comporta de uma } \\
\text { forma, como onda e outra hora como partícula. }\end{array}$ & & & $\begin{array}{l}\text { Levantamento } \\
\text { de hipótese }\end{array}$ \\
\hline 161 & $\begin{array}{l}\text { Professor: Mas aí se ela se comporta ora de } \\
\text { um jeito, ora de outro ela é o que? }\end{array}$ & Explorar & $\begin{array}{l}\text { Pergunta } \\
\text { exploratória } \\
\text { sobre o } \\
\text { processo }\end{array}$ & \\
\hline 162 & Aline: Complementaridade... & & & $\begin{array}{l}\text { Classificação } \\
\text { de informação }\end{array}$ \\
\hline 163 & $\begin{array}{l}\text { Professor: Não, ela é o que? Olha, pra } \\
\text { primeira vocês falaram assim é uma onda. Pra } \\
\text { segunda vocês falaram assim é uma partícula. } \\
\text { Pra ultima vocês tão falando que é as duas } \\
\text { coisas ao mesmo tempo. E na } \\
\text { complementaridade ela é o que? }\end{array}$ & $\begin{array}{l}\text { Sintetizar } \\
\text { Explorar }\end{array}$ & $\begin{array}{l}\text { Pergunta } \\
\text { exploratória } \\
\text { sobre o } \\
\text { processo }\end{array}$ & \\
\hline 164 & Aline: Não sei. & & & \\
\hline 165 & $\begin{array}{l}\text { Lucas: Ah... Depois de tantos experimentos } \\
\text { pra ver se é onda, onda mesmo ou se é } \\
\text { partícula, partícula mesmo... Mas o que } \\
\text { aconteceu, acabou ocorrendo fatores que } \\
\text { defendiam } 100 \% \text { que é onda enquanto que } \\
\text { outro defendia } 100 \% \text { que era partícula. Então, } \\
\text { aí eu pensei, através disso, a onda pensando } \\
\text { num só ele recebe complemento de ambas as } \\
\text { partes. Ela não pode ser definida só como } \\
\text { onda, nem só como partícula. }\end{array}$ & & & $\begin{array}{l}\text { Raciocínio } \\
\text { lógico } \\
\text { Justificativa } \\
\text { Explicação }\end{array}$ \\
\hline 166 & $\begin{array}{l}\text { Professor: Então a gente não tem definição } \\
\text { pra esse caso? }\end{array}$ & Explorar & $\begin{array}{l}\text { Pergunta } \\
\text { exploratória } \\
\text { sobre o } \\
\text { processo }\end{array}$ & \\
\hline 167 & Rafaela: Não. & & & Explicação \\
\hline 168 & Professor: Não sei. Tô falando pelo Lucas. & & & \\
\hline 169 & Rafaela: Vamos passar pra próxima. & & & \\
\hline 170 & $\begin{array}{l}\text { Professor: Vamos deixar em branco por } \\
\text { enquanto? }\end{array}$ & & & \\
\hline 171 & Rafaela: Vamos. & & & \\
\hline 172 & Lucas: Não. & & & \\
\hline 173 & Bruna: Não. & & & \\
\hline 174 & Lucas: [Inaudível] & & & \\
\hline 175 & $\begin{array}{l}\text { Professor: Vamos pra linha de baixo. Pra cada } \\
\text { uma dessas interpretações, como é que a } \\
\text { gente, como é que a gente explica a } \\
\text { experiência do interferômetro? Supondo que a } \\
\text { gente... Vamos explicar o interferômetro ideal, } \\
\text { já que nem todo mundo conseguiu ver no real. } \\
\text { Como é que a gente explica a figura? Essa } \\
\text { figura } 1 \text { que ta ali [aponta para o resultado }\end{array}$ & $\begin{array}{l}\text { Problematizar } \\
\text { Qualificar }\end{array}$ & $\begin{array}{l}\text { Pergunta } \\
\text { exploratória } \\
\text { sobre o } \\
\text { processo }\end{array}$ & \\
\hline
\end{tabular}




\begin{tabular}{|c|c|c|c|c|}
\hline $\mathbf{T}$ & Falas Transcritas & $\begin{array}{l}\text { Propósitos } \\
\text { Epistêmicos }\end{array}$ & $\begin{array}{l}\text { Tipo de } \\
\text { Pergunta }\end{array}$ & $\begin{array}{l}\text { Indicadores } \\
\text { de AC }\end{array}$ \\
\hline & $\begin{array}{l}\text { obtido por meio do IMZ virtual, conforme a fig. } \\
\text { 2]. Se é uma onda, como é que a gente pode } \\
\text { explicar a interferência? }\end{array}$ & & & \\
\hline 176 & Bruna: Inaudível. & & & \\
\hline 177 & Professor: Fala alto. & & & \\
\hline 178 & Bruna: Inaudível. & & & \\
\hline 179 & Professor: Não entendi. & & & \\
\hline 180 & $\begin{array}{l}\text { Beatriz: Aquele negócio de ondas destrutivas e } \\
\text { construtivas. }\end{array}$ & & & Explicação \\
\hline 181 & $\begin{array}{l}\text { Professor: Ah, aquele negócio de ondas } \\
\text { construtivas e destrutivas, foi isso que você } \\
\text { falou? }\end{array}$ & Explorar & & \\
\hline 182 & Bruna: É. & & & \\
\hline 183 & $\begin{array}{l}\text { Professor: Ainda bem que tem um } \\
\text { amplificador. Tá, é assim que todo mundo } \\
\text { acha? Eu consigo explicar a interferência } \\
\text { como sendo duas ondas... Fase igual constrói, } \\
\text { fases diferentes elas se anulam, é isso? } \\
\text { Alguém tem outra ideia pra explicar isso? }\end{array}$ & $\begin{array}{l}\text { Explorar } \\
\text { Sintetizar }\end{array}$ & $\begin{array}{l}\text { Pergunta } \\
\text { exploratória } \\
\text { sobre o } \\
\text { processo }\end{array}$ & \\
\hline 184 & Alunos: Inaudível. & & & \\
\hline 185 & $\begin{array}{l}\text { Bruna: É... Pra ter interferência tem que ter } \\
\text { duas ondas. Quando elas tão na mesma fase, } \\
\text { você vai ter a interferência construtiva que vai } \\
\text { aumentar. Agora quando tá tendo... De um } \\
\text { lado você tá tendo a voltinha assim e do outro } \\
\text { ao contrário vai ser destrutiva, então vai } \\
\text { diminuir. Se forem iguais os valores vai acabar } \\
\text { com a onda. Isso se forem ondas, agora se for } \\
\text { complementar aí eu não sei explicar. }\end{array}$ & & & $\begin{array}{l}\text { Explicação } \\
\text { Raciocínio } \\
\text { lógico }\end{array}$ \\
\hline 186 & $\begin{array}{l}\text { Professor: E como partícula? Como é que a } \\
\text { gente explica isso? Alguém que não falou } \\
\text { ainda... Felipe, Priscila, Talita, John... Como é } \\
\text { que eu explico essa interferência se for } \\
\text { partícula? }\end{array}$ & Problematizar & $\begin{array}{l}\text { Pergunta } \\
\text { exploratória } \\
\text { sobre o } \\
\text { processo }\end{array}$ & \\
\hline 187 & Felipe: Parte é onda e parte é partícula... & & & $\begin{array}{l}\text { Levantamento } \\
\text { de hipótese }\end{array}$ \\
\hline 188 & $\begin{array}{l}\text { Alunos: Mas como se só tem fótons... } \\
\text { [Inaudível] }\end{array}$ & & & \\
\hline 189 & Professor: Calma, deixa o rapaz pensar. & & & \\
\hline 190 & Beatriz: A da complementaridade... & & & \\
\hline 191 & $\begin{array}{l}\text { Professor: Você tá pulando a pergunta Beatriz. } \\
\text { Se a gente juntasse a ideia que o Felipe tá } \\
\text { lançando com o que a Bia tinha dito a pouco, a } \\
\text { ideia da divisão, será que daria pra explicar? E } \\
\text { vamos falar baixo pra não acordar a Zineck. E } \\
\text { aí? Dá pra explicar como... Será que dá? Eu } \\
\text { pego a partícula, quando ela passa ali [aponta } \\
\text { para o semiespelho } \mathrm{S} 1 \text {, conforme ilustrado na } \\
\text { figura 1], ela se divide, depois na hora que } \\
\text { elas se encontram elas vão colidir, se juntam } \\
\text { um pouco, tal... O que a gente tava discutindo } \\
\text { antes, aí junta o que o Felipe Tava } \\
\text { conversando. Pode ser um caminho? } \\
\text { Pessoas? Fala aí, Carlos! Sem comentários? }\end{array}$ & $\begin{array}{l}\text { Problematizar } \\
\text { Sintetizar }\end{array}$ & $\begin{array}{l}\text { Pergunta } \\
\text { exploratória } \\
\text { sobre o } \\
\text { processo }\end{array}$ & \\
\hline 192 & Carlos: Isso aí. & & & \\
\hline 193 & $\begin{array}{l}\text { Professor: Fala aí Bia, o que você queria } \\
\text { explicar então da... Como é que você explica o } \\
\text { interferômetro? }\end{array}$ & Explorar & & \\
\hline 194 & Alunos: Inaudível. & & & \\
\hline 195 & Professor: Fala, Bia. & & & \\
\hline 196 & Beatriz: Ele tá falando aqui... [Inaudível] & & & \\
\hline 197 & $\begin{array}{l}\text { Professor: Não, mas como é que você explica } \\
\text { interferência? }\end{array}$ & Explorar & & \\
\hline
\end{tabular}




\begin{tabular}{|c|c|c|c|c|}
\hline $\mathbf{T}$ & Falas Transcritas & $\begin{array}{l}\text { Propósitos } \\
\text { Epistêmicos }\end{array}$ & $\begin{array}{l}\text { Tipo de } \\
\text { Pergunta }\end{array}$ & $\begin{array}{l}\text { Indicadores } \\
\text { de AC }\end{array}$ \\
\hline 198 & Beatriz: Ah... & & & \\
\hline 199 & Professor: Pensando na complementaridade. & $\begin{array}{l}\text { Explorar } \\
\text { Qualificar }\end{array}$ & $\begin{array}{l}\text { Pergunta } \\
\text { exploratória } \\
\text { sobre o } \\
\text { processo }\end{array}$ & \\
\hline 200 & Beatriz: Não sei.... & & & \\
\hline 201 & Professor: Falem mais. & & & \\
\hline 202 & Alunos: Estamos tentando... & & & \\
\hline 203 & $\begin{array}{l}\text { Professor: E aí? Tá bom, vamos pro último } \\
\text { então. Dualista-realista. Vocês disseram que... } \\
\text { Nossa! }\end{array}$ & & & \\
\hline 204 & Alunos: [Inaudível] & & & \\
\hline 205 & $\begin{array}{l}\text { Professor: É... Dualista-realista vocês falaram } \\
\text { que a luz era as duas coisas ao mesmo } \\
\text { tempo. A interferência acaba sendo o que? } \\
\text { Como é que eu explico a interferência na } \\
\text { dualista? E aí, pessoal? Pra última } \\
\text { interpretação vocês disseram que a luz era as } \\
\text { duas coisas ao mesmo tempo, onda e } \\
\text { partícula. }\end{array}$ & $\begin{array}{l}\text { Sintetizar } \\
\text { Problematizar } \\
\text { Explorar }\end{array}$ & $\begin{array}{l}\text { Pergunta } \\
\text { exploratória } \\
\text { sobre o } \\
\text { processo }\end{array}$ & \\
\hline 206 & Bruna: [Inaudível] & & & \\
\hline 207 & Professor: Nós pulamos a complementaridade. & & & \\
\hline 208 & Bruna: [Inaudível] & & & \\
\hline 209 & $\begin{array}{l}\text { Professor: Falou. A gente juntou a ideia do } \\
\text { Felipe com o que a Bia tinha dito antes da } \\
\text { ideia de dividir o fóton no meio e tal... }\end{array}$ & Sintetizar & & \\
\hline 210 & Bruna: Fóton se dividindo. & & & \\
\hline 211 & Professor: Com o que? & & & \\
\hline 212 & Bruna: Fóton se dividindo. & & & \\
\hline 213 & $\begin{array}{l}\text { Professor: Isso. E depois a colisão deles foi o } \\
\text { que o Felipe tinha dito àquela hora. E aí? Se } \\
\text { ela é as duas coisas ao mesmo tempo na } \\
\text { quarta interpretação como é que eu explico a } \\
\text { interferência? Ela vai se comportar como o } \\
\text { que? }\end{array}$ & $\begin{array}{l}\text { Qualificar } \\
\text { Sintetizar } \\
\text { Problematizar }\end{array}$ & $\begin{array}{l}\text { Pergunta } \\
\text { exploratória } \\
\text { sobre o } \\
\text { processo }\end{array}$ & \\
\hline 214 & Vitor: Os dois. & & & $\begin{array}{l}\text { Levantamento } \\
\text { de hipótese }\end{array}$ \\
\hline 215 & $\begin{array}{l}\text { Professor: Mas a gente não falou que } \\
\text { interferência só acontece quando tem onda? }\end{array}$ & $\begin{array}{l}\text { Problematizar } \\
\text { Explorar }\end{array}$ & $\begin{array}{l}\text { Pergunta de } \\
\text { problematização }\end{array}$ & \\
\hline 216 & Bruna: [Inaudível] & & & \\
\hline 217 & $\begin{array}{l}\text { Professor: Não, antes, quando a gente teve } \\
\text { aquele problema da interferência. Que não } \\
\text { dava pra explicar como sendo partícula } \\
\text { simplesmente. Aqui só falou que é uma } \\
\text { partícula diferente, não é a mesma partícula, } \\
\text { não dá pra pensar a partícula como a gente } \\
\text { pensava antes da bolinha, com a massa, se } \\
\text { for pensar nessa partícula tem algo que não tá } \\
\text { certo. Tem que ser uma outra partícula } \\
\text { diferente. Mas agora neste caso aqui ele tá } \\
\text { dizendo que ela é onda e partícula ao mesmo } \\
\text { tempo. Fica em branco ainda? Vamos... Agora } \\
\text { não anotem, por favor. Eu vou apresentar pra } \\
\text { vocês essas quatro interpretações. E aí tá } \\
\text { dizendo o seguinte... Se a gente interpretar a } \\
\text { luz como sendo onda, a gente vai explicar a } \\
\text { interferência, que essa onda se divide em dois } \\
\text { meio fótons no primeiro semiespelho, ta certo? } \\
\text { E eles vão se recombinar lá no segundo como } \\
\text { se fosse uma onda, né? Produzindo a } \\
\text { interferência que a gente observa lá, certo? } \\
\text { Essa interpretação que a Bia e o Felipe } \\
\text { estavam colocando agora pouco é a } \\
\text { interpretação pra onda. Se a gente ta }\end{array}$ & Sintetizar & & \\
\hline
\end{tabular}




\begin{tabular}{|c|c|c|c|c|}
\hline $\mathbf{T}$ & Falas Transcritas & $\begin{array}{l}\text { Propósitos } \\
\text { Epistêmicos }\end{array}$ & $\begin{array}{l}\text { Tipo de } \\
\text { Pergunta }\end{array}$ & $\begin{array}{l}\text { Indicadores } \\
\text { de AC }\end{array}$ \\
\hline & pensando como... & & & \\
\hline 218 & Beatriz: Foi o que eu falei, o fóton é onda. & & & \\
\hline 219 & $\begin{array}{l}\text { Professor: O fóton como sendo uma onda, } \\
\text { certo? O fóton é uma onda e aí você tem o } \\
\text { quê? Você divide ao meio no primeiro } \\
\text { semiespelho, quando ele chega no segundo } \\
\text { semiespelho ele se junta novamente e aí a } \\
\text { gente tem a interferência. Agora, na segunda } \\
\text { interpretação o fóton é uma partícula e aí ela } \\
\text { não se divide nunca, ta certo? }\end{array}$ & & & \\
\hline 220 & Beatriz: Por que uma partícula não se divide? & & $\begin{array}{l}\text { Pergunta de } \\
\text { problematização }\end{array}$ & $\begin{array}{l}\text { Teste de } \\
\text { hipótese }\end{array}$ \\
\hline 221 & $\begin{array}{l}\text { Professor: Não. É a menor porção que a gente } \\
\text { pode ter. E aí neste caso, qual o único fóton... } \\
\text { Ah... Como é que eu vou explicar a } \\
\text { interferência? }\end{array}$ & Problematizar & $\begin{array}{l}\text { Pergunta } \\
\text { exploratória } \\
\text { sobre o } \\
\text { processo }\end{array}$ & \\
\hline 222 & Lucas: Um único fóton é uma única partícula... & & & $\begin{array}{l}\text { Classificação } \\
\text { Organização }\end{array}$ \\
\hline 223 & Professor: Ahn? & & & \\
\hline 224 & Lucas: Pra um só fóton... & & & \\
\hline 225 & Professor: Pra um único fóton. & & & \\
\hline 226 & $\begin{array}{l}\text { Lucas: Pra um fóton é só um caminho, mas } \\
\text { pra vários você pode ter mais de um. }\end{array}$ & & & Explicação \\
\hline 227 & Professor: Não entendi. & & & \\
\hline 228 & $\begin{array}{l}\text { Lucas: Então, mas tem a possibilidade de ter } \\
\text { mais de um caminho, porque tem mais de } \\
\text { um... }\end{array}$ & & & Explicação \\
\hline 229 & Professor: Então, um único fóton segue... & & & \\
\hline 230 & Lucas: Um caminho... & & & \\
\hline 231 & $\begin{array}{l}\text { Professor: Um caminho. Pra um único fóton o } \\
\text { que acontece? Como é que eu enxergo? } \\
\text { Como é que eu consigo ver a interferência? }\end{array}$ & $\begin{array}{l}\text { Explorar } \\
\text { Problematizar }\end{array}$ & $\begin{array}{l}\text { Pergunta } \\
\text { exploratória } \\
\text { sobre o } \\
\text { processo }\end{array}$ & \\
\hline 232 & Lucas: Não vê, só segue um caminho. & & & Explicação \\
\hline 233 & Alunos: [inaudível] & & & \\
\hline 234 & $\begin{array}{l}\text { Professor: Ele vai seguir um único caminho, } \\
\text { ele vai tá lá e o que a gente vai tá observando, } \\
\text { a gente vai ter mais um. Aí ele pode ser } \\
\text { refletido ou transmitido passando por lá, tá? } \\
\text { Mas a gente não vai ter... }\end{array}$ & Sintetizar & & \\
\hline 235 & Lucas: Professor. & & & \\
\hline 236 & Professor: Oi. & & & \\
\hline 237 & $\begin{array}{l}\text { Lucas: Colocando aí mais de um fóton como } \\
\text { partícula. }\end{array}$ & & & $\begin{array}{l}\text { Levantamento } \\
\text { de hipótese }\end{array}$ \\
\hline 238 & $\begin{array}{l}\text { Professor: Então, mais aí pra mais de um a } \\
\text { gente pode explicar como onda ou como } \\
\text { partícula. Tem vários ali, aí eu posso pegar o } \\
\text { raciocínio que eles fizeram lá das colisões, tá? } \\
\text { Dualista realista, o fóton ele tem duas partes. } \\
\text { É como se a gente tivesse, pensando lá na } \\
\text { analogia que você tava fazendo agora pouco } \\
\text { com a Biologia, vamos pensar num } \\
\text { espermatozoide. Então você tem lá uma } \\
\text { particulazinha e um rabinho lá que é a onda } \\
\text { que tá associada, tá? Na interpretação dualista } \\
\text { realista, a gente tem, então, a partícula é um } \\
\text { surfista que tá viajando numa onda. Então tem } \\
\text { uma partícula que tá caminhando numa onda, } \\
\text { certo? Então neste caso a gente tem, né? A } \\
\text { luz, ela é duas coisas ao mesmo tempo, que } \\
\text { era a previsão de vocês dois, certo? E aí como } \\
\text { é que eu vou explicar a interferência? A onda } \\
\text { pode se separar lá no semiespelho, e aí a } \\
\text { gente vai ter... Ela vai recombinar depois lá na }\end{array}$ & Sintetizar & & \\
\hline
\end{tabular}




\begin{tabular}{|c|c|c|c|c|}
\hline $\mathbf{T}$ & Falas Transcritas & $\begin{array}{l}\text { Propósitos } \\
\text { Epistêmicos }\end{array}$ & $\begin{array}{l}\text { Tipo de } \\
\text { Pergunta }\end{array}$ & $\begin{array}{l}\text { Indicadores } \\
\text { de AC }\end{array}$ \\
\hline & $\begin{array}{l}\text { frente. Eu consigo explicar com a parte onda, } \\
\text { né? Do fóton... }\end{array}$ & & & \\
\hline 239 & Bruna: O fóton segue como onda & & & $\begin{array}{l}\text { Levantamento } \\
\text { de hipótese }\end{array}$ \\
\hline 240 & $\begin{array}{l}\text { Professor: Ele segue um caminho onde eu } \\
\text { consigo detectar e a onda pode seguir ali pelo } \\
\text { outro lado. Eles se separam ali, depois se } \\
\text { recombinam. Tudo bem? Certo, Carlos? O que } \\
\text { foi mesmo que a Bia tinha perguntado? }\end{array}$ & Sintetizar & & \\
\hline 241 & Carlos: Não ouvi, professor. & & & \\
\hline 242 & $\begin{array}{l}\text { Professor: Pra variar, né? Nas últimas cinco } \\
\text { aulas isso tem acontecido. }\end{array}$ & & & \\
\hline 243 & Carlos: [Inaudível] & & & \\
\hline 244 & $\begin{array}{l}\text { Professor: Quer que eu lembre? Minha } \\
\text { memória tá bem. No LIEA você ficou } \\
\text { conversando no cantinho lá. Na aula passada } \\
\text { eu chamei sua atenção e da Karina que vocês } \\
\text { tavam conversando, você tava fazendo um } \\
\text { desenho, até entregou pra Bia, tá certo? Essa } \\
\text { é a terceira aula, quer mais duas pra trás? Eu } \\
\text { lembro. }\end{array}$ & & & \\
\hline 245 & Carlos: Não, tá bom só. & & & \\
\hline 246 & Alunos: [Inaudível] & & & \\
\hline 247 & $\begin{array}{l}\text { Professor: Gente, interpretação da } \\
\text { complementaridade, tá certo? Voltamos às } \\
\text { discussões que estavam acontecendo agora } \\
\text { pouco, tá? O fóton ora vai se manifestar como } \\
\text { onda, ora como partícula, tá certo? Mais nunca } \\
\text { ao mesmo tempo. Essa é a diferença que a } \\
\text { gente encontra entre os dois. Na dualista } \\
\text { realista o fóton é onda e partícula ao mesmo } \\
\text { tempo. Eu tenho uma partícula com uma onda } \\
\text { associada. Na interpretação da } \\
\text { complementaridade, ora é de um jeito, ora de } \\
\text { outro. E aí, vocês dois na hora que estavam } \\
\text { comentando, né? Fizeram essa discussão. E } \\
\text { aí o arranjo que a gente tem ali, a gente tem } \\
\text { observação como? Como o que? Como onda } \\
\text { e quando a gente põe o detector o que } \\
\text { acontece? Ele ta interpretando como partícula, } \\
\text { deixa de ter interferência. Na hora que a gente } \\
\text { tava fazendo lá a simulação, quando a gente } \\
\text { ta observando a interferência, qual é o } \\
\text { comportamento que eu to eu to vendo ali da } \\
\text { complementaridade? Como onda, certo? } \\
\text { Agora, quando eu ponho o detector lá, o que } \\
\text { acontece? Vai interagir o detector com o fóton } \\
\text { que ta passando. Aquele fóton ali vai ter um } \\
\text { comportamento de partícula e aí ele é } \\
\text { absorvido ali e a gente não tem mais a } \\
\text { interferência. Agora vocês têm que completar } \\
\text { aí o quadro e tentar encaixar essas quatro } \\
\text { afirmações pra cada uma dessas } \\
\text { interpretações. Olha, "precisando de uma nova } \\
\text { lógica". Essa interpretação, essa frase, se } \\
\text { adéqua a qual dessas interpretações? } \\
\text { Ondulatória, a corpuscular, } \\
\text { complementaridade... "Quando o fóton se } \\
\text { divide, quando o fóton decide se e onda ou } \\
\text { partícula, só podemos falar na natureza da luz } \\
\text { depois que a gente fizer a medição." Essa } \\
\text { afirmação é corpuscular, é dualista.. }\end{array}$ & Sintetizar & & \\
\hline 248 & Bruna: É complementaridade. & & & $\begin{array}{l}\text { Levantamento } \\
\text { de hipótese }\end{array}$ \\
\hline
\end{tabular}




\begin{tabular}{|c|c|c|c|c|}
\hline $\mathbf{T}$ & Falas Transcritas & $\begin{array}{l}\text { Propósitos } \\
\text { Epistêmicos }\end{array}$ & $\begin{array}{l}\text { Tipo de } \\
\text { Pergunta }\end{array}$ & $\begin{array}{l}\text { Indicadores } \\
\text { de AC }\end{array}$ \\
\hline 249 & $\begin{array}{l}\text { Professor: Ahn? Não, isso vocês só vão } \\
\text { responder pra mim. No papel vocês vão } \\
\text { colocar só essas questões que tão. Agora } \\
\text { aqui... }\end{array}$ & & & \\
\hline 250 & Beatriz: A segunda é complementaridade. & & & $\begin{array}{l}\text { Levantamento } \\
\text { de hipótese }\end{array}$ \\
\hline 251 & $\begin{array}{l}\text { Professor: Todo mundo concorda que a } \\
\text { segunda é complementaridade? }\end{array}$ & Explorar & $\begin{array}{l}\text { Pergunta } \\
\text { exploratória } \\
\text { sobre o } \\
\text { processo }\end{array}$ & \\
\hline 252 & Felipe: Sim. & & & \\
\hline 253 & $\begin{array}{l}\text { Professor: Eu só posso falar da natureza da } \\
\text { luz depois que eu fizer a medição? }\end{array}$ & & & \\
\hline 254 & Beatriz: Essa é a terceira. & & & $\begin{array}{l}\text { Levantamento } \\
\text { de hipótese }\end{array}$ \\
\hline 255 & Alunos: [Inaudível] & & & \\
\hline 256 & $\begin{array}{l}\text { Professor: "Nunca um meio fóton foi } \\
\text { detectado." Isso é a terceira? }\end{array}$ & & & \\
\hline 257 & Vitor: Ele tá perguntando. & & & \\
\hline 258 & $\begin{array}{l}\text { Professor: Oh, nós temos quatro } \\
\text { interpretações, cada uma dessas afirmações } \\
\text { se refere a uma dessas interpretações. Eu } \\
\text { quero que vocês associem essas frases a } \\
\text { essas interpretações. }\end{array}$ & Problematizar & & \\
\hline 259 & Aline: A última é dualista. & & & $\begin{array}{l}\text { Levantamento } \\
\text { de hipótese }\end{array}$ \\
\hline 260 & Felipe: Meio fóton. & & & $\begin{array}{l}\text { Levantamento } \\
\text { de hipótese }\end{array}$ \\
\hline 261 & Aline: A última é dualista. & & & $\begin{array}{l}\text { Levantamento } \\
\text { de hipótese }\end{array}$ \\
\hline 262 & $\begin{array}{l}\text { Professor: A que se referem cada uma delas, } \\
\text { vamos lá? }\end{array}$ & Problematizar & & \\
\hline 263 & $\begin{array}{l}\text { Lucas: A } 1 \text { é ondulatória. É uma diferente da } \\
\text { outra, professor. }\end{array}$ & & & $\begin{array}{l}\text { Levantamento } \\
\text { de hipótese }\end{array}$ \\
\hline 264 & $\begin{array}{l}\text { Professor: Não, eu quero saber a que se } \\
\text { refere, não to falando que é. }\end{array}$ & Problematizar & & \\
\hline 265 & Lucas: Ah sim. & & & \\
\hline 266 & $\begin{array}{l}\text { Professor: Eu to falando assim a quais } \\
\text { interpretações essas afirmações se referem. }\end{array}$ & Qualificar & & \\
\hline 267 & Lucas: Entendi. & & & \\
\hline 268 & $\begin{array}{l}\text { Professor: Um, dois, três, quatro, certo? Então } \\
\text { a gente tem interpretação... }\end{array}$ & Problematizar & & \\
\hline 269 & Aluno: Interpretação... dualista... & & & $\begin{array}{l}\text { Levantamento } \\
\text { de hipótese }\end{array}$ \\
\hline 270 & $\begin{array}{l}\text { Professor: Quais dessas afirmações dizem } \\
\text { respeito... }\end{array}$ & Problematizar & & \\
\hline 271 & Aline: A última é dualista realista. & & & $\begin{array}{l}\text { Levantamento } \\
\text { de hipótese }\end{array}$ \\
\hline 272 & Professor: A quarta é dualista realista? É isso? & Explorar & & \\
\hline 273 & Aline: $\dot{E}$. & & & Explicação \\
\hline 274 & Alunos: $\dot{E}$ & & & Explicação \\
\hline 275 & $\begin{array}{l}\text { Professor: Mas tem mais alguém aqui que ta } \\
\text { dizendo que a primeira também é. }\end{array}$ & Explorar & & \\
\hline 276 & Bruna: [Inaudível] & & & \\
\hline 277 & $\begin{array}{l}\text { Professor: É... Qual delas fala sobre, né? } \\
\text { Onda e partícula juntas? }\end{array}$ & Problematizar & $\begin{array}{l}\text { Pergunta de } \\
\text { sistematização }\end{array}$ & \\
\hline 278 & Aline: Dualista. & & & $\begin{array}{l}\text { Levantamento } \\
\text { de hipótese }\end{array}$ \\
\hline 279 & $\begin{array}{l}\text { Professor: É, que ele fala que tem então uma } \\
\text { partícula surfando numa onda. Qual que fala } \\
\text { sobre isso? }\end{array}$ & Problematizar & $\begin{array}{l}\text { Pergunta de } \\
\text { sistematização }\end{array}$ & \\
\hline 280 & Alunos: [Inaudível] & & & \\
\hline 281 & Professor: Como é que é? A dois? & Explorar & & \\
\hline
\end{tabular}




\begin{tabular}{|c|c|c|c|c|}
\hline $\mathbf{T}$ & Falas Transcritas & $\begin{array}{l}\text { Propósitos } \\
\text { Epistêmicos }\end{array}$ & $\begin{array}{l}\text { Tipo de } \\
\text { Pergunta }\end{array}$ & $\begin{array}{l}\text { Indicadores } \\
\text { de AC }\end{array}$ \\
\hline 282 & Felipe: A dois é complementaridade. & & & $\begin{array}{l}\text { Levantamento } \\
\text { de hipótese }\end{array}$ \\
\hline 283 & $\begin{array}{l}\text { Alunos: A três é ondulatória e a um é } \\
\text { dualidade. }\end{array}$ & & & $\begin{array}{l}\text { Levantamento } \\
\text { de hipótese }\end{array}$ \\
\hline 284 & $\begin{array}{l}\text { Professor: } \hat{E} \text { isso? } \dot{E} \text { isso, povo? Vamos } \\
\text { conferir? "Nunca um meio fóton foi detectado", } \\
\text { ta certo? Pensando na gente dividir a onda em } \\
\text { duas partes, ta certo? Na teoria corpuscular a } \\
\text { gente não consegue explicar então a gente } \\
\text { precisa de uma lógica nova, não é isso? } \\
\text { Pensando como sendo partícula, que ela é } \\
\text { invisível esse tipo de coisa, então eu preciso } \\
\text { de uma nova lógica pra explicar a partícula, } \\
\text { pra explicar essa interferência, ta? Pra um } \\
\text { único fóton a gente não conseguiu dar } \\
\text { explicação. Onda vazia caminhando, né? } \\
\text { Numa partícula... A partícula caminhando } \\
\text { nessa onda é dualista realista. E esse aqui é } \\
\text { complementar por quê? Porque eu só vou ter } \\
\text { informação da natureza da luz depois de } \\
\text { medir. Quando eu to vendo a luz eu não sei se } \\
\text { ela é onda ou se ela é partícula. Se eu } \\
\text { observo interferência eu to me referindo a } \\
\text { quê? }\end{array}$ & $\begin{array}{l}\text { Problematizar } \\
\text { Explorar }\end{array}$ & $\begin{array}{l}\text { Pergunta de } \\
\text { sistematização }\end{array}$ & \\
\hline 285 & Beatriz: Onda. & & & Explicação \\
\hline 286 & $\begin{array}{l}\text { Professor: } \AA \text { A onda. Se eu observo efeito } \\
\text { fotoelétrico? }\end{array}$ & Problematizar & $\begin{array}{l}\text { Pergunta de } \\
\text { sistematização }\end{array}$ & \\
\hline 287 & Beatriz: Partícula. & & & Explicação \\
\hline 288 & $\begin{array}{l}\begin{array}{l}\text { Bruna: Mas como que ele explica } \\
\text { [inaudível] }\end{array} \\
\text { [i... }\end{array}$ & & & \\
\hline 289 & $\begin{array}{l}\text { Professor: Não explica. O que vai dizer pra } \\
\text { essa interpretação é que eu não sei qual é a } \\
\text { natureza, eu só consigo obter informação } \\
\text { disso depois te der feito a medida. }\end{array}$ & & & \\
\hline 290 & Bruna: Eles não explicam! & & & \\
\hline 291 & $\begin{array}{l}\text { Professor: É. Aí porque se comporta de uma } \\
\text { maneira diferente é um campo de atuação } \\
\text { pra... Pro próximo, né Beatriz Sanches? }\end{array}$ & & & \\
\hline 292 & Alunos: [Inaudível] & & & \\
\hline 293 & $\begin{array}{l}\text { Professor: Vou até mandar um e-mail pro O. lá } \\
\text { dizendo que você já se decidiu, certo? } \\
\text { Pessoal, finalzinho da aula, respondam as } \\
\text { questões, completem os quadros e me } \\
\text { entreguem, certo? }\end{array}$ & & & \\
\hline 294 & Beatriz: O quê? Pra próxima aula? & & & \\
\hline 295 & $\begin{array}{l}\text { Professor: Finalzinho desta aula. É pra acabar } \\
\text { agora, já, nesse instante. }\end{array}$ & & & \\
\hline 296 & Beatriz: Passa as notas. & & & \\
\hline 297 & Karina: Vamos fazer juntos. & & & \\
\hline 298 & Alunos: [Inaudível] & & & \\
\hline 299 & Professor: Agora é a hora de vocês anotarem. & & & \\
\hline 300 & Aluno: e as notas? & & & \\
\hline 301 & $\begin{array}{l}\text { Professor: Vou falando as notas enquanto } \\
\text { isso? Eu não tenho as notas do estudo do } \\
\text { meio ainda. }\end{array}$ & & & \\
\hline 302 & Alunos: [Inaudível] & & & \\
\hline 303 & $\begin{array}{l}\text { Professor: Tem recuperação amanhã, é o } \\
\text { ultimo dia de recuperação amanhã, para } \\
\text { aqueles que estão de recuperação ainda. A } \\
\text { prova de recuperação é amanhã. }\end{array}$ & & & \\
\hline 304 & Alunos: [Inaudível] & & & \\
\hline 305 & $\begin{array}{l}\text { Professor: Eu falo e o que vai acontecer... A } \\
\text { condição pra eu falar é vocês entregarem essa }\end{array}$ & & & \\
\hline
\end{tabular}




\begin{tabular}{|c|l|l|l|l|}
\hline T & \multicolumn{1}{|c|}{ Falas Transcritas } & $\begin{array}{c}\text { Propósitos } \\
\text { Epistêmicos }\end{array}$ & $\begin{array}{c}\text { Tipo de } \\
\text { Pergunta }\end{array}$ & $\begin{array}{c}\text { Indicadores } \\
\text { de AC }\end{array}$ \\
\hline 306 & folha aí e tirar PS, certo? & & & \\
\hline 307 & $\begin{array}{l}\text { Lucas: Ta bom. } \\
\text { Professor: Dois, quatro, seis... Olha pessoal, a } \\
\text { comação que eu consigo passar pra vocês é } \\
\text { atividades do doze conceitos, ta? Faltam as ado do meio ainda pra passar } \\
\text { pra vocês. }\end{array}$ & & & \\
\hline
\end{tabular}

